Historic, Archive Document

Do not assume content reflects current scientific knowledge, policies, or practices. 


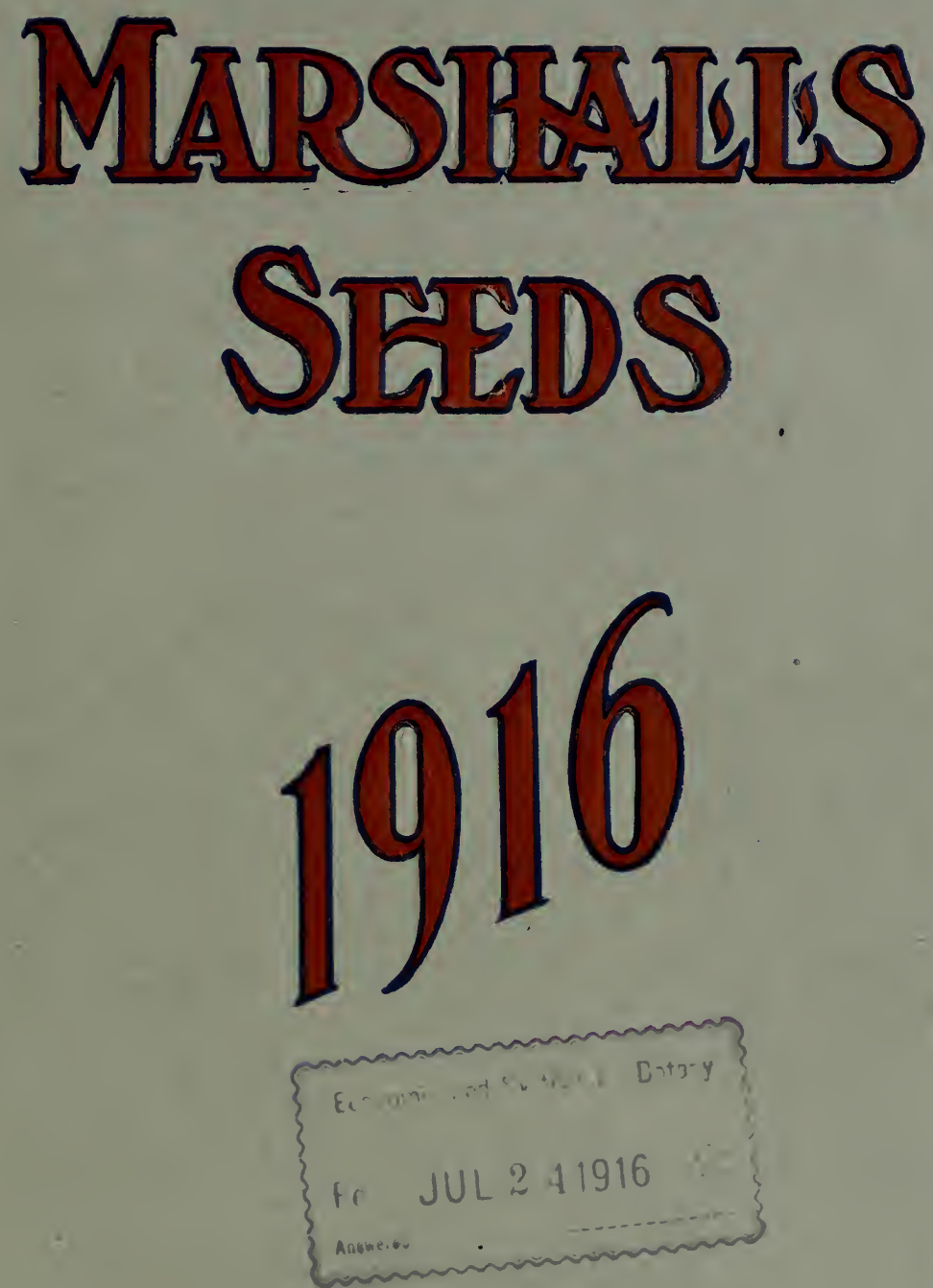

\section{W. E.MARSHALL \& CO. 166 WEST 23RD STREET NEW YORK}




\section{TWELFTH ANNIVERSARY ANNOUNCEMENT}

WELVE years ago we commenced business at 146 West 23d Street and after 1 nine years moved to our present more commodious quarters at 166 West 23rd Street, to enable us to handle our increased business.

We thank our numerous patrons and friends for their continued confidence in our goods, which has enabled us to be proul of their patronage, and we hope to still maintain the standard and quality of our bulbs in the future as in the past.

Our patrons will always find courteous treatment from our fellow workers who have so greatly aided us in the expansion of our business.

January, 1916.

W. E. MARSHALL, A. E. WHEELER.

\section{ORDER EARLY.}

We request our customers to order as early as possible on receipt of catalogue. We endeavor to ship all orders immediately on receipt, but during the busy season it is almost impossible; hence, the importance of ordering early.

\section{PARCELS POST.}

We deliver free by Parcels Post all seeds, except Beans, Corn, Peas, Farm Seeds or Clovers. If these are wanted by mail please add the cost of postage at zone rates.

Within a radius of 100 miles from New York City we deliver free any order entirely composed of Seeds or Bulbs amounting to two dollars or over, providing cash accompanies the order. pound.

We deliver free by mail all flower and vegetable seeds by the packet, ounce and

Fertilizers, insecticides, sundries, trees and plants are at all times excluded from free delivery.

No charge for packing or delivery to railroad station, steamer or express office

\section{GARDENERS AND FARMERS.}

Parties requiring the services of reliable men, married or single, should consult with us, as we have the names of a number on our register, thoroughly experienced in every branch of the business. We have a large acquaintance among gardeners in this vicinity, and it is seldom that any one who applies to us fails of getting the right party. No fee.

We beg to call the attention of our patrons to our complete catalogue (mailed free upon request) containing all kinds of

\section{ROSES, FRUIT TREES, SHRUBS, EVERGREENS, DECIDUOUS TREES AND HARDY PLANTS.}

\section{POULTRY SUPPLIES.}

We issue a complete Catalogue of Poultry Supplies, which will be mailed free on request.

\section{W. E. MARSHALL \& CO.}

TELEPHONE 3288 CHELSEA
166 WEST 23rd STREET, NEW YORK LOCATION OF OUR STORE.

Our store, No. 166 West 23rd Street, is situated near Seventh Avenue, hetween Sixth and Seventh Avenues. 


\title{
SPECIAL NOTICE.
}

Owing to the disastrous war in Europe a great many of the European Seed crops have not been harvested or are prohibited from being exported. At the date of going to press with this Catalogue, we are without final reports from our growers so we cannot guarantee deliveries on some varieties of seeds, but we will endeavour to fill all orders to the best advantage.

Prices of Seeds and other supplies are subject to changes with conditions of markets.

W. E. MARSHALL \& Co.

\section{SPECIALTIES AND EXHIBITION STRAINS IN VEGETABLES}

\author{
BEET, Marshall's Exhibition.
}

A selected strain of the Globe type, roots medium size, symetrical in form, and unrivalled for the exhibition or table use. Pkt. 10 cts. oz. 25 cts. $1 / 4$ lb., 75 cts.

\section{BRUSSELS SPROUTS, \\ Marshall's Exhibition.}

Produces an abundant crop of large solid sprouts, delicious in flavor. For exhibition purposes this fine variety is unequalled and it cannot be surpassed for general cultivation. Pkt., 10 cts.; oz., 50 cts.
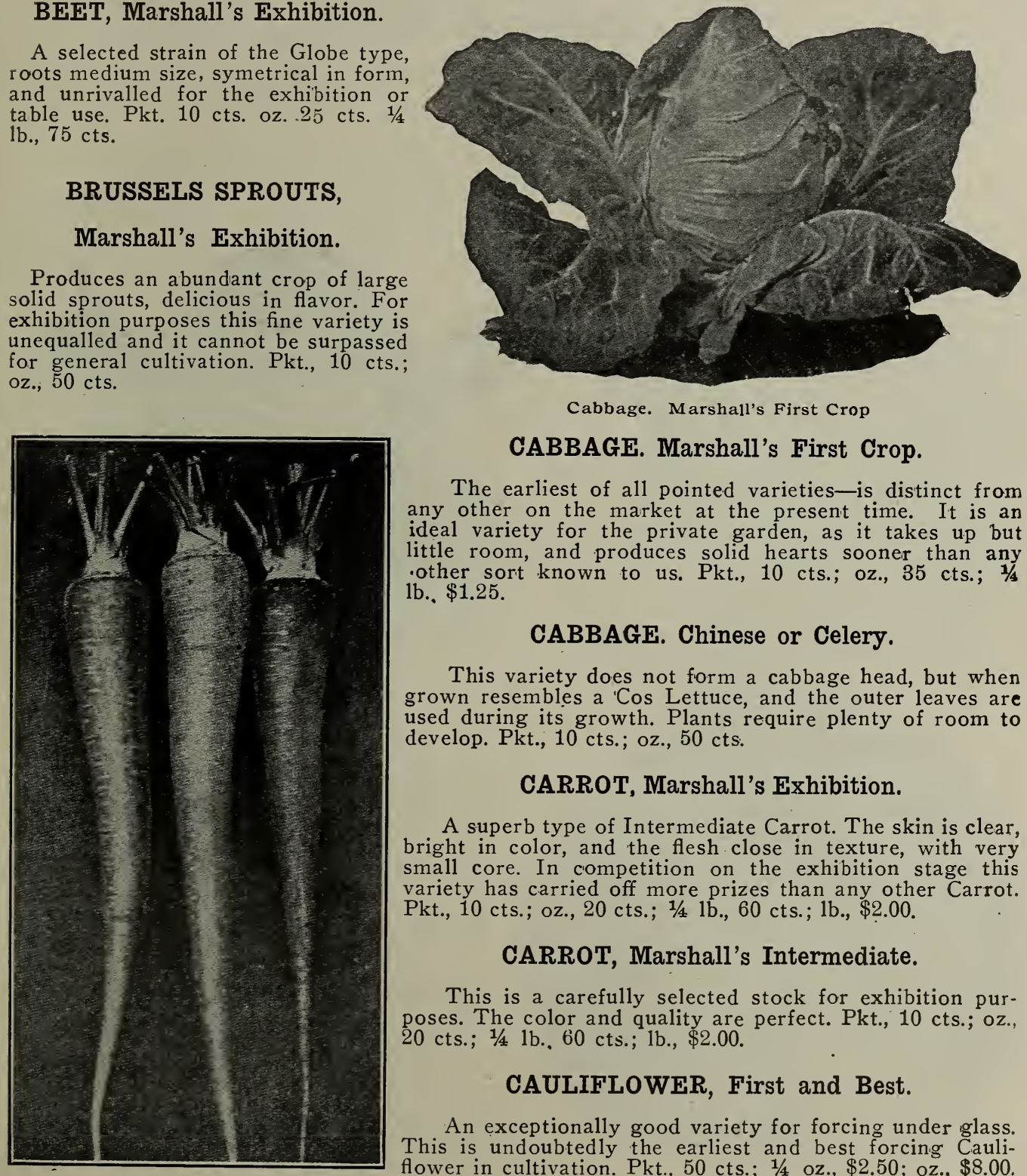

CABBAGE. Marshall's First Crop.

The earliest of all pointed varieties-is distinct from any other on the market at the present time. It is an ideal variety for the private garden, as it takes up but little room, and produces solid hearts sooner than any -other sort known to us. Pkt., $10 \mathrm{cts}$; oz., $35 \mathrm{cts}$; $1 / 4$ lb. $\$ 1.25$.

\section{CABBAGE. Chinese or Celery.}

This variety does not form a cabbage head, but when grown resembles a 'Cos Lettuce, and the outer leaves are used during its growth. Plants require plenty of room to develop. Pkt., 10 cts.; oz., 50 cts.

\section{CARROT, Marshall's Exhibition.}

A superb type of Intermediate Carrot. The skin is clear, bright in color, and the flesh close in texture, with very small core. In competition on the exhibition stage this variety has carried off more prizes than any other Carrot. Pkt., 10 cts.; oz., 20 cts.; $1 / 4$ lb., 60 cts.; 1b., $\$ 2.00$.

\section{CARROT, Marshall's Intermediate.}

This is a carefully selected stock for exhibition purposes. The color and quality are perfect. Pkt., $10 \mathrm{cts}$; oz., 20 cts.; $1 / 4$ lb. 60 cts.; lb., $\$ 2.00$.

\section{CAULIFLOWER, First and Best.}

An exceptionally good variety for forcing under glass. This is undoubtedly the earliest and best forcing Cauliflower in cultivation. Pkt., 50 cts.; $1 / 4$ oz., $\$ 2.50$; oz., $\$ 8.00$. 


\section{SPECIALTIES IN VEGE.TABLES - Continued}

SWEET CORN. Early Mayflower.

This is a week or ten days earlier than White Cory. The ears are long and well filled from tip to butt, with white kernels. It is wery tender and fine flavored. Pkt., $10 \mathrm{cts}$; pint. 20 cts.; quart, 40 cts.; peck, $\$ 2.50$.

\section{SWEET CORN. Howling Mob.}

An early variety of special merit. The ears are much larger and sweeter than Early Cory. Grains are white and delicious flavor. For an early variety we recommend this highly. Pkt., 10 cts.; pint, 15 cts.; quart, 30 cts.; peck, $\$ 2.00$.

\section{KALE. Marshall's Exhibition Curled.}

This is really the handsomest Kale that has ever come under our notice, and is entirely distinct from other strains. The closely curled, handsome leaves are most attractive. A fine exhibition plant of medium height. Pkt., $10 \mathrm{cts}$; oz., 25 cts.

\section{LEEK, Marshall's Giant.}

The largest and best Leek for exhibition. Highly recommended as the choicest variety in cultivation, of a mild delicious flavor. $\mathrm{Pkt}$. $10 \mathrm{cts}$; oz., $40 \mathrm{cts}$.

\section{LETTUCE. Marshall's Matchless.}

This wonderful head lettuce produces large, extremely solid, compact heads, very sweet, tender and fine shipping and eating qualities. We have only a limited supply of seeds and offer them in packets only. Per pkt. 25 cts.

\section{LETTUCE, Eclipse Cos.}

A perfectly distinct variety. It is the dwarfest Cos Lettuce, and produces a firm crisp heart quicker than other sorts, and is the most selffolding variety. Pkt., 10 cts.; oz., 40 cts.

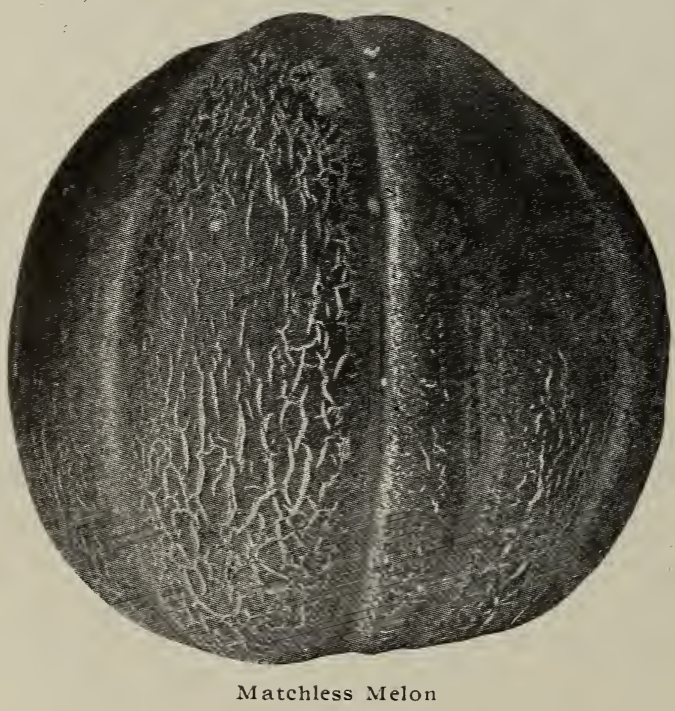

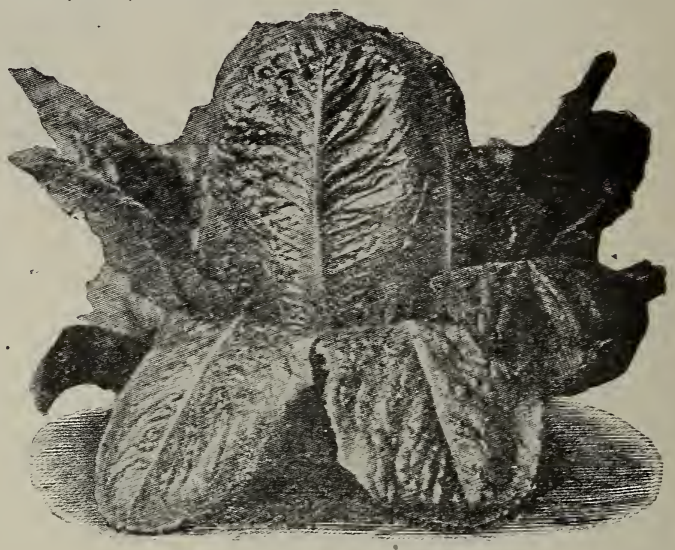

Eclipse Cos Lettuce

\section{LETTUCE, Wayahead.}

This is the earliest and surest heading Lettuce grown. It is earlier and larger than May King, more tightly folded and with smaller amount of outer foliage. The leaves are light green and heads blanched to a rich yellow tint. Pkt., 10 cts.; oz., 30 cts.; $1 / 4$ lb., 75 cts.

\section{MUSK MELON. Marshall's Matchless.}

This Musk Melon is the largest and most luscious Melon we have seen. The fruits average from 15 to 20 pounds in weight, are wonderfully uniform in shape, distinctively ribbed and netted. The flesh is an orangescarlet color, very thick, edible to the rind and of a luscious flower; the seed cavity is very small for so large a melon. Plants produce from five to eight handsome fruits and the vines are remarkably healthy and vigorous. Per pkt., 15 cts. 


\section{SPECIALTIES IN VEGETABLES-Continued.}

\section{ONION. Giant Gibraltar.}

This Onion is similar in appearance to the Prizetaker but is lighter in color and much larger in size. From seed sown in January it will produce huge bulbs over one and a half pounds in weight. Pkt., 10 cts.; $1 / 2$ oz., 15 cts.; oz., 30 cts.; 1/4 1b., $\$ 1.00$.

\section{ONION. Invincible Giant.}

The latest and most important novelty in exhibition Onions. This is not an improved strain of Ailsa Craig, but grown under the same conditions, produces bulbs one-third larger. Pale yellow in color. The seeds we offer are carefully selected for us b.y an English-grower. Pkt., 25 cts.; $1 / 4$ oz., 50 cts.; oz., $\$ 1.50$.

\section{ONION, Ailsa Craig.}

The skin is a pale straw color, and oval in shape. Excellent for exhibition purposes. The seed we offer is imported and grown from a selected strain. Pkt., $10 \mathrm{cts}$.; $1 / 2$ oz., $25 \mathrm{cts}$.; oz., 50 cts.

\section{ONION, Cranston's Excelsior.}

This is the leading English Exhibition variety, and well deserves its popularity. It is very large and handsome, inclined to globular in shape, and of 'beautiful straw color. Pkt., 10 cts.; $1 / 2$ oz., 25 cts.; oz., 50 cts.

\section{PEA, Kelways Beauty.}

The dark green pods, are larger, longer and more even in size than Gradus and contain fine deep green peas. It is very hardy and can be sown early; height 3 feet. $1 / 2$ pint 15 cts.; pint 30 cts.; qt. 60 cts.

\section{PEA. Marshall's Warrior.}

Height 5 feet, main crop, very productive, pods well filled, of deep green color, flavor superb. $1 / 2$ pint 25 cts.; pt. 50 cts.; qt. $\$ 1.00$.

\section{PEA. Senator.}

One of the best main crop curved podded varieties. Height 3 feet. $1 / 2$ pint 20 cts.; pt. 40 cts.; qt. $75 \mathrm{cts}$.

\section{PEA. The Leader.}

This is a selection of the rounder seeds of Gradus, and while retaining the earliness of that variety, the pods are larger and produce in great er abundance. Height, 3 feet. Per pint, 30 cts.; quart, 60 cts.; $1 / 2$ peck $\$ 2.25$.

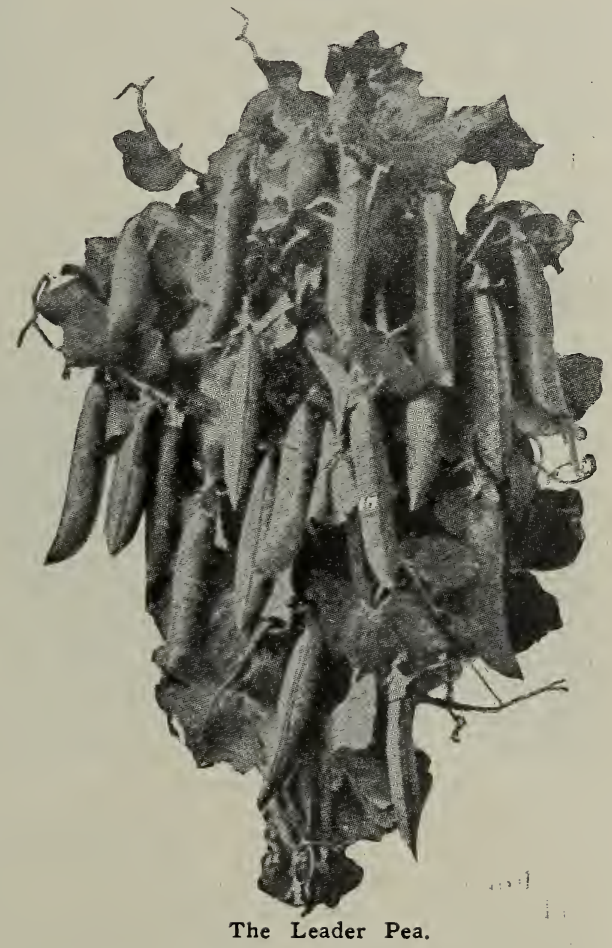

\section{PARSLEY. Marshall's Crested Gem.}

The dwarf compact habit of the plant and the fineness of the closely cut foliage are unsurpassable. Pkt., 10 cts.; oz:; 50 cts.; 1/4 lb., $\$ 1.50$.

\section{PARSNIP. Marshall's Marrow.}

This is a choice selection of the English Marrow wariety, grown in England specially for us. The roots are clean and white of the finest quality. As an exhibition variety this has na equal. Pkt., 10 cts.; oz., 20 cts.; 1/4 lb., 50 cts.

\section{PEPPER. Marshall's Perfection.}

Very smooth and uniform in shape; color when ripe a beautiful scarlet red; quality very sweet and delicious. Pkt. $10 \mathrm{cts}$; oz., $60 \mathrm{cts}$. 


\section{SPECIALTIES IN VEGETABLES--Continued.}

\section{POTATO. Norcross.}

This grand Potato is grown with great success by a Jersey grower from whom we have procured some selected seed.

It is a splendid smootn, white skinned, shallow eyed variety. A wonderful cropper, cooks very mealy and is a fine keeper.

Peck, 70 cts.; Bushel, \$2.50.; Bbl. $\$ 5.00$

\section{RADISH. Marshall's Perfection.}

As will be seen from the cut, this radish is a very attractive variety. The white tip extends nearly half way up the root, and the brilliant red color of the top shows up in strong contrast.

Pkt., 5 cts.; oz., 10 cts.; 1/4 1b., 30 cts., lb., $\$ 1.00$.

\section{SQUASH. English Vegetable Marrows.}

Long Green Bush. Fruits long pale green; rich flavor. Pkt., 10 cts.; oz., 30 cts.

Long White Bush. 'Creamy white; very prolific. Pkt., 10 cts.; oz., 30 cts.

Long Cream. Very long, pale cream color trailing sort. Pkt., 10 cts.; oz., 30 cts.

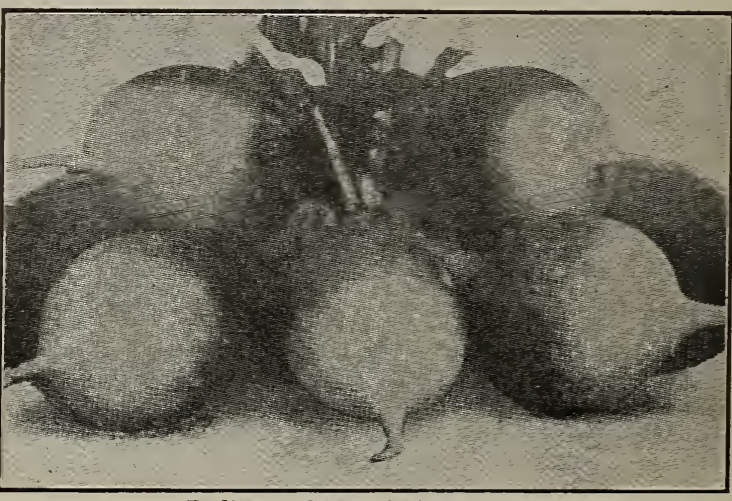

Radish. Marshall's Perfection.

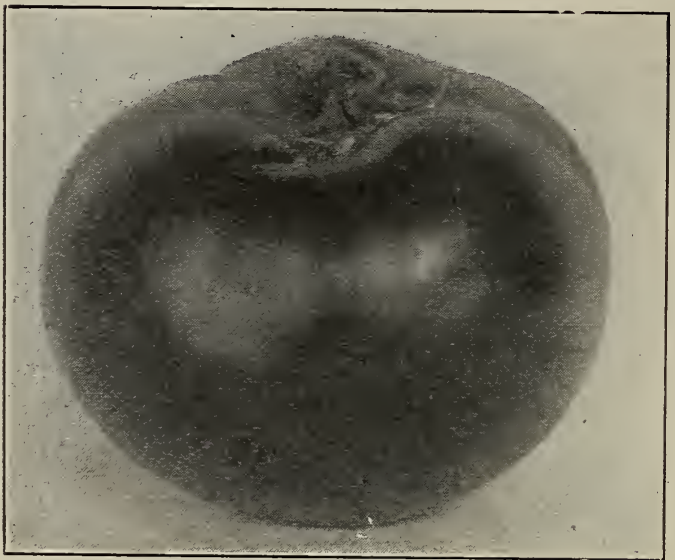

\section{TOMATO. Marshall's National.}

This grand new Tomato is the result of 10 years selecting by a Tomato expert. It has a perfect high crown, entirely free from core, ripens evenly, does not crack and a brilliant scarlet color. The fruit average about 6 ounces and often have ten in a cluster of a mild sweet flavor. It is very early and will mature ripe fruit in 30 days outside from strong plants. Pkt., 25 cts.

National Tomato.

\section{TOMATO, Marshall's Prolific.}

For forcing we can strongly recommend it as being the best variety, as it sets very freely and is an exceptionally heavy copper. For outside planting it is the earliest variety grown, an enormous cropper, of medium size, producing as many as 30 Tomatoes on a truss. The fruit, is a bright scarlet color perfectly smooth, flesh solid, and contains very few seeds. Packet, 25 cents.

\section{TOMATO. Buck's Tresco.}

The fruits are round, bright red, of moderate size and excellent quality. The average truss is about 5 pounds and plants will carry five or six large trusses. It sets very freely and is an immense cropper, yielding heavy bunches at short intervals all over the plant.

Sealed packets, 25 cents each.

\section{TURNIP, Selected White Milan.}

The Milan Turnips are among the earliest in cultivation; roots flat; medium size, quite smooth. Fine for exhibition or family use. Pkt., 5 cts.; oz., $15 \mathrm{cts}$; $1 / 4 \mathrm{lb}$., $30 \mathrm{cts}$.

It gives us great pleasure to announce that Vegetables grown from our Seeds secured many prizes at the shows in this vicinity and were admired by all who saw them.

Remember to order our specialties when making up your list for 1916 and you will be amongst the prize winners. 


\title{
Novelties and Specialties in Flower Seeds
}

\author{
ANTIRRHINIUM. Matchless Yellow.
}

A selected strain saved from flowers grown under glass. Pkt., 25 cts.

\section{ANTIRRHINIUM. Matchless White.}

This is a selected strain saved from flowers grown under glass and we recommend it for growing in greenhouses. Pkt., $25 \mathrm{cts}$.

\section{ANTIRRHINIUIM. Silver Pink.}

This large flowering variety has been admired by all who have seen it at the various exhibition. It is the best variety for greenhouse planting. For cut flowers it has no equal, its long racimes of flowers being especially adapted for decorating. Pkt., 50 cts.

\section{ASTER. Autumn Glory.}

Color pure sea-shell pink. Its most distinctive characteristic is that it is later than any other variety. Pkt., 25 cts.

\section{ASTER. Marshall's King.}

The habit and season is similar to the Branching type. The form of the flower is distinct from any other variety, the petals being folded lengthwise, giving them a bold and striking appearance.

Crimson King. A rich dark crimson.

Pink King. A beautiful shade.

Violet King. Soft violet purple.

White King. Pure white.
Per packet $10 \mathrm{cts}$. Collection of 6 colors for $50 \mathrm{cts}$.

Lavender King. A beautiful deep lavenders.

Rose King. A brilliant rose.

\section{ASTER. Triumph Comet.}

A magnificent new class of mid-season Asters, with extra long stems, and large fluffy, full double flowers of the finest type. A great improvement over any Upright 'Comet heretofore offered, in size or plant, length of stem, and size and perfection of flower.

Separate colors: White. Shell Pink, Lavender, Rose, Purple, or Mixed. Each, per pkt., 10 cts.; $1 / 4$ oz., $\$ 1.00$.

\section{ASTER. Single Japanese.}

Two new single Asters which have large star-shaped flowers, resembling those of the single Japanese Chrysanthemum. Of branching habit, and very free flowering. Useful as a cut flower and can be used to advantage for late summer bedding.

Separate colors. Delicate Rose and White. Each, per pkt., 25 cts.

\section{AQUILEGIA. Marshall's Matchless Long-Spurred Hybrids}

A grand selection of colors saved from the choicest varieties. Fine for cutting or hardy borders. Pkt., $25 \mathrm{cts}$.

\section{CANDYTUFT. The Pearl.}

A continuous and rigorous selection has resulted in what we consider the finest type of White Candy-tuft in existence. The plants should be allowed plenty of room for development. Pkt., 10 cts.; $1 / 2$ oz., 50 cts.

\section{CENTAUREA, Moschata Rosea.}

A charming new Sweet Sultan growing about 3 feet. The color of the flowers in opening is a very delicate rosy-white, changing to a charming rosy-pink later. Fine for cutting. Pkt., 15 cts. 


\section{NOVELTIES and SPECIALTIES IN FLOWER SEEDS-Continued}

\section{CELOSIA. Childsi.}

Plants grow two to three feet high and bloom from June till frost, the flowers are similar to balls of wool and a deep crimson-scarlet color, which do not fade until hit by frost. A valuable bedding plant owing to its continuous blooming season. Pkt., $25 \mathrm{cts}, 1 / 16 \mathrm{oz}$. $\$ 2.00$.

\section{CINERARIA. Matchless Prize Mixed.}

This superb strain of Cinerarias are distinguished for their splendid range of colors, which include blue crimson, pink and velvet, the markings are distinct and the form of the flower is fine and symmetrical, the plants are of excellent habit. Pkt., 50 cts.

\section{CYCLAMEN. Eileen Low.}

The color is a lovely shade of pink, but the great attraction lies in the distinct blush white crest on each petal, which on account of the great contrast gives it an attractive and unique appearance. Pkt., 50 cts.

\section{CYCLAMEN. St. George.}

A variety with beautiful marbled foliage. Flowers are of a pale salmon color which contrast well with the foliage of the plant. Pkt., 50 cts.

\section{DELFHINIUM. Marshall's Matchless Hybrids.}

A very beautiful strain with large handsome flower spikes, including the best of the new double and single named varieties. Pkt., 25 cts.

\section{GAILLARDIA. Marshall's Matchless Hybrids.}

A grand new improved strain. Enormousflowers and very stout habit,including a grand varieties of colors. Pkt., $25 \mathrm{cts}$.

\section{GLOXINIA. Marshall's Matchless.}

This strain is saved from the very choicest erect flowering varieties in cultivation. The flowers are of gigantic proportions brilliant in color and beautifully marked. Pkt., 50 cts.

\section{MORNING GLORY. Double "Snow Fairy".}

This new Morning Glory grows as vigorously as the ordinary variety, the flowers are similar to tassels and snow white in color, measuring $2 \frac{1}{2}$ inches in depth and diameter. Pkt., 15 cts.

\section{MIGNONETTE, "Majesty."}

This is a very select strain of greenhouse grown Mignonette, producing spikes of very large size. The seed we offer is grown from selccted spikes especially for us by a large flower grower. Pkt., 50 cts.

\section{NIGELLA. Miss Jekyll. Pure White.}

A new pure white Nigella, which stands out boldly aginst the green foliage, and a pretty contrast to the sky blue of the original variety. Valuable for borders and cutting. Pkt., $10 \mathrm{cts}$.; $1 / 4 \mathrm{oz}$., 75 cts.

\section{PANSY, Marshall's Matchless Mixture.}

These consist of all the newest named varieties in mixture, and include selections of Giant Cassiers, Bugnots, Giant English, Odiers, etc. Pkt., 25 cts.; $1 / 8$ oz., $\$ 1.25 ;$ oz., $\$ 8.00$.

\section{PANSY. Princess.}

A class of Pansy which by its erect habit marks itself as an entirely new type. The stalks are unusually firm and strong and rise vertically from the root. The flowers show an extensive range of colors. Pkt., 25 cts.

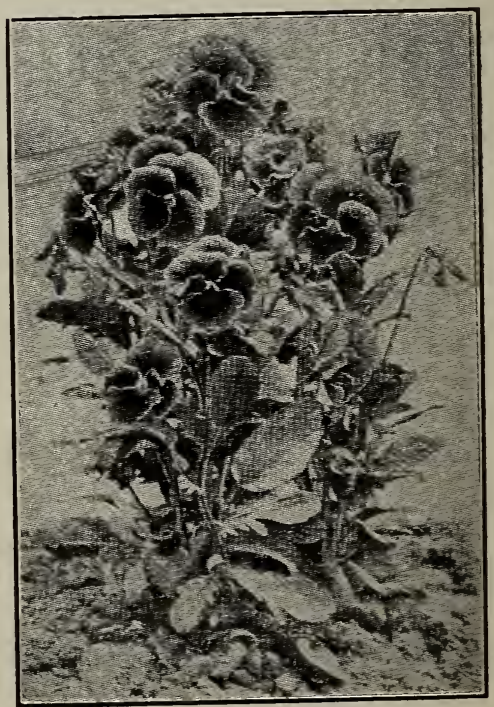

Pansy. Princess 
NOVELTIES and SPECIALTIES IN FLOWER SEEDS-Continued PETUNIA. New Balcony.

These three new varieties with medium-sized flowers of Petunias, are specially adapted for hanging baskets, window boxes and porches. Pkt., each, Dark Red, Rose and White, 25 cts.

\section{PETUNIA. Fimbriata Hybrida.}

Superb Large Flowered Single.

A selected strain of very large flowers, beautifully fringed, deep throated and of various and brilliant colors. Pkt. 25 cts.

\section{POPPY. Oriental White.}

A most distinct break that yet been made in Oriental Poppies, it being a pure satiny white with a bold crimson blotch at the base of each petal. Pkt., 25 cts.

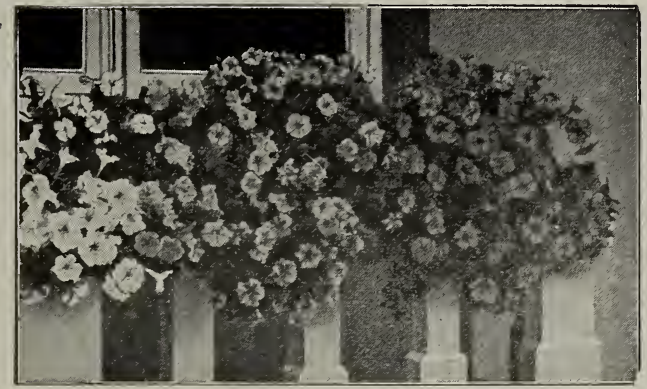

Petunia New Balcony

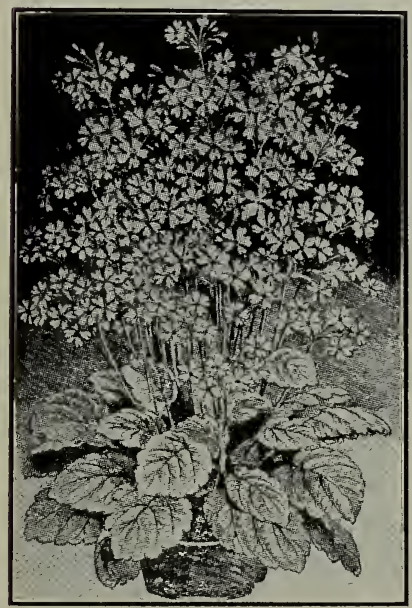

Primula Malacoides

\section{PRIMULA. Forbesii “'Ruby”.}

A charming variety of the Baby Primrose, bearing numerous small deep ruby red flowers with a golden yellow eye. Pkt., $25 \mathrm{cts}$

\section{PRIMULA. Malacoides.}

This sterling novelty is known as the "Giant Baby Primrose," is well worthy of culture. It makes a handsome pot plant and is a profuse bloomer. Fine for decorative purposes.

Separate colors. Lilac. Rose and White. Each per pkt. 25 cts.

\section{PRIMULA. Sinensis Fimbriata Superb.}

Our strain of Primulas has been the greatest surprise to some af the most critical florists and gardeners. The seed is grown by a specialist in England, who raises nothing but Primulas and who is renowned for having the finest Primulas in the old country.

Separate colors. Pure White, Pink Beauty, Deep Blue and Chiswick Red, each. Pkt., 50 cts.

Finest Mixed, all colors. Pkt., 50 cts.

\section{SALVIA. Ostrich Plume.}

The habit of the bush resem'bles the Splendens type producing a bush well covered with beautiful plumes of bright scarlet flowers. It is as hardy as the other Salvias and a valuable plant for bedding purposes. Pkt. 25 cts.

\section{SCHIZANTHUS GRANDIFLORUS MAXIMUS.}

\section{Dr. Badger's Hybrids.}

The plants of this fine variety are more robust and the blooms much larger than any other variety, They grow about two feet high and the flowers measure $1 \frac{1 / 2}{2}$ inches across.

The foliage is fern like, bright green, very handsome, and covered with a beautiful range of colors. Pkt. $50 \mathrm{cts}$.

\section{STOCKS. Ten-Week.}

\section{Marshall's Giant Perfection.}

An extra fine strain, which has been carefully selected from the choicestflowers. We can recommend this strain with the greatest confidence as being the best ever offered. The plants attain a height of 2 feet, and are of handsome pyramidal form, with a branching habit.

We offer the following colors: Chamois Rose, Dark Blue, Crimson. Flesh Color, Light Blue, Pure White, Rose, Scarlet and Yellow.

Separate colors. Pkt., 15 cts.; 1/8 oz., $\$ 1.00$.

Mixed all colors. Pkt., 10 cts.; $1 / 8$ oz, 75 cts.

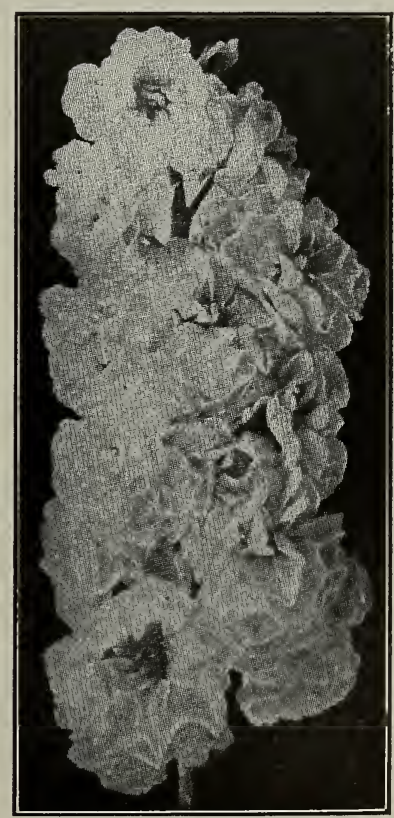

Stock. Perfection 


\section{NOVELTIES and SPECIALTIES IN FLOWER SEEDS-Continued}

STOCKS. Marshall's East Lothian.

These are carefully saved from selected flowers. Valuable for growing in pots or benches tor winter flowering. $\$ 1.50$

Separate colors. Crimson, Purple, Rose, Scarlet and White. Each, per pkt., 25 cts.; 1/8 oz.,

\section{NEW SPENCER SWEET PEAS.}

\section{Fiery Cross.}

The color is a fire-red or scarlet, without any shading. It does not scorch or burn even during extended periods of intense sunshine. The beautifully waved and fluted flowers are borne freely in threes and fours, well placed on long stout stems. Pkt., 25 cts.

\section{Hilary Christy.}

Standard salmon-orange edged with fiery orange-scarlet; wings rosy salmon; Very decorative, strong grower, good sized flowers and fine form. Pkt., 25 cts.

\section{Jean Ireland.}

A large flower of great refinement. The color is creamy-buff, the broad standard and wings being beautifully edged and shaded with carmine-rose. A fine free grower and gives four bloom sprays on long stems. Pkt., 50 cts.

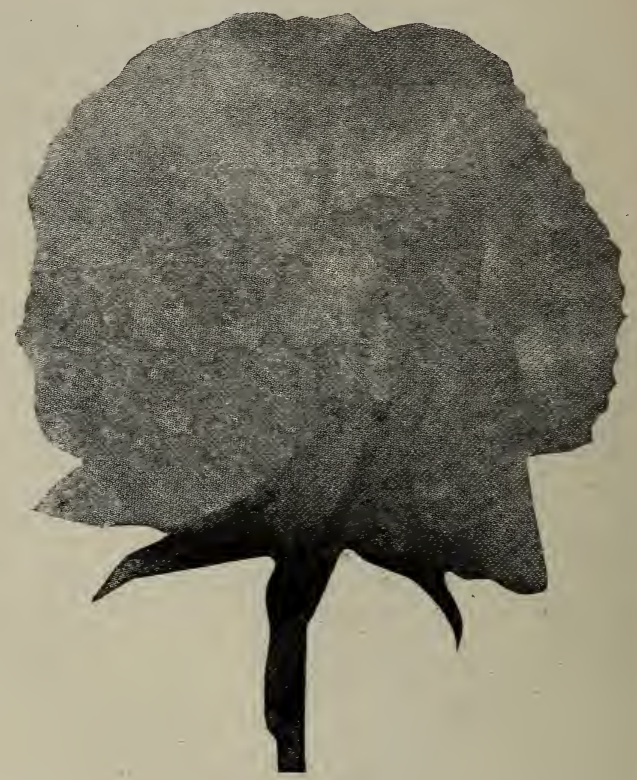

The President.

The flowers are of largest size, carried on long stiff stems, usually in fours, beautifully waved. Color a wonderfully "orilliant glowing scarlet. Pkt., 25 cts.

\section{Lavender George Herbert.}

Very large flowered lavender, long'stems usually with four flowers on each. Pkt., $10 \mathrm{cts}$; oz., 50 cts.; $1 / 4$ lb., $\$ 1.50$.

\section{Florence Nightingale Spencer.}

A beautiful clear lavender. Very large flowers borne on long stems. Pkt., 10 cts.; oz., 50 cts., $1 / 4$ lb., $\$ 1.50$.

\section{ZINNIA. Elegans Grandiflora Robusta.}

We are able to offer distinct colors of these Giant Zinnias, which have been carefully selected. The plants are extremely robust habit and produce flowers measuring 5 to 6 inches across with 300 petals and upwards.

Separate Colors. White, purple, crimson, scarlet, yellow, and rose. Pkt., $10 \mathrm{cts}$. Collection 6 colors for 50 cts.; per oz., 60 cts.

Matchless Mixed. All colors. Pkt., 10 cts., oz., 50 cts

We shall be pleased to supply any other Novelties not offered in our list at advertised prices.

\section{NEW ORCHID COLORED SWAINSONIA}

This beautiful new orchid colored Swainsonia is a very free grower, producing larger spikes of flowers than the old Alba and Roses types.

Fine strong plants, spring delivery from $21 / 4$ in pots. Each 75 cts.; Doz., $\$ 7.50 ; 100, \$ 50.00^{\circ}$

\section{BEGONIA. Mrs. J. E. Peterson}

This new Begonia is the same type as Lorraine. Beautiful carmine-rose flowers, very pro. fuse bloomer, an excellent keeper. The foliage is smaller than Glory of Cincinnati and bronze color.

Plants from $2 \frac{1}{2}$ inch. pots. Each 50 cts. doz. $\$ 5.00 ; 100, \$ 40.00$. 


\section{NOVELTIES IN GLLADIOLUS}

Ruffled Varieties. Kunderdi Types. The following varieties are selections from A. E. Kunderd's stock and comprise a grand variety of his improved strains.

Cherry King. Bright rich cherry color, deeper throat, Very beautifiu ........... Each Dozen

Gov. Hanley. Tall, showy, early rich cardinal red, with deeper throat. ........... 0.101 .00

Ida Van. A most beautiful deep salmon red, or flaming orange pink. . . . . . . $0.10 \quad 1.00$

Myrtle. Tender and delicate rose pink. A beautiful shade. ................... .20 2.00

Pride of Goshen. A Giant Kunderdi Glory, of a salmon or flesh pink. . . . . . . . . $15 \quad 1.50$

Orange Glory. Grand orange colored, with beautiful lighter throat. . . . . . . . ... $\quad .50 \quad 5.00$

Red Amarillas. A most gorgeous and showy red......................... .20 2.00

Red, White and Gold. A beautiful combination of colors. . . . . . . . . . . . . . $50 \quad 5.00$

Summer Beauty. A very choice and distinct pink. Tall grower. . . . . . . . . . . .20 2.00

White Glory. A gorgeous pure white, with beautiful Iris blue throat. . . . . . . . . $50 \quad 5.00$

$\begin{array}{lllll}\text { Special Mixture. A great variety of shades and ruffled sorts. Per } 100, \$ 4.00 \ldots \ldots . & .10 & .60\end{array}$

\section{DECORATIVE DAHLIAS.}

John Wanamaker. The color is an exquisite shade of rose lake or orchid pink. Very long stems and branching habit. Each. $\$ 1.00$; doz., $\$ 10.00$

J. K. Alexander. The color is a royal shade of clear, rich, violet-purple, which deepens to an exquisite deep purple. The gigantic flowers are borne, on long wirely stems, well above the foliage. Each, $\$ 2.00$; doz., $\$ 20.00$.

J. M. Goodrich. A beautiful salmon pink, each petal effectively tipped primrose-yellow. Very large flowers with long stems. Each $\$ 1.00$; doz. $\$ 10.00$.

Mme. Marze. A gigantic new pure white variety. Each 75 cts., Doz., $\$ 7.50$.

\section{NEW CACTUS DAHLIAS.}

Duchess of Marlboro. Color a beautiful tint of solferino backed by a golden suffusion at the base of the petals. Very free flowering. Each $\$ 1.00$; dozen, $\$ 10.00$.

Empress. A huge incurved flower. Color a purplish-crimson, with white at the base of the petals. Each, 75 cts.; doz., $\$ 7.50$.

Kalif. A truly majestic flower of perfect Cactus form, color a pure scarlet. Each $\$ 1.00$; doz., $\$ 10.00$.

Thais. A pure white with a soft mauve suffusion over the petals. Broad petals, loosely arranged. Each, 75 cts.; Doz., $\$ 7.50$.

Walkure. Very large flowers, sulphur-yellow, deepening to a luminous golden-yellow at the center. Each, $\$ 1.00$; ; doz., $\$ 10.00$.

\section{A C H I I E N E S.}

Profuse blooming tender perennials for gr eenhouse or conservatory decoration during summer. The colors comprise white, shades of lilac, mauve and red.

Five named varieties. Each, 10 ists.; dozen, $\$ 1.00 ; 100, \$ 6.00$.

\section{NEW AMIARYLLIS HYBRIDS.}

Hippeastrum, Veitch's and Ker's New Hybrids. The finest race of Amaryllis in cultivation; exceeding in the size and fine form of their flowers, as well as in the diversity of colors and markings, all former hybrids. The segments are of nearly uniform size, giving the flowers a regular trumpet form.

Collection of 12 varieties, largest bulbs, one of each for $\$ 15.00$.

\section{NOVELTIES IN CANNAS.}

Firebird. This is the very best red flowered, green leaved Canna. The flowers are borne in immensi trusses, on all stalks above the leaves. The petals measures $2 \frac{1}{2}$ inches across and the colo1 is a clear scarlet without any streaks, spots or blotches. Each, 50 cts.; doz, $\$ 5.00$.

Mrs. A. F. Conard. One of the most distinct varieties of recent introduction. Its salmon-pink flowers are of largest size, abundantly furnished on erect stems, Foliage green. Height 4 feet. Dozen, $\$ 1.00 ; 100, \$ 7.00$. 


\section{NOVELTY CHRYSANTHEMUMS.}

Alex. Guttman. A grand new, early lavander pink, the best early variety. Each, 50 cts.; dozen $\$ 5.00$.

Artisa. White with a slightly creamy tint in the depths. Very large flower and dwarf habit. Each, $\$ 1.50$; doz., $\$ 15.00$.

Autumn Splendour. Large full flowers of a golden pink or Autumn tint color. Each, 75 cts.; doz. $\$ 7.50$.

Elvia Schoville. A pure white sport of Wells' Late Pink. A fine exhibition variety. Each 50 cts.; doz., $\$ 5.00$.

White Doty. A pure white sport of Lilian Doty. Each, 50 cts.; doz. $\$ 5.00$.

Yellow William Turner. It is identical to the parent Wm. Turner except in color. Each, $\$ 2.00$; doz., $\$ 20.00$.

\section{EXHIBITION CHRYSANTHEIMUMS.}

The following are a selection of the leading varieties seen at the Fall Shows on exhibition, Cheftain or "Ivy Gay." A fine incurved pink of perfect shape.

Daily Mail. A grand incurved deep yellow-could be well called the yellow "Wm. Turner." A sturdy easy grower.

Flamingo. A rich crimson, perfectly reflexed. Good for any purpose.

James Fraser. Color a deep canary yellow; has a rigid stem and fine foliage.

Gorgeous. A golden yellow Japanese, large flowers of fine form.

Master Rex. A distinct Japanese; in color a rich glowing amber. A broad flower.

Meudon. A fine lively bright pink. A dwarf grower with ideal habit.

Mrs. Ernest Wild. Chestnut crimson with bronze reverse. A most reliable sort.

Mrs. H. J. Jones The color is a true Chartreuse green when opening, changing to a rich deep yellow. True Japanese form of the largest size.

Mrs. R. H. Boggs. One of the largest in existence. Pure white.

Nerissa. A fine incurved mauve, of largest size, fine stems and habit.

Odessa. A bright yellow seedling from Merza. Free grower.

Plants from $2 \frac{1}{4}$ in. pots of the above. Each, 20 cts.; dozen, $\$ 2.00$.

\section{GENERAL COLLECTION OF CHRYSANTHEMUIMS.}

Alice Lemon. A beautiful light pink.

Christy Mathewson. A grand white Jap.

C. H. Totty. Glowing chestnut-scarlet.

F. E. Nash. Light pink Japanese.

F. S. Vallis. A very large yellow.

Glen View. A grand dark red.

Hon. Mrs. Lopes. A grand large yellow.

Lady Hopetown. Light pink, large flowers.

Lenox. Light yellow.

Mary Donellan. A fine rich yellow.

Mary Mason. A large bronze red.

Merza. A grand 'white.

Mrs. J. C. Neil. A fine pale yellow.

The above varieties, plants from $21 / 4$ in. pots.

\section{EXHIBITION SINGLE}

Alexander Rowbottom. Bright crimson.

Carrie Wells. A fine pure white.

Caledonia. Rosy lilac, with white disc.

Fair Rosamond. A fine dark pink.

Grace Tower. Lavender pink, a fine flower.

Mary Richardson. Salmon yellow.

Mrs. David Syme. A fine white.

Mrs. G. A. Drexel. Incurved shell pink.

Mrs. Gilbert Drabble. A monster white.

Nakota. An immense yellow.

Mrs. Wm. Duckham. A fine reflexing yellow.

Pocketts' Crimson. A fine crimson.

Rose Pocket. Old gold, shaded bronze.

W. Mease. A bright rosy red.

Wells' Late Pink. Clear, bright pink.

Wm. Duckham. Light pink.

Wm. Turner. The finest pure white.

W. Woodmason. A large reddish crimson.

Yellow Miller. Very large light yellow.

Plants from 2 $1 \frac{1}{2}$ inches pots. Each, 15 cts. dozen, $\$ 1.50 ; 100, \$ 12.00$.

We shall be pleased to supply any other varieties not named above.

For Hardy varieties of Chrysanthemums see page 58.

\section{NEW CARNATIONS.}

Alice. Color a beautiful shade of clear blush pink, without a trace of salmon. The blooms average 3 to $3 \frac{1}{2}$ inches across. A persistent and enormous bloomer all through the fall and winter months.

Champion. The color is true scarlet; rustless with health and vigor. A very free flowering variety and fine grower.

Good Cheer. Color deep pink; stems extra long and stiff, flowers 3 to $3 \frac{1}{2}$ inches across. A good keeper and continuous bloomer.

Gorgeous. A rich glowing crimson, suffused with brilliant vermillion. It is a giant in growth and flowers freely.

Matchless. A very fine white; a free bloomer, very fragrant, with fringed petals. The flowers are large and borne on long stiff stems.

Pink Sensation. Flowers extremely large, averaging 4 inches, full and deep. Keeping qualities better than ordinary. Color a well defined pink.

Princess Dagmar. Very large, nicely formed crimson flowers. The habit is excellent and flowers of the highest type.

Plants from $2 \frac{1}{4}$ in. pots. Spring delivery. Dozen, $\$ 1.50 ; 100, \$ 12.00$. Field Grown plants in Fall. Dozen, $\$ 2.50 ; 100, \$ 16.00$.

For other Carnations see page 61 . 


\section{GREENHOUSE ROSES}

Red Radiance. A red sport from Radiance, an easy doer and will be welcomed by the private growers who grow the pink variety. Grafted or Own Root Stock, $2 \frac{1 / 2}{2}$ in. pots., $\$ 3.00$ doz.; $\$ 25.00,100$.

Hoosier Beauty. In color a rich, velvety crimson with deeper shadings. It is as fragrant as Richmond, has more petals and better keeping qualities. A very strong grower and profuse bloomer.

Grafted stock. $2 \frac{1}{4}$ in. pots: doz., $\$ 3.00 ; 100, \$ 22.50 ; 3$ in. pots: doz., $\$ 4.00 ; 100, \$ 27.50$.

Own Root stock. $2 \frac{1}{4}$ in. pots: doz $\$ 2.00 ; 100, \$ 15.00 ; 3$ in. pots: doz., $\$ 3.00 ; 100, \$ 20.00$.

Francis Scott Key. A heavy double Rose of great substance. Color red. A good grower and valuable acquisition.

George Elger. A dainty yellow polyantha rose. Very similar to Cecile Brunner in habit and growth.

Hadley. Color deep velvety crimson, retaining its brilliancy at all seasons. The buds are well formed and it is a strong, rapid and healthy grower.

Killarney Brilliant. A sport from Killarney with the same habit growth and freedom of bloom as its parent, while the flower is twice as large. The color is a very brilliant pink.

Prince E. C. d'Arenberg. Clear red in color with no trace of blue; excellent in habit of growth.

Own Root stock. $2 \frac{1}{4}$ in. pots: $\$ 2.50$ per doz.; $\$ 15.00$ per 100,4 in pots: $\$ 3.50$ per doz.; $\$ 25.00$ per 100.

Grafted. $21 / 4$ in..pots: $\$ 3.00$ per doz.; $\$ 22.50$ per 100.4 in. pots: $\$ 5.00$ per doz.; $\$ 30.00$ per 100 .

Mrs. Charles Russell. A great Rose in every way; big as American Beauty, with as delightful fragrance, color a lighter shade of cerise, a splendid keeper and will last four times as long as Beauty:

Grafted stock. $2 \frac{1}{4}$ in. pots: $\$ 3.00$ per doz.; $\$ 20.00$ per 100,3 in. pots: $\$ 4.00$ per doz.; $\$ 25.00$ per 100,4 in. pots: $\$ 5.00$ per doz.; $\$ 30,00$ per 100 .

Sunburst. The color is orange-copper or golden-orange and golden-yellow, all intense shades, extremely brilliant in effect. It has a long pointed bud, stem is always stiff, and is extraordinary vigorous and healthy.

Own root stock. $2 \frac{1}{4}$ in. pots: $\$ 2.50$ doz.; $\$ 17.50$ per 100,3 in. pots, $\$ 3.50$ doz.; $\$ 25.00$ per 100,4 in. pots: $\$ 4.50$ doz.; $\$ 30.00$ per 100 .

\section{ROSES FOR FORCING.}

We can supply the following varieties for delivery in spring and summer.

American Beauty

Killarney

Killarney Queen

Lady Hillingdon

My Maryland

Mrs. Geo. Shawyer

Plants from $2 \frac{1}{2}$ in pots. Own Root.

Plants from 3 in. pots. Own Root.

Plants from 4 in. pots. Own Root.

Plants from $2 \frac{1}{4}$ in. pots. Grafted Stock.

Plants from 3 in. pots. Grafted Stock.

Plants from 4 in. pots. Grafted Stock.

\section{Ophelia}

Perle d'Or

Radiance

Richmond

Double White Killarney

White Killarney

$\$ 2.00$ per dozen; $\$ 12.00$ per hundred

2.50 per dozen; 20.00 per hundred

3.50 per dozen; 25.00 per hundred

2.50 per dozen; 20.00 per hundred

3.50 per dozen; 25.00 per hundred

4.50 per dozen; 35.00 per hundred

For other varieties of Roses see page 59 .

\section{COLD STORAGE BULBS}

\section{LILY OF THE VALLEY PIPS FROM COLD STORAGE.}

We have in storage a large quantity of Berlin and Dresden Pips for forcing at any: season of the year.

Lily of the Valley can be forced in about 4 weeks from Cold Storage pips. We cannot supply less than 250 pips.

Marshall's Best Berlin Pips. Per 250, $\$ 7.00$; per 500, $\$ 13.00$; per $1000, \$ 24.00$

Marshall's Matchless Dresden Pips. Per 250, $\$ 7.50$; per 500, $\$ 14.00$; per $1000, \$ 25.00$.

\section{I.ILIES FROII COLD STORAGE.}

Lilium Formosum. Bulbs 9 to 10 inches. Per 100, $\$ 18.00$.

Lilium Multiflorum Giganteum. Bulbs 9 to 10 inches. Per 100, $\$ 20.00$.

Lilium Auratum. Bulbs 9 to 11 inches. Per $100, \$ 20.00$.

Lilium Speciosum Album. Bulbs 8 to 9 inches Per $100, \$ 20.00$.

Lilium Speciosum Album. Bulbs 9 to 11 inches. Per 100, $\$ 28.00$.

Lilium Speciosum Magnificum or Melpomone. Bulbs 9 to 11 inches. Per $100, \$ 18.00$.

Lilium Speciosum Magnificum or Melpomone. Bulbs 11 to 13 inches. Per 100, $\$ 25.00$. 


\section{HORTICULTURAL and FARM BOOKS}

FRUITS, FLOWERS, ETC.

A Woman's Hardy Garden.'Mrs. Ely .....\$1.75 Amateur Aquarist .................. 1.00

Asparagus, f. M. Hexamer ......... .50

Berry Book. Biggle ................ .50

Buibs and Tuberous Rooted Plants ... 1.50

Cabbage and Cauliflower. C. L. Allen .... . .50

Carnation, the American. C. N. Ward. .... 3.50

Celery Culture. R. W. Beattie ......... .50

Cyclopedia Of Horticulture. Bailey. In six volumes; new edition now been published. Per volume ...............6. 6.00

Fertilizers. Gregory .............. .40

Floriculture, Practical. P. Henderson .... 1.50

Flowers, How to Grow Them. Rexford. .. .50

Fruits and Vegetables Under Glass. W

Turner ...................... 5.00

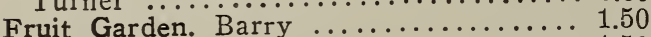

Fruit Growing. Bailey .............. 1.50

Garden Book Biggle. .............. .50

Garden Making. Bailey. . . . . . . . . . . 1.50

Gardening for Pleasure. . . . . . . . . . . 1.50

Gardening for Profit. P. Henderson ........ 1.50

Grape Grower's Guide. Charlton. ......... .75

Greenhouse Construction. L. R. Taft. ... 1.50

Greenhouse Management. L. R. Taft. . . . 1.50

Hand Book of Plants. Henderson ....... 3.00

Hardy Perennials. J. Wood ............. 1.50

Hedges and Windbreaks. E. P. Powell. .. . .50

Horticulturists' Rule Book. Bailey. ...... 2.00

How to Plan the Home Grounds. Parsons 1.00

Landscape Gardening. S. Parsons, Jr. ... 2.00

Lawns and How to Make Them. L. Barron.1.10

Mushroms, How to Grow Them Falconer 1.00

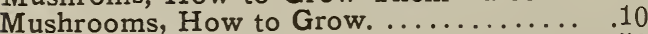

Onion Culture. Greiner ..............50

Orchard Book. Biggle ............. .50

Peach Culture. Fulton. .............. 1.00

Plant Breeding. L. H. Bailey. ........... 1.00

Plant Culture. G. W. Olives. ........... 1.50

Potato Culture. Fitz. .............. .50

Practical Garden Book. .............. 1.00

Propagation of Plants. A. S. Fuller. ..... 1.50

Rose, On the. Parsons. ............... 1.00

Rose Culture. Ellwanger ............. 1.25

Rose Culture, Commercial. E. Holmes. ... 1.50

Rose Growing, Outdoor. Geo. C. Thomas.

Jr. ...................... 4.00

Small Fruit Culturist. Fuller .......... 1.00

Sweet Potato Culture .................50

Strawberry Culture. A. S. Fuller ........... .25

Sweet Peas for Profit. J. Harrison Dick. . 1.50

The Pruning Book ................ 1.50

Tomato Culture. Tracey ............... $\quad .50$

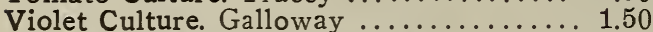

Water Gardening. Peter Bisset .......... 2.50

All books sent postpaid on receipt of price. FARM AND POULTRY.

Alfalfa. F. D: Coburn ...... $\$ 0.50$
American Farm Book............... 2.00

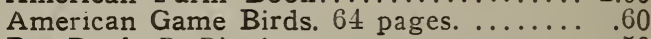

Bee Book. B. Biggle. ................ . . . 50

Biras of Eastern North America. C. A.

Reed ........................ 3.00

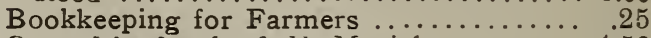

Corn, 'the book of. H. Myrick ........... 1.50

Crops, Spraying. C. M. Weed. ........ . .50

Cyclopedia of Am. Agriculture. Bailey ..20.00

Drainage, Farm. French .............. 1.00

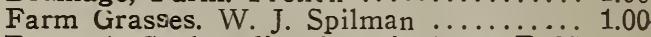

Farmer's Cyclopedia of Agriculture. E. V.

Wilcox and C. B. Smith. ........... 3.50

Farm Machinery and Motors................. 2.00

Fertilizers. Gregory ................ . 40

First Book of Farming. C. L. Goodrich ... 1.10

Forage Crops. Thos. Shaw ............ 1.00

Forestry, Practical. A. S. Fuller ......... 1.50

Horse Book. Biggle ................ .50

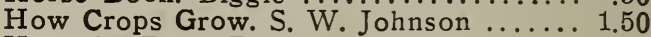

How the Farm Pays. ................. 2.00

Insects and Insecticides. H. $\ddot{M}$. Weed ..... 1.50

Irrigation for the Farm. H. Stewart ..... 1.00

Irrigation Farming. L. M. Wilcox ....... 2.00

Land Draining. Miles ............... 1.00

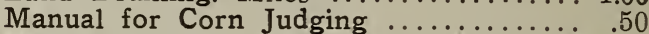

Manures, How to Make, and $\mathrm{How}$ to Use

Them. F. Sempers ................40

Milk and Its Products. $\ddot{H}$. H. Wing ....... 1.00

Modern Horse Doctor. G. H. Dadd ....... 1.00

Pigeon Raising .................. $\quad .50$

Plant Life on the Farm. Masters ........... 1.00

Poultry Book. H. Weir ............... 7.00

Poultry Book. J. Biggle............... . .50

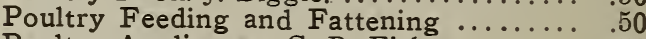

Poultry Appliances. G. B. Fiske ........ . .50

Poultry Architecture .............. .50

Profits in Poultry and Their Profitable

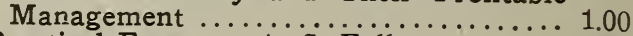

Practical Forestry. A. S. Fuller .......... 1.50

Soiling Crops and the Silo. T Shaw ..... 1.50

Wheat Culture. Curtis .............. 50

\section{THE HOUSE AND GARDEN BOOKS.}

Each book is profusely illustrated.

About 72 p. p.

Making a Bulb Garden. H. S. Adams ....

Making a Garden of Small Fruits. F. F

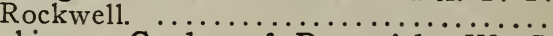

Making a Garden of Perennials. W. C. Egan.

Making a Garden with Hotbed and Coldframe $\ldots \ldots \ldots \ldots \ldots \ldots \ldots \ldots \ldots . \ldots \ldots$

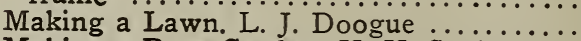

Making a Rose Garden. H. H. Saylor $: \ldots . . .50$

Making a Rock Garden. H. S. Adams .... 50

Making a Water Garden. W. Tricker .... 50

If ordered by mail add 5 cts each for postage.

\section{THE “ATEN' SEWAGE DISPOSAL SYSTEM.}

Every Country Estate Owner is troubled with the problem of disposal of sewage and cesspools.

This system can be installed by anyone, is safe, scientific and inexpensive for the results obtained.

It will take care of all waste from Garrages Stables,

Toilets and Residences, without any menace to your neigh. bors or family.

From the reports we have received where the "Aten" System has been installed it has proved itself to be successful in every detail.

We shall be pleased to have a representative call and explain fully its merits and give estimates for installation or upon request we will mail Illustrated Catalogue giving

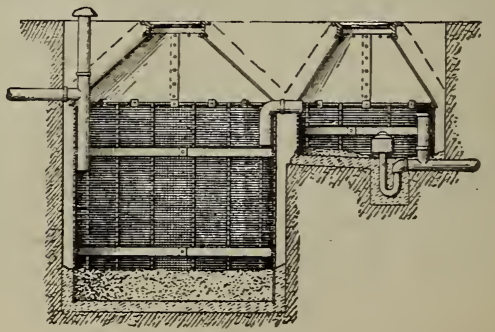
all details. 


\title{
MARSHALL'S VEGETABLE SEEDS
}

\author{
WITH GENERAL DIRECTIONS FOR CULTIVATION.
}

W. E. MARSHALL \& CO. give no warranty, express or implied, as to description, quality, productiveness or any other matter of any seeds, bulbs or plants they send out, and they will not be in any way responsible for the crop. If the purchaser does not accept the goods on these terms, they are at once to be returned.

\section{A R T I C H O K .}

One ounce will sow 100 feet of row, and produce about 500 plants.

A rich sandy loam is best adapted for this plant. The seed should be sown in drills $1 \frac{1}{2}$ inches deep and one foot apart. Transplant to rows 3 feet apart. They rcach maturity the second year, protect in winter by a covering of leaves or coarse manure. cents.

Large French Globe. Heads large, fleshy and of rich flavor. Pkt., 10 cents; ounce, 50

\section{ARTICHOKE PLANTS.}

Large French Globe. Plants ready for shipment after April 1st. Per dozen, \$1.50; per 100, $\$ 12.00$

Jerusalem. Grown for the tubers, which resemble potatoes, and are cultivated in a similar manner, but the rows should be at least 4 feet apart. Quart, 25 cents; peck, $\$ 1.25$.

\section{A S P A R A G U S.}

One ounce will produce about 200 plants.

Sow in Autumn or in Spring as soon as the soil is in good working condition. At one or two years transplant to permanent beds.

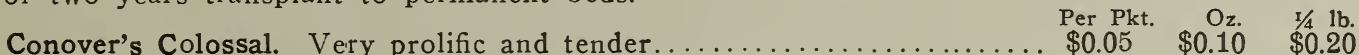

Palmetto. A fine variety, producing large green asparagus .............. $\quad .05 \quad \begin{array}{ll}.05 & .20\end{array}$

\section{ASPARAGUS ROOTS.}

\section{It requires 100 plants for a single row of 150 feet.}

Culture. The permanent bed should be trenched or ploughed very deeply, and well manured with rich, thoroughly decayed manure. Set the plants 18 inches apart in rows, carefully spreading out and separating the roots, and deep enough to admit of the top of the plants being covered 6 inches. In November the plants should have their annual top dressing of manure after the stalks have been cleared away.

TWO-YEAR-OLD ROOTS.

Palmetto. Large bright green..... $\$ 0.80$ Per $\$ 7.00$

Conover's Colossal. Farly deep green $\quad 80 \quad 7.00$

Columbian Mammoth. White..... $80 \quad 800$

Giant Argentiel. Very large...... $80 \quad 7.00$
THREE-YEAR-OLD ROOTS.

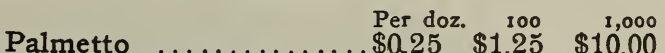

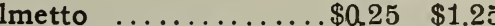

Conover's Colossal .......... $\quad .25 \quad 1.25$

Four Year-Old Roots........ $50 \quad 250$

10.00

\section{B E A N S .}

Beans like a well-drained, rich and light loam. Plant about the middle of April when warm and favorable, and at intervals throughout the season for a succession until the later part of August. Bush varieties should be planted in drills 2 feet apart, and from two to six plants to the foot in a row. Keep them well cultivated and draw the earth up to the stem. For String Beans gather the pods clean as soon as fit for use. The plants will remain all the longer in bearing.

\section{ENGLISH OR BROAD BEANS.}

Sow in drills 2 feet apart, as early in the spring as the ground can be worked (these are as hardy as Peas), in order to get them into pod before the heat of summer.

One quart will plant 100 feet of drill.

Early Long Pod. The earliest and most prolific. Per pint, 20 cents; quart, 40 cents.

Green Broad Windsor. The largest variety grown. Per pint, 20 cents; quart, 40 cents. 


\section{DWARF GREEN-PODDED SNAP BEANS.}

One quart will plant 100 feet of drill.

Black Valentine. Resembling the Valentine, but with black seed; Per $1 / 2$ Pt. Pint Quart $1 / 2$ Peck long round, solid pods; very early................... \$0.20 $\$ 0.40 \$ 0.75 \quad \$ 2.50$

Bountiful. Early, very prolific and long-bearing; flat, green pods

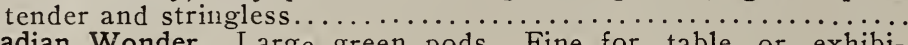

Canadian Wonder. Large green pods. Fine for table or exhibi-

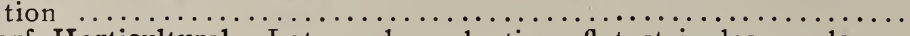

Dwarf Horticultural. Late and productive; flat stringless pods....

Early Mohawk. Long, straight, flat pods, early, hardy and productive

Extra Early Refugee. Two weeks earlier than the Late Refugee,

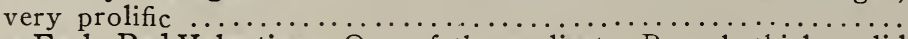

Extra Early Red Valentine. One of the earliest. Round, thick, solid

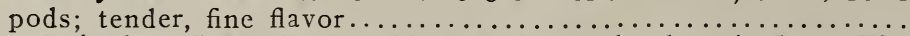

Giant Stringless Green Pod. This bean is absolutely stringless. The

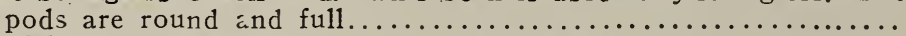

Longfellow. Long, straight, round, solid green pods; very early... Long Yellow Six Weeks. Very early with full flat pods...........

Refugee, Late, or 1,000-to-1. Medium to late; very productive and tender; largely grown for main crop; round pod..............

Stringless Green Pod. An early round green-podded bean; stringless

Wonder of France. A good forcing variety $\ldots \ldots \ldots \ldots \ldots \ldots \ldots \ldots$

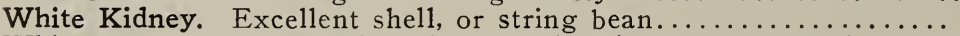

White Marrow. For use in a dry state in winter, or as a string bean

$\begin{array}{llll}.15 & .30 & .50 & 2.25 \\ & & & \\ .15 & .30 & .60 & 2.25 \\ .15 & .30 & .60 & 2.25 \\ .15 & .30 & .60 & 2.25 \\ .15 & .30 & .60 & 2.25 \\ .15 & .30 & .60 & 2.25 \\ & & & \\ .20 & .35 & .70 & 2.50 \\ .15 & .30 & .60 & 2.25 \\ .15 & .30 & .60 & 2.25 \\ & & & \\ .15 & .25 & .50 & 1.75 \\ .20 & .35 & .75 & 2.50 \\ .25 & .50 & 1.00 & 3.00 \\ .15 & .25 & .50 & 1.75 \\ .15 & .25 & .50 & 1.75\end{array}$

\section{DWARF WAX-PODDED BEANS}

One quart will plant 100 feet of drill.

Black Wax, Curie's Rust Proof. Large flat pods, early

Black Wax, Improved Prolific. The pods are round, and of fine

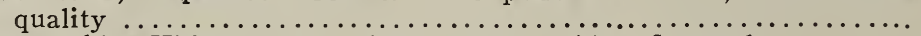

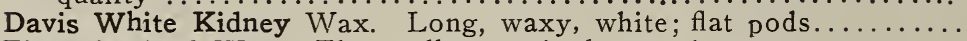

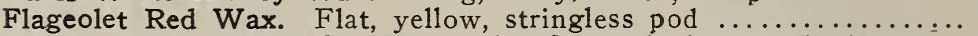
Golden Wax, Improved. Very early; flat pods long, stringless..... Golden-Eyed Wax. Very hardy and prolific, with flat, yellow pods. Golden Scimitar or Pencil Pod Black Wax. Long, round yellow

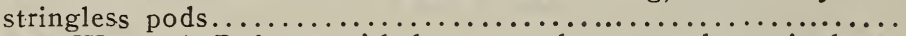

Refugee Wax. A Refugee with long round, wax pods; stringless..

Valentine Wax. A perfect Valentine Bean, with wax pods.........

Per $1 / 2$ Pt. Pint Quart $1 / 2$ Peck Wardwell's Kidney Wax. Early; long, flat, wax pods.............

Yosemite Mammoth Wax. Long, thick, solid pods; finest quality...

$\begin{array}{rrrr}.20 & .40 & .75 & 2.50 \\ .20 & .40 & .75 & 2.50 \\ .20 & .40 & .75 & 2.50 \\ .20 & .40 & .75 & 2.50 \\ .20 & .40 & .75 & 2.50 \\ & & . & \\ .20 & .40 & .75 & 2.50 \\ .20 & .40 & .75 & 2.50 \\ .25 & .50 & 1.00 & 3.50 \\ .20 & .40 & .75 & 2.50 \\ .25 & .50 & 1.00 & 3.50\end{array}$
The 1915 harvest of Beans was almost an entire failure. Prices are subject to change.

\section{DWARF OR BUSH LIMA BEANS.}

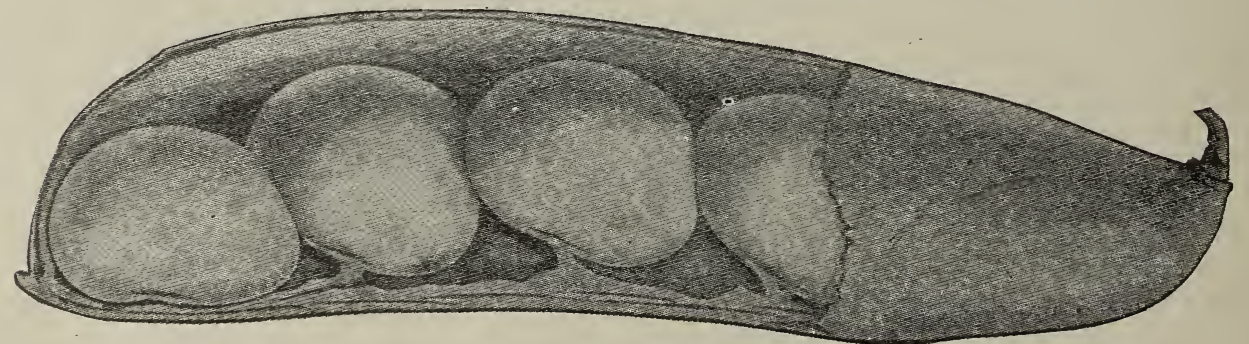

Fordhook Bush Lima Bean.

Burpee's Improved Bush Lima. A bush form of the large flat Pole

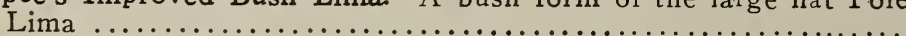

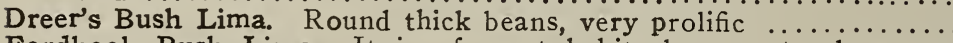

Fordhook Bush Lima. It is of erect habit; beans very large and

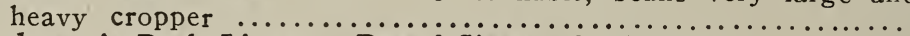

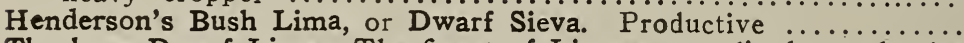

Thorburn Dwarf Lima. The finest of Limas, exceedingly productive Per $1 / 2$ Pt. Pint Quart $1 / 2$ Peck

Farmogerm for Beans. Small size, 25 cents; garden size, 50 cents.

$\begin{array}{rrrr}\$ 0.10 & \$ 0.20 & \$ 0.40 & \$ 1.50 \\ .10 & .20 & .40 & 1.50 \\ .15 & .25 & .50 & 1.75 \\ .10 & .20 & .40 & 1.50 \\ .10 & .20 & .40 & 1.50\end{array}$




\section{BEANS--Continued POLE OR RUNNING BEANS.}

Sow from the first of May (for all except Limas) to the latter part of May, in hills 4 feet each way. Limas should not be planted until warm weather has fairly set in. One quart of Limas will plant about 100 hills, allowing four or five beans to a hill, and of the smaller sorts about 200 hills. Poles 8 to 10 feet long should be firmly set in the hills before planting seed.

Set poles 4 feet apart each way, and plant 4 to 6 Beans about 1 inch deep, around each pole. Thin out to 3 plants to a pole, if the soil is rich; pinch off the ends of plants when they overrun the top of the poles, to effect more perfect growth below.

Challenger Lima. Thick and productive. Best of all ..............
Dreer's Improved Lima. A great improvement upon the Large Lima, being more productive and of better quality.................

Extra Early Jersey Lima. This variety is ten days earlier than the ordinary variety, while it is equal in flavor and productivene:s...

Large White Lima. One of the best shell beans grown; matures in ninety days; very popular. Our seeds of this variety are extra

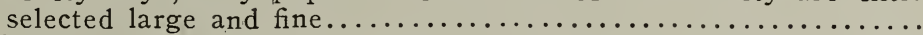

Leviathan Lima. The earliest variety of Pole Lima; produces pods in clusters. A good variety where the season is short...........

Small Sieva or Caroliná. Small size, early and prolific...............

Dutch Case Knife. Pods long, green and flat; can be either snapped

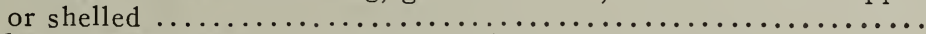

Golden Cluster Wax. Long golden yellow pods in cluster..............

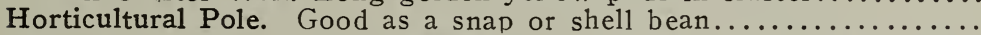

Kentucky Wonder (Old Homestead). Pods green, very long and flat

Scarlet Runner. A popular English pole-bean; very ornamental......

$\begin{array}{llll}.10 & .20 & .35 & 2.25 \\ .10 & .20 & .35 & 2.25 \\ & & & \\ .10 & .20 & .35 & 2.00 \\ .10 & .20 & .35 & 2.25 \\ .10 & .20 & .35 & .2 .25 \\ .10 & .15 & .30 & 2.00 \\ .15 & .25 & .50 & 3.00 \\ .10 & .15 & .30 & 2.00 \\ .10 & .20 & .35 & 2.25 \\ .10 & .20 & .35 & 2.25\end{array}$

\section{B E E T.}

One ounce will sow 50 feet of drill.

For early supply sow as soon as the ground is in working order, in drills one foot apart and two inches deep. For main crop, sow the second week in May, and for winter use sow in June. When the plants are well forward thin out to about 9 inches apart. The young Beets, with their tops pulled out of the row, are excellent, used as Spinach.

Early Blood Turnip. The leading early sort; also fine for late use... $\$ 0.05 \$ 0.15 \$ 0.40 \$ 1.50$

Early Eclipse. Very early, dark blood color, small top................ $.05 \quad .15 \quad \begin{array}{lll}40 & 1.50\end{array}$

Extra Early Egyptian. The best for first crop out out of doors. The

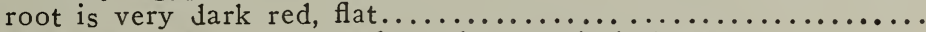

Crosby's Egyptian. Extra early early, round, dark red.............

Crimson Globe. Fine globular shape; flesh deep purple; fine quality... Detroit Dark Red Turnip. Round; skin dark blood-red; flesh bright red

Long Smooth Blood. A prolific variety, very dark in color. . .........

Marshall's Exhibition Globe. Very carefully selected stock, dark red

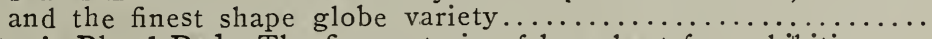

Sutton's Blood Red. The finest strain of long beet for exhibition.....

Sutton's Globe. A perfect globe shaped variety..................

Swiss Chard. The roots of this variety are of no value, but the leaves

are superior to those of the ordinary beet, and excellent as greens .05

Swiss Chard, Giant Lucullus. An improved variety.............. .05

$\begin{array}{llll}.05 & .15 & .40 & 1.50 \\ .05 & .15 & .40 & 1.50 \\ .05 & .15 & .40 & 1.50 \\ .05 & .15 & .40 & 1.50 \\ .05 & .15 & .40 & 1.50 \\ .05 & .15 & .40 & 1.50 \\ .10 & .25 & .75 & 2.50 \\ .10 & .15 & .50 & 1.50 \\ .10 & .15 & .50 & 1.50 \\ .05 & -.15 & .40 & 1.00 \\ .05 & .15 & .40 & 1.00\end{array}$

\section{A N G E L - W U R Z E L}

Sow 6 to 8 pounds per acre.

Champion Yellow Globe. Bright orange color, globe-shaped and of excellent $1 / 4 \mathrm{Lb}$. Lb.

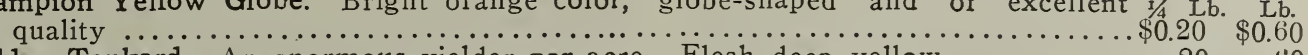

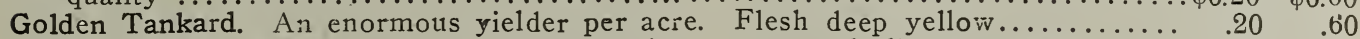

$\begin{array}{llll}\text { Mammoth Long Bed. The largest and heaviest cropper of all the Mangels...... } & .20 & .60\end{array}$

\section{S U G A R B E E T}

Klein Wanzeleben. The most popular variety; root conical, straight, and even.. $\$ 0.20 \quad \begin{aligned} & \mathrm{Lb} \text {. } \\ & \$ 0.60\end{aligned}$

Imperial White Sugar. An old variety of the Sugar Beet, valued for its produc-

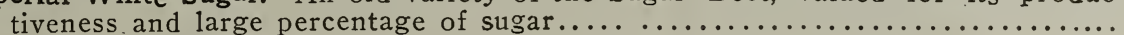

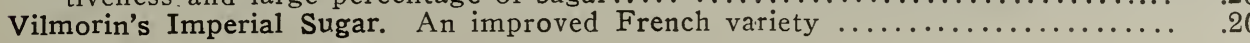




\section{B R O C C O L I.}

For Cultural Directions see Cauliflower.

Purple Caper. Per Oz, $1 / 4 \mathrm{Lb}$. White Cape. White Cape. Heads compact and of a creamy white color............. $\quad .10 \quad \begin{array}{r}.50 \\ 1.25\end{array}$

\section{BRUSSELS SPROUTS.}

One ounce will produse about 2,000 plants.

Sow in May, in shallow drills, 1 inch deep and 12 inches apart. Transplant in July. A very hardy delicious vegetable which should find a place in every garden; greatly improved by hard frosts.

One ounce will produce 3,000 plants.

Marshall's Exhibition. The finest variety of all the Brussels Sprouts. Very Per Pkt. Per Oz. I/4 Lb.

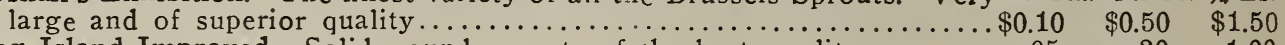

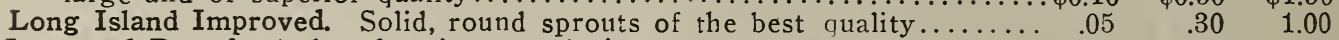

$\begin{array}{lllll}\text { Improved Dwarf. A dwarf variety, producing numerous heads............ } & .05 & .20 & .60\end{array}$

\section{A B B A G E.}

One ounce will produce 3,000 plants.

For early use sow the seeds in hotbeds in February or March. Transplant as soon as the ground can be worked, in rows 2 feet apart, and the plants 18 inches apart in the rows. For late or winter use sow the seed in May.

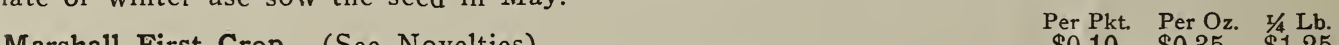

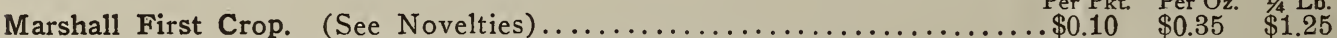

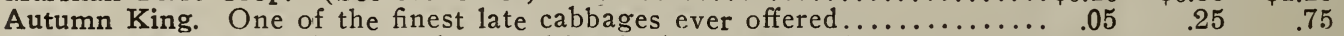

Copenhagen Market. Very early round head, short stemmed ............. $10 \quad \begin{array}{llll}.50 & .1 .50\end{array}$

Danish Ball Head. Very round, solid winter sort. A fine shipper...........

Early Flat Dutch. A second early cabbage; large solid heads............. $\quad .05 \quad \begin{array}{llll}.25 & .75\end{array}$

Early Spring. An extra early cabbage, with a rolind flat head................$^{05} \quad .25 \quad .75$

Early Jersey Wakefield. The standard early variety; conical in shape; few

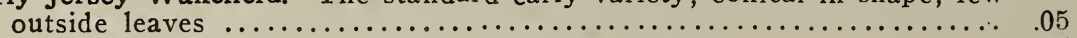

Early Winnigstadt. Conical shape; quality very good................. .05

Improved Early Summer. A superior second early sort ................ 05

Large Late Flat Dutch. The heads are large and solid, with few outer

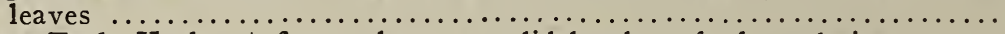

Large Early York. A fine early sort; solid heads and of good size........

Large Late American Drumhead. One of the largest and best keeping va-

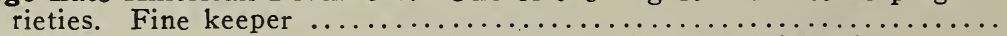

Succession. A week later than Early Summer. Large solid heads......... 05

\section{SAVOY CABBAGE.}

Early Dwarf Ulm. A very early dwarf variety of fine quality ......... $\$ 0.05$

Perfection Drumhead. A large improved strain. Strong and vigorous

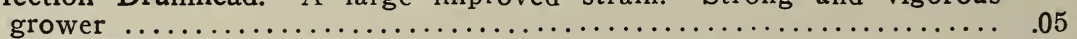

Marshall's Exhibition. Medium sizes, beautifully curled leaves.......... 10

\section{RED CABBAGE.}

Early Red Erfurt. A standard variety; heads solid and large size........ $\$ 0.05$

Large Red Drumhead. Heads round, solid, and dcep blood-red in color... .05

Mammoth Rock Red. The largest red cabbage; color deep red........... .05

Red Stonehead. Medium size but very solid heads.................. 10

For Early Cabbage, plant, Frost Proof Plants, see page 31.

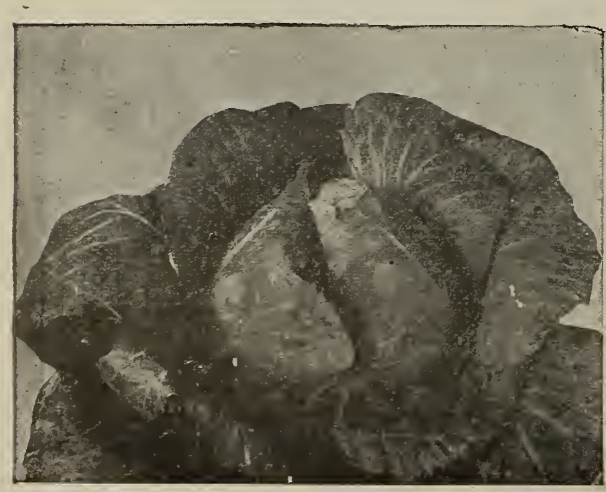

Jersey Wakefield Cabbage.

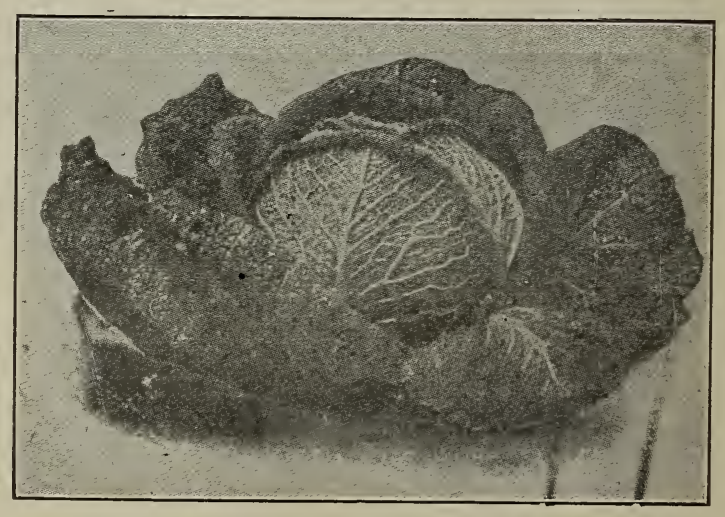

Marshall's Exhibition Savoy Cabbage. 


\section{A R D O O N.}

Large Solid Grows about 4 feet high; leaves nearly free from spines. Pkt., 5 cts.; oz., 25 cts.

\section{A R R O T S .}

One ounce will sow 100 feet of row.

For early crops sow as soon as the ground can be worked, and for later crops from the beginning until the end of May, in rows 15 in shes part and $1 / 2$ inch deep. Thin out the young plants to 5 inches and keep the surface open bv frequent use of the hoe.

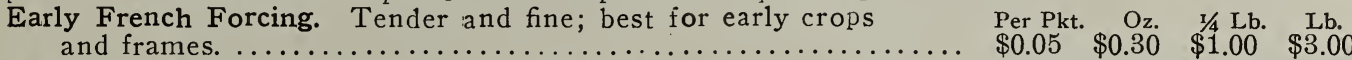

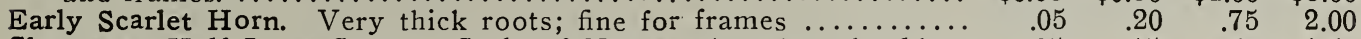

Chantenay Half Long Stump. Style of Nantes, broader shoulder.. $\quad .05 \quad \begin{array}{lllll}.15 & .50 & 1.50\end{array}$

Danver's Half Long. Large; of good quality and productive; one of the most popular sorts............................ $.05 \quad .15 \quad .50 \quad 1.50$

Half Long Stump-rooted, Nantes Strain.. Very popular ............

Long Orange. For garden and field crops this is the best variety

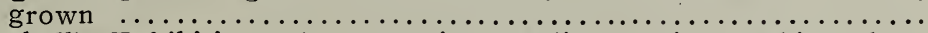

Marshall's Exhibition. A superb intermediate variety, skin clear,

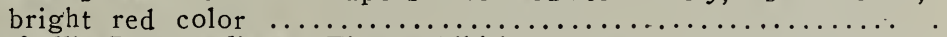

Marshall's Intermediate. Fine exhibition variety $\ldots \ldots \ldots \ldots \ldots \ldots$
New York Market. Bright orange color. It has a small core; is

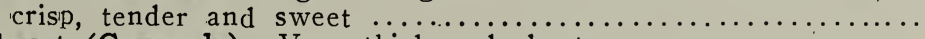

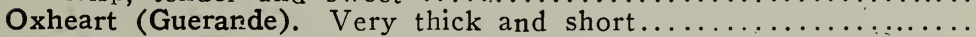

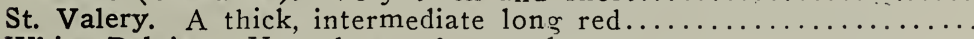

White Belgian. Very large; for stock.

$\begin{array}{llll}.10 & .20 & .60 & 2.00 \\ & & & \\ .10 & .20 & .30 & 2.00 \\ .10 & .20 & .60 & 2.00 \\ & & & \\ .05 & .15 & .50 & 1.50 \\ .05 & .15 & .50 & 1.50 \\ .05 & .15 & .50 & 1.50 \\ .05 & .10 & .35 & 1.25\end{array}$

\section{A U LIF L O W E R.}

One ounce of seed produces about 3,000 plants.

By sowing the early varieties in a hot-bed in February or March, or later in a cold-frame, fine heads can be obtained quite early. When large enough, transplant, making the rows about $2 \mathrm{~T} / 2$ feet apart and 8 inches between the plants. Transplanting should be done in moist weather.

Marshall's First and Best. Produces large and fine grained heads of snowy

whiteness. It is the earliest and most solid heading variety grown....
Earliest Dwarf Erfurt. The best and earliest for forcing under glass; very Per Pkt. $\quad 1 / 4 \mathrm{Oz}$. Oz. dwarf and compact, with short stem and small leaves...............

$\$ 0.50 \$ 2.25 \$ \$ .00$

Marshall's Extra-Early-Snowball. One of the best for forcing under glass

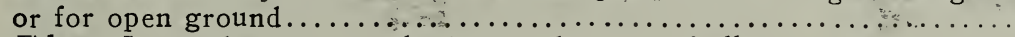

Gilt-Edge. Large, heavy sort; the best and surest of all................

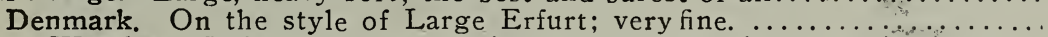

Dry-Weather. This variety is especiallv adapted for long, dry seasons....

Large Early Erfurt. Popular with market gardeners for late crop............

Extra-Early Paris. Heads of medium size; first class . . . . . . . . . . . . . .

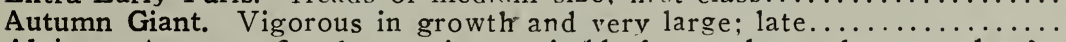

Algiers. An extra fine late variety; suitable for market and sure to thead..

$\begin{array}{lrr}.50 & 1.75 & 6.00 \\ .25 & .75 & 2.50 \\ .25 & .75 & 2.50 \\ .20 & .75 & 2.50 \\ .20 & .75 & 2.50 \\ .10 & .75 & 2.25 \\ .10 & .25 & .75 \\ .05 & .15 & .40 \\ .05 & .20 & .50\end{array}$

\section{E L E R Y.}

One ounce will sow about 300 feet of a row and produce about 5,000 plants.

Sow in the open border early in April, in ri:h ground. When the plants are 3 inches high, transplant 4 inches apart into temporary beds of soft rich soil until they acquire sufficient strength for planting out. Plant in rows 3 feet apart, and set 8 inches apart in the rows: About the mis ale of August earthing up is necessary for blanching and whitening of that which is wanted for earlv use. $\quad$ Per Pkt. Oz. $\mathrm{O}^{3 / 4 \mathrm{Lb}}$.

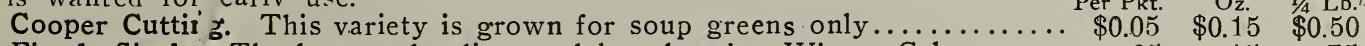

Fin de Siecle. The largest, hardiest and best-keefing Winter Celery...... $.05 \quad .15 \quad .75$

Giant Paccal. The stalks are solid and crisp.kolien-yellow heart....... .05

Golden Dwarf or Golden Heart. A distinct variety; crisp solid; fine flavor $\quad .05 \quad .20 \quad .60$

Golden Self-Blanching. French grown; crisp, tender and of fine flavor $\quad .25 \quad 1.50 \quad 4.00$

Market Red. Large and very solid; a fine table variety $\ldots \ldots \ldots \ldots \ldots \ldots \ldots \ldots . .50 \ldots \ldots$

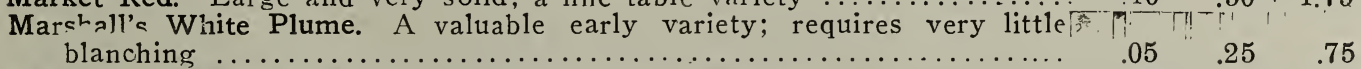

Perfection Heartwell. Medium height and blanches well .................

Pink Plume. Strong, compact grower; stems soiit and crisp.............

Schumacher. A large growing sort; solid, crisp and of a fine nutty flavor. $\quad .05 \quad .25 \quad .75$

Winter Queen. Very large, solid green, Winter variety; blanches well .... $\quad .05 \quad .25 \quad .75$

Celery Seed. Used for flavoring only. ............................. . $10 \quad .15$

CELERIAC, or TURNIP.ROOTED CELERY

Large Erfurt. A standard variety; producing turnip-shaped roots........ $\quad .05 \quad .20 \quad .60$

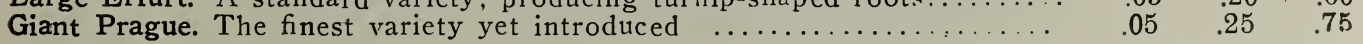




\section{H E R V I L.}

The curled Chervil is cultivated like parsley and used for garnishing and flavoring soups and salads.

Curled Chervil. The Per Pkt. Oz. ${ }^{\mathrm{T} / 4} \mathrm{Lb}$.

\section{H I C O R Y.}

Common, or Wild. Sow in June; the roots are transplanted in Autumn into

sand, in a cellar. The young shoots form the Barbe de Capucin, the cele- Per Pkt. Oz. 1/4 Lb.

brated salad of France................................... \$0.05 $\$ 0.15 \$ 0.30$

Large-Rooted Magdeburg. Used to mix with or a substitute for coffee..... $\quad .05 \quad .15 \quad .40$

Witloof, or French Endive. The stalks when blanched are used for salad. ${ }^{2} .05$

\section{O L L A R D S.}

Sow seeds, as for cabbage, in June, July and August, for succession. Transplant when a month old in rows a foot apart each way, and hoe often.

Georgia . $\$ 0.05 \$ 0.10 \$ 0.25$

\section{CORN SALAD OR FETTICUS.}

One ounce will sow 150 feet of drill.

Sow in September in drills eight inches apart, covering the seeds lightly and protect from frost by light covering of hay and litter. The seed may be sown in Spring.

Large-Seeded. The most popular variety grown. Pkt., $5 \mathrm{cts}$; oz., $10 \mathrm{cts}$.; $1 / 4 \mathrm{lb}$., $25 \mathrm{cts} \cdot 1 \mathrm{~b}$., $75 \mathrm{c}$.

\section{S W E E T C O R N.}

One quart will plant 200 hills.

Plant in hills three feet apart each way, dropping five or six kernels in each hill, or in rows three feet apart, and the plants thinned out to eight or nine inches in the row. From May until the middle of July a succession planting can be made every two or three weeks, and a continued supply can be had until frost kills the plants.

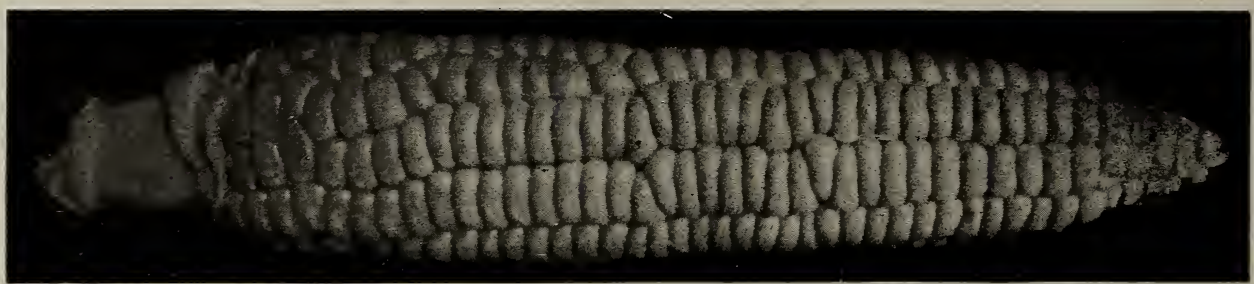

Golden Bantam Sweet Corn.

EXTRA-EARLY

Early Mayflower. One of the earliest white seeded varieties; long, well-filled Per Pt. Qt. Pk. ears ................................... \$0.20 $\$ 0.40 \$ 2.50$

Early Minnesota. One of the earliest varieties grown; dwarf; ears small... $\quad .15 \quad .25 \quad 1.50$

Golden Bantam. Extra early; yellow; very sweet and tender............. $.15 \quad .30 \quad 2.00$

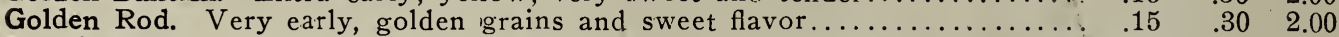

Howling Mob. An early variety of large size ears; white, sweet grains . . . . $\quad .15 \quad .30 \quad 2.00$

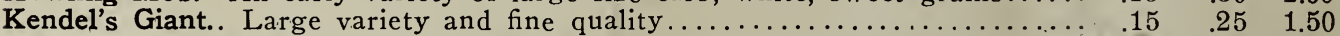

Mammoth White Cory.. Ears double the size of the old Cory... .......... $18 \quad .25 \quad 1.50$

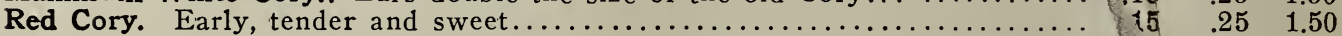

SECOND EARLY.

Crosby's Early. One of the standard early sorts $\ldots \ldots \ldots \ldots \ldots \ldots \ldots \ldots \ldots \ldots \ldots \ldots \ldots .5 \%$

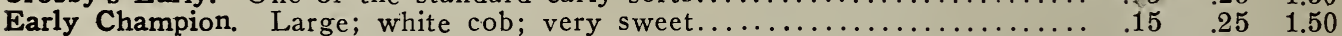

Early Evergreen. Ripens about ten days earlier than Stowell's Evergreerı... $\quad .15 \quad .25 \quad 1.50$

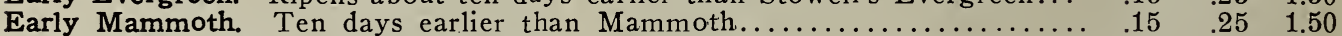

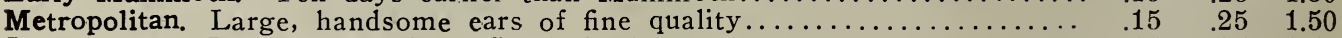

Squantum, or Poter's Excelsior. Good sized ears . . . . . . . . . . . . . . . $.15 \quad .25 \quad 1.50$

GENERAL AND LATE.

Black Mexican. The sweetest and most delicious variety grown ........ $.15 \quad .25 \quad 1.50$

Country Gentleman. Ripens about the same time as Stowell's Evergreen. Ears medium size; deep grains in irregular rows on cob and deliciousiy

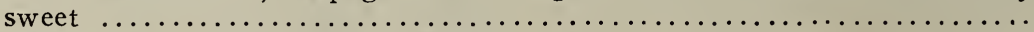

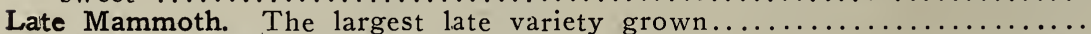

Stowell's Evergreen. The most popular variety grown; ears large and very

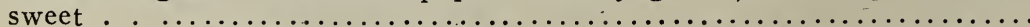

Packets of all varieties of corn, 10 cents each, post free.

POP-CORN. White Rice, Per lb., 15 cts.

$\begin{array}{lll}.15 & .25 & 1.50 \\ .15 & .25 & 1.50\end{array}$




\section{CRESS OR PEPPERGRASS.}

One ounce will sow 150 feet of drill.

A popular salad which should be sown early in the Spring very thickly in shallow drills, and at short intervals for succession, as it soon : u: $s$ to seed.

Extra Curled. The best variety grown; leaves are beautifully cut and curled;

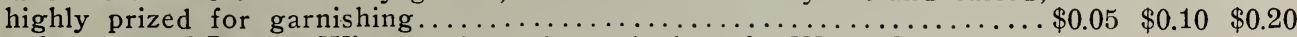

Upland, or Broad-Leaved Winter. A garden substitute for Water Cress; cr:sp,

tender and perfectly hardy ............................................

True Water Cress. Water Cress requires a stream of running water, ditch
or pond, in which it will grow without care, except at first keeping weeds

from interfering with it...

$.05 \quad .10$

$.05 \quad .40 \quad 1.25$

\section{U C U M B E R S.}

One ounce to fifty hills; two to three pounds to one acre.

For very early use, seed may be started in heat and the planis set out in May. Pieces of inverted sod are an excellent medium for starting and growing early cucumber plants, as they can readily be lifted from the hot-bed to the garden without disturbing the young plants growing upon them. For maincrop. plant in hills four feet apart, at the end of May. Keep the young plants safe from the striped bug by dusting with dry plaster or powdered hellebore. Leave four strong plants to each hill.

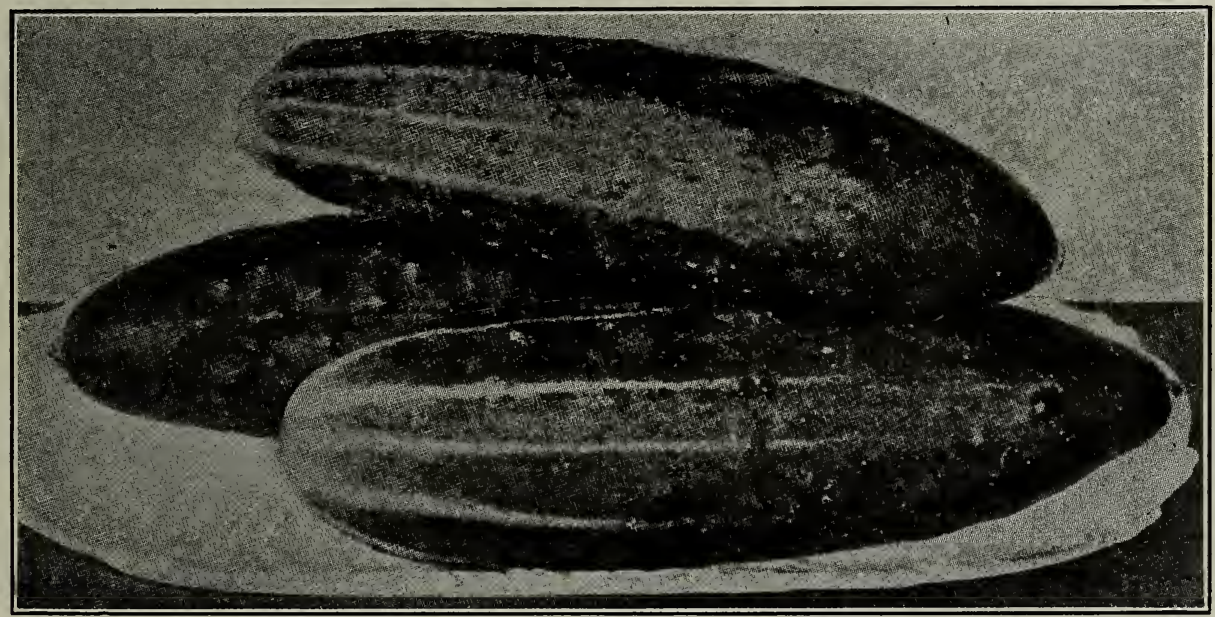

Improved White Spine Cucumber

Cool and Crisp. A strain of White Spine; flesh peculiarly crisp and tender... $\$ 0.05 \$ \$ 0.15 \quad 30.40$

Cumberland. A variety of the hardy White Spine type.............. $.05 \quad .15 \quad .40$

Davis Perfect. An excellent variety both for outdoors and forcing purposes $\quad .05 \quad .15 \quad .40$

Early Cluster. Prolific, tender and crisp; about five inches long; good color $.05 \quad .10 \quad .35$

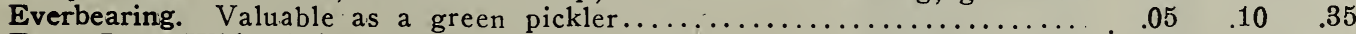

Extra Long White Spine. Much longer than ordinary White Spine; very prolific

Green Prolific Pickling. Dark green; medium strength; very free bearer....

Improved Long Green. Long and crisp; a popular variety for pickles......

Improved White Spine. Elarly and good for table use or for pickling; of medium length; dark green color, and flesh crisp and excellent........... Japanese Climbing. This is a strong and vigorous grower; ne for pickling.

West Indian Gherkin. Used only for pickles; the smallest of all varieties....

Lemon Cucumber, or Garden Lemon. An almost round variety; yellow and green markings; tender and of sweet flavor; resembles a lemon in ap-

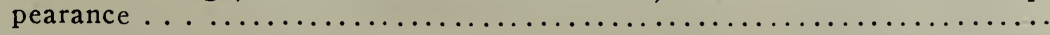

$\begin{array}{lll}.05 & .15 & 40 \\ .05 & .15 & 40 \\ .05 & .15 & 40 \\ & & \\ .05 & .15 & 40 \\ .05 & .15 & .40 \\ .95 & .15 & .45 \\ & & \\ .05 & .20 & .50\end{array}$

ENGLISH CUCUMBERS FOR FRAMES.

Telegraph, Duke of Edinburgh, Tender and true, Covent Garden Favorite, Lockie's Perfection, Sutton's Matchless.............................each pkt. of 10 to 15 seeds 25 cts. 


\section{A N D E L I O N.}

The Dandelion affords one of the earliest and most healthful Spring greens or salads. Improved French. Pkt., 5 cts.; oz., 30 cts.; $1 / 4$ lb., $\$ 1.00$.

\section{E N D I V E.}

One ounce of seed for 75 feet of drill.

One of our best salad plants. For a first crop, sow about the middle of April; for succession, small sowings may be made every month till August, when the main planting is made. Set out the plants one foot apart, in rows and when well grown blanch by folding the leaves. Broad-Leaved (Escarolle). Leaves long and broad; thick and succulent..... $\$ 0.05 \quad \$ 0.15 \quad \begin{aligned} & \mathrm{T} / 4 \mathrm{Lb} \\ & \$ 0.40\end{aligned}$ Green Curled. Hardy, finely curled; easily blanched; one of the best........ $.05 \quad .15 \quad .40$ White Curled. Blanches rapidly; excellent and very tender............... $\quad .05 \quad .15 \quad .40$

\section{E G G P L A N T .}

One ounce will projuce about 2,000 plants.

The Egg-Plant will thrive weIl in good garlen soil. The seed should be sown in hot-bed or warm green-house in March or April, and when about an inch high, put in two-inch pots. Plant about June $1,21 / 2$ feet apart. If no hot-bed is at hand, they can be grown in any light room where the temperature will average 75 degrees.

Buck... Pkt. Oz. I/4. Lb.

Black Beauty. As large as New York Improved but ten days earlier.......\$0.10 \$0.40 \$1.25

Black Pekin. Very fine, large globular fruit of a dark, glossy purple color.... $.05 \quad .40 \quad 1.25$

Long Purple. Fruit longer and smaller than the above sort; hardy; productive $\quad .05 \quad .25 \quad .75$

New York Improved. Purple; the best variety; very large, oval, heavy_fruit. . $\quad .10 \quad .40 \quad 1.25$

\section{KALE, OR BORECOLE.}

Sow about the middle of April in prepared beds, covering thinly and evenly; plant out in June, following the directions recommended for cultivating cabbage.

Curled Dwarf Green Scotch. Very dwarf and spreading; best strain........ $\$ 0.05 \quad \begin{array}{ll}\mathrm{Oz} .10 & \mathrm{I} / 4 \mathrm{Lb} . \\ \$ 0.30 & \end{array}$

Marshall's Exhibition Curled. Closely curled leaves.................... $.10 \quad .25 \quad .75$

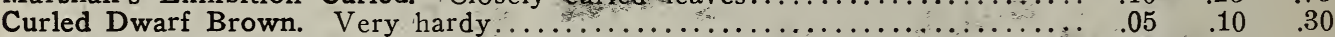

Curled Siberian Improved. Uniformly dwarf; green curled; hardy $\ldots \ldots \ldots \ldots \ldots .05 \quad .10 \quad .25$

Sea Kale. Very fine; resembles celery............................. $10 \quad 30 \quad .75$

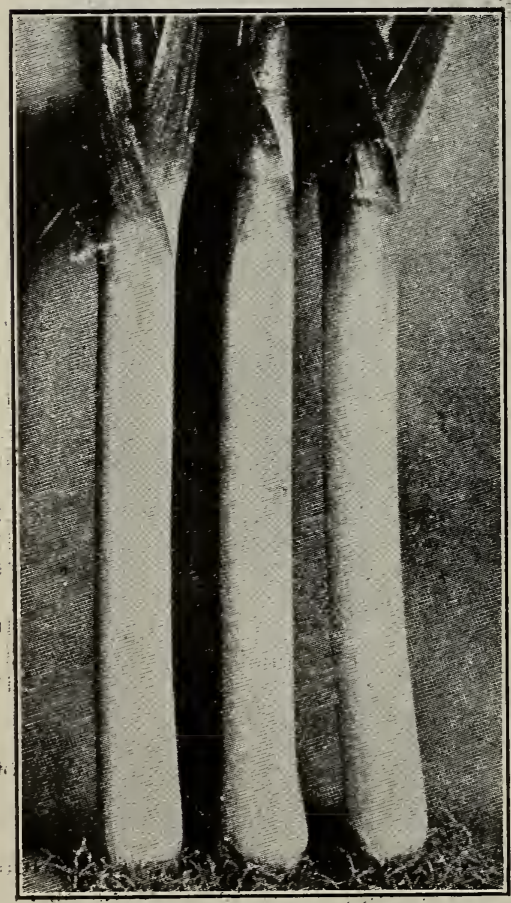

Marshall's Giant Leek.

\section{KOHL-RABI.}

One ounce will sow 200 feet of row.

Cultivate the same as the cabbage, but in hoeing be careful not to throw earth into the heart of the plant or the bulb cannot be formed.

Early White Vienna. Handsome and delicate .................. $\$ 0.05 \quad \$ 0.25 \quad \$ 0.75$

Early Purple Vienna. Similar to the preceding, except in color........

Large White, or Green. Forms a large ball; not so fine, but more productive ....................

$$
\text { Pkt. Oz. } \quad 2 / 4 \mathrm{Lb} \text {. }
$$$$
\$ 0.25 \quad \$ 0.75
$$

\section{E E K .}

\section{One ounce will sow 200 feet of drill}

The Leek is very hardy and easily cultivated; it succeeds best in light but well-enriched soil. Sow as early in the Spring as practicable, in drills one inch deep and one foot apart." When six or eight inches high, transplant in rows 10 inches apart each way, as deep as possible, that the neck, being covered, may be blanched.

Marshall's Giant. The largest and best Leek for exhibition. Highly recommended as the choicest variety in cultivation, of a mils and delicious flavor. ................

Large American Flag. . The most desirable for masket or family use..

Musselburgh, or Carentan. A very large variety of superior quality..
Pkt. Oz. $\quad 1 / 4 \mathrm{Lb}$.

$\$ 0.10 \quad \$ 0.40 \quad \$ 1.00$

$05 \quad .20,60$

$.05 \quad .20 \quad .60$ 


\section{E T T U C E.}

One ounce will so 200 feet of drill.

Sow in the open ground as early as possible, barely covering the seed. If the hot-bed is used, let it be started quite early. Give but listle heat and plenty of water and air on fine days. Let plants in the bed be about 4 inches apart. As they increase in size thin them out, or they will become weak. Plant for late use in a cool, partially shaded place, in rich soil.

\section{CABBAGE or HEADING VARIETIES.}

All Seasons. Large, handsome, extremely solid head; color a light grayish-

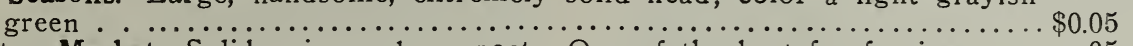

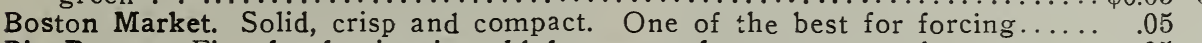

Big Boston. Fine for forcing in cold frames or for open ground..........

Deacon. A splendid variety for standing the Summer heat; large, solid head. . .05

Giant Crystal Head. . Large, solid; outside leaves bright green; inside white.. .05

Golden Queen. A good forcing variety of a golden yellow color; heads solid .05

Hanson Improved Heads large, hearts quickly, and stands the Summer well .05

Iceberg. Large solid heads; yellow heart; very crisp..................

Mammoth Black Seeded Butter. A large head lettuce of splendid quality.....

May King. Extra large, solid heads; light green outside, with clear yellow heart; very tender and of fine flavor; splendid forcer................

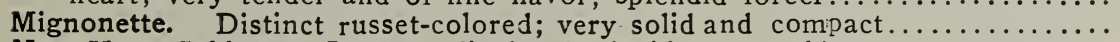

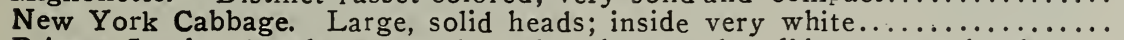

Private Stock. A selected stock, and makes good, solid, compact heads......

Improved Salamander. Large heads that stand the draught and heat........

Tennis Ball (Black Seeded). A very compact head with few outer leaves....

Way Ahead. The leaves are light green, heads blanched to a rich yellow tint

White Summer Cabbage. A fine Summer variety; heads of good size.........

Wonderful. It stands the heat well, making a fine variety for all seasons....

\section{CURLED or LOOSE-LEAVED VARIETIES.}

Black-Seeded Simpson. Nearly double the size of Curled Simpson.........

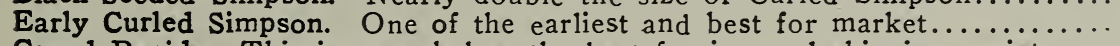
Grand Rapids. This is regarded as the best forcing and shipping variety.... ROMAINE, or CO $>$ VARIETIES.

Oz. $\quad 1 / 4 \mathrm{Lb}$.

$\$ 0.20 \$ 0.40$

$.20 \quad .40$

$.20 \quad .50$

$.15 \quad .40$

$.20 \quad .50$

$.15 \quad .40$

$.20 \quad .50$

$.20 \quad .50$

$\begin{array}{lll}.05 & .20 & .50 \\ .05 & .20 & 50\end{array}$

$\begin{array}{lll}.05 & .20 & .50\end{array}$

$\begin{array}{lll}.05 & .20 & .50\end{array}$

$\begin{array}{lll}.05 & .15 & .40\end{array}$

$\begin{array}{lll}.05 & .20 & .50\end{array}$

$\begin{array}{lll}.05 & .15 & .40\end{array}$

$\begin{array}{lll}.05 & .15 & .40\end{array}$

$\begin{array}{lll}.10 & .30 & .75\end{array}$

$\begin{array}{lll}.05 & .15 & .40\end{array}$

$\begin{array}{lll}.05 & .20 & .50\end{array}$

These are distinct from the ordinary Lettuce, and much liked on account of their crisp, tender quality. They produce long, narrow leaves, blanched by drawing in the outer leaves and tying.

Eclipse Cos. A perfectly distinct variety. It is the dwarfed Cos Lettuce... $\$ 0.10 \$ 0.40 \$ 1.25$ Paris White Cos, Romaine. One of the finest varieties for Summer use..... $.05 \quad .15 \quad .40$

Trianon Cos. The long, narrow leaves, which form solid heads, bleach and

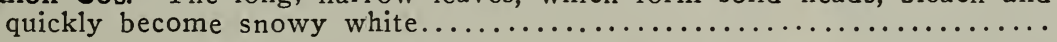

.40

$\begin{array}{lll}.05 & .15 & .40 \\ .05 & .15 & .40\end{array}$

$.05 \quad .20 \quad .50$

\section{E L O N, M U S K.}

One ounce will plant 80 hills.

After all danger of frost is over and the $g$-ound has become warm and dry, plant in hills 4 to 6 feet apart each way, 6 to 12 seeds to a hill. When up, and all danger of insects has passed, pull out all but three plants. Cultivat? until the vines cover the ground.

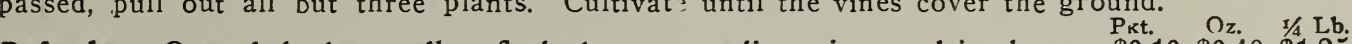

Defender. One of the best yellow-fleshed sorts; medium size, oval in shape.. $\$ 010 \$ 0.40 \$ 1.2$ J

Emerald Gem. Small, early; dark green skin, orange flesh; very sweet...... $.05 \quad .15 \quad .50$

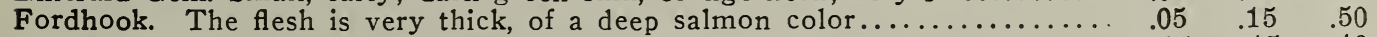

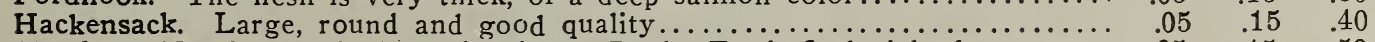

Hoodoo. Nearly round, about the size of Rocky Ford; flesh rich, deep orange $\quad .05 \quad .15 \quad .50$

Jenny Lind. Small, green-fleshed; very early; good quality................. $.05 \quad .15 \quad .50$

Long Island Beauty. The earliest and finest in quality; green flesh ................

Marshall's Matchless. A grand, new variety (see novelties) ...................... $\quad .15 \quad .40$

Montreal Market. Large, round-netted; flesh thick and light green; late.......... $\quad .05 \quad .15 \quad .50$

Netted Gem, Round. Very early; small and of fine flavor; green flesh.... $\quad .05 \quad .15 \quad .40$

Orange Christina. Round, very sweet and very early; orange flesh....... $\quad .05 \quad .15 \quad .40$

Paul Rose. Oval; rich orange flesh; very sweet...................... $.05 \quad .15 \quad .50$

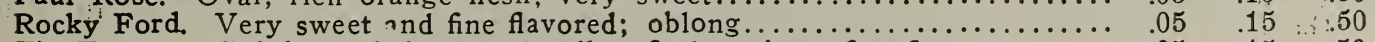

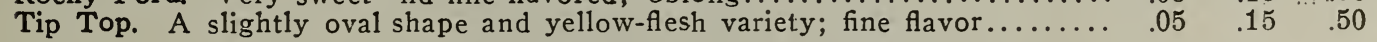

\section{ENGLISH FORCING VARIETIES.}

Blenheim Orange. Scarlet fleesh....... Per Pkt. $\$ 0.25$

Diamond Jubilee. Greenish, white flesh. .25

Hero of Lockinge White flesh. ..... .25

Invincible Scarlet. Deep scarlet flesh... .25

King George. Scarlet flesh............ .50
Royal Sovereign. White flesh tinged green $\$ 0.25$ Sutton's A1. Scarlet flesh..............25 Sutton's Emerald Gem. Green flesh........25 Sutton's Royal Jubilee. Green flesh..... .25 Superlative. Scarlet flesh...............25 


\section{E L O N, W A T E R.}

One ounce will pl int about 30 hills.

Plant in hills as directed for Musk Melons, and treat in all respects the same, except that the hills should be 8 to 10 feet apart.

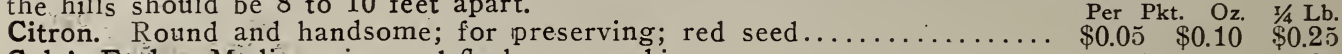

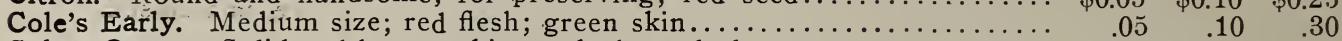

Cuban Queen. Solid and heavy; skin marked regularly ..................

Florida Favorite. A superior strain; oblong; green white stripes.........

Fordhook, Early. Flesh bright red; very sweet..................... $\quad .05 \quad .15 \quad .40$

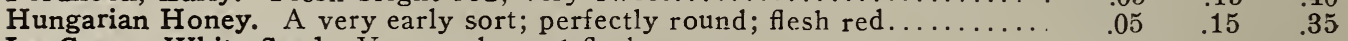

Ice Cream, White Seed. Very early; red flesh........................ $\quad .05 \quad \begin{aligned} & .05 \\ & .25\end{aligned}$

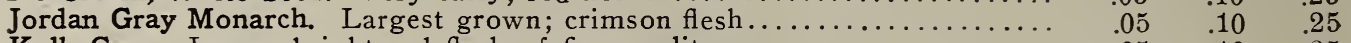

Kolb Gem. Large; bright red flesh of fine quality...................

Mammoth Iron-Clad. Light green skin, striped dark green............

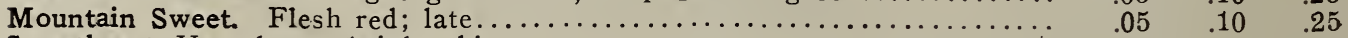

Sweetheart. Very large; bright skin............................. $\quad .05 \quad .10 \quad .25$

\section{US H R O O M P A W N .}

10 pounds will spawn about 10 feet square.

Mushroom beds may be made in a warm, dry cellar, or in any building where the frost does not penetrate, and in the open air during the Summer and Fall months. Having procured the spawn, the next thing to be attended to is to make preparation for the beds. About a fortnight or three weeks before the beds are to be made collect a quantity of fresh horse manure

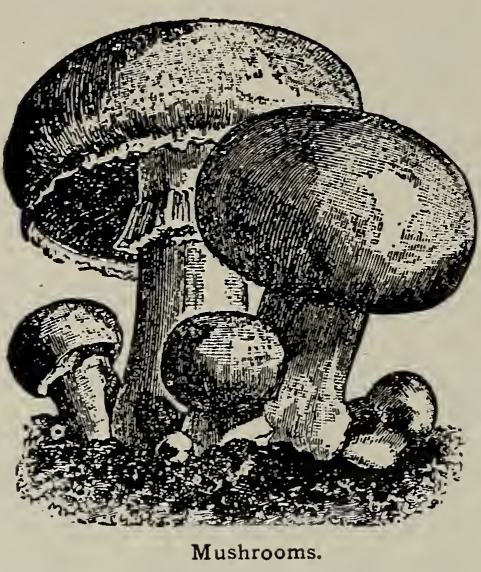
without the straw; place it in a heap under cover, and as it heats keep turning it over once or twice a week, until the fiery heat has become exhausted, which will require from ten to fourteen days time. When the manure is in a condition to be made up, lay out your bed according to your requirements, say three feet wide, ten feet long, and and from two to three feet deep, beat it down well with the back of the spade as the process of building goes on. When the bed has been made some time, say a week or thereabouts, and the heat sufficicntly declined to a temperature of 65 or 75 degrees, the spawn may be put into it. Break the spawn in pieces two inches square, and put them six inches apart, all over the bed; then cover the bed with two inches of rich soil, the stronger the better, but of a loamy quality, beating it down firmly with a spade. The soil used for this purpose should be in pliable condition, and not too wet or over-dry. Cover the bed with a foot of dried straw or hay; examine once a week to see if the manure is not heated while in this condition; if so, it will destroy the spawn, and necessitate spawning a second tme. If everything goes on well, you may expect mushrooms in about five or six weeks. When the soil looks dry, give a gentle watering with tepid water, using a rose on the watering pot. If the beds are made out-of-doors, protect them from the rain by covering them with shutters or sashes. Good crops of mushrooms can be obtained by spawning the hot-beds in Spring. They can also be raised in pots, boxes or anything capable of keeping the materials together, and placed in a cellar, closet or green-house.

Marshall's English Spawn. Per brick, 18 cts.; 10 bricks, $\$ 1.50$; per 100 bricks, $\$ 12.00$.

Pure Culture Spawn (American). Per brick, 20 cts.; 10 bricks, $\$ 1.75 ; 50$ bricks, $\$ 7.50$. If by mail, add 5 cts. pn $\mathrm{r}$ brick for postage.

\section{U S T A R D.}

One ounce will sow 75 feet of drill.

For early crops the seed may be sown in a hot-bed in March, and for general crop at frequent intervals through the Spring, in drills from 8 to 12 inches apart.

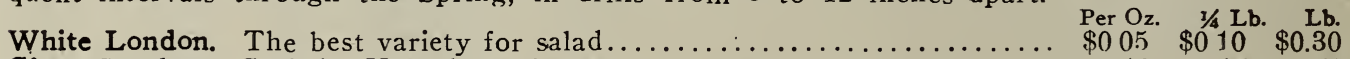

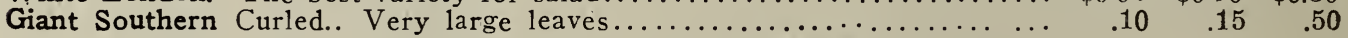

\section{OKRA OR GUMBO.}

\section{One ounce will plant 100 hills.}

This plant is extensively cultivated for its green pods. which are used in soups and stews, and are very wholesome and nutritious. Sow about the middle of May in drills 3 feet apart, and thin out the plants to 1 foot apart.

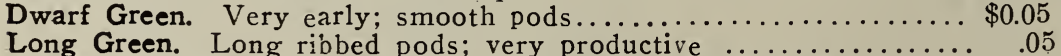

Perkin's Improved. Pods very tender, long, and deep green.......... .05

$\mathrm{Oz.} \quad \mathrm{I} / \mathrm{Lb}$. $\mathrm{Lb}$.

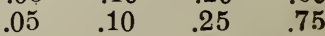

$\begin{array}{lllll}\text { White Velvet. Tender white pods; smooth and velvety in appearance } & .05 & .10 & .25 & .75\end{array}$ 


\section{O N I O N.}

Ozis ounce will sow 100 feet of drill.
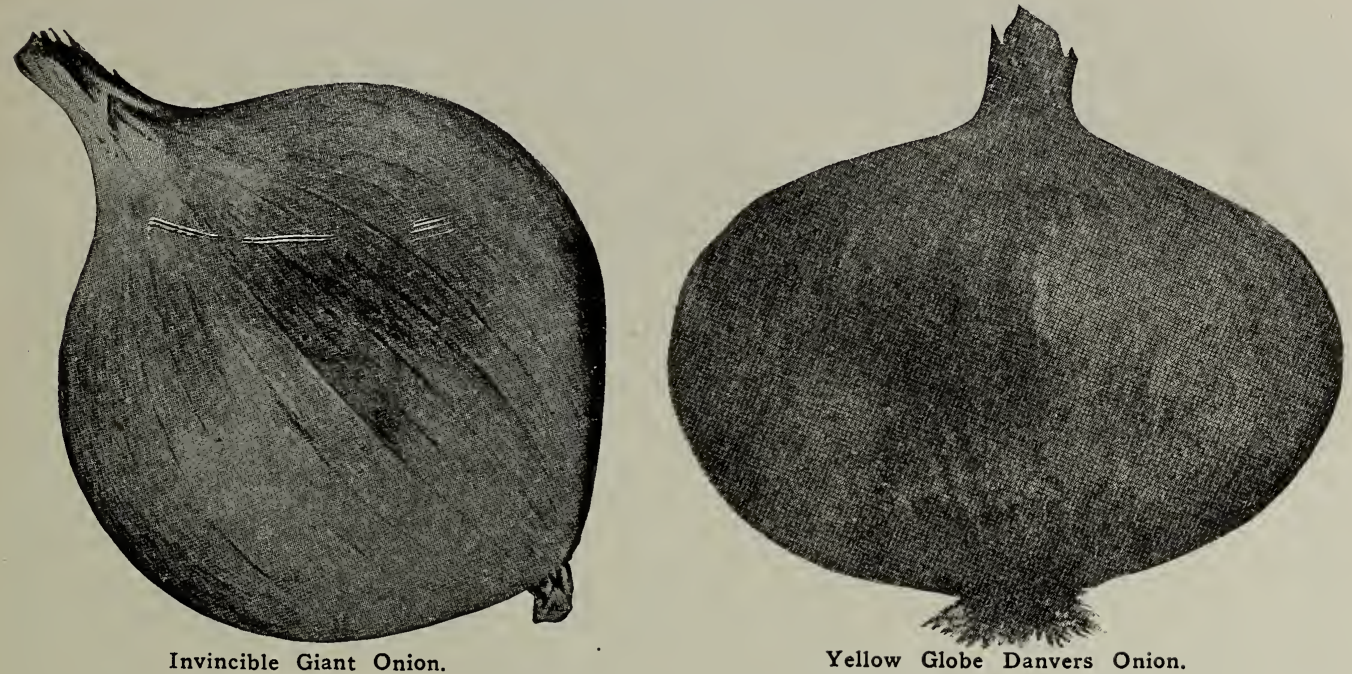

Sow in drills 1 foot apart and cover about one-third of an inch, treading or rolling after sowing so that the hot dry atmosphere may not destroy the sprouting seed. When 3 inches high thin to 2 inches apart. Stir the ground freely without disturbing the young plants and keep free from weeds.

Red Large Globe (Southport Strain). The finest large red sort... Per Pkt. Oz. $\quad 1 / 4 \mathrm{Lb}$

Red Early Flat. Medium size; very early; deep red; mild flavor . . . . . . . . . $\quad .05 \quad .20 \quad 60$

White Queen. Pure white small, fat; fine for pickling

White Large Portugal. The large flat sort of the New York markets......

White Large Globe (Southport Strain). Very large and handsome......... $\quad .05 \quad \begin{array}{llll}.30 & 1.00\end{array}$

White Mammoth Garganus, or Silver King. Large silvery white. . . . . . . . $\quad .05 \quad .20 \quad .60$

White Tripoli. Large white Italian variety ............................. $05 \quad \begin{array}{ll}20 & 60\end{array}$

White Welsh. The leaves are used for salad early in Spring. Sow in Fall.... $\quad \begin{array}{llll}.05 & .20 & .60\end{array}$

Yellow Ailsa Craig. The skin is a pale straw color and oval in shape; excel-

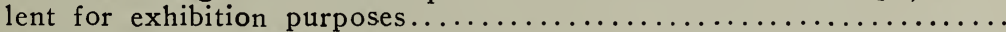

Yellow Cranston's Excelsior. Inclined to globular in shape and of a beautiful

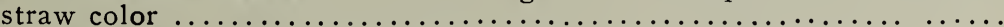

Yellow Danvers. A round standard sort; early and a good keeper...........

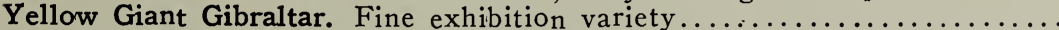

Yellow Globe Danvers (Southport Strain). Of more globular shape; keeps

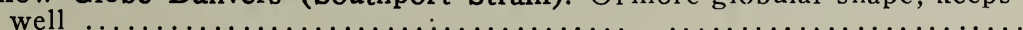

Yellow Invincible Giant. New (see novelties) $\ldots \ldots \ldots \ldots \ldots \ldots \ldots \ldots \ldots$

Yellow Prizetaker. Immense size; globe shaped ....................

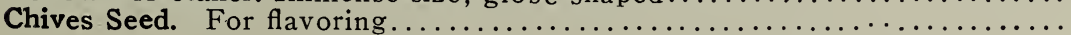

$.10 \quad .50 \quad 1.50$

$.10 \quad .50 \quad 1.50$

$.05 \quad .20 \quad .60$

$.05 \quad .20 \quad .60$

$.05 \quad .25 \quad .75$

$.25 \quad 1.50$

$.05 \quad .25 \quad .75$

$.25 \quad 1.50 \quad \cdots$

\section{ONION SETS.}

Three quarts will plant 100 yards of row.

Onion Sets should be planted early in the Spring in rows 12 inches apart, placing the sets 4 inches apart in the row. When raised from sets, the onion can be used in the green state in June, or they will be matured by July.

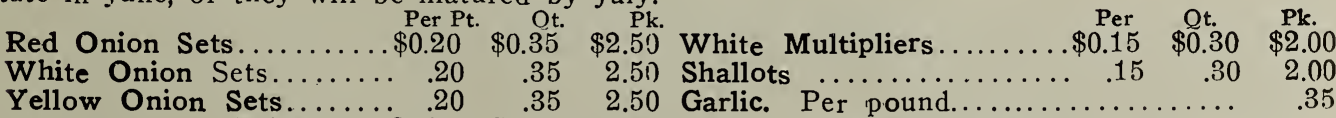

Prices of Onion Sets are su'ject to market changes.

\section{ORACH, OR FRENCH SPINACH.}

Sow early in Spring; cultivate and use like Spinach.

Red. Distinct; dark red leaves.

Per Pkt. Oz. $\quad 1 / 4 \mathrm{Lb}$.

................... $\$ 0.05 \quad \$ 0.15 \quad \$ 0.35$

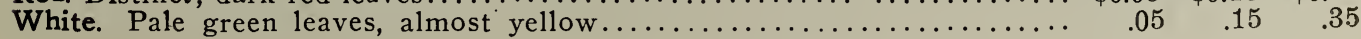




\section{P A R S L E Y.}

One ounce will sow 150 feet of row.

Sow as early as possible in Spring, first soaking the seed three hours in water; cover lightly, raking the soil fine and level on top. The drills should be about 15 inches apart. The plants appear in two to four weeks. Thin to 3 inches apart.

Marshall's Dwarf Perfection. A dwarf and compact Parsley of bright green

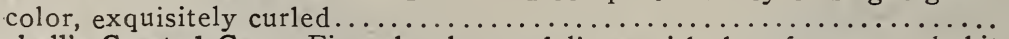
Marshall's Crested Gem. Fine closelv cut foliage with dwarf compact habit Extra Double Curled. A beautiful curled dwarf variety................... Moss Curled. A distinct variety; beautifully crimped and curled............. Hamburg, or Rooted. Grown for its roots which are used in flavoring soups

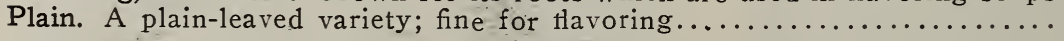

\begin{tabular}{rrr} 
Per Pkt. & Oz. & \multicolumn{1}{c}{ / Lb. } \\
& & \\
$\$ 0.10$ & $\$ 0.35$ & $\$ 1.00$ \\
.10 & .50 & 1.50 \\
.05 & .10 & .35 \\
.05 & .10 & .35 \\
.05 & .10 & .25 \\
.05 & .10 & .20
\end{tabular}

\section{P A R S N I P.}

One ounce will sow 200 feet of drill.

Sow Parsnip seed as early in Spring as the weather will permit, in drills from 15 to 18 inches apart, covering with fine soil to the depth of half an inch. The soil should be rich and deep; manured if possible, the previous Autumn. Thin out the young plants to about 6 inches apart and keep the surface of the ground open and free from weeds. It is perfectly hardy and may remain in the ground through the Winter. Indeed, the fine sugary flavor is only perfected by a severe frost.

Marshall's Marrow. A grand selection, clean white long roots; fine Per Pkt. Oz. $1 / 4 \mathrm{Lb}$ Lb.

for exhibition and family use. The finest stock in this country.. $\$ 0.10=\$ 0.20 \quad \$ 0.50 \quad \$ 1.50$

American Hollow Crown. Long, smooth and milky white ....... $.05 \quad .10 \quad .25 \quad .75$

$\begin{array}{lllllll}\text { Early Round. Adapted to shallow soils; early and good flavor........ } & .05 & .10 & .20 & .75\end{array}$

\section{P E A S .}

One quart will plant about 125 feet of drill.

Peas mature earliest in a light, rich soil; for general crop a rich loam is the best. When grown in gardens sow in double rows 6 to 8 inches apart, the rows 2 to 4 feet apart, the tall one requiring brush. Commence sowing the extra early varieties as early as the ground can be worked in February or March, and continue for a succession every two weeks until July.

\section{EXTRA EARLY PEAS.}

Gradus. The finest extra-early Pea, ripening as early as our extra-early round varieties. The pods are very large and well filled with large wrinkled deep green peas.............

Laxtonian. Very large, dark green, curved pods and Peas of finest flavor; great yielder; very early...................

Little Marvel. A few days earlier than Nott's Excelsior and with larger pods. Remarkably prolific...................

Thomas Laxton. Ripens within a day or two of the earliest round varieties and is very productive. The pods are large and contain 7 or 8 large wrinkled peas of the finest flavor..

Marshall's Extra-Early Market. A standard extra early Pea; productive and profitable to grow................... 2

Alaska. One of the very earliest blue Peas; quite productive...

Daniel O’Rourke Improved. Extra early; favorite market-garden

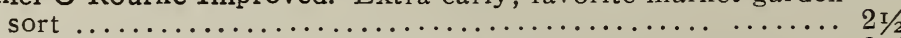

First of All. Selected strain of extra earlies................ $21 / 2$

Duke of York. Very large, long, full pods, and peas of fine flavor

Nott's Excelsior. Splendid early wrinkied sort; very prolific.... in $\begin{array}{lll}\text { Height } & 1 / 2 \\ \text { in Feet } & \text { Pint Pint Quart } 1 / 2 \text { Peck }\end{array}$ $3 \quad \$ 0.15 \quad \$ 0.25 \quad \$ 0.50 \quad \$ 1.75$

Sutton's Excelsior. An extra-early dwarf wrinkled Pea; pods filled with large peas of the finest flavor, and produced in

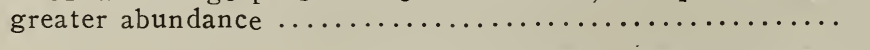

$\begin{array}{ccccc}1 \mathrm{I} / 2 & .15 & .25 & .50 & 1.75 \\ 2 & .10 & .20 & .45 & 1.50 \\ & & & & \\ 3 & .15 & .25 & .50 & 1.75 \\ 21 / 2 & .10 & .20 & .35 & 1.25 \\ 21 / 2 & .10 & .15 & .30 & 2.00 \\ 21 / 2 & .10 & .15 & .30 & 2.00 \\ 21 / 2 & .10 & .15 & .30 & 2.00 \\ 3 & .10 & .15 & .30 & 2.00 \\ 1 & .10 & .20 & .40 & 1.50 \\ \vdots & & & & \\ 1 & .10 & .20 & .40 & 1.50 \\ & & . & & \\ 4 & .15 & .30 & .60 & 2.25 \\ 2 & .15 & .30 & .60 & 2.25 \\ & & & & \\ 3 & .15 & .30 & .60 & 2.25 \\ 3 & .20 & .40 & .75 & 2.50 \\ 5 & .25 & .50 & 1.00 & 3.50\end{array}$

Boston Unrivaled. An extraordinary productive, second early

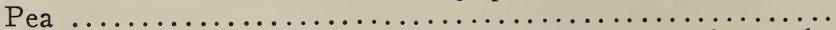

Kelway's Beauty. Of Gradus type, but so hardy that it can be sown much earlier and picked before that variety...........

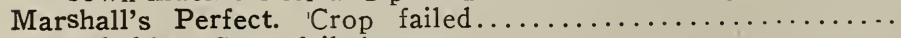

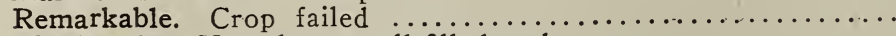

The Leader. Very large well filled pods ...................

Senator. One of the best curved podded main crop varieties.....
Marshall's Warrior. A grand new Pea of the Duke of Albany type. Very productive, well filled pods and fine flavor.... 


\section{PEAS-Continued. MEDIUM EARLY PEAS.}

Thampion of England. Well-known standard variety. Sow thickly $\begin{gathered}\text { Height } \\ \text { in Pint }\end{gathered} \stackrel{1 / 2}{\text { Pint }}$ Quart $1 / 2$ Peck

Daisy or Dwarf Telephone. A dwarf variety bearing handsome pods resembling stratagem ....................... 1 r $/ 2 \quad .15 \quad .25 \quad .50 \quad 1.75$

Dwarf Champion or.Juno. Dwarf form of the popular Cham-

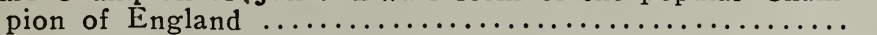

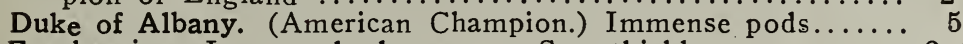

Everbearing. Long pods, large pea. Sow thickly.......... $21 / 2$

Heroine. Large full pods; enormously productive........... $2 \mathrm{r} / 2$

Horsford's Market-Garden. On the style of Advancer; very prolific ................................... $21 / 2$

McLean's Advancer. A fine standard sort of excellent quality $21 / 2$

Prince Edward. Branching habit, large pods filled with peas

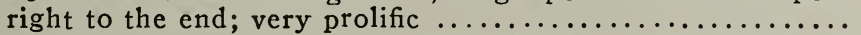

MAIN CROP PEAS.

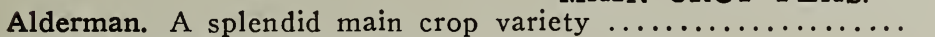

Stratagem. Very large pods; peas of first quality.............. $11 / 2$

Telephone.. Enormous pods and peas of best quality....... 4

Telegraph (L. I. Mammoth). Large pods and Peas; excellent.. 4

White Marrowfat. A favorite; heavy yielder.............. 4

Black-Eyed Marrowfat. Very hardy and prolific; for market...

\section{SUFAR PEAS (Edible Pods.)}

Sugar Peas have edible pods which are eaten when young. Equal in flavor to the best string beans.

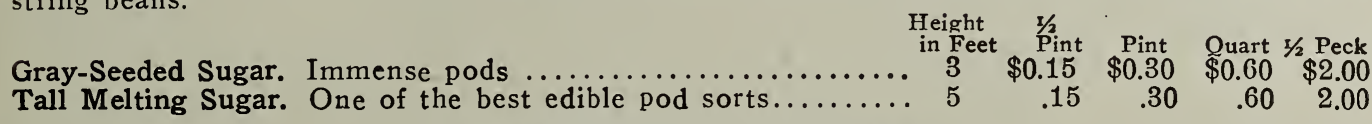

\section{FARMOGERM (For Peas).}

Peas yield earlier, longer and better crops when treated with Farmogerm. Small size, $1 / 8$ acre, 25 cts. Garden size, 1-4 acre, 50 cts.

\section{P E P P E R}

One ounce will produce 2,000 plants.

Sow in hot-beds in March and, when the soil has become warm, set in rows 2 feet apart and 18 inches in the rows; hoe frequently. The plants may also be forwarded in small pots.

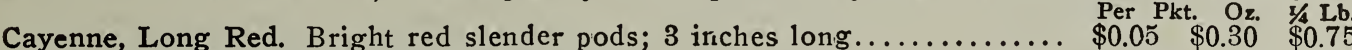

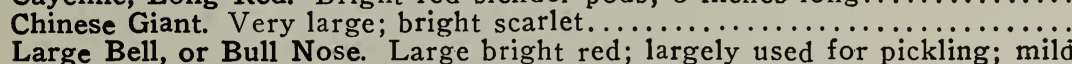

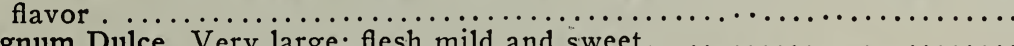

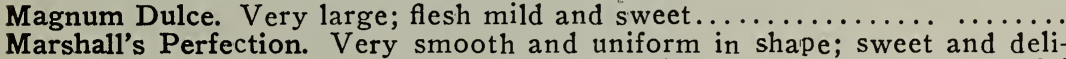
cate and entirely free from pungency. Color when ripe a beautiful

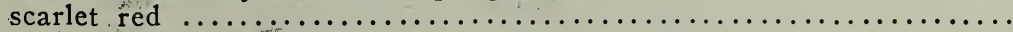
Red Chili. Very productive; very small; red and very pungent ..........

Red Cluster. A new type of Chili, with upright, bright red fruits..........

Ruby King. Bright red, 4 to 6 inches long; best for stuffing............

Sweet Mountain. Large size; regular handsome shape; mild flavor........

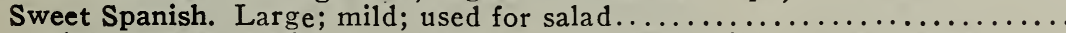

Upright Sweet Salad. Color bright scarlet; flesh mild and very sweet......

.10

.05

.10

.40

1.25

.10

.25

.50

75

\section{.10}

.05

.05

.05

.05

.05

.05

\section{P U M P K I N .}

\section{One ounce will plant 50 hills.}

The common practice is to dron two or three seeds in every second or third hill in the cornfield, but if cultivated on a large scale the seed may be sown in hills 8 feet apart each way, four plants to each hill, and otherwise treated in the same manner as melons or cucumbers.

\begin{tabular}{|c|c|c|c|c|}
\hline ecticut Field. Grown in corn-fields $f$ & & $\$ 0.10$ & 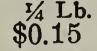 & \\
\hline haw Striped. A splendid striped crook-neck & .05 & .10 & .25 & \\
\hline y Sugar. Fine grained; small; yellow...... & .05 & .10 & .25 & \\
\hline Cheese. Flat; the best variety for small & .05 & .10 & .20 & \\
\hline King. Gro & .05 & .15 & .40 & \\
\hline Tours. A v & .05 & .10 & .25 & \\
\hline 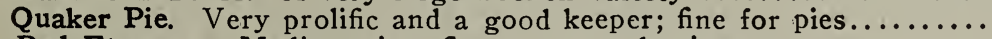 & .05 & .10 & .25 & \\
\hline es. & .05 & .15 & .40 & \\
\hline
\end{tabular}




\section{P O T A T O E S.}

\section{GROWN EXPRESSLY FOR SEED IN MAINE.}

Ten bushels cut tubers will plant one acre.

The potato, like the robust-growing vegetables, can be grown with varying success on soils of all kinds and in all conditions of fertility, but the soil best suited to it is a sandy loam. Manure is applied either in rows or hills or broadcast over the hills and ploughed in - the latter in most cases being prefera'ble. In highly enriched soils the plants are more liable to disease than when grown in soil that is naturally good. Plant as early in Spring as the ground can be had in fair working order, in hills or ridges, about three feet apart, cover lightly with soil, about 4 inches deep.

\section{EARLY VARIETIES.}

Beauty of Hebron. Slightly flesh colored skin, with pure white flesh; very productive and of the finest quality $\ldots \ldots \ldots \ldots \ldots \ldots \ldots \ldots \ldots \ldots \ldots \ldots \ldots \ldots \ldots \ldots \ldots$

Bovee. Extra early; fine quality; flesh white......................... $\quad .70$

Early Rose. Very early; fine quality; very productive................ 65 .

Early Norther. Extra earl;y very prolific; fine quality................ $.70^{\circ}$

Early Puritan. An early white-skinned variety; very productive. .......... $\quad .70$

Early Ohio. A seedling of Early Rose; tubers round; very early..........

Irish Cobbler. One of the best extra early varieties; very large white and

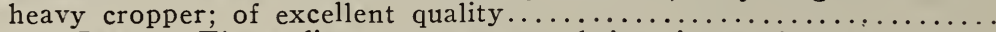

Noroton Beauty. The earliest potato grown; being sixteen days earlier than

the Early Rose; as fully productive as any main-crop or late sort......

The Thorburn. The best for first crop; very early and of fine quality......

$\begin{array}{rrr}\text { Per Pk. } & \text { Bushel } & \text { Bag } \\ \$ 0.65 & \$ 2.25 & \$ 4.50 \\ .70 & 2.50 & 5.00 \\ .65 & 2.25 & 4.50 \\ .70 & 2.50 & 5.00 \\ .70 & 2.50 & 5.00 \\ .70 & 2.50 & 5.00 \\ .70 & 2.50 & 5.00 \\ .80 & 3.00 & 6.00 \\ .70 & 2.50 & 5.00\end{array}$

\section{LATE VARIETIES.}

Carman No. 1. A recognized standard sort the world over........... $\quad .70 \quad 2.50 \quad 5.00$

Carman No. 3. Reliable, large oblong, slightly flattened................ $\quad .70 \quad 2.50 \quad 5.00$

Green Mountain. Oval shape; white skin and flesh; heavy yielder......... $\quad .65 \quad 2.25 \quad 4.50$

$\begin{array}{llllll}\text { Rural New Yorker. Very few and shallow eyes; pure white skin and flesh.. } & .70 & 2.50 & 5.00\end{array}$

Sir Walter Raleigh. The flesh is white and fine grained; heavy cropper.... $\quad .70 \quad \begin{array}{lllll}7.50 & 5.00\end{array}$

$\begin{array}{lllll}\text { White Elephant. Late, large, good quality and very productive............ } & .70 & 2.50 & 5.00\end{array}$

Uncle Sam. Handsome shape; good size; fine quality .................. $\quad .70 \quad 2.50 \quad 5.00$

The Woodruff. A new oblong white main-crop variety ................. $65 \quad 2.25 \quad 5.00$

Prices of potatoes are subject to market changes. Potatoes are forwarded by express or freight as directed, puchaser paying charges.

\section{RADISH.}

One ounce of seed will sow 100 feet of drill.

Radishes require a light, loamy so1l, moderately fertile, which should be deeply dug and well pulverized. 'The situation should be warm and sheltered. For an early supply sow in January or February in hot-beds, keeping well ventilated. In May they may be sown out-of-doors. Successive sowings should be made every two weeks. Radishes to be crisp and tender should make a rapid growth.

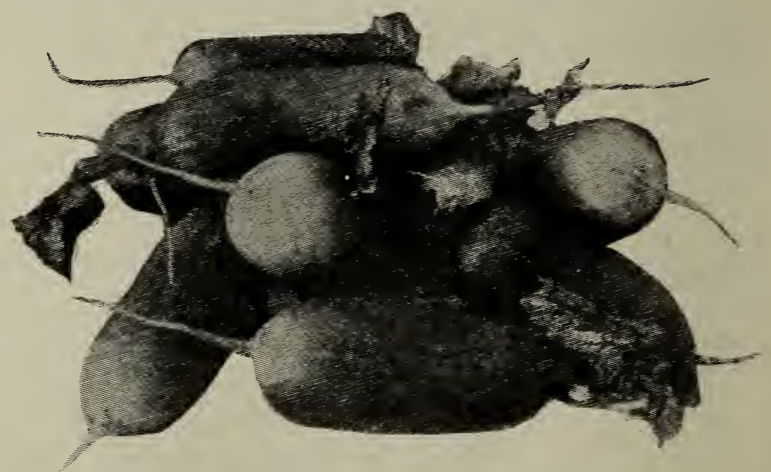

Olive-Shaped French Breakfast Radish.

\section{FORCING VARIETIES.}

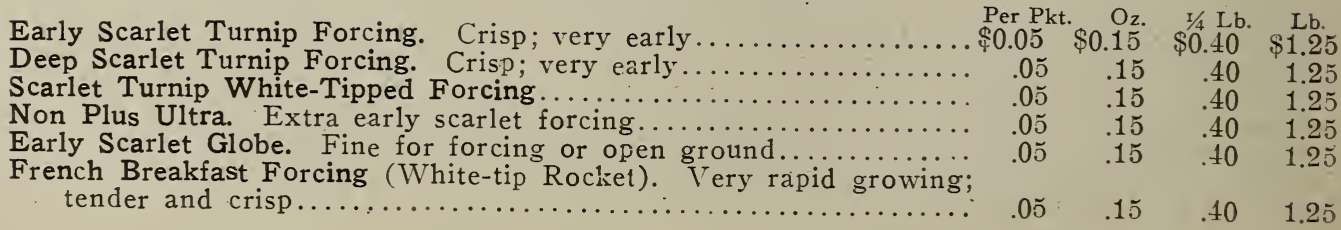




\section{RADISH-Continued. OUTDOOR VARIETIES.}

Turnip, Marshall's Perfection (see novelties)

Per Pkt. $\mathrm{Oz}$.

Turnip, Early Scarlet. Very early. The French favorite. . . . . . . . . .05

Turnip, Scarlet White-Tipped. Very early for frames or out doors.. .05

.10

$\$ 1 / 4$ Lb. $\$$ Lb.

Turnip, Early White, or Box. Flesh pure white and sweet.........

Turnip, Crimson Giant. Suitable for forcing or out doors; flesh very

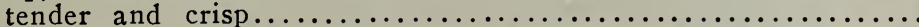

Turnip, Triumph (Speckled Beauty). Very prettily striped or mottled

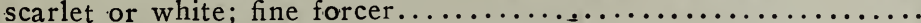

Turnip, Large White Summer. Of largee size; roundish shape......

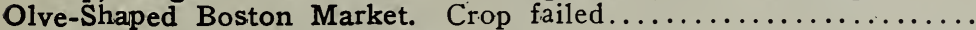

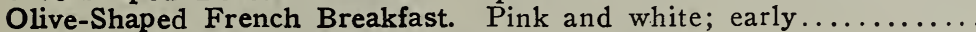

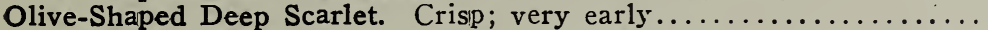

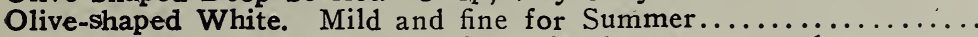

Long Scarlet Short Top. Very long; for frames or out doors.......

Long White Vienna, or Lady Finger. Crisp and tender in Summer..

Long Icicle. Pure white; of fine flavor; suitable for forcing. ...........

Winter Long Black Spanish. The popular Winter sort...........

Winter Half-long Black Spanish. Very fine strain.............

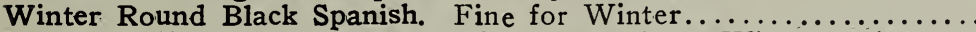

Winter California White Mammoth. A very large Winter variety...

Sakurajima (Mammoth Japan). The largest sort in cultivation...

\section{R H U B A R B .}

$.05 \quad .10 \quad .25 \quad .75$

$\begin{array}{llll}.05 & .10 & .30 & 1.00\end{array}$

$\begin{array}{llll}.05 & .10 & .30 & 1.00\end{array}$

$\begin{array}{llll}.05 & .10 & .25 & .73\end{array}$

$\begin{array}{llll}.05 & .10 & .25 & .75\end{array}$

$\begin{array}{llll}.05 & 10 & 25 & 75 \\ .05 & .10 & .30 & 1.00\end{array}$

$\begin{array}{llll}.05 & .10 & .30 & 1.00\end{array}$

$\begin{array}{llll}.05 & .10 & .25 & .75\end{array}$

$\begin{array}{llll}.05 & .10 & .25 & .75\end{array}$

$\begin{array}{llll}.05 & .10 & .25 & .75\end{array}$

$\begin{array}{llll}.05 & 10 & .25 & .75\end{array}$

$\begin{array}{llll}.05 & .10 & .25 & .75\end{array}$

$\begin{array}{llll}.05 & .10 & .25 & .75\end{array}$

$\begin{array}{llll}.05 & .10 & .25 & .75\end{array}$

$\begin{array}{llll}.05 & .10 & .25 & .75\end{array}$

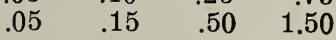

One ounce will produce 1,000 plants.

Sow in April in drills 18 inches apart. When the plants are strong enough, thin out to 6 inches. In the Fall or following Spring, transplant the roots into deep, rich soil, 3 feet apart each 'wav.

Victoria. Very large; later than the Linnaeus. Per pkt., 5c; oz., 20c; $1 / 4$ 1b., 50c; lb. $\$ 2.00$.

Rhubarb Roots. Extra strong. Each, 15c; doz., $\$ 1.50$; per $100, \$ 10.00$

Rhubarb Roots. For forcing. Each, 25c.; doz. \$2.50; per 100, $\$ 20.00$.

\section{SALSIFY, OR OYSTER PLANT.}

One ounce will sow 50 feet.

A most delicious vegetable. It is used stewed, boiled, or fried, and sometimes as a salad. When cooked it has an oyster flavor. Cultivate the same as for carrots or parsnips.

Per Pkt. Oz. 1/4 Lb.

Long White French. Delicious when cooked; roots of medium size......... $\begin{array}{rrr}\$ 0.05 & \$ 0.20 & 0.60\end{array}$

Long Black, or Scorzonera. Resembles long white, but black............ $\quad .05 \quad .25 \quad .75$

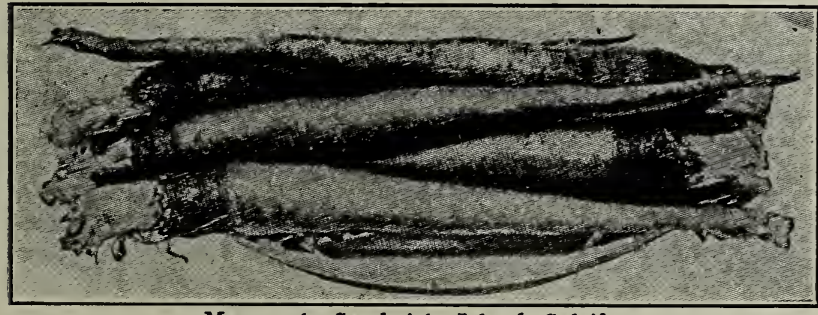

Mammoth Sandwich Island Salsify.

SPINACH.

One ounce will sow 100 feet of drill, $1 \mathrm{C}$ to $12 \mathrm{lbs}$. an acre.

This is best developed and most tender and succulent when grown in very rich soil. For Summer use sow early in Spring in drills 15 inches apart, and make successive sowings every two weeks. For Spring use sow in September, and cover lightly in November with light litter.

New Zealand. Makes a low spreading plant from which delicious, Per Pkt. Oz. $\quad$ I/4 Lb. Lb. tender greens can be gathered the entire Summer. May be started in a hotbead and transplanted or sown out-of-doors when the ground is warm, allowing two feet between the plants......... $\$ 0.05$

Long Standing. Of delicious, tender quality; dark green........... ${ }_{0} .05$

Savoy-Leaved, or Bloomsdale. Large, tender curled leaves........... .05

$\$ 0.10 \quad \$ 0.30 \quad \$ 1.00$

$\begin{array}{lrr}.10 & .20 & .70\end{array}$

Round Thick-Leaved. The variety in most general use; equally good

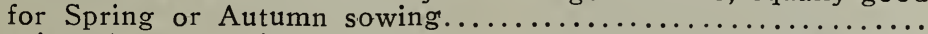

Victoria. A new variety with thick dark-green leaves. Best long

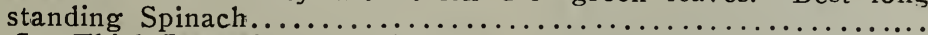

Viroflay Thick-Leaved. A standard sort, equally good for early Spring or Fall sowing; leaves are thick, succulent and tender............

Prickly, or Winter. Vigorous and hardy; recommended for Fall sowing Owing to war conditions in Europe the prices of Spinach are subject to $\frac{.10}{.20}$

$\begin{array}{llll}.05 & .10 & .20 & .70\end{array}$

$\begin{array}{llll}.05 & .10 & .20 & .70\end{array}$

$\begin{array}{llll}.05 & .10 & .20 & .70\end{array}$

$\begin{array}{llll}.05 & .10 & .20 & .70\end{array}$ 


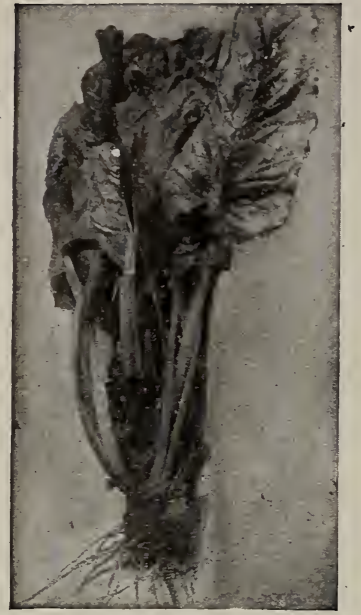

Swiss Chard.

\section{S O R R E L.}

One ounce will sow 150 feet of drill.

Used cooked as spinach or to mix with salads. Sow in shallow drills 12 inches apart, and thin out the young plants to 6 inches

Large-Leaved French. Pkt., 5c; oz., 15c; 1/4 1b., 40c; 1b., $\$ 1.25$.

\section{SWISS CHARD, OR SPINACH BEET.}

This Beet produces leaves only; excellent as greens. Cultivate same as Spinach, sowing the seed in early Spring, in drills $11 / 2$ feet apart. Good cultivation will increase the delicacy and tenderness of the leaves.

Swiss Chard. Pkt., 5c; oz., 10c; 1/4 1b., 30c.; 1b., $\$ 1.00$.

Giant Lucullus. Pkt., 5c.; oz., 15c.; 1/2 lb., 40c.; lb., $\$ 1.00$.

\section{S Q U A S H .}

One ounce Early Squash will plant about 25 hills.

One ounce Marrow Squash will plant about 50 hills.

The squash succeeds best in good rich soil. It is not advisable to plant before May 15th Sow in hills in the same manner as cucumbers and melons. Use seed freely, 8 to 12 seeds to the hill, to provide for losses by insects.

\section{BUSH VARIETIES.}

Improved Early White Bush Scallop. A good early shipping variety...... Giant Summer Crookneck. Double the size of Summer Crookneck...........

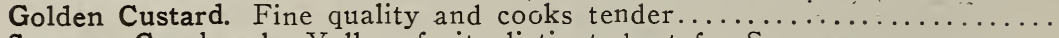

Summer Crookneck. Yellow fruit; distinct; best for Summer...............

Silver Custard. A mammoth strain of the Early White Bush...............

Cocozell Bush. A fine variety; oblong shape; skin smooth, dark green,

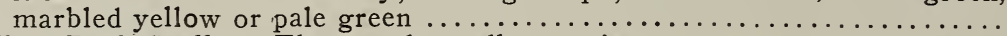

Yellow Bush Scallop. The popular yellow variety $\ldots \ldots \ldots \ldots \ldots \ldots \ldots \ldots$

\begin{tabular}{crr} 
Per Pkt. Oz. & \multicolumn{1}{l}{$\mathrm{I}_{4} \mathrm{Lb}$} \\
$\$ 0.05$ & $\$ 0.10$ & $\$ 0.25$ \\
.05 & .10 & .30 \\
.05 & .10 & .30 \\
.05 & .10 & .30 \\
.05 & .10 & .30 \\
& & \\
.05 & .15 & .40 \\
.05 & .10 & .25
\end{tabular}

\section{RUNNING VARIETIES}

Boston Marrow. Oval; bright orange; flesh yellow and fine.......... $\$ 0.05$

Delicious. Green skin; orange flesh; fine grained; sweet and dry...........

Essex Hybrid. A good Fall and Winter sort........................ 05

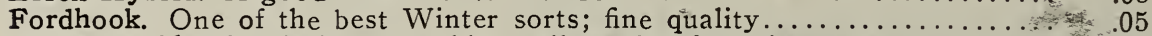

Golden Hubbard. Flesh deep golden yellow fine for private use.......... 05

Hubbard. Well known and liked for late use..........................

Mammoth Chili. Rich orange flesh; grows to an enormous size...........

Marblehead. Gray skin; very productive; fine keeper ................

Orange Marrow. Quite distinct; very early and of most delicate flavor...... $\quad .05$

Perfect Gem. Round, white, fine quality; good for Fall or Winter.......... .05

Winter Crookneck. One of the best Winter sorts..................... $\quad .05$

Vegetable Marrow. A favorite English sort; skin greenish yellow; flesh white

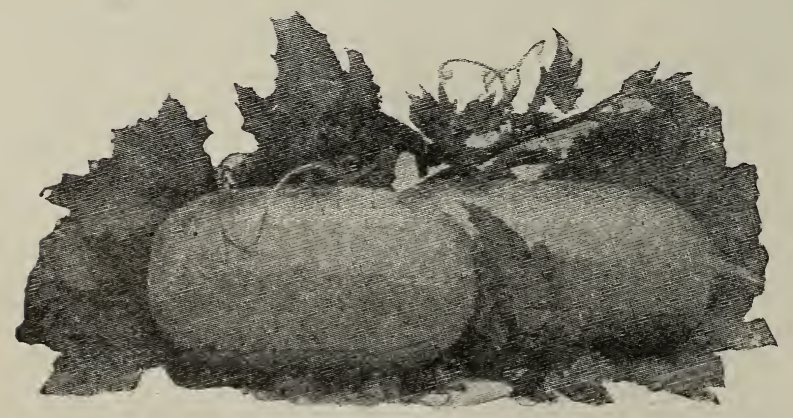

White Bush Vegetable Marrow.

\section{ENGLISH VEGETABLE MARROWS.}

The following varieties are well adapted for growing in this climate.

Long Green Bush. Fruits Pkt. Uz. long pale flavor ...........\$0.10 $\$ 0.30$

Long White Bush. Creamy white; very prolific.... $.10 \quad .30$

Long Cream. Very long, pale cream color; trailing sort. ............. 10 


\section{T O B A C C O S E E D.}

One ounce will produce plants for one acre.

Connecticut Seed Leaf. Suitable for growing in these latitudes; used for cigar wrappers. Pef pkt. 5 cts; ounce, 30 cents; $1 / 4$ pound, $\$ 1.50$.

Imported Havana. Per pkt., 10 cents; ounce, 10 cents; $1 / 4$ pound, $\$ 1.50$.

\section{T O M A T O}

One ounce will produce 1,000 plants.

Sow thinly about the first week in March in hot-bed, greenhouse, window or sitting room, where the temperature is never below 60 degrees. When two inchs high set out the plants in boxes about 4 inches apart, or pot singly. About the first of June they may be transferred to the open ground. Set them deeply four feet apart.

Marshall's Prolific. The finest medium-sized tomato for forcing or outdoor planting. It is an enormous cropper, producing large clusters of bright scarlet fruit. The quality and flavor is excellent, flesh solid, having very few seeds, smooth and medium size. Pkt., 25 cts.; $1 / 4$ oz., $\$ 1.00$.

Buck's Tresco. Round, bright red, moderate size fruits; a fine forcer. Pkt., 25 cts.

Comet. Beautiful, smooth, round fruit in great abundance. Color a rich scarlet red. Equally good for outdoor culture as for forcing. Pkt.. 15 cts.

Stirling Castle. Excellent for forcing as well as out-door culture. Fruit is of medium size. Pkt., 10 cts.; $1 / 2$ oz., 5i) cts.; oz., $\$ 1.00$.

Sunrise. A fine forcing variety; rich scarlet color. Pkt., 15 cts.

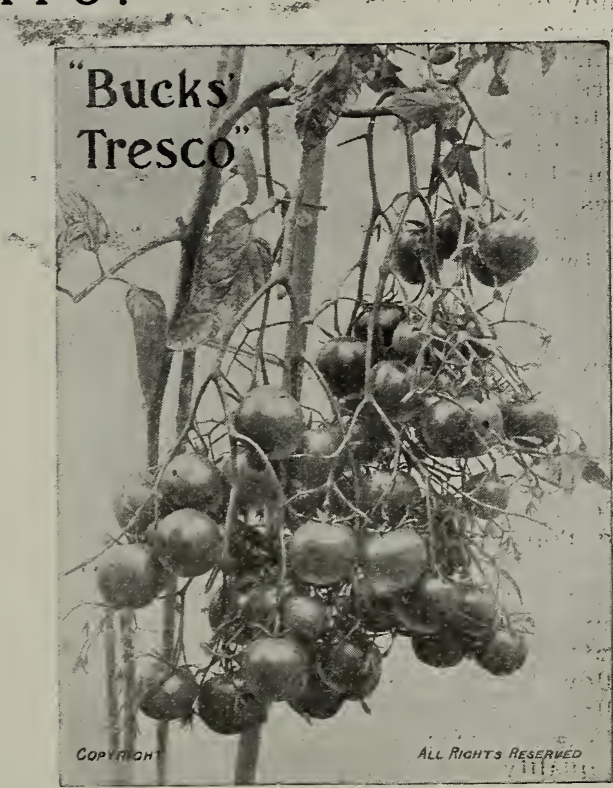

Tomato, Bucks Tresco.

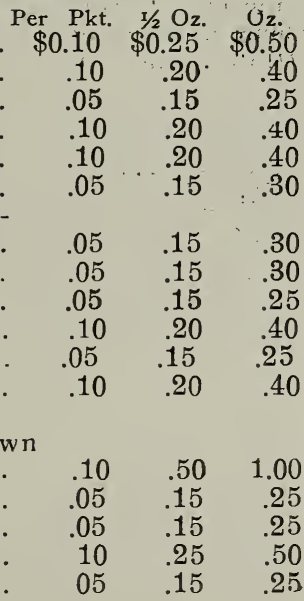

Best of All. An excellent sort for forcing or early out-door crop........ $\$ 0.10$

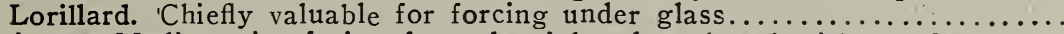

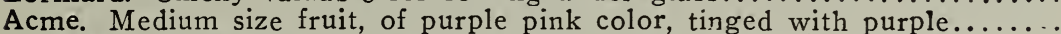

Coreless, Livingston's. Bright red, almost round and free from core......

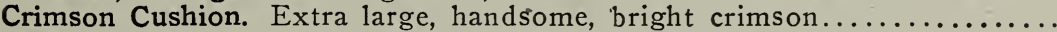

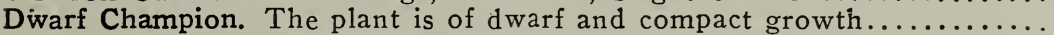

Dwarf Stone. Color bright scarlet, perfect shape; resembles Dwarf Cham-

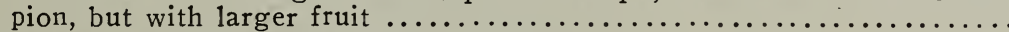

Earliana. Extra-early; bright red; smooth $\ldots \ldots \ldots \ldots \ldots \ldots \ldots \ldots \ldots \ldots \ldots$

Early Ruby. The earliest large tomato grown; rich crimson color..........

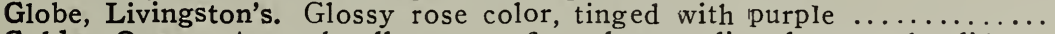

Golden Queen. A good yellow sort; first-class quality; large and solid......

June Pink. A very early sort; smooth; bright pink color; medium size.....

Marshall's National. See novelties. Per Pkt. 25 cents.

John Baer. A beautiful, brilliant red variety; perfect, solid, high crown

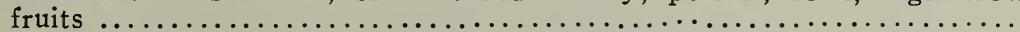

Matchless. Extra large, smooth and handsome; bright red; very solid.....

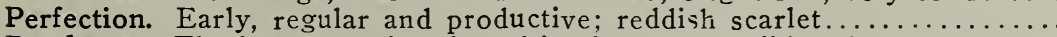

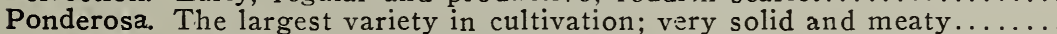

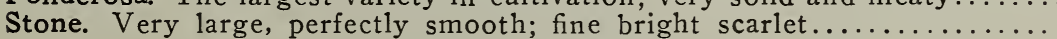

\section{SMALL-FRUITED TOMATOES.}

\begin{tabular}{|c|c|c|}
\hline Per Pkt. & 1/2 Oz. & $\mathrm{Oz}$. \\
\hline & $\$ 0.20$ & $\$ 0.4$ \\
\hline .05 & .20 & .4 \\
\hline .05 & .20 & \\
\hline .05 & .20 & \\
\hline .05 & .20 & \\
\hline 05 & .15 & \\
\hline .05 & .20 & \\
\hline .05 & .20 & \\
\hline .05 & .20 & \\
\hline .05 & .15 & \\
\hline
\end{tabular}

Red Cherry. Small fruits; used for pickles; very handsome............

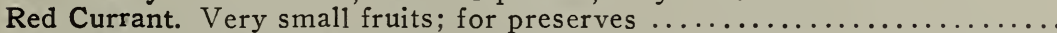

Red Peach. Resembling a peach; for preserves, pickles and exhibition......

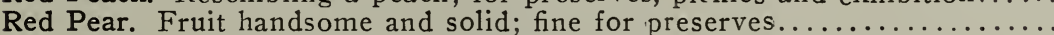

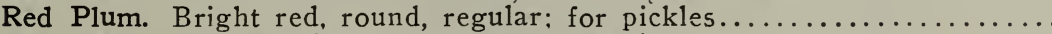

Strawberry (Winter Cherry, or Husk Tomato). Makes fine sauce..........

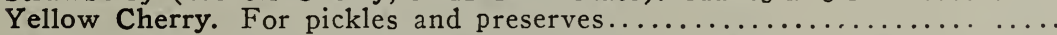

Yellow Peach. Beautiful clear yellow; perfectly resembles a peach ........

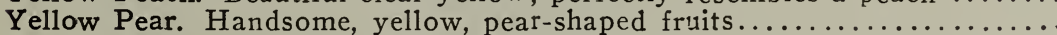

Yellow Plum. Round and regular; bright yellow................. 


\section{T U R N I P.}

One ounce will sow 150 feet of drill

Turnips do best on highly enriched, light, sandy or gravelly soil. Commence sowing the earliest varieties in April, in drills, from 12 to 15 inches apart, and thin out early to 6 or 9 inches in the rows. For a succession, sow at intervals of two weeks, until the middle of August.

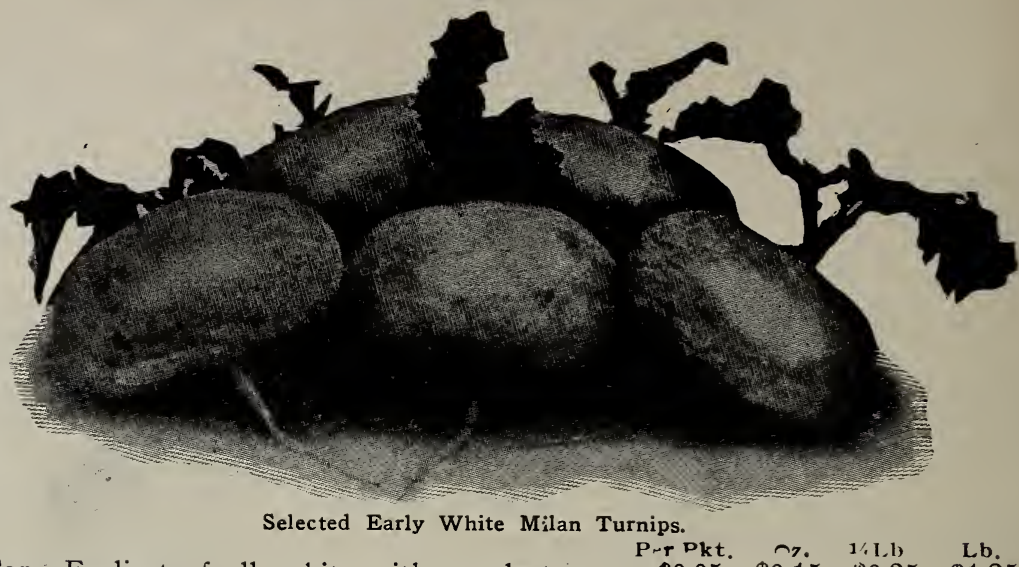

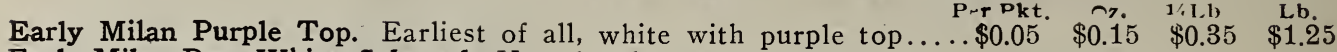

Early Milan Pure White, Selected. Very handsome, pure white and as

early as the above; flesh very sweet and tender................ $.05 \quad \begin{array}{lllll}.15 & .35 & 1.25\end{array}$

Early Snowball. Small, and rapid growth; pure white...........

Cow Horn. Long, white; in shape resembles a cow's horn .........

Golden Ball. Very handsome; keeps fairly well ................

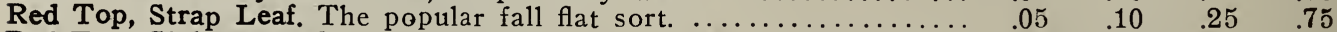

Red Top, Globe-shaped. A standard sort in the New York market... $\quad .05 \quad \begin{array}{llll}.10 & .25 & .75\end{array}$

White Egg. Oval, handsome and sweet.......................

$\begin{array}{lllllll}\text { White Strap Leaf Flat. A good early white flat sort.............. } & .05 & .10 & .25 & .75\end{array}$

$\begin{array}{llllll}\text { White French, or Rock. A very productive and a fine keeper......... } & .05 & .10 & .25 & .75\end{array}$

Yellow Globe. Good and sweet; keeps fairly well...............

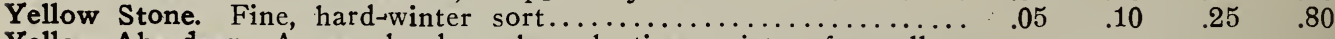

Yellow Aberdeen. A very hardy and productive variety of excellent

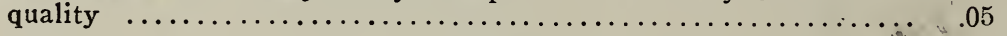

RUTA-BAGA.

American Purple Top. A strain of Purple-top yellow............. $.05 \quad .10 \quad .30 \quad 1.00$

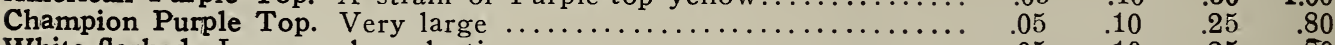

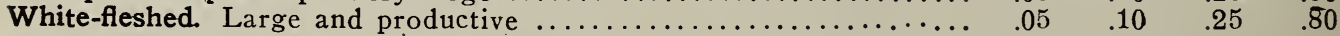

\section{HERBS-SWEET AND MEDICINAL.}

Angelica, Garden. For flavoring cakes. . ................ $\$ 0.05$

Anise. Seeds aromatic ......... .05

Balm. For culinary purposes.... .05

Basil, Sweet. Culinary herb used for flavoring soups, etc....... .05

Borage. Leaves used as a salad.. $\quad .05$

Caraway. Used in flavoring bread .05

Catnip. Has medicinal qualities. .10

Dill. Seeds used for flavoring... .05

Fennel, Sweet. Seeds aromatic: for flavoring ................

Fennel, Florence. In flavor resembling celery $\ldots \ldots \ldots \ldots \ldots$.

Hyssop. Has medicinal qualities

Horehound. Has medicinal quali-

ties $\ldots . . . \ldots \ldots \ldots \ldots \ldots \ldots \ldots \ldots . . .05$
Oz.

$\$ 0.20$

.15

.30

.20

.10

.10

.50

.10

$.05 \quad .10$

$.05 \quad .15$

$.05 \quad .20$

Lavender. For oil and distilled water .................. \$0.05 $\$ 0.15$

Marigold, Pot. Single. For medicinal purposes .............

Marjoram Pot Used in seasoning $\quad .05 \quad .15$ Marjoram, Sweet. Used in seasoning . . ....................

Mint. Peppermint ........... $\quad .25$

Rosemary. Yields an aromatic oil .05

Sage. Broad leaf. A culinary herb .05

Savory, Summer. A culinary herb .05

Savory, Winter. A culinary herb .05

Tarragon (Estragon). Used for flavoring pickles, vinegar, etc..

Thyme, Broad-leaved English. Used as a seasoning..........

.25 Wormwood. Has medicinal qualities .......................

.10

$.05 \quad .50$

$.05 \quad .25$

\section{B I R D S E D S, E T C.}

\section{Per Lb.}

CANARY, best Sicily. 5 lbs., 70 cts...\$0.15 CANARY SEED. MIXED. 5 lbs., 40c.. .10 GRAVEL FOR CAGES. Per quart, 6c.. HEMP. 5 lbs.., 40 cts................ 10 LETTUCE SEED. Oz., 5 cts.......... .25 MAW, BLUE POPPY $\ldots \ldots \ldots \ldots \ldots . .20$
MILLET. AMERICAN .5 lbs. 40 Per Lb. RAPE, GERMAN. 5 lbs., 40 cts. cts.. $\$ 0.10$ ROUGH RICE ..................... 12 SUNFLOWER SEED for Parrots, 5 lb.40c. .10 CUTTLE FISH BONE............... .50 THISTLE SEED ................. 30

Prices of Bird Seeds are subject to cha:iges of market values throughout the year. 


\section{VEGETABLE PLANTS AND ROOTS}

Artichoke Plants, Globe, Selected Large Green. Ready April 1st. $\$ 1.50$ per dozen; $\$ 12.00$ per 100.

Asparagus Roots. See page 9 .

Brussels Sprouts. Doz., 20 cts.; 100, $\$ 1.00$.

Cabbage Plants. For April and May delivery. Dozen, 20 cts.; 100, $\$ 1.00$. Delivery July and August. 100,50 cts.; 1000, $\$ 4.00$.

Cauliflower Plants. Snowball and Selected Erfurt. Pot grown; ready April and May. 30 cts. per doz.; $\$ 2.00$ per 100 .

Celery. Extra strong, transplanted plants. Delivery June and July. Doz., 15 cts.; 100, 60 cts.; 1000, $\$ 5.00$.

Chicory Roots. Strong for forcing, $75 \mathrm{cts}$. doz.; 100, $\$ 4.00$.

Chives. For flavoring. 15 cts. per clump; $\$ 1.50$ per dozen.

Egg Plants. Ready in May and June. Grown in pots, 60 cts. per doz.; $\$ 5.00$ per 100 .

Hop Vine Roots. 15 cts. each; $\$ 1.50$ per doz.

Horseradish Sets, New Bohemian. A new variety, which produces roots of enormous size and succeeds in every soil. 20 cts. per doz.; $\$ 1.00$ per 100 .

Kale or Borecole. Siberian or Curled Scotch. Dozen, 15 cts.; 100, 50 cts.

Kohl-Rabi. White Vienna. Dozen, 20 cts ; $100, \$ 1.25$.
Letíuce. Ready in April and May. Boston Market, Paris Cos. Doz., 20 cts.; 100, $\$ 1.00$. Mint. Strong roots. Each, 15 cts.; doz, $\$ 1.50$. Peppers. Ready in May and June. Bell or Bullnose. Long Red Cayenne. 35 cts. per dozen; $\$ 2.50$ per 100.

Ruharb Roots, Victoria. Strong roots. $15 \mathrm{cts}$, each; $\$ 1.50$ per dozen; $\$ 10.00$ per 100 .

Sea Kale Roots. For forcing; doz., \$2.00; $100, \$ 15.00$.

Sweet Potato Plants. Ready in May and June, 100,60 cts.; $1000, \$ 4.00$.

Tomato Plants. Ready in May and June. Acme, Dwarf Champion, Perfection, Ponderosa, Stone, etc. Dozen, 30 cts.; 100, $\$ 2.00$. small Fruit varieties, dozen, $50 \mathrm{cts}$.

Pot grown plants, dozen, 40 cents.

\section{PLANTS OF HERBS.}

To meet the increasing demand for plants of the most popular herbs, we can supply the following:

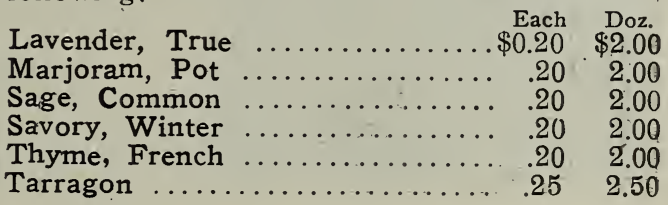

\section{FROST-PROOF CABBAGE PLANTS}

There are a number of sea islands along the South Carolina sea coast where the soil and climate conditions are just suited for growing tough, hardy cabbage plants during the Winter and early Spring. The plants make a slow but steady growth, until at eight to ten weeks of age they are very tough and hardy, the buds are purple and the outer leaves a reddish brown. When in this condition they can be shipped to territory further north and planted in the open ground a month to six weeks sooner than the home-grown hot bed or cold frame plants could be planted. These FROST PROOF CABBAGE PLANTS will stand a temperature of 8 to 10 degrees above zero without injury, the land freezing, or the plants being covered with ice, sleet or snow after they are planted will not injure them.

The plants grow very fast, maturing headed cabbage ten days to three weeks sooner than you can mature them from hot bed and cold frame plants.

TO GET THE ADVANTAGE OF THESE FROST PROOF CABBAGE PLANTS THEY MUST BE PLANTED A MONTH OR SIX WEEKS EARLIER THAN YOU WOULD PLANT HOME-GROWN PLANTS.

Our cabbage plants are shipped direct from our growing station in South Carolina by mail or express. We can fill orders from December to April fifteerith. We guarantee good delivery.

The plants will be somewhat wilted and have a hard, stunted appearance, which will be disappointing to persons who have never used these plants before. Regardless of appearance, they will produce the crop results.

Varieties, Early Jersey Wakefield, Charleston Wakefield, Succession and Early Flat Dutch.

Prices by mail postage paid, 50 cents per 100 . By express. buyer paying express charges, which under special rates are very low. 500 for $\$ 1.00$. In lots of 1,000 to 4,000 at $\$ 1.50$ per 1,000

Plants packed $500,1,000$ or 2,000 to the crat?. Order in these quantities, they weigh about 25 pounds per 1,000 plants crated for shipment. and can be shipped to any point where they will arrive within four or five days. No plants shipped C. O. D.

\section{SPE C I A L N T I C E.}

We have to depend upon European countries for many varieties of Seeds for our supplies and owing to war conditions profibiting imports we reserve the right to change prices and substitute varieties if we are unable to supply kinds ordered.

W. E. MARSHALL \& CO. 


\section{FARM AND FIELD SEEDS \\ FIELD CORN.}

Eight quarts will plant one acre in hills; three bushels will sow one acre broadcast.

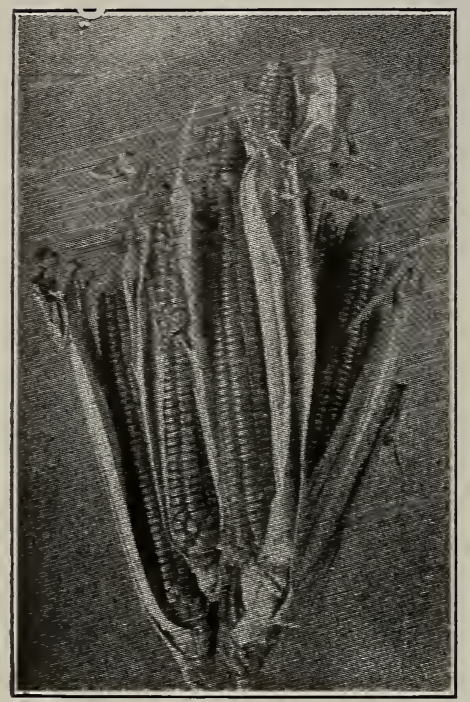

Longfellow Corn.

\section{FLINT VARIETIES.}

Early Yellow Canada. A very desirable variety. Ears rather small, 8-rowed and deep grained. The earliest Flint Corn, usually ripening in August and producing a large yield.........\$0.60

Longfellow. A very large-eared flint variety, grown very extensively in this vicinity for its productiveness. Ears, 8-rowed, often 14 to 15 inches long, with small cob and deep kennels

Sanford White Flint. Of spreading habit...... .75

\section{DENT VARIETIES.}

Improved Leaming. Large, handsome ears, deepgrained and of a deep orange color. An earlymaturing variety distinctly dent, and a great

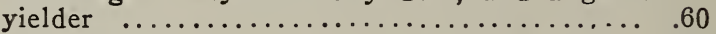

Pride of the North. (Dent.) Very large ears.. .60

FODDER AND ENSILAGE VARIETIES.

Early Golden Surprise. This is a cross between the Eureka and a Dent. The cob is small with very long grain, maturing very early and adapted for Northern climate. A very heavy

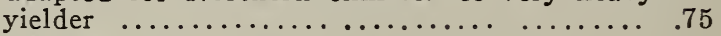

Eureka. A superior dent variety for ensilage, growing to a height of 12 to 15

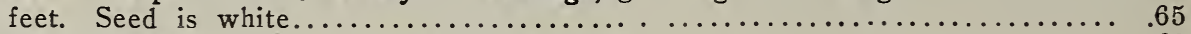

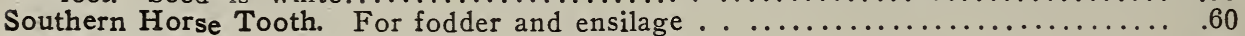

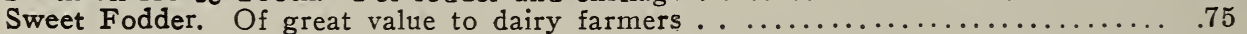

\section{BARLEY.}

48 pounds to the bushel. 2 bushels to the acre.

Spring Barley. A good standard sort................................. 75

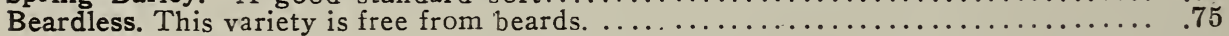

\section{BEANS.}

Sow $1 / 2$ to $3 / 4$ bushel to the acre.

Soja Bean. Hollybrook Early. Valuable as a forage crop and for fertilizing the soil. Thrives well in hot and dry weather. Sow broadcast one-half bushel to acre, or plant in drills three feet apart and one foot between plants......... 1.00

Velvet Bean. Used as a forage plant, and as a fertilizing plant for turning under Stock readily eat the vines and leaves. Plant in rows 4 feet apart and 1 foot

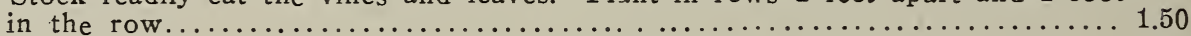

\section{BROOM CORN.}

Evergreen. Succeeds in a good deep soil; it is very sensitive to cold. 12 qts. to acre

BUCKWHEAT.

48 pounds to the bushel. 1 bushel to the acre.

Japanese. Earliest and most productive of the Buckwheats $\ldots \ldots \ldots \ldots \ldots \ldots \ldots . \$ \ldots 0.60$

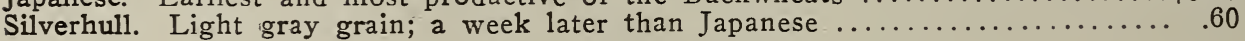

\section{MILLET.}

Golden (German Millet). Very large crop, thoigh not so early as Hungarian. Grow 3 to 5 feet high. Requires good soil.

Sow one bushel to the acre

Per Lb. Bush.

100 Lbs.

Hungarian. Sow from June to August 1 , at the rate of one bushel per acre $\quad .10 \quad 3.00 \quad 5.00$ Japanese (Barnyard Grass). 35 lbs. to the bus. Sow from May to Aug. $1.12 \quad \begin{array}{llll}12 & 3.00 & 8.00\end{array}$

Prices on all Farm Seeds are su'ject to Market fluctuations. 


\section{O A T S .}

Sow 2 to 3 bushels to the acre. 32 pounds to the bushel.

Storm King. The heads measure from 8 to 10 inches and the kernels are of immense size, thick, plump and heavy. It is very early, has great length or straw, producing 70 bushels per acre. We can safely say it is the greatest producer of any variety of Oats grown in this country. Per bus., $\$ 2.00 ; 10$ bus. lots, $\$ 1.85$ per bus.

White Tartar. A remarkably handsome and perfect white oat, extremely early, in fact, the earliest variety in cultivation. It is an enormous cropper. The straw is long, very strong, and holds up well. The heads are large and well filled. Peck, 50 cents; bus., $\$ 1.75 ; 10$ bus. or over, $\$ 1.60$ per bus.

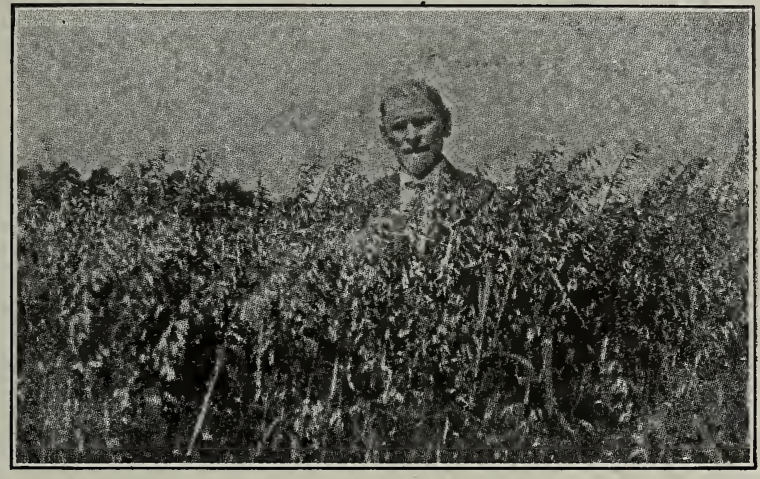

Field of Storm King Oats.

Regenerated Swedish Select. Popular for its heavy yields and specially adapted for light 1. soils. Very strong straw and branching habit. Per bus., $\$ 2.25 ; 10$ bus. lots, $\$ 2.00$ per bus.

Northern Grown' American. Very heavy. Per bushel\$1.50. 10 bushels, $\$ 1.40$ per bushel.

\section{P E A S .}

Canada Field. Valuable for cattle feeding. Also used for ensilage. Sown broadcast in the spring at the rate of two bushels to the acre. Market price.

Cow Peas, Clay. This variety is of extra strong growth and specially adapted for sowing in Northern States. Market price.

Cow Peas, Whippoorwill. A very early maturing variety of upright or bush growth. Market price.

\section{R A P E .}

Sow 10 pounds per acre broadcast, or 5 pounds in drills.

Dwarf Essex. Especially valuable for sheep pasturage. Market price.

R Y E .

Spring. Best Northern grown. One and one-half bushel to the acre......... Bushel, $\$ 1.75$ Giant Winter. Our own growing. Sow in September and October ................

\section{S O R G H UM.}

Early Amber Sugar-Cane. The earliest and mo $t$ productive variety. Height, 10 to 12 feet. For ensilage or fodder it posse ses good qualities; stock of all kinds relish it. Sow 7 pounds in drills, o - 15 pounds broadcast, to acre ... $\$ 0.15 \quad \$ 12.00$

Kaffir Corn (Red). Excellent forage for horse; and cattle, and excellent feed for poultry. Sow 4 to 5 pounds per acre $\ldots \ldots \ldots \ldots \ldots \ldots \ldots \ldots \ldots \ldots \ldots \ldots \ldots \ldots \ldots \ldots \ldots \ldots . .15$

\section{S U N F L O W E R.}

Mammoth Russian. Five pounds will plant on : acre...Lb., 10 cts.; 25 lbs., $\$ 2.00 ; 100$ lbs., $\$ 8.00$

\section{E T C H E S.}

Spring Tares (Vicia sativa). Sown broadcast at the rate of 60 to 100 pounds to the acre, like wheat or barley and sometimes mixed with oats for soiling. Market price.

Sand, Winter, or Hairy Vetch (Vicia villosa). Sow from 30 to $50 \mathrm{lbs}$. to the acre. Market price.

\section{W H E A T .}

The seed Wheat we offer is grown in Pennsylvania by a very reliable grower especially for seed purposes. Sow $11 / 2$ bushels to the acre.

Four Rowed Fulz. Red; hardy and very prolific, beardless................. Bushel, $\$ 2.50$

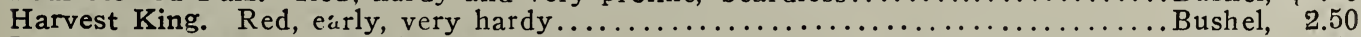

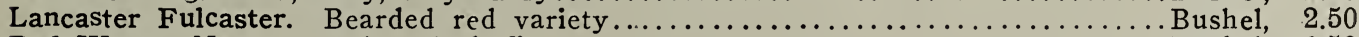

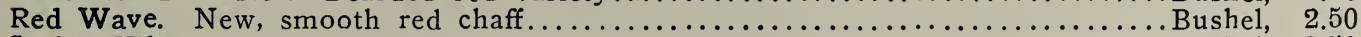

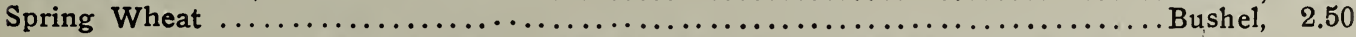




\section{MARSHALL'S LAWN GRASS SEEDS}

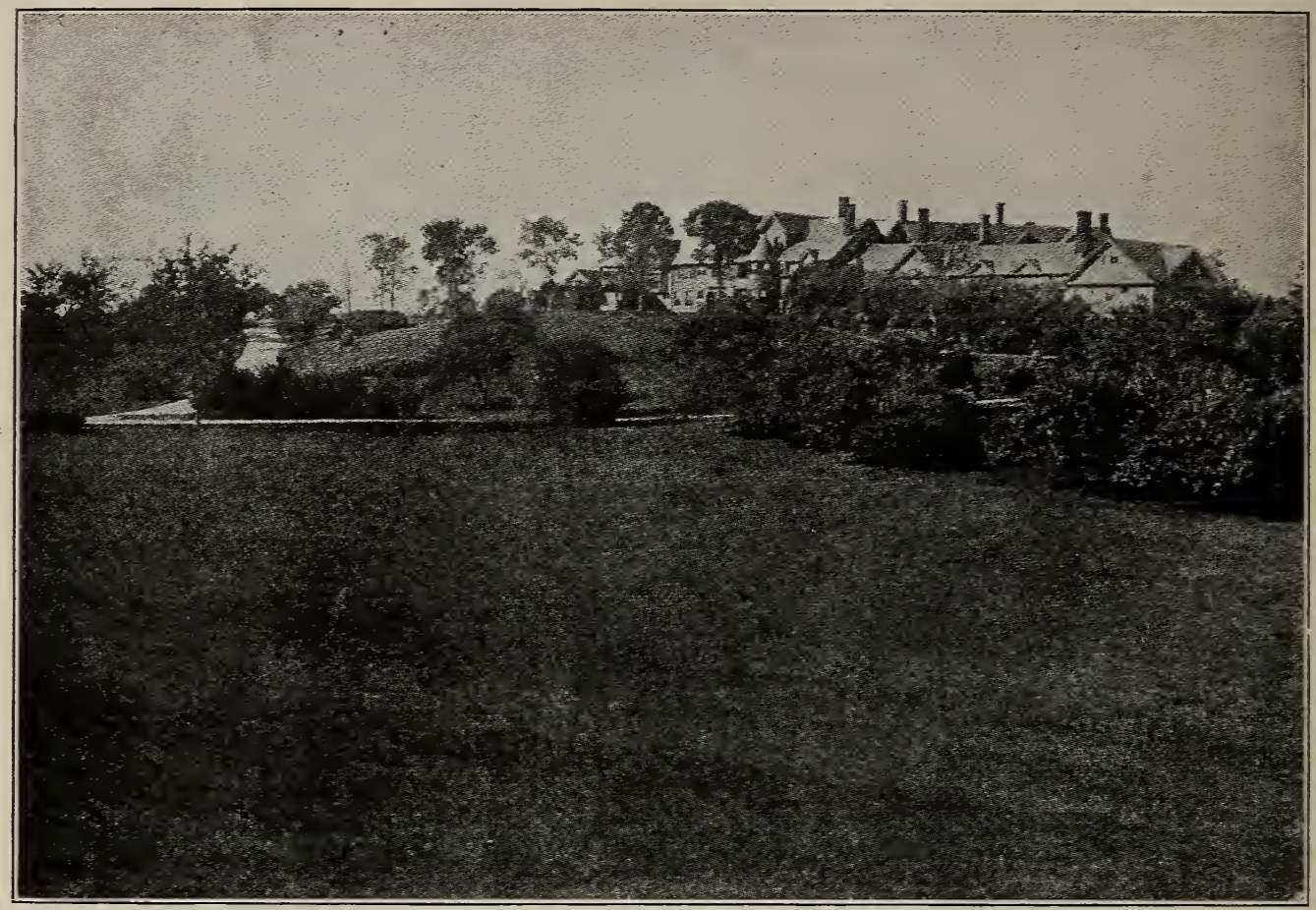

\section{MARSHALL'S SPECIAL LAWN GRASS MIXTURE.}

Marshall's Special Lawn Grass Seed produces a perfect and enduring lawn of luxuriant richness, with closely interwoven, firm and elastic turf, and it is usually ready for cutting in six weeks from time of sowing. This Lawn Grass is composed of a combination of various fineleaved, deep-rooting grasses of interweaving ha'jit, that flourish under our varied conditions, soils and climates, growing during different seasons of the year, so that a deep green, smooth and velvety sward, free from clumps, is maintained without burning brown in Summer.

This mixture includes highest grade recleaned seeds of Crested Dogstail, Creeping Bent, Rhode Island Bent, and other fine Grasses with White Clover.

Price: Per 1b., 40 cts.; 5 lbs., $\$ 1.75$; bus., 20 lbs., $\$ 6.50$; 25 lbs., $\$ \$ .00 ; 100$ lbs., $\approx 30.00$.

\section{MARSHALL'S CENTRAL PARK LAWN GRASS.}

Marshall's Central Park Lawn Grass will produce an even, dense growth of permanent sward as early in the season as it is possible to do. This mixture contains no annual grasses for making quick show to the detriment of a good lawn, but only those of lasting value and hardiness, which, when once established, need no reseeding for years. Uur seed, which we know to be as pure as can be found anywheree, is of the best varieties, best suited for even and permanent growth; it is carefully cleaned and free as it is possible to make it from foreign matter.

One quart will sow 15 x 20 feet (300 square feet); one peck, $50 \times 50$ feet ( 2500 square

feet); one bushel, $100 \times 100$ feet (10,000 square feet); four bushels one acre.

Price: Per pint, 15 cts.; quart, 25 cts.; 4 quarts, 75 cts.; peck, $\$ 1.25$; bushel (20 pounds), $\$ 4.50$.

\section{MARSHALL'S SHADY PLACE LAWN GRASS.}

Usually it is quite difficulty to obtain a satisfactory growth of grass under trees and in shady places; for sowing in such places we recommend the use of this special mixture. It will quickly produce an abundant and even growth of beautiful green grass. The grasses used in making this special mixture are only those adapted for growing in shade. It has been successfully used on some large operations where a green sward was desired on land partially shaded by old trees.

Price: Per quart, 30 cts.; 4 quarts, $\$ 1.00$; peck (5 pounds), $\$ 1.60$; bushel (20 pounds), $\$ 6.00$. 


\section{MARSHALL'S TERRACE MIXTURE LAWN GRASS.}

A special mixture of grasses for sowing on terraces and side hills-grasses that produce strong spreading roots, thus preventing heavy rain from washing them out; that will withstand drought and exposure, thrive on shallow soils, and produce a rich, green turf throughout the season.

Price, per quart, 30 cents; Per peck, $\$ 1.75$; per bushel (20 pounds). $\$ 6.00$.

\section{MARSHALL'S LAWN RESTORING GRASS SEED.}

A mixture of grasses suited to take firm hold and grow quickly on hard, worn out, or burned spots. The best time to resow them is very early in spring, but seed may also be sown from September to October.

Per quart, 25 cents; per peck, $\$ 1.25$; per bushel (20 pounds), $\$ 5.00$.

\section{SPECIAL LAWN GRASS MIXTURE FOR SEA-SIDE LAWNS.}

A mixture of fine grasses peculiarly suited to seaside lawns and very sandy soils.

Per quart, 30 cts.; per peck, $\$ 1.50$; per bushel (20 pounds), $\$ 5.00$.

\section{MARSHALL'S SPECIAL MIXTURE.}

FOR TENNIS COURTS, CROQUET GROUNDS, BOWLING GREENS, ETC.

A mixture of grasses that will form a good turf adapted for out-door games, containirg fine leaved, deep rooting grasses that spread and maintain a tough evergreen sward and improve by stamping. The seed should be sown thickly to obtain quick results.

Price, per quart, 30 cts.; 4 quarts, $\$ 1.00$; peck, $\$ 1.75$; bushel (20 pounds), $\$ 6.00$.

\section{PERMANENT GRASS MIXTURES FOR GOLF LINKS.}

\section{MARSHALL'S FAIR GREEN MIXTURE.}

This is composed mainly of perennial rative grasses and two very important European grasses which have proven of great value for Fair-Green use. They are all of dwarf spreading growth, forming a close velvety surface which improves from year to year if given proper care.

Per bushel (20 pounds), $\$ 4.00$.

\section{MARSHALL'S PUTTING-GREEN MIXTURE.}

The hardiest and finest low growing Grasses are contaired in this Mixture. It produces a beautiful and lasting green turf calculated to withstand hard wear and tear. Per peck, $\$ 2.00$; per bushel (20, pounds), $\$ 7.00$.

\section{GRASSES FOR PERMANENT HAY CROPS AND PASTURES.}

The result obtained from our special Grass Seed mixtures are well known by the constantly increasing demand for them. Fall seeding is prefrable, but spring sowing will be successful if done early, while the land is cool and moist. In addition to the Grasses, we advise sowing 5 pounds of Mixed-Clover Seed per acre.

\section{MIXTURES FOR HAY \& PERMANENT PASTURES FOR ONE ACRE.}

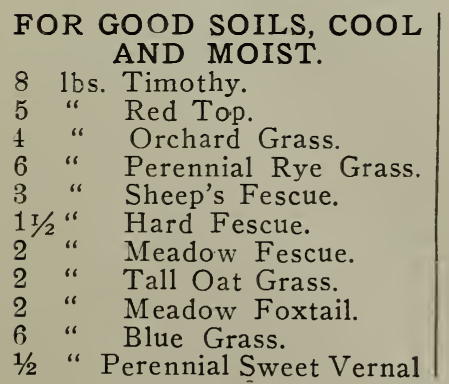

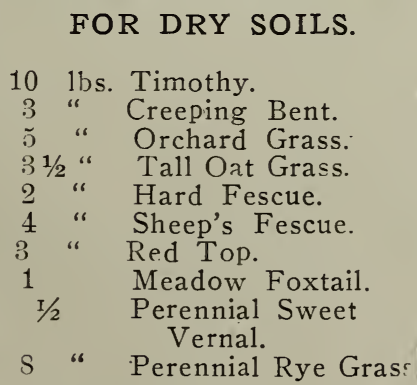

FOR WET SOILS.

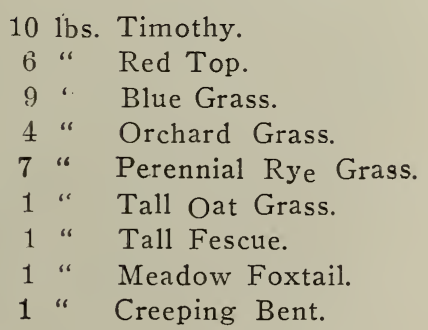

Per Bushel (15 pounds), \$3.00. Per acre (40 pounds), $\$ 8.00$. Per 100 lbs., $\$ 19.00$. Mixed Clover Seed: Per lb.,35 cts.; 10 lbs., $\$ 3.00 ; 100$ lbs., $\$ 30.00$. 


\section{GRASSES AND CLOVERS}

Prices subject to market changes.

Bromegrass. (Bromus inermis.) Valuable fo: dry, arid soils..... Canada Blue Grass. (Poa Compressa). Usisul for sowing on hard

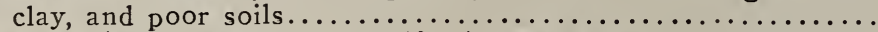

Creeping Bent (Agrostis stolonifera). Desirable for mixing with

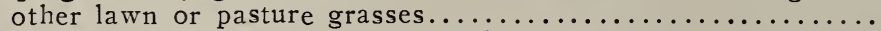

Crested Dogstail (Cynosurus Cristatus). Valuable for pastures and

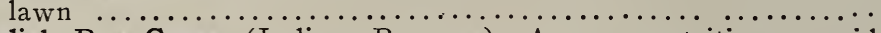

English Rye Grass (Lolium Perenne). A very nutritious, rapid growing variety; valuable for meadows and pastures.........

English Rye Grass (Pacey's). A carefully selected short-seeded,

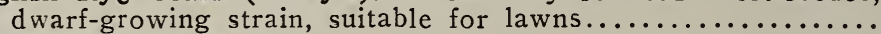

Fine Leaved Fescue (Festuca Ovina Tenuifolia). Suitable for lawns

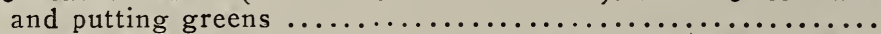

Hard Fescue (Festuca duriuscula). A dwarf-growing grass.

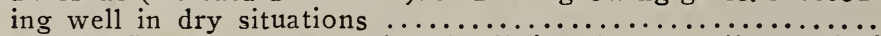

Italian Rye Grass (Lolium Italicum). Thrives in any soil and yield

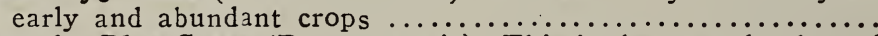

Kentucky Blue Grass (Poa pratensis). This is the most hardy and

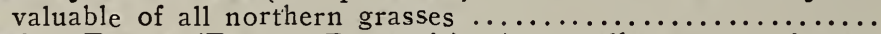

Meadow Fescue (Festuca Pratensis). An excellent grass of great

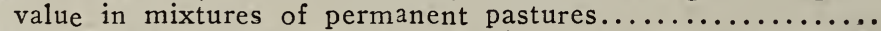

Meadow Foxtail (Alopecurus Pratensis). One of the earliest and

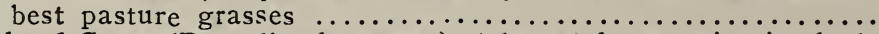

Orchard Grass (Dactylis glomerata). Adapted for growing in shady

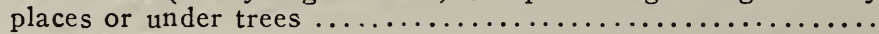

Red Fescue (Festuca Rubra). Valuable for lawns and sandy soils

Red Top (Agrostis vulgaris). A permanent grass, standing our

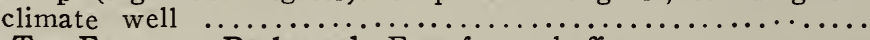

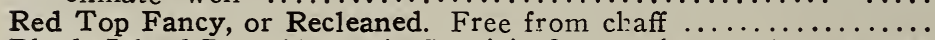

Rhode Island Bent (Agrostis Cannia). One of the very best grasses

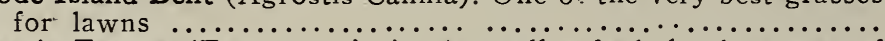

Sheep's Fescue (Festuca ovina). A small tufted, hardy grass, of

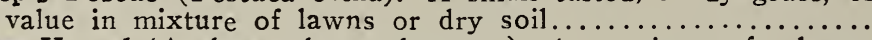

Sweet Vernal (Anthoxanthum odoratum). As a mixture for lawns

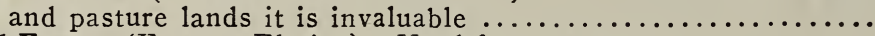

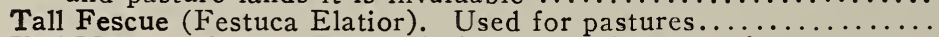

Tall Meadow Oat (Avena elatior). A valuable grass for permanant

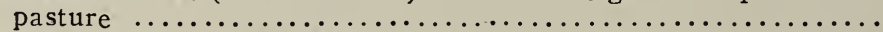

Timothy (Phleum pratense). A field and not a pasture grass, as will not endure close and frequent cropping. Market price...

Wood Meadow (Poa memoralis). Adapted for shaded positions in

lawns or under trees ..............................................

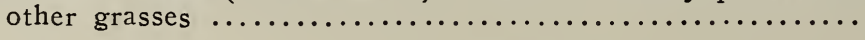

\section{L O V E R S .}

Prices subject to market changes.

Alfalfa, or Lucerne (Meddicago Sativa). One of the most valuable

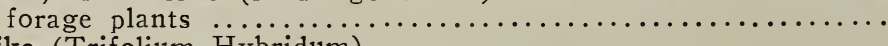

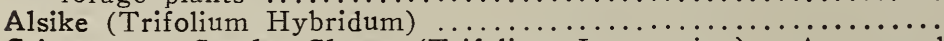

Crimson, or Scarlet Clover (Trifolium Incarnation). An annual

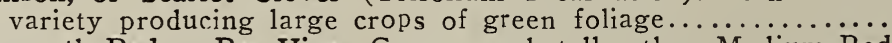

Mammoth Red or Pea Vine. Grows much taller than Medium Red

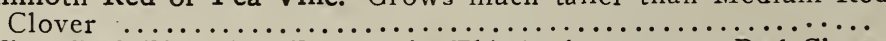

Medium Red (Trifolium Pratense). This is the common Red Ciover

so largely grown throughout the country........................
Sweet Clover, Bokhara (Melilotus alba). Grows from 3 to 4 feet

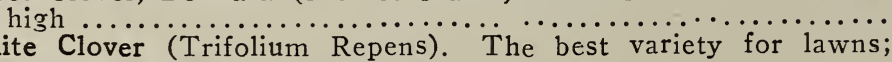
White Clover (Trifolium Repens). The best variety for lawns;
valuable in permanent pastures $\ldots \ldots \ldots \ldots \ldots \ldots \ldots \ldots \ldots \ldots \ldots \ldots \ldots$

Mixed Clover

ght per

$1 \pm \$ 0.50$

$14 \quad .20$

Bushel 100 Lbs.

$\$ \pm .50 \quad \$ \pm 5.00$

14.60

20 . .35

2.50

10.00

24.15

7.00

50.00

24

24

6.50

32.00

.15

2.50

10.00

$16 \quad .60$

2.75

11.00

14

.40

9.00

50.00

18

.15

4.50

30.00

14

.25

2.25

12.00

14

.25

3.00

20.00

10

.60

3.25

23.00

14

.30

5.50

50.00

14

.35

3.50

25.00

14

.20

4.25

30.00

32

2.50

16.00

$.30 \quad 9.00$

26.00

14.60

7.00

50.00

$14 \quad .35$

4.25

30.00

$10 \quad .50$

4.00

$22 \quad .40$

8.00

$\dddot{35.00}$

$10 \quad .30$

2.75

26.00

45

.15

5.50

12.00

14

.60

6.25

50.00

12

.20

2.00

15.00
Quantity for acre

$\mathrm{Pe}$

20 lbs. $\$ 0.30 \$ 15.00 \$ 25.0$ !) 15 lbs. $\quad .35 \quad 18.00 \quad 30.00$

20 lbs. $\quad .25 \quad 12.00 \quad 20.00$

10 lbs. $\quad .35 \quad 18.00 \quad 30.00$

15 lbs. $\quad .35 \quad 18.00 \quad 30.00$

$\begin{array}{llll}15 \text { lbs. } \quad .35 & 19.20 & 32.00\end{array}$

$\begin{array}{lllll}10 & \text { lbs. } \quad .75 & 42.00 & 70.00\end{array}$ $\begin{array}{llll}10 \mathrm{lbs} . & .35 & 18.00 & 30.00\end{array}$ 


\section{GENERAL LIST OF . Marshall's Select Flower Seeds}

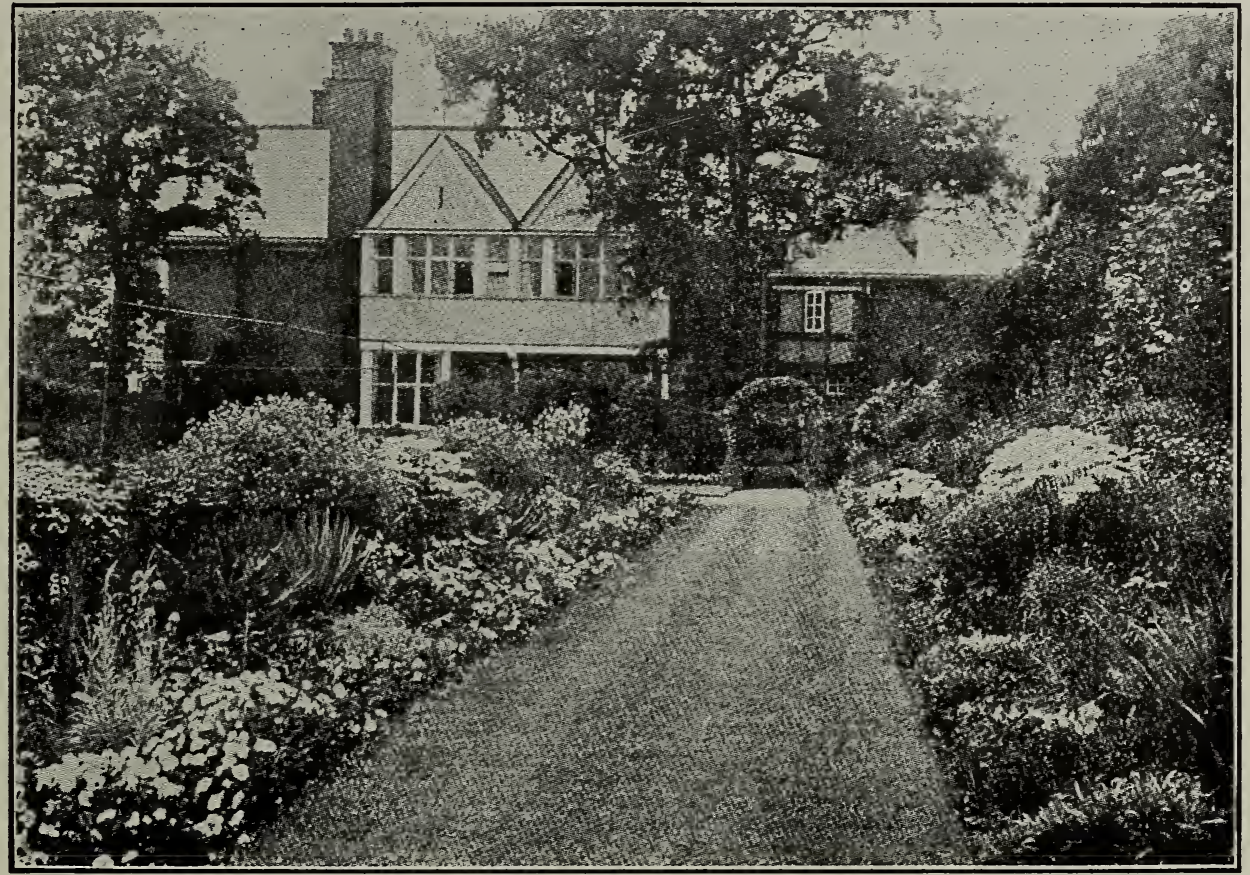

Border of Annuals and Biennials with Grass Walk.

\section{ALL FLOWER SEEDS ARE MAILED FREE AT PACKET, OUNCE AND POUND RATE TO ANY POST OFFICE IN THE UNITED STATES.}

The following list contains a most complete assortment of the choicest and most popular flowers for either conservatory, greenhouse or girden culture:

Annuals grow from seed, flower, mature their seed, and die in one year, or, in other words, the same season.

Hardy Annuals are those which can be sown in the open ground.

Half-Hardy Annuals are those which shou'd be started early in the house, conservatory or hotbed, and transplanted to the garden in settled warm weather.

Biennials grow from seed, sown from June to August, flower, ripen their seed and die the next year, though some varieties bloom the same season if sown early in gentle heat.

Hardy Biennials w:ll winter in the open ground without protection.

Perennials grow frcm seed, and continue flovering annually for many years after the first season. Some varieties flower the first seaso 1 if planted early in gentle heat.

Half-Hardy Biennials require the protection of a cold frame or cnol house during winter.

Hardy Perennials can remain in the open ground during winter without protection. winter.

Half-Hardy Perennials require the protection of a cold frame or cool house during the

Tender or Greenhouse Perennials require window or greenhouse culture, free from frost during winter, and thrive in the garden during the warm months.

\section{EXPLANATION OF FLOWER SEED ABBREVIATIONS.}
H. A. designates Hardy
Annuals-Lasting but one Half-Hardy Annuals-Lasting but
H. H. A. " Half-Hardy
H. P. designates Hardy Perenniels-Lasting three or
H. B.
Harrly Bienniels-Lasting but years.
H. H. B. “ Half-Ilardy Biennials-Require
H. H. P. " more years.
Half-Hardy Perennials-Require
protection during winter.
H. C. " Harry Climber-Lasting three or
G. S. " " Greenhouse Shrub. protection during winter. $\quad$ H. A. C. “ Annual Climber. 
ABOBRA Viridiflora. $A^{\bullet}$ rapid-growing, climbing plant, scarlet fruit.. ABRONIA, Umbellata. Training annual, pink flower trusses........

ABUTILON. New hybrid's, mixed, large bell-shaped flowers......... ACACIA. Finest mixed, elegant winter and spring flowering plants.. ACHILLEA Ptarmica, The Pearl. Double white flowers.......... 1 $1 / 2$

ACONITUM (Monk's Hood). 'With showy spikes of hood-shaped blossoms.

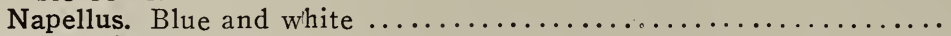

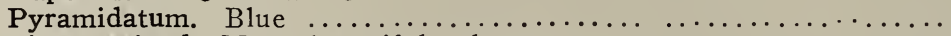

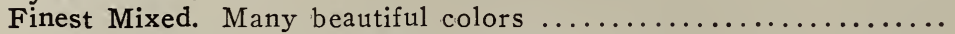

ACROCLINIUM. Pretty everlasting flowers; fine for winter bouquets

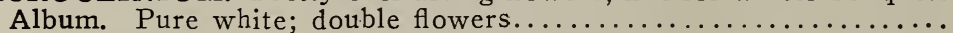

Roseum. Bright rose; double flowers...................

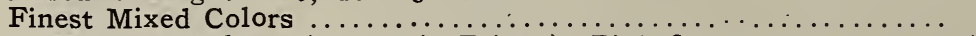

ADLUMIA. Cirrhosa (Mountain Fringe). Pink flowers........... 10

ADONIS Aestivalis. Crimson flowers and feathery foliage......... 1

Autumnalis. Flowers crimson with dark center............... 1

Vernalis. Large, yellow; lowers in early spring ................ $11 / 2$

AGERATUM. Blooms throughout the summer; feathery flowers in clusters.

Mexicanum. Fine for bedding or pot culture. Blue ........... 11/2

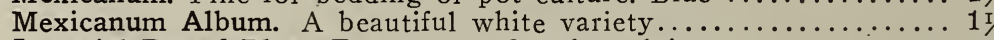

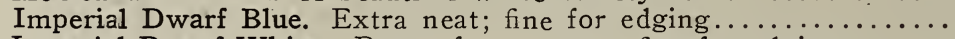

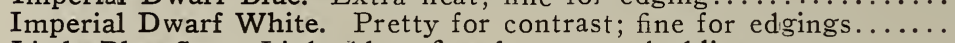

Little Blue Star. Light 'blue; fine for carpet bedding.............

Princess Victoria Louise. Dwarf, light blue, white center.........

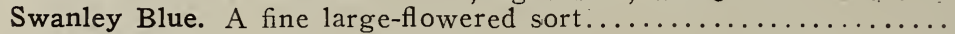

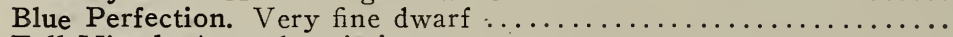

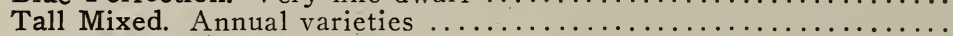

AGROSTEMMA Coeli Rosa (Rose of Heaven). Bright rose; excel-

lent for cutting $\ldots \ldots \ldots \ldots \ldots \ldots \ldots \ldots \ldots \ldots \ldots \ldots \ldots \ldots \ldots \ldots \ldots \ldots \ldots \ldots \ldots \ldots \ldots \ldots \ldots \ldots \ldots \ldots \ldots \ldots \ldots \ldots \ldots \ldots \ldots$
Coeli Alba. White $\ldots \ldots \ldots \ldots \ldots \ldots \ldots \ldots$

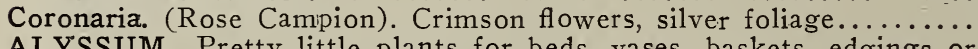

ALYSSUM. Pretty little plants for beds, vases, baskets, edgings or rockwork; blooming profusely all summer.

Maritimum (Sweet Alyssum). Fragrant, white; flowers all summer

Maritimum compactum, Little Gem. Grows erect; fine for edging...

Bethamii compactum. Lilac Queen. Pure lilac flowers, dwarf and

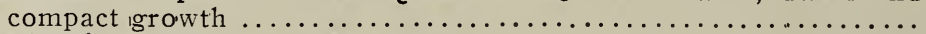

Bethamii compactum lutescens. Yellowish flowers on strictly up-

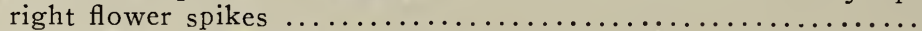

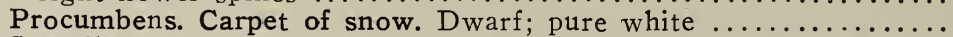

Saxatile compacta. Spring-blooming Alyssum with yellow flowers...

AMARANTHUS. Ornamental foliage plants, producing a striking effect either in the conservatory or flower garden.

Caudatus (Love Lies Bleeding). Long drooping crimson spikes...

Tricolor (Joseph's Coat). Leaves red, yellow and green..........

Salicifolius (Fountain Plant). Distinct variety, with graceful droop-

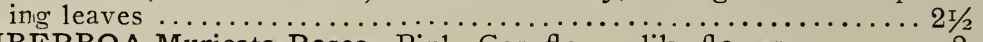

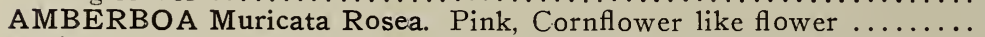

AMPELOPSIS Veitchii (Japanese Woodbine or Boston Ivy).......

ANAGALLIS Grandiflora (Pimpernelle). Showy garden plant......

ANCHUSA Capensis. Flowers resem'bling large Forget $\mathrm{Me}$ Nots... 11/2

Grandiflora. Dropmore. Large flowered, dark blue............ 5

ANEMONE. A very pleasing perennial, producing large flowers.

Cororaria (Poppy Anemone). Mixed colors................. 1

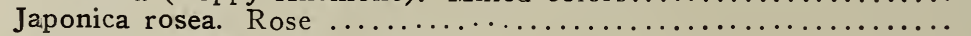

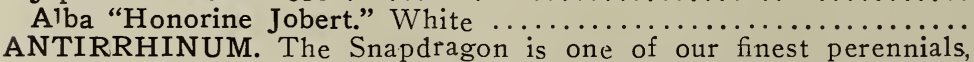
flowering the first year as annuals. Their rich spikes are beautiful for cutting, and keep fresh a long time. From seed sown in the open ground plants will bloom in July and August.

Large Flowering Half-Dwarf Varieties. The best for bedding purposes. growing about 18 inches high.

Dwarf Black Prince. Dark leaved, blackish crimson purple.......

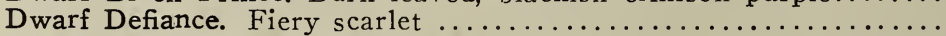

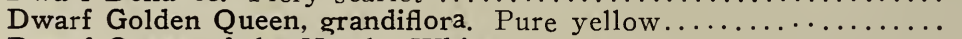

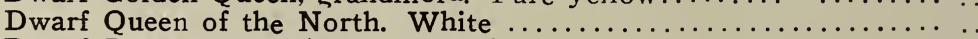

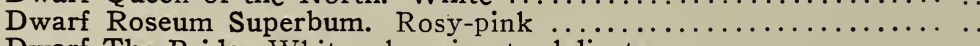

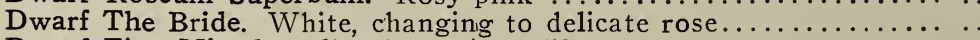

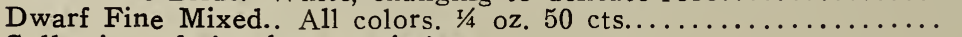

Collection of six above varieties
$10 \mathrm{H}$

Duration Ounce Pkt.

$\begin{array}{lr}\text { H.H.C. } \$ 0.00 & \$ 0.05 \\ & .05\end{array}$

G.S. $\quad . . \quad .10$

G.S. $\quad .50 \quad .05$

H.P. ... .10

4 H.P. ... .10

4 H.P. $\quad$.. $\quad .10$

H.P. ... .Uธ์

H.H.A. ... .0

$\begin{array}{lll}\ldots \ldots & .05 \\ \ldots & .05\end{array}$

$\begin{array}{lll}\cdots & \cdots & .05\end{array}$

H.A. $\quad .25 \quad .05$

H.A. $.25 \quad .05$

H.P. . .

H.A. $\quad .50 \quad .05$

$\begin{array}{lll}\ldots \ldots & .50 \quad .05\end{array}$

$\begin{array}{llll}3 / 4 & \ldots \ldots & .50 & .050\end{array}$

$3 / 4 \quad \ldots \ldots . \quad .50 \quad .05$

$\begin{array}{llll}1 / 2 & \ldots \ldots & \ldots & .10\end{array}$

$3 / 4 \quad \ldots \ldots \ldots \quad \ldots .10$

$1 \ldots \ldots . \quad .50 \quad .10$

$3 / 4 \ldots \ldots . \quad .75 \quad .10$

$1 \ldots \ldots . \quad .30 \quad .05$

$1 / 2 \quad$ H.A. $.40 \quad .05$

$\begin{array}{lll}\text { H.A. } & .40 & .05 \\ \ldots \ldots & .40 & .05\end{array}$

H.P. $\quad .40 \quad .05$

I/2 H.A. . 30 .U5

$1 / 2 \ldots \ldots . \quad .50 \quad .05$

$1 \mathrm{r} / 2 \ldots \ldots . \quad \ldots \quad .10$

$1 / 2 \ldots \ldots .10$

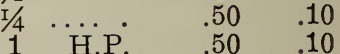

3 H.H.A. $.25 \quad .05$

$2 \ldots \ldots . \quad .25 \quad .05$

$\begin{array}{llll}1 / 2 & \ldots \ldots & .50 & .05\end{array}$

10 H.C. $\quad .50 \quad .10$

H.H.A. $.30 \quad .05$

H.A. $.50 \quad .05$

H.P. $\quad \ldots . \quad .10$

1 H.P. $\quad$.. 10

$\begin{array}{lll}\ldots \ldots & \ldots & .25 \\ \ldots \ldots & \ldots & .25\end{array}$

.... $\ldots .25$

H.H.B.

1 H.H.B. $\$ 1.50 \$ 1.10$

$\begin{array}{lr}\ldots \ldots & 1.50 \quad .10\end{array}$

$\ldots \ldots \quad 1.50 \quad .10$

$\ldots \ldots .10$

$\ldots \ldots . \quad 1.50 \quad .10$

$\begin{array}{lll}\ldots \ldots & 1.50 & .10 \\ \ldots \ldots & 1.00 & .10\end{array}$ 
ANTIRRHINIUM (Continued). Giant Flowering.

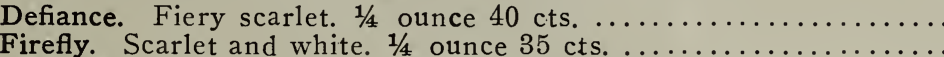

Nelrose. Rich coral-pink. A splendid forcer.

Queen Victoria. Large, white. $1 / 4$ ounce, 35 cts.

Roseum. Rose. $1 / 4$ ounce, 35 cts.

Romeo. Deep rose, shaded pink. $1 / 4$ ounce, $35 \mathrm{cts} . \ldots \ldots \ldots \ldots \ldots \ldots$

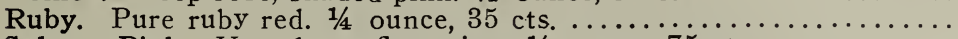

Salmon Pink. Very large flowering. $1 / 4$ ounce, 75 cts. ..........

Silver Pink. A large flowering variety.

Striped. Odd and pretty. $1 / 4$ ounce, $35 \mathrm{cts} . \ldots \ldots \ldots \ldots \ldots \ldots$

Venus. Delicate rose on white ground. $1 / 4$ ounce, $75 \mathrm{cts} . \ldots \ldots \ldots \ldots$

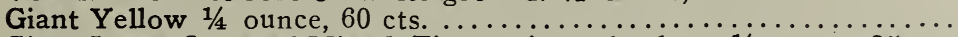

Giant Large-flowered Mixed. Fine variety of colors. $1 / 4$ ounce, $25 \mathrm{cts}$.

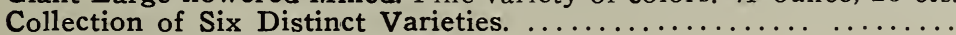

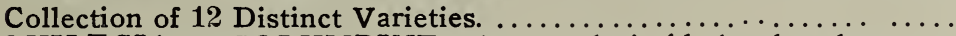

AQUILEGIA, or COLUMBINE. A most desirable border plant ....

Marshall's Matchless Long Spurred Hybrids. A grand variety of colors of the long spurred and large flowered forms. 1/16 ounce

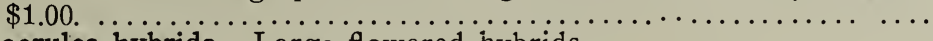

Coerulea hybrida. Large flowered hybrids. $\ldots \ldots \ldots \ldots \ldots \ldots \ldots \ldots$

Chrysantha. Long-spurred, golden yellow. $\ldots \ldots \ldots \ldots \ldots \ldots \ldots \ldots$

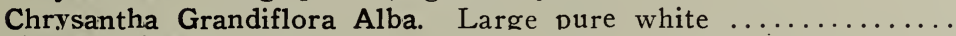

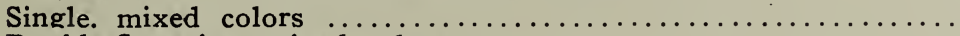

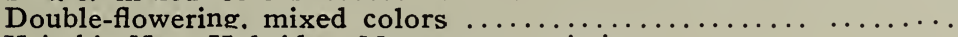

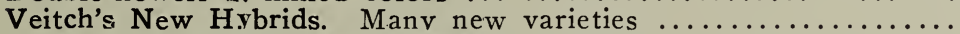

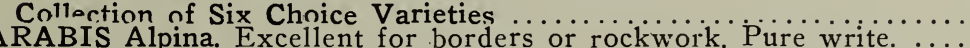

ARABIS Alpina. Excellent for borders or rockwork. Pure write. ...

ARCTOTIS grandis. Daisy-like flowers: white shaded yellow. .....

ARDISIA crenulata. Decorative plant: red berries $\ldots \ldots \ldots \ldots \ldots \ldots \ldots$
ASPERULA Odorata (Woodruff). Sweet-scented: white. $\ldots \ldots \ldots \ldots \ldots$

ASPARAGUS Plumosus Nanus. Graceful and featherv: bright green

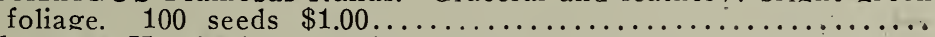

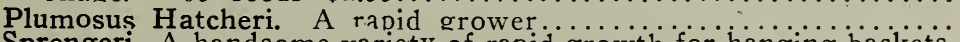

Sprengeri. A handsome variety of rapid growth for hanging baskets.

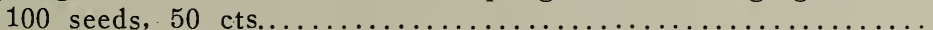

ASTERS. Plants from seeds sown in the open ground in Mav bloom finely in September and October, when the flowers are seen at their best. For Tulv and August flowers. sow in March or April. in cold frame, spent hot-bed, or pots or boxes in the house. Cover the seeds about half an inch deep with rich, light soil. and when the plants have three or four leaves transplant about 18 inches apart each way into well-prepared beds.

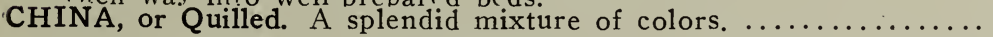

CHRYSANTHEMUM FLOWERED. Dwarf. A splendid variety of compact habit.

Separate colors. Brilliant Rose. Dark Blue. Fiery Scarlet. Light

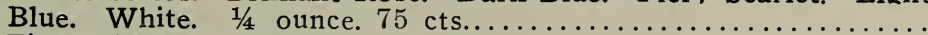

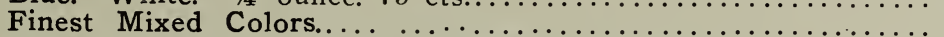
Collection of Six Distinct Varieties $\ldots \ldots \ldots \ldots \ldots$
Very early; on style of Queen of the Market, but with large flower

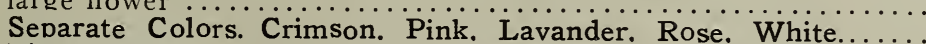
Finest Mixed. All colors

GIANT BRANCHING COMET. A Giant Comet type of Branching Asters. All large full flowers

Separate Colors. Crimson. Lavender. Light Pink. Roval Purple. Rose and White

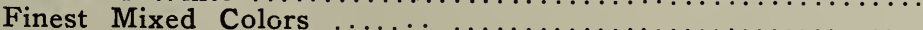

IMPROVED GIANT BRANCHING. The flowers are large and

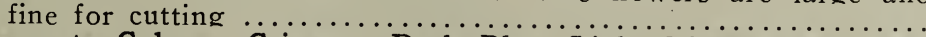

Separate Colors. Crimson. Dark Blue. Light Blue. Rose. ShellPink. White

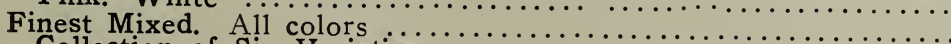

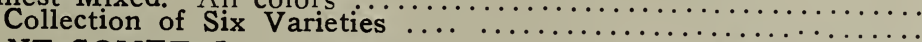

GIANT COMET. Long stemmed flowers like Japanese Chrysanthemums. Separate Colors. Crimson, Dark Blue, Light Blue, Rose, White

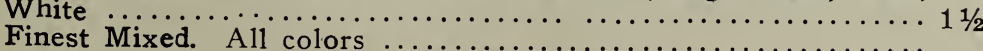

Collection of Six Distinct Varieties

$\begin{array}{ccc}\text { H. P. } & 1.00 & .10 \\ \text { H. A. } & 1.00 & .10 \\ \text { G. S. } & 1 . .9 & .25 \\ \text { H. P. } & 1.50 & .10\end{array}$

8 G. P. 
ASTERS. Continued. NAME AND DESCRIPTION.

Marshall's King. Upright growth; large flowers with long and

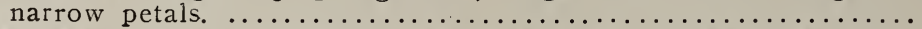

Separate Colors. Crimśon, Dark Blue, Light Blue, Rose. Pink

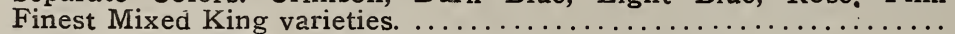
OSTRICH PLUIME. Splendid class; fine for cutting . ............ Separate Colors. Light Blue, Crimson, Rose and White ........ Finest Mixed Colors

QUEEN OF THE MARKET. The earliest of all; in full boom two

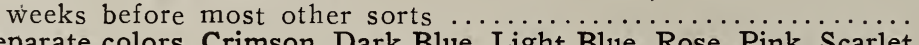
Separate colors. Crimson, Dark Blue, Light Blue, Rose, Pink, Scarlet

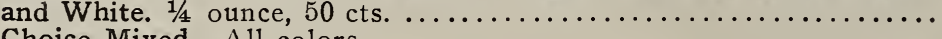

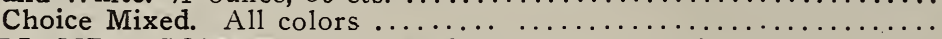

TRIUMPH COMET. A magnificent ciass of mid-season Asters. Extra long stems, full double flowers of the finest type $\ldots . . . . \%$

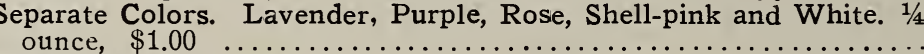
Finest Mixed Colors

DAYBREAK. A delicate pink Aster. The flowers are very double and globe-shaped. $1 / 4$ ounce, $\$ 1.00 \ldots \ldots \ldots \ldots \ldots \ldots \ldots \ldots \ldots$

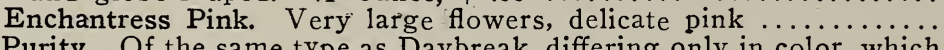

Purity. Of the same type as Daybreak, differing only in color, which

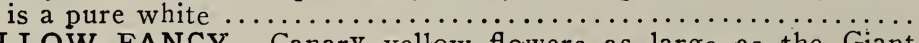

YELLOW FANCY. Canary yellow flowers as large as the Giant

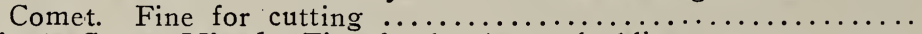

Single Comet Mixed. Fine for border or bedding. ..............
ASTER. Michaelmas Daisy. Large flowering hardy mixed fall flower-

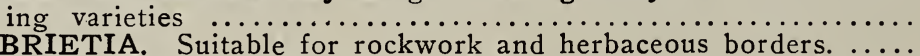

AUBRIETIA. Suitable for rockwork and herbaceous borders. $\ldots \ldots$
Graeca. Purple; trailing $\ldots \ldots \ldots \ldots \ldots \ldots \ldots \ldots \ldots \ldots \ldots \ldots \ldots \ldots \ldots \ldots \ldots \ldots \ldots \ldots$

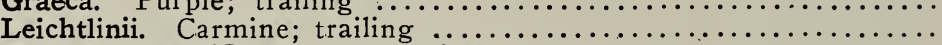

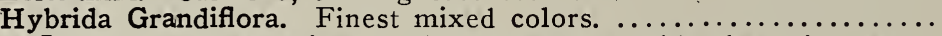

AURICULA. Finest Mixed. The flowers resemble the Primrose..

BACHELOR'S BUTTONS. (See Centaurea Cyanus).

BALLOON VINE. White flowers, followed by a balloon-like seed pods

BALSAM (Lady's Slipper). Showy and easily grown tender annuals, succeeding best in sunny situations where there is rich loam....
Double Separate Colors. White, lavender, blood-red, deep rose,

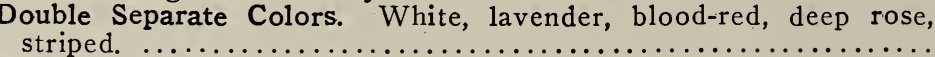

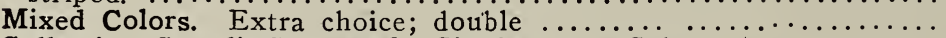

Collection Camelia-Flowered. Six Separate Colors ..............

BAPTISIA Australis. A large plant, with spikes of pea-shaped blue

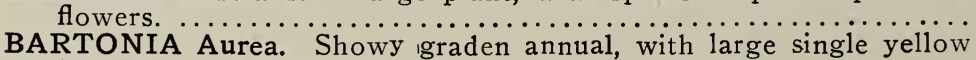

BEGONIA. Bedding Varieties. The following are of the Semperflorens type. Fine for bedding in full sun or shaded situations.

Erfordii. The best carmine bedding variety. $1 / 32$ oz. $\$ 2.00$. .....

Gracilis Rosea. Free-flowering, dclicate rose $\ldots \ldots \ldots \ldots \ldots \ldots \ldots$

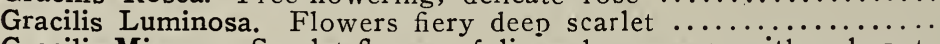

Gracilis Mignon. Scarlet flowers, foliage deep green, with red spots

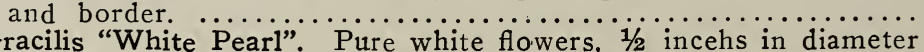

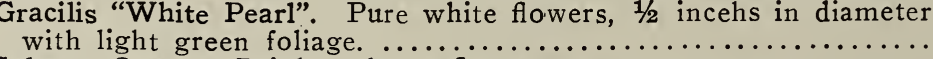

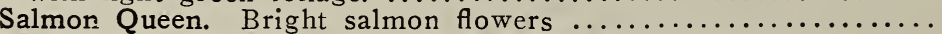

Vernon. Bronze foliage with scarlet flowers, $1 / 16$ oz. 50 cts. .....

BEGONIA. Tuberous-Rooted. Produce magnificent flowers; grown

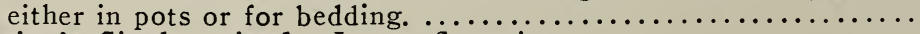

Laing's Single, mixed. Large flowering $\ldots \ldots \ldots \ldots \ldots \ldots \ldots \ldots$

Laing's Double, mixed. Large flowering ............................

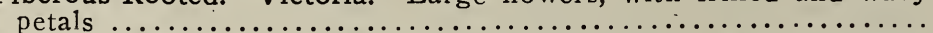

BELLIS perennis fl. pl. (Double English Daisy) Popular spring flowering perennial often used with Pansies and Forget-Me-Nots.

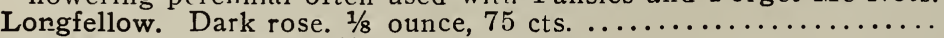

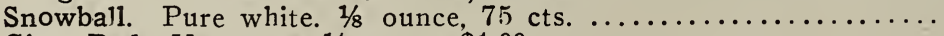

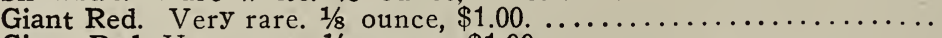

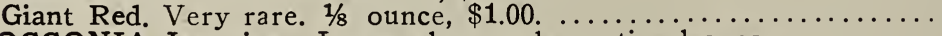

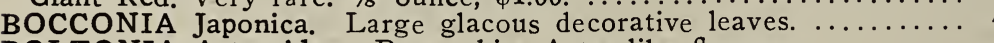

BOLTONIA Asteroides. Pure white Aster-like flowers. ......... 4

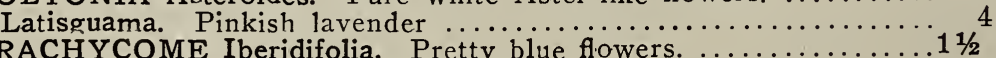

BRACHYCOME Iberidifolia. Pretty blue flowers. $\ldots \ldots \ldots \ldots \ldots \ldots \ldots \ldots \ldots$
Iberidifolia. Mixed. Swan River Daisy, for edging. $\ldots \ldots \ldots \ldots \ldots$

Height feet Duration Ounce Per

2 H A 300

2

$2.50 \quad .10$

$\$ 3.00 \quad 0.10$

$\ldots \ldots .2 .00 \quad .10$

$1 / 2$

. $\quad \therefore \ldots \therefore 1.50 \quad .12$

$\ldots \ldots 1.25 \quad .10$

2

$\begin{array}{llll}\ldots & \ldots \ldots \ldots & 3.50 & .10 \\ \ldots & \ldots \ldots & 3.00 & .10 \\ 2 & \ldots \ldots & 3.00 & .10 \\ 2 & \ldots \ldots & . . & .20 \\ & & & \\ \ldots & \ldots \ldots & 3.00 & .10 \\ 2 & \ldots \ldots & 3.00 & .10 \\ 2 & \ldots \ldots & 1.00 & .10\end{array}$

$21 / 2 \quad$ H. P. $\quad 2.00 \quad .10$

1 H. P. 10

$\begin{array}{lll}\ldots \ldots & . & .10 \\ \ldots \ldots & . & .25\end{array}$

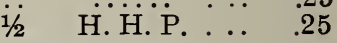

15 H. H. C. $.20 \quad .05$

H. A.

$\begin{array}{lrr}\ldots \ldots & .60 & .05 \\ \ldots \ldots & .50 & .05 \\ \ldots \ldots & . . & .40\end{array}$

$\begin{array}{llll}21 / 2 & \text { H. P. } & .60 & .10\end{array}$

1 H. A. $.40 \quad .05$

$1 / 2 \quad$ H. H. P. . . .25

$3 / 4 \quad \ldots \ldots \ldots \quad \ldots \quad .25$

.25

$1 / 2 \quad \ldots \ldots \ldots \quad \ldots \quad .25$

$3 / 4$

1 G.P

......

.50

1

H. P.

.... 4.00

.10

$\ldots \ldots 4.00 \quad .10$

..... $6.00 \quad .10$

$\ddot{H} \ddot{\mathrm{P}} 4.00 \quad .10$

$.30 \quad .05$

H. P. . . . 25

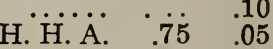

H. H. A. $.50 \quad .05$ 


\section{NAME AND DESCRIPTION.}

BROWALIA Elata coerulea. Bright blue, fine for cutting.

Roezli. Free-flowering, bluish-white $\ldots \ldots \ldots \ldots \ldots \ldots \ldots$

Speciosa major. Flowers $1 \frac{1 / 2}{2}$ to 2 inches across; blue, white throat.

BRYONOPSIS laciniosa. Pretty ornamental gourd. .............

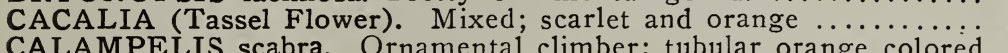

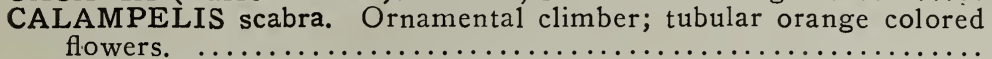

ALCEOLARIA HYBRIDA GRANDIFLORA. Highly prized plants

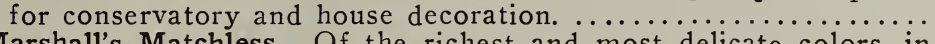

Marshall's Matchless. Of the richest and most delicate colors, in the most marvelous variety of shades and marking self spotted,

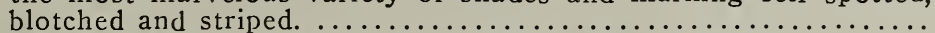

Large-Flowering, Dalkeith Park Strain. Finest varieties ........

Rugosa Yellow. The well known yellow bedding variety. ...........

CALENDULA. (Cape Marigold). Free and continuous flowering

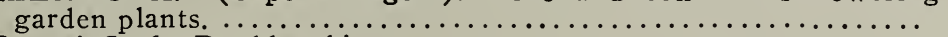

Pongei, fl. pl. Double white. . . . . . . . . . . . . . . . . . . . .

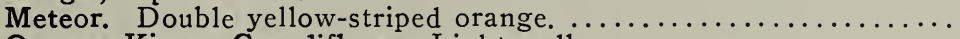

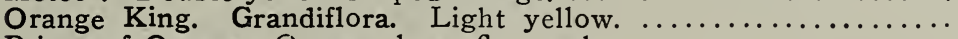

Prince of Orange. Orange, large-flowered. . . . . . . . . . . . . . .

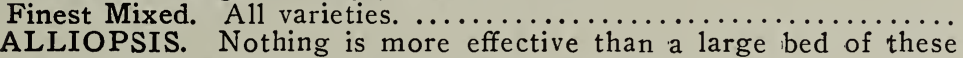
golden flowers; exceedingly free-flowering.

Golden Ray. Dwarf compact plants. Golden yellow and maroon...

Golden Wave (Drummondi). Pure yellow flowers, very large and showy.

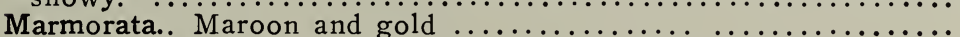

Dwarf. Finest Mixed. All shades of yellow, red and brown. ......

CALLIRHOE involucrata. (Poppy Mallow). Beautiful trailing plant, with palmate foliage; flowers large, crimson, with white center...

CAMPANULA Carpatica. Deep blue; for rockeries, beds and edgings

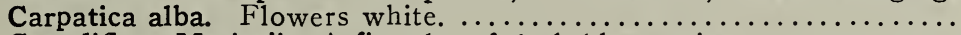

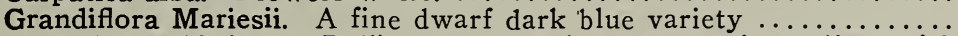

Pyramidalis (Chimney Bell). Very conspicuous towering spikes, with

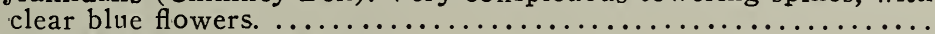

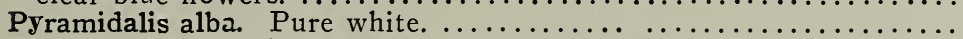

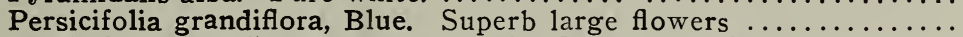

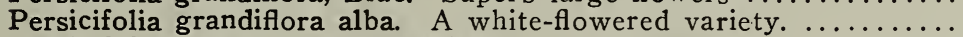

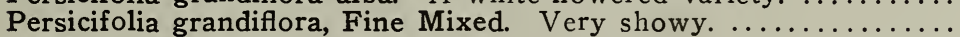

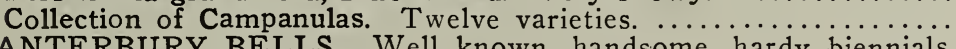

CANTERBURY BELLS. Well known, handsome, hardy biennials, bearing large bell and saucer-shaped flowers in profusion; well

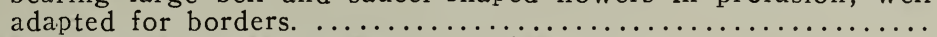

Medium Blue, Rose, Striped and White separate $\ldots \ldots \ldots \ldots \ldots \ldots$

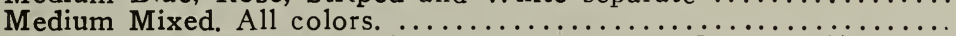

Medium Double Blue. Rich, heavy, curious flowers. $1 / 4$ ounce

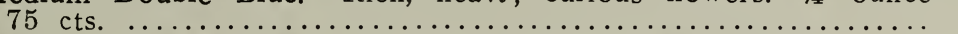

Medium Double White. Of waxen appearance $1 / 4$ ounce 75 cts.....

Medium Double Rose. $1 / 4$ ounce, 75 cts. ....................

Medium Double Mixed. $1 / 4$ ounce 75 cts. . . . . . . . . . . . . . . . .

Medium Calycanthema. "Cup and Saucer," Blue. $1 / 4$ ounce, 75 cts...

Medium Calycanthema. "Cup and Saucer." 1/4 ounce, 75 cts. .....

Medium Calycanthema. "Cup and Saucer." White. 1/4 ounce, $7 \dot{5} \mathrm{cts}$..

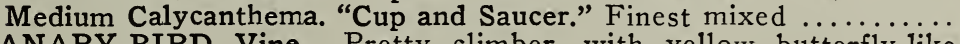

CANARY-BIRD Vine. Pretty climber, with yellow butterfly-like

flowers. $\ldots \ldots \ldots \ldots \ldots \ldots \ldots \ldots \ldots \ldots \ldots \ldots \ldots \ldots \ldots \ldots \ldots$
beds or for edging; also grown extensively for cut-flowers. $\ldots . .$.

Coronaria Empress. A large-flowered variety of purest white, grown

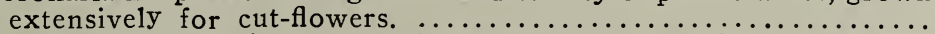

Coronaria Little Prince. Very large heads of pure white flowers ...

Coronaria Giant Hyacinth-Flowered. White. ................

Queen of Italy. Compact bushes with very large pink flowers. ....

Rose Cardinal. Bright rosy cardinal, a rich and striking color. ....

The Pearl. A very fine pure white; of branching habit. ..........

Umbellata Dunnetti. Dark crimson $\ldots \ldots \ldots \ldots \ldots \ldots \ldots \ldots \ldots \ldots \ldots \ldots$

Umbellata lilacina. Lilac-purple. $\ldots \ldots \ldots \ldots \ldots \ldots \ldots \ldots \ldots \ldots$

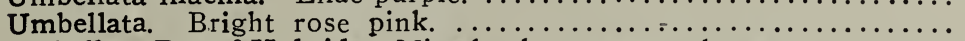

Umbellata Dwarf Hybrids. Mixed colors; neat and pretty ..........

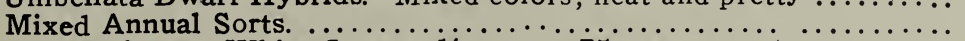

Sempervirens. White flowers $1 / 4$ ounce, 75 cts. $\ldots \ldots \ldots \ldots \ldots \ldots \ldots$

Gibraltarica. Beautiful bluish-white $1 / 4$ ounce, $\$ 1.00 \ldots \ldots \ldots \ldots \ldots \ldots$

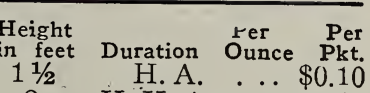

H. H. A. $\quad \ldots r \quad .10$

T. A. $\$ 0.30 \quad .05$

H. A. $\quad .30 \quad .05$

H. A. C. . .

.10

2 G. $P$

$\because \ldots \ldots \quad \ldots \quad 1.00$

1 G. P. . . . 50

1 H. A.

.... . .25 .0F,

… $.25 \quad .05$

$\ldots \ldots . .25 \quad .05$

$\ldots \ldots . .25 \quad .05$

$\ldots \ldots . .20 \quad .05$

$\ldots \ldots \ldots \quad . .25$

H. A. $.00 \quad .05$

1 H. A. .30 .05

$\begin{array}{llll}11 / 2 & \ldots \ldots & .30 \quad .05\end{array}$

$1 \quad \ldots \ldots . \quad .25 \quad .05$

1 H. P. .75 .05

$\begin{array}{llll}1 / 2 & \text { H. P. } & .60 & .10\end{array}$

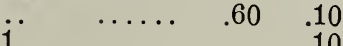

․ H. P. $\quad .75 \quad .10$

$4 \quad \ldots \ldots \ldots \quad 1.00 \quad .10$

$2^{2}$

2

$\ldots \ldots . .25$

Н. $\ddot{\mathrm{P} .} \quad \cdots \quad .65$

H. B.

$\ldots \ldots . .50 \quad .05$

$\ldots \ldots .50 \quad .05$

$2 \quad \ldots . \cdots 200$

.10

$2.00 \quad .10$

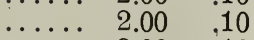

$\ldots \ldots 2.00 \quad 10$

H. B. $2.50 \quad .10$

.... $2.50 \quad .10$

$\ldots \ldots .2 .50 \quad .10$

.... $2.00 \quad .10$

H. A. 'C. $.30 \quad .05$

H. A.

$1 / 2$

$1 / 2$

$3 / 4$

1

1

1

1

$1 / 2$

1

$\begin{array}{lrr}\ldots \ldots & .40 & .05 \\ \ldots \ldots & 1.00 & .10 \\ \ldots \ldots & .40 & .10 \\ \ldots \ldots & .50 & .10 \\ \ldots \ldots & 1.50 & .10 \\ \ldots . . & 1.00 & .10 \\ \mathrm{H} . \mathrm{A} . & .25 & .05 \\ \ldots \ldots & .25 & .05 \\ \ldots \ldots & .35 & .05 \\ \ldots \ldots & .60 & .10 \\ \dddot{\mathrm{H}} . \mathrm{P} . & .25 & .05 \\ \mathrm{H} . \mathrm{P} . & 3.00 & .10 \\ & & .10\end{array}$




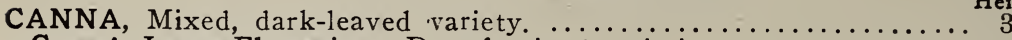

Crozy's Large-Flowering. Dwarf, mixed varieties. . . . . . . . . . . . 2

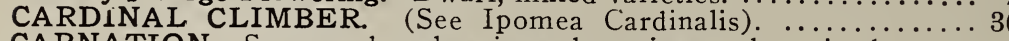

CARNATION. Sown under glass in early spring, or later in the open ground, the plants will flower second summer.

Marguerite (Dianthus Caryophyllus, fl. pl.) The perpetual-flowering Carnations produce a large proportion of double flowers in six months from sowing.

Marguerite, Double White. Large, perfect flowers. ........ $11 / 2$

Marguerite, Double Yellow. A clear soft shade. ............... $11 / 2$

Marguerite, Double Tall Mixed. All colors. $1 / 4$ ounce, $50 \mathrm{cts} \ldots \ldots \ldots \ldots 11 / 2$

Marguerite, Giant Double. Extra large and perfect-flowering, in a rich variety of colors. $1 / 4$ ounce, 75 cts. $\ldots \ldots \ldots \ldots \ldots \ldots \ldots \ldots \ldots 11 / 2$

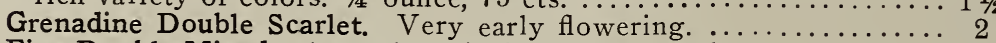

Fine Double Mixed. A good strain for out-door culture........... 2

Finest Double Mixed. Saved from extra fine flowers. . . . . . . . . . . . ${ }_{2}$

Chabaud's Everblooming. Blooms in five months after being sown, and continues to flower in the greatest profusion indefinitely.

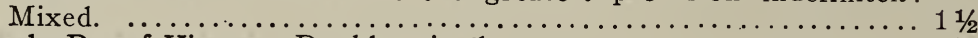

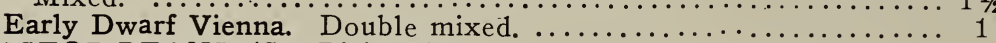

CASTOR BEANS. (See Ricinus.)

CELOSIA CRISTATA, or COCKSCOMB. Popular annual of easy

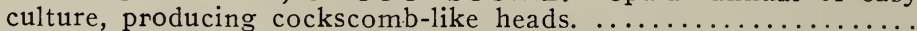

Childsi. Chinese Wool Flower. (See novelties).

Empress. Crimson combs; dark foliage. $1 / 4$ ounce, $\$ 1.00 . \ldots \ldots \ldots$

Glasgow Prize. Large deep crimson. $1 / 4$ ounce, $\$ 1.00 \ldots \ldots \ldots \ldots \ldots$.

Queen of the Dwarfs. Very dwarf forni, deep crimson. $1 / 4$ ounce,

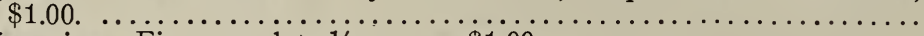

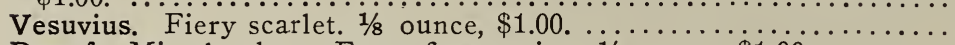

Dwarf. Mixed colors. Extra fine strain. $1 / 4$ ounce, $\$ 1.00 . \ldots \ldots \ldots$

Collection of Six Dwarf Varieties. $\ldots \ldots \ldots \ldots \ldots \ldots \ldots \ldots \ldots$ graceful plumes. Make fine plants for large beds or groups, and the plumes or flowers can be cut and dried for winter bouquets. ....

Pyramidalis Magnifica Aurea. Golden-yellow plumes. ...........

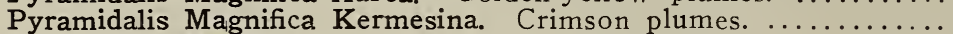

Pyramidalis Magnifica Coccinea. Scarlet plumes. ...............

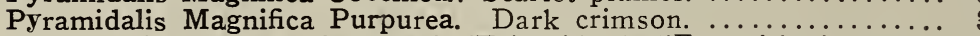

Pyramidalis Thompson's Superb (Triomble de 1'Exposition). Of pyramidal growth and producing graceful, feathery plumes; dwarf habit, dark crimson.

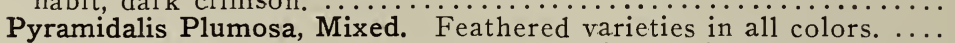

Pride of Castle Gould. All shades in choicest mixture; branching habit.

Spicata. Rose changing to silvery white. fine for pots or cutting.

CELSIA ARCTURUS. Long spikes of bright yellow flowers. .....

CENTUREA. Beautiful silvery foliaged bedding plants; used for bordering.

Candidissima. Round, compact plants; white leaves, broadly cut. $\ldots 1_{1 / 2}^{1}$

CENTAUREA. They flower finest in full sun and poor soil. Sow in the open ground in spring.

Americana. Bushy garden plants; lavender-blue; fragrant. ....... 3

Chameleon. Large; yellow and rose. ........................

Margaritae. Pure white, $2 \frac{1 / 2}{2}$ inches across, exquisitely laciniated and delightfully scented.

Montana. Large flowers of deep purple, very showy. . . . . . . . . . .

Montana alba. Large flowered, pure white. ................. 2

Moschata. Purple Sweet Sultan. ..........................

Moschata Alba. White Sweet Sultan. .................... $11 / 2$

Moschata. Mixed Sweet Sultan. ........................

Suaveolens. Yellow Sweet Sultan. Fine for cutting. . . . . . . . . . . $11 / 2$

CENTAUREA Cyanus (Bachelor's Button,, Corn-flower, Blue Bottle, or Ragged Sailor). This is one of the most popular annuals; will grow in the poorest of soil, either on seashore or mountains.

Emperor William. The true deep blue Bachelor's Button. ........ $111 \%$

Rosea. Rose-pink.

Finest Mixed.

Collection of Six Varieties Centaurea Cranus.

CENTAUREA IMPERIALIS Giant Imperial Sweet Sultans. The finest of all Sweet Sultans for cut-flower purposes.

Separate Colors. Lilac, White, Pink with White center, Purple, Rose.

IIinest Mixed. All colors.

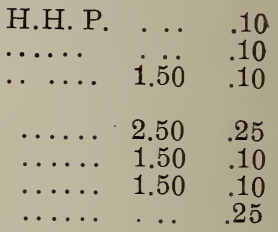

$\cdots \cdots$

$\dot{2} .00 \quad .10$

H. H. A.

\begin{tabular}{|c|c|}
\hline$\ldots \ldots$ & $\cdots$ \\
\hline$\ldots \ldots$ & $\cdots$ \\
\hline$\cdots \cdots$ & . \\
\hline$\cdots \cdots$ & \\
\hline$\cdots$ & \\
\hline$\cdots \ldots$ & \\
\hline ... & \\
\hline
\end{tabular}

H. H. A.

$\begin{array}{lll}\ldots \ldots & 2.00 & .10 \\ \ldots \ldots & 2.00 & .10 \\ \ldots \ldots & 2.00 & .10 \\ \ldots \ldots & 2.00 & .10\end{array}$

3

\begin{tabular}{|c|c|}
\hline & 1.50 \\
\hline$\ldots \ldots$ & 1.25 \\
\hline & \\
\hline G. P. & \\
\hline
\end{tabular}

H. H. P. $4.00 \quad .10$

$\begin{array}{lll}\ldots \ldots & 1.00 \quad .10\end{array}$

H. A. $\quad 1.00 \quad .10$

.... $2.00 \quad .10$

․… 100

H. P. $1.00 \quad .15$

H. P. $1.50 \quad .15$

H. A. $\quad .40 \quad .05$

.... .40. .05

$\ldots \ldots .40 \quad .05$

... . .50 .05

H. A.

.... .25 .05

.... .25 .05

$\cdots \cdots \quad .25 \quad .05$

H. H. A.

\section{5} 10

\section{0} , 
CENTROSEMA grandiflora (Butterfly Pea). Flowers purple and fin feet white.

CERASTIUM Tomentosum. Hardy, silvery-leaved.

CHRYSANTHEMUM, Annual Varieties. Showy, hardy annuals of easiest cultivation and blooming from July until frost.

Coronarium Compactum. White Pearl. Fine for cutting. ........

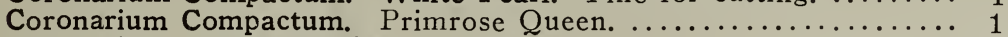

Coronarium, Double White. .......................... $11 / 2$

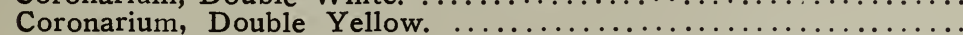

Coronarium, Double Mixed. Yellow, white, etc. ....................

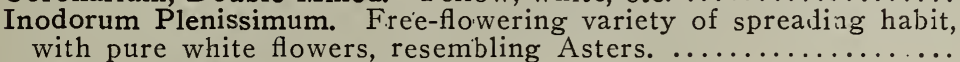

with pure white flowers, resembling Asters. $\ldots \ldots \ldots \ldots \ldots \ldots \ldots$

Tricolor, Double-fringed Mixed. This is a very graceful flower.

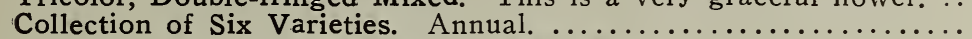

CHRYSANTHEMUM, Perennial Varieties.

Frutescens. The White Paris Daisy. Charming plant for greenhouse or summer bedding out doors. ................... $11 / 2$

Japonicum fl. pl. From finest Japanese flowers. Extra choice mixture 3

Maximum. "Perfection." Very free-flowering; pure white. ....... 1/2

Maximum. "Princess Henry." Compact growth; well formed : white flowers. ...........................

Leucanthemum hybridum. (The Shasta Daisy). Pure white; very

Leucanthemum Alaska. Pure white, with broad overlapping petals...

Leucanthemum hybridum California. Large creamy yellow flowers 3

CINERARIA, maritima candidissima. A white-leaved "Dusty Miller," used for bedding.

CINERARIA hybrida. One of the most gorgeous colored flowering plants for either greenhouse or conservatory. Seeds should be sown in July, August or September.

Marshall's Matchiess Prize Mixed. Every shade of blue, crimson, violet and pink, both in self colors and with white edge or center: The flowers are often $3 \mathrm{in}$. in diameter and the plants of excellent habit.

Grandiflora, Matcheless Dwarf Prize Mixed. This strain is just as choice as above, but different in height. ................. $11 / 2$

Stellata hybrids, Mixed Colors. Tall pyramidal plants, bearing star-

like flowers. …............................................... proved in recent years, and the varieties offered below are now seen as cut-flowers in most of the large cities of Europe; they do well either in sun or shade.

Brilliant. Double salmon-scarlet flowers. .................

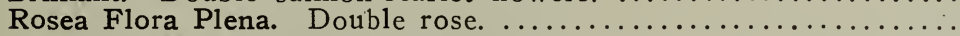

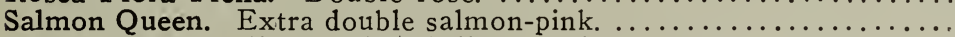

Scarlet Queen. Fine double, brilliant salmon orange scarlet. .....

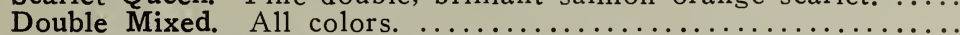

CLIANTHUS, Dampieri (Austrian Glory Pea). Scarlet flowers. .

CLEOME, Gigantea. (Spider Plant). Spider-like clusters, rose color

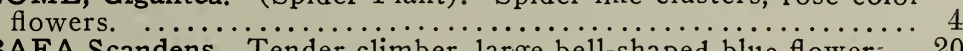

COBAEA Scandens. Tender climber, large bell-shaped blue flower: .. 20

White. Large white bell-like flowers. $1 / 4$ ounce, 50 cts. ...........

COCCINEA Indica. Annual climber, scarlet fruits, mottled white... 10

COCKSCOMB. (See Celosia Cristata).

COLEUS, Choice Mixed. Richly colored foliage. ............ 2

COLLINSIA. Charming annual. Finest mixed. $\ldots \ldots \ldots \ldots \ldots \ldots \ldots \ldots$.

COLUMBINE. (See Aquilegia).

CONVOLVULUS, or Morning Glories. (See also Morning Glory). Deservedly very popular, as they are of the most free-flowering and rapid growing plants in cultivation, thriving in almost any situation

Major, Mixed Colors. Climbers of rapid growth. ............ 30

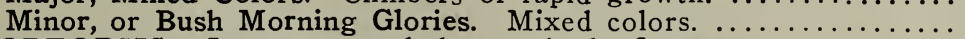

COREOPSIS. Long-stemmed, lange, single flowers. . . . . . . . . .

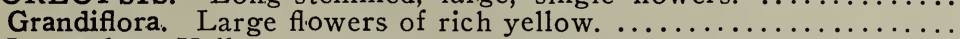

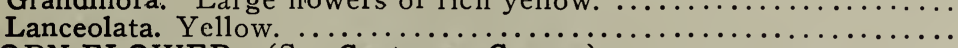

CORN-FLOWER. (See Centaurea Cyanus) $\ldots \ldots \ldots \ldots \ldots \ldots \ldots \ldots \ldots$

COSMOS. This is one of our most useful and beautiful autumn flowers. To get it in bloom early, seed should be sown in May in the open ground where the plants are desired to bloom, and the seedings allowed to grow and flower without being transplanted.

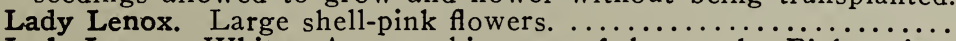

Lady Lenox. White. A pure white type of the popular Pink variety

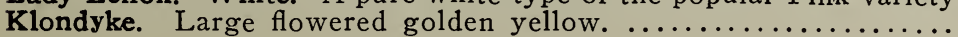

$\begin{array}{crlr}\text { feet } & \text { Duration } & \begin{array}{l}\text { Per } \\ \text { Ounce }\end{array} & \begin{array}{c}\text { Per } \\ \text { Pkt. }\end{array} \\ 8 & \text { H. C. } & \ldots & \$ 0.10\end{array}$

$1 / 2$

H. P. $\quad \cdots \quad r 25$

H. A. $\$ .50$

.... $\quad .50$

$\ldots \ldots .30$

$\ldots \ldots .30$

$\ldots . .30$

$\ldots \ldots .75$

$\begin{array}{lr}\ldots \cdots & .75 \\ \cdots \cdots & .40 \\ \cdots \cdots & 75\end{array}$

...... . . 30

G. P.

G. P.

H. P.

. . .10

H. P. 1.00

$\dot{1} .00$

.25

H. P. 1.ちi)

.16

$\ddot{\mathrm{H}} \ddot{\mathrm{P}}$. $\quad$ i. $\dot{5} 0$

.10

H. H.P. $\quad .50$

.05

H. A. 1.50

.10

$\begin{array}{lr}\text { H... } & .50 \quad .50 \\ \ldots & .50\end{array}$

$\ldots \ldots \quad .50 \quad .10$

.... $2.00 \quad 10$

$\because \ddot{\mathrm{G}} . \mathrm{S} . \quad .50 \quad .050$

H. A. $.60 \quad .10$

H. A. C. $.75 \quad .10$

…. $1.50 \quad .15$

G. P. . . .10

H. A. $.30 \quad .05$

10

.05

5

15

0
5
0
0
0
5
0

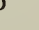


Cosmos ('Continued).

NAME AND DESCRIPTION.

Height

in feet

Giant Early Flowering. Crimson. $1 / 4$ ounce, 30 cts. ......... 4

Giant Early Flowering. Pink. $1 / 4$ ounce, 30 cts. $\ldots \ldots \ldots \ldots \ldots \ldots$

Giant Early Flowering. The Bride. White tinted pink. ...........

Giant Early Flowering. White. $1 / 4$ ounce, $30 \mathrm{cts} . \ldots \ldots \ldots \ldots \ldots$

Giant Early Flowering. Mixed colors; compact, bushy growth. ..

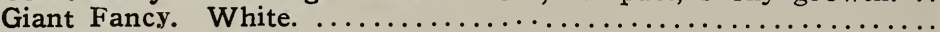

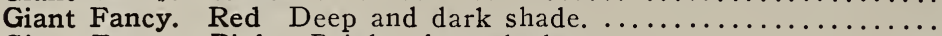

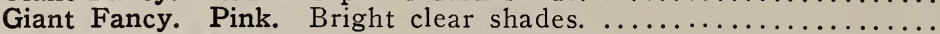

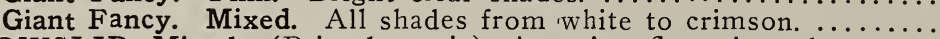

COWSLIP, Mixed (Primula veris). A spring flowering plant......

CUPHEA, Platycentra (Cigar Plant). Valuable as a bedding and border plant. The flowers are scarlet with a black and white lip..

CYCLAMEN. These are among the choicest of flowering greenhouse plants. Seed should be sown from October until January. ......

Marshall's Giant Varieties. Persicum Giganteum.

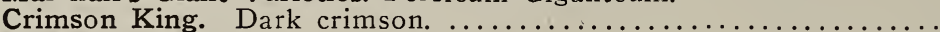

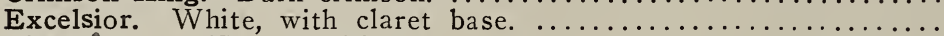

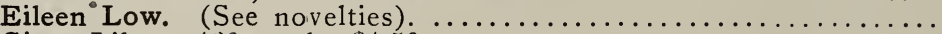

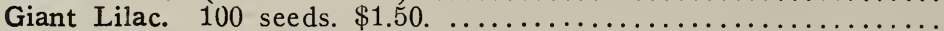

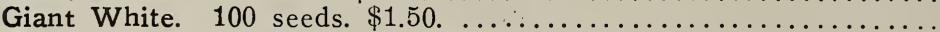

Mrs. Buckston. Salmon-pink, heavily fringed. ................

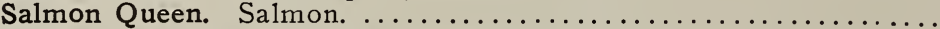

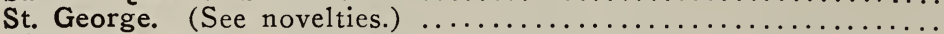

Victoria. A pretty form with colored fringe at the top of the petals. In several colors.

Marshall's Giant Mixture. Includes all the brilliant colors. 100 seeds. $\$ 1.50$.

CYPERUS, Alternifolius (Umbrella Plant). Handsome plants, easily raised from seed used for table decorations and combining with

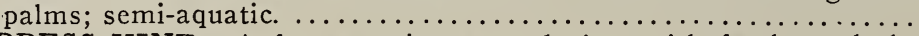

CYPRESS VINE. A fast growing annual vine, with feathery dark-

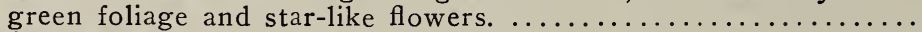

Bright Scarlet.

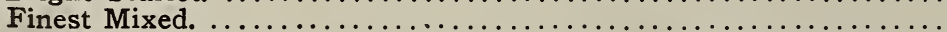

DAHLIA. Although perennials, these will flower the first season. ... Double, Large Flowering. Double mixed colors. $1 / 4$ ounce, 50 cts... Cactus. New choice varieties. Mixed colors. $1 / 8$ ounce, $35 \mathrm{cts} . . .$. Single, Large Flowering. Mixed. Self and stripped flowers. ....... DAISY, Double. (See Bellis Perennis).

DATURA (Trumpet Flower). Robust garden annual, bearing large

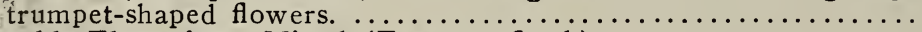

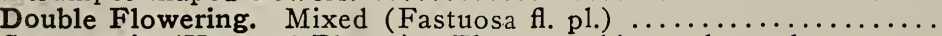

Cornucopia (Horn of Plenty). Flowers white and purple ........

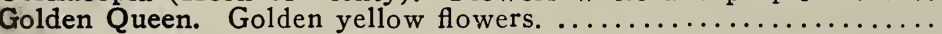

DELPHINIUM (Larkspur). Larkspurs are hardy and can be grown in any garden. They are handsome plants for the herbaceous border and shrubbery, and are splendid for cut-flower use. ........

Belladonna. Very large-flowered, light azure blue. ..............

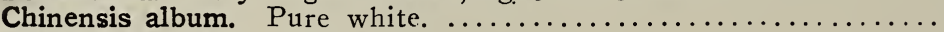

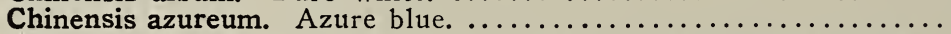

Chinensis Mixed (Grandiflorum). Shades of blue and pure white...

Elatum, Blue (See Larkspur). Soft, clear blue flowers in tall spikes.

Elatum hybridum, Finest Mixed. Very showy.

Formosum. Brilliant blue, white center; especially fine and attractive

Formosum coelestinum. Sky-blue; handsome. ................

Hybridum Grandiflorum fl. pl. Finest double sorts in choice colors; superb mixture. $1 / 4$ ounce, $\$ 1.00$.

Marshall's Matcheless Hybrids. Choice show Hybrids, saved from

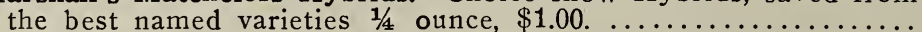

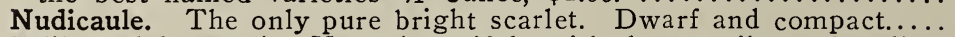
Zalil (sulphureum). Very beautiful, with long spikes of yellow

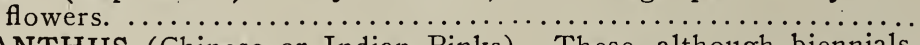

DIANTHUS (Chinese or Indian Pinks). These, although biennials, bloom the first season, and should be treated as hardy annuals. They flower early in summer and continue until frost. They are excellent for small beds or edgings, flowering profusely and in great variety of colors.

SINGLE ANNUAL PINKS.

Heddewigii. Lange, attractive flowers of most brilliant colors. Finest mixed.

Laciniatus Single Mixed. Fringed flowers of all colors. . . . . . .
4

$\cdots$

$1 / 2$

Per Per
Duration Ource

$\ldots \ldots \$ 1.00 \$ 0.10$

$\ldots \ldots+1.00 \quad .10$

$\ldots \ldots .1 .00 \quad .10$

$\ldots \ldots \quad 1.00 \quad .10$

$\ldots \ldots 1.00 \quad 1.00$

$\ldots . .60 \quad .60$

$\ldots . . .40 \quad 10$

. . . . .

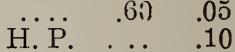

1 H. H.P. ... . .25

$1 / 2$ G. P.

$\ldots \ldots . .50$

$\ldots \ldots . .50$

$\ldots \ldots . .50$

$\ldots \ldots . .50$

$\ldots \ldots . .50$

$\ldots \ldots . . .50$

$\cdots \cdots+. .50$

$\ldots \ldots . .50$

.50

2 H. H. P.

20 H. A. C.

.......

H.. H.P.

.40

.30

.05

.05

.....

1.50

.io

..... 2.00

$\ldots . . .1 .00$

.10

.10

H. H. A.

.....

.30

.05

......

.30

.05

H. P.

......

$\ldots \ldots$

$\ldots .$.

$\ldots \ldots$

$\ldots \ldots$

$\ldots \ldots$

$\ldots \ldots$

$\ldots .$.

3.00

.25

.25

.25

.25

H. H. A.

... 
Dianthus Chinensis fl. pl. (Chinese Pink). Large, double flowers

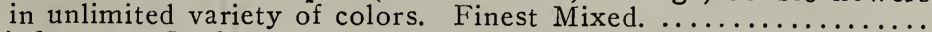

Diadematus, fl. pl. (Double Diadem Pink). Large, double flowers. Mixed.

Heddewigii fl. pl. (Japanese Pink). Large, double flowers of ex-

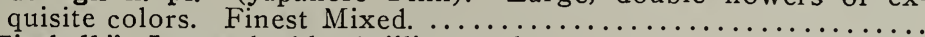

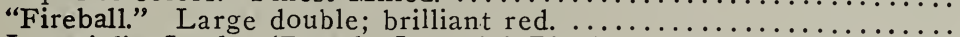

Imperialis f. pl. (Double Imperial Pink). Variegated flowers of

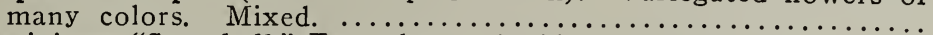

Laciniatus "Snowball." Extra large, double, pure white. . . . . . . . . . . .

Laciniatus fl. pl. Double fringed flowers; beautifully striped; many

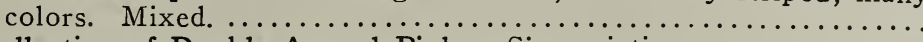

Collection of Double Annual Pinks.. Six varieties. . . . . . . . . . .

HARDY PERENNIAL PINKS.

Plumaris fl. pl. Pheasant's Eye. Fretty fringed double flowers. ...

Plumarius Scoticus. (Double Scotch Pink). Mixed. ..............

Plumarius semperflorens. (Perpetual Pink). Mixed, single and

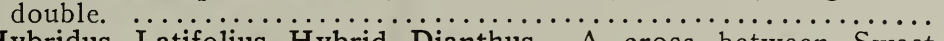

Hybridus Latifolius Hybrid Dianthus. $A$ cross between Sweet

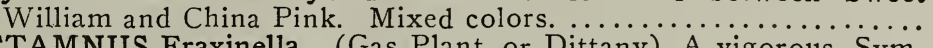

DICTAMNUS Fraxinella. (Gas Plant, or Dittany). A vigorous, metrical plant with glossy foliage and large Howers. Mixed. ...

DIGITALIS, or Foxglove. Hardy perennials, producing long spikes

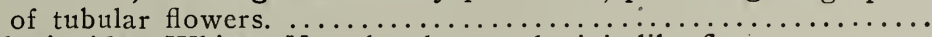

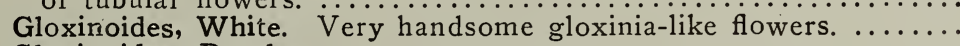

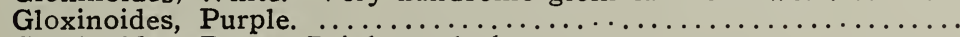

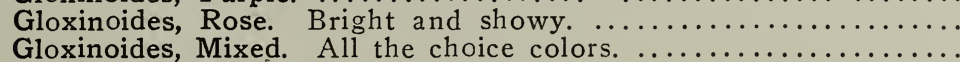

Monstrosa, Mixed. Very large flowers. . . . . . . . . . . . . . .

All Varieties Mixed. Common Foxglove. $\ldots \ldots \ldots \ldots \ldots \ldots \ldots \ldots \ldots$ orange color; the disc is dark and surrounded by a black zone. ....

Aurantiaca Hybrida. Mixed hybrids. $\ldots \ldots \ldots \ldots \ldots \ldots \ldots \ldots \ldots \ldots$

Aurantiaca Hybrida Flora Plena. Semi double and double mixed

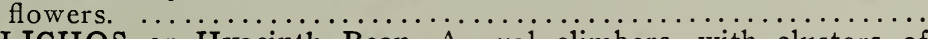

DOLICHOS or Hyacinth Bean. Annual climbers, with clusters of

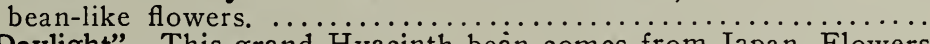

"Daylight". This grand Hyacinth bean comes from Japan. Flowers pure white; pea shaped. .......................................

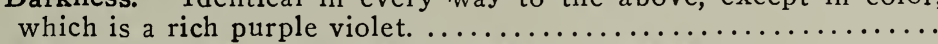

Lablab. Separate colors. Red, White and Violet each. ...........

Lablab, Mixed. Purple and White.

Doronicum Caucasicum. Effective spring flowering plant, with

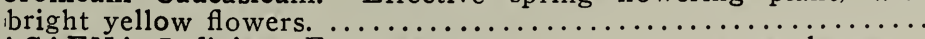

DRACAENA, Indivisa. For vases, pots, etc., narrow green leaves ..

ECHEVERIA. A showy plant, for rockeries or carpet beds. .....

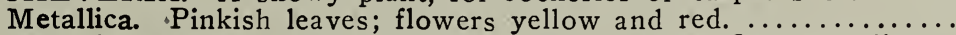

Secunda Glauca. Small bluish-white fleshy leaves; flowers yellow...

ECHINOCYSTIS Lobata. (Wild, or California Cucumber). The fastest growing annual vine in existence; will grow 20 feet in six

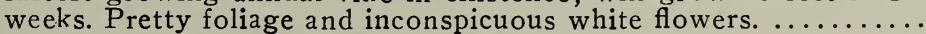

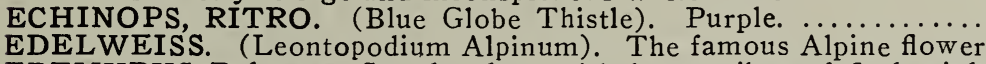

EREMURUS Robustus. Stately plant with long spikes of flesh pink flowers.

ERYNGIUM Amethystinum. (Sea Holly). Spiny folliage and small

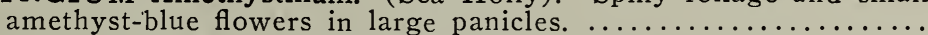

ERINUS ALPINUS. Blue; beautiful for baskets. . . . . . . . . . . . .

ESCHSCHOLTZIA, or California Poppy. Very attractive annuals for beds, edgings, or masses; prufuse-flowering, fine cut, glaucous foliage; in bloom from June to Frost.

Californica. Bright yellow.

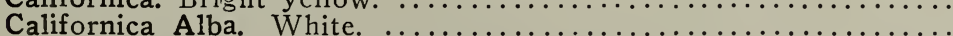

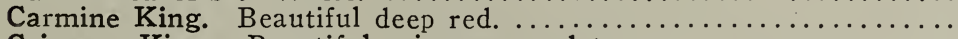

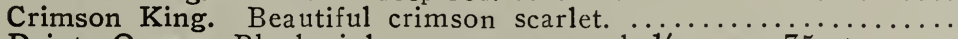

Dainty Queen. Blush-pink on cream ground. $1 / 8$ ounce 75 cts. . . .

Golden West. Large flowers of deep yellow shade. .............

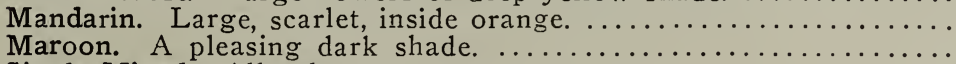

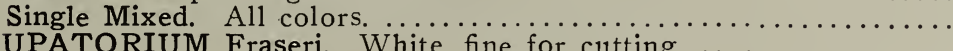

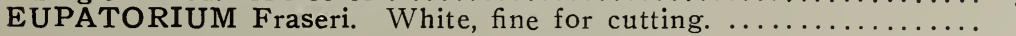

Height
in feet Der Per

1 H. A. $\$ 0.50 \$ 0.05$

$1 \quad \ldots \ldots .1 .00$

.10

1

.... 2.00

2.00
2.00

.10

.... $2.00 \quad .10$

1

$\begin{array}{lr}\ldots \ldots & .60 \\ \ldots \ldots & 2.00\end{array}$

.10

2.00

.10

1

1

H. P.

2.00

.30

1

1

1

.... 1.00

.10

.10

3

1.00

.10

H. P. .50

.10

H. P.

.....

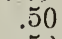

.50
.50

$\ldots \ldots$.

$\ldots . .50$

1.00

4
3

… $\quad .30$

.10

.10

.10

.05

.10

.65

$11 / 2 \quad$ H. A. 1.50

.10

$11 / 2$

......

.10

.25

10 H. A. C

$10 \quad \ldots \ldots . .25$

.10

$\begin{array}{ll}\ldots \ldots & .25 \\ \cdots \cdots & .20\end{array}$

.10

.05

.05

$2 H . P$

G. P.

G. P.

$\ddot{60}$

.25

.10

$1_{1 / 4}$

.25

$\begin{array}{cccc}20 & \text { H. A. C. } & .25 & .05 \\ 3 & \text { H. P. } & .30 & .10 \\ 1 / 2 & \text { H. P. } & . . & .10\end{array}$

8 H. P. ... .25

4 H. P. $\therefore . .10$

$1 / 4$ H. P.

.25

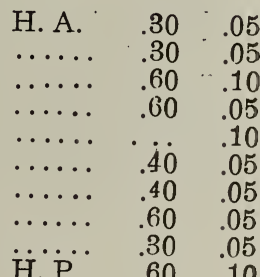

$2 \quad$ H. P. $\quad .60 \quad .05$ 
NAME AND DESCRIPTIÓN.

EUPHORBIA Heterophylla. (Fire on the Mountain). Leaves large and glossy green, often tipped with orange-scarlet. .............. Variegata. (Snow on the Mountain). White and green bracts; excellent for bouquets.

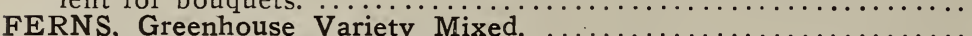

FEVERFEW. (See Matricaria.)

FORGET-ME-NOT. (See Myosotis).

FOX-GLOVE. (See Digitalis).

FOUR O'CLOCKS. (See Marvel of Peru).

FRANCOA Ramosa Hybrida Rosea. Long sprays of rose flowers...

FREESIA New Hybrids Mixed. Shades of pink, red, violet, yellow etc

GAILLARDIA. Showy garden annuals, with large flowers.

Amblyodon. Blood red.

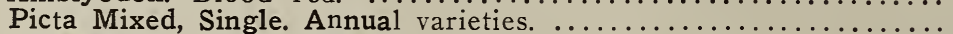

Lorenziana, Double Mixed.

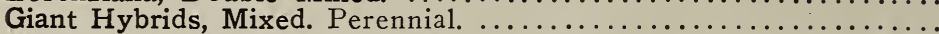

Marshall's Matcheless Hybrids. A grand new improved strain. enormous flowers and very strong habit. $1 / 8$ ounce, $\$ 1.00 . \ldots \ldots \ldots$.

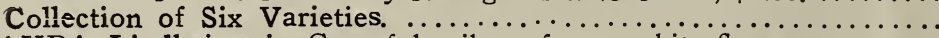

GAURA, Lindheimeri. Graceful spikes of rosy-white flowers. ........

GENTIANA Acaulis. (Gentian). Intense blue bell-shaped flowers..

GERANIUM. Well-known plants for garden or pot culture.

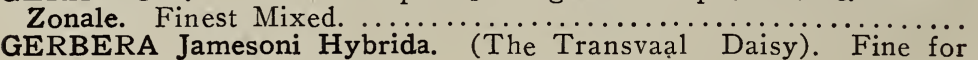

cut-flowers or bouquets. $\ldots \ldots \ldots \ldots \ldots \ldots \ldots \ldots \ldots \ldots \ldots \ldots \ldots \ldots \ldots \ldots \ldots \ldots \ldots$
GEUM Atrosanguineum. Large double crimson flowers. $\ldots \ldots \ldots \ldots$

GLOBE AMARANTH (Gomphrena). Clover-like heads of flowers;

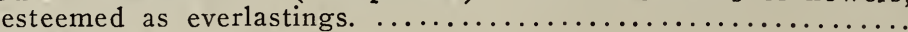

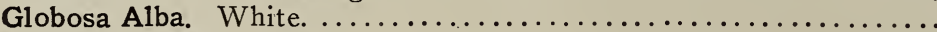

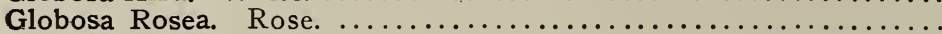

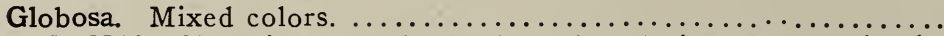

GLOXINIA. Charming pot plants, flowering during summer in the greenhouse or window.

Erect Giant Flowering, Mixed. Saved from choicest superb erect

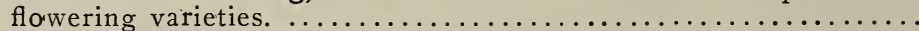

Marshall's Matcheless. Saved from the very choicest erect flower-

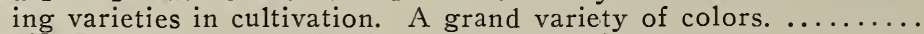

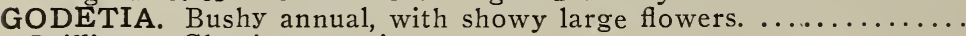

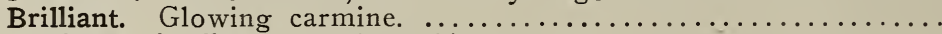

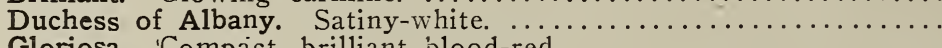

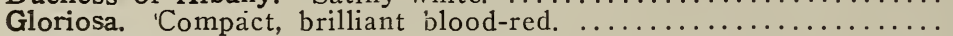

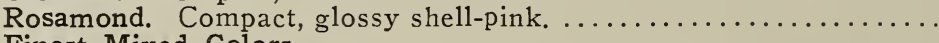

Finest Mixed Colors.

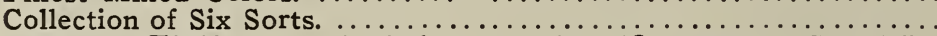

GOURDS. Thrifty annual climbers, bearing "Önamental Gourds"..

Apple-shaped.

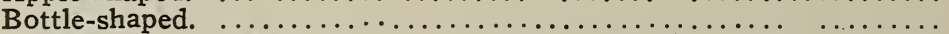

Dish-Cloth. (Chinese Loofa, or Sponge Gourd). Large, elongate fruit ;spongy inside. Flowers deep golden yellow. .............

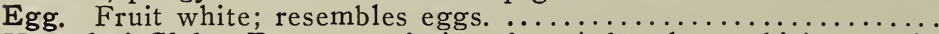

Hercules' Club. Enormous fruit; often 4 feet long, thicker at the

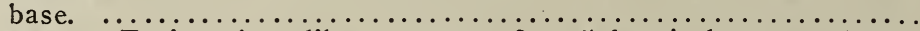

Serpent. Fruit striped like a serpent; 3 to 5 feet in length and very

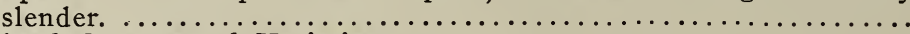

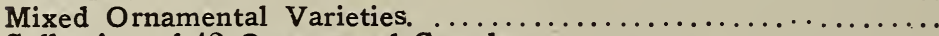

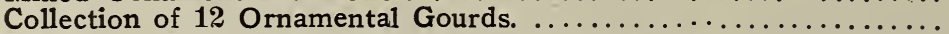

GRASSES, ORNAMENTAL. A most valuable class of plants for the lawn, shrub bed, border or tropical bed. The perennial varieties, many of which have varigated foliage, are excellent for borders, clumps on lawn or near ponds. The annual sorts are particularly pretty on account of the graceful feathery flower panicles, which are used in bouquets.

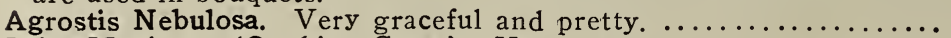

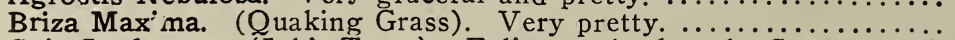

Coix Lachryma. (Job's Tears). Foliage quite broad. Seeds promi-

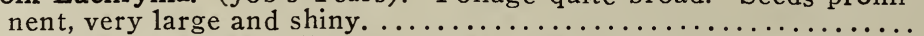

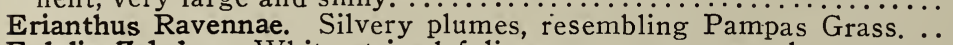

Eulalia Zebrina. White striped foliage, very ornamental. ........ Gynerium Argenteum. The famous Pampas Grass, with beautifui
Height
in feet Duration Ounce Pkt.

H. A. $\$ 0.60 \$ 0.10$

$2 \quad \ldots \ldots . \quad .30 \quad .10$

G. P. ... .2

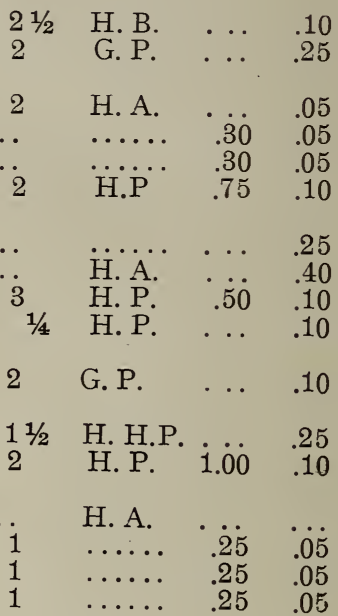

G. P.

$\cdots \quad . .6 . \quad .25$

4

10
H. A. C.

$\ldots \ldots$

$\ldots \ldots$

.30

$\therefore \ldots: \quad .30$

$\ldots \ldots .30$

.... 30

.05

.05

.....

.30

.05

.05

H. A.

.10

H. A.

H. A.

H. P.

.20

.60

.05

25

.50

io

.10

.10

.05

.30

.05

.05

.05

.50

H. P. .60

.10 
GRASSES. (Continued.)

NAME AND DESCRIPTION.

Height

Hordeum Jabatum. (Squirrel-tail Grass). A pretty variety, with

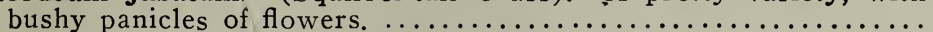

Pennisetum Longistylum. An annual grass, with gracefully dropping heads.

Pennisetum Ruppelianum. Hardy perennial grass, growing 3 feet high, with violet-tinted silvery plumes. The deep green foliage is

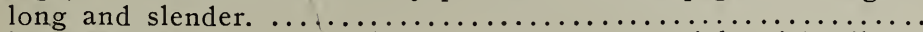

Stipa Pennata. (Feather Grass.) Hardy perennial, with silvery

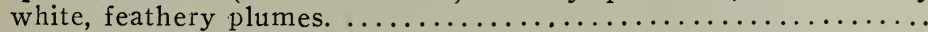

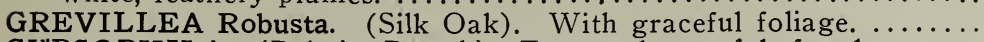

GYPSOPHILA. (Baby's Breath). Extremely useful for bouquets. Flowers small and come in delicate sprays and panicles.

Elegans Alba Grandiflora. An improved large-flowering, pure white form of the annual Baby's Breath, of free and easy growth......

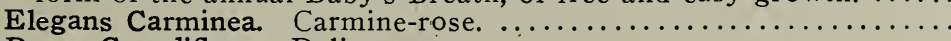

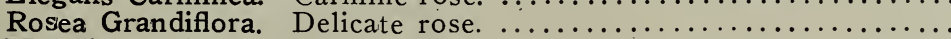

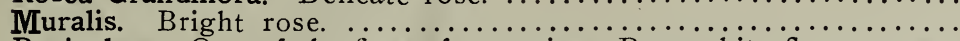

Paniculata. One of the finest for cutting. Pure white flowers, very

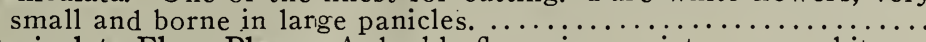

Paniculata Flora Plena. A double flowering variety; pure white. . HELIANTUS. (See Sunflower).

HELICHRYSUM, or Straw Flower. Large, double "everlasting" flowers.

Lange-Flowering, Double, Mixed Colors.

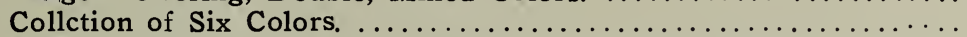

HELIOTROPE. Well known fragrant flowering plants for pots or

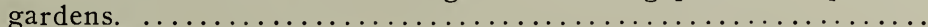

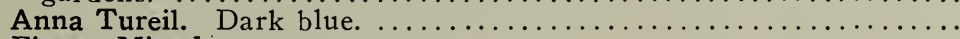

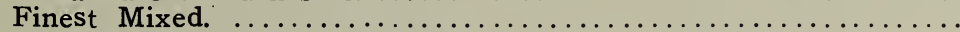

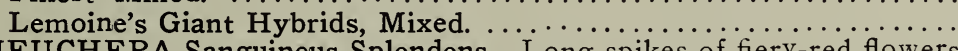

HEUCHERA Sanguineus Splendens. Long spikes of fiery-red flowers

HIBISCUS Africanus. Yellow with narrow center. . . . . . . . . . .

Moscheutos. (Swamp Rose Mallow). Flowers of a light rosy-red,

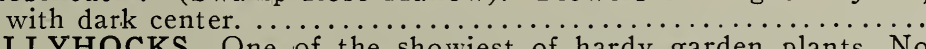

HOLLYHOCKS. One of the showiest of hardy garden plants. No garden is complete without these stately flowers. Hollyhocks are troubled of late with a rust, which can be prevented if plants are sprayed frequently in early spring with bordeaux mixture. ......

Double Apple Blossom. 1/4 ounce, $65 \mathrm{cts} . \ldots \ldots \ldots \ldots \ldots \ldots \ldots \ldots$

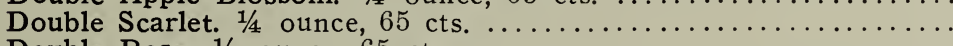

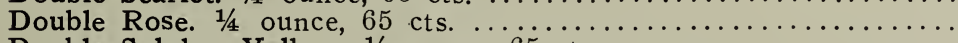

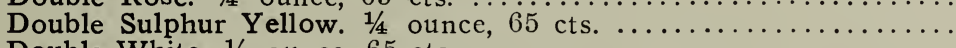

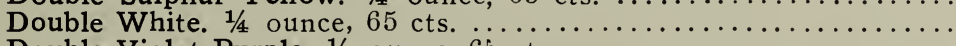

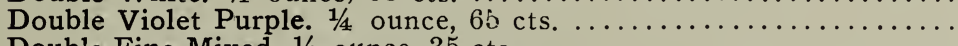

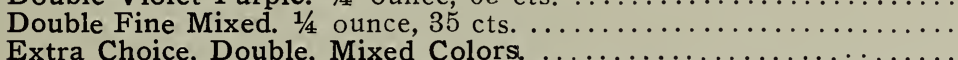

Extra Choice, Double, Mixed Colors $\ldots \ldots \ldots \ldots \ldots \ldots \ldots \ldots \ldots \ldots \ldots \ldots$.

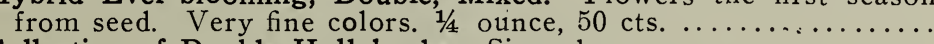

Collection of Double Hollyhocks Six colors. . . . . . . . . . . . .

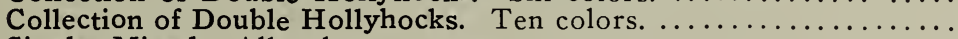

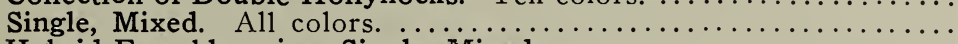

Hybrid Ever-blooming, Single, Mixed. $\ldots \ldots \ldots \ldots \ldots \ldots \ldots \ldots$

HONESTY. Lunaria Biennis. Has silvery seed pouches; used for

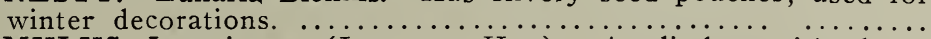

HUMULUS Japonicus. (Japanese Hop). A Alimber with $_{\text {Hense }}$ green foliage.

Japonicus Fol. Variegatis. Variegated foliage $\ldots \ldots \ldots \ldots \ldots \ldots \ldots$
HUNNEMANNIA Fumariaefolia. (Giant Yellow Tulip Flowers are tulip-shaped, pure golden yellow. When cut and put

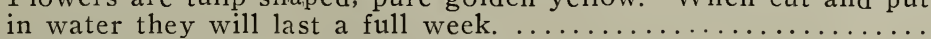

HYACINTH BEAN. (See Dolichos).

IBERIS. (See Candytuft).

ICE PLANT. (See Mesembryanthemum Crystallinum).

IMPATIENS. (Sultan's, or Zanzibar Balsam). Charming plants for decoration.

Sultani. Flowers of brilliant rosy-scarlet color. ........................... flowers. As pot plants they bloom the year round. 'Choicest

INCARVILLEA Delavayi. The flowers are borne on long, stout

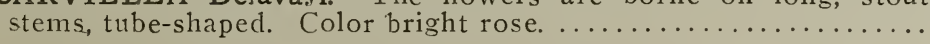

$3 \quad$ H. A. $\$ 0.50 \$ 0.10$

2 H. A. $\quad .30 \quad .10$

3 H. P. $\quad .50 \quad .10$

$2 \quad$ H. P. $\quad .60 \quad .10$

$5 \quad$ G. S. $\quad 1.50 \quad .10$

$\begin{array}{llll}11 / 2 & \text { H. A. } & .40 & .05 \\ 1 & \text { H. A. } & .50 & .10 \\ 11 / 2 & \text { H. A. } & .40 & .05 \\ 2 & \text { H. P. } & .50 & .10 \\ 2 & \text { H. P. } & .50 & .10 \\ 2 & \text { H. P. } & . . . & .25\end{array}$

$\begin{array}{llll}11 / 2 & \text { H. A. } & .60 \quad .05\end{array}$

....... . . 30

$11 / 2$ G. P.

.10

.10

.10

1 H. P.

.15

H. A. .25

.05

2
3

H. P. $\quad .50$

.05

H. P.

.... 2.00

2.00

.10

$\cdots \cdots, \quad 2.00 \quad .10$

..... $2.00 \quad .10$

$\begin{array}{lll}\ldots \ldots & 2.00 \quad .10\end{array}$

$\begin{array}{lll}\ldots \ldots & 2.00 \quad .10\end{array}$

$\ldots \ldots 2.00 \quad .10$

$\ldots \ldots .1 .00 \quad .05$

$\ldots \ldots 1.50 \quad .10$

$\ldots \ldots \quad 1.50 \quad .10$

$\ldots \ldots . .40$

$\ldots \ldots . .60$

$\ldots \ldots \quad 1.00 \quad .10$

.... $1.00 \quad .10$

2 H. B. $\quad .50 \quad .05$

30 H.A.C. $.40 \quad .05$

$\begin{array}{lll}\text { H.A.C. } & .40 & .05 \\ \ldots & .50 & .05\end{array}$

2 H. A. $\quad .60 \quad .10$

2 G. P

.25

2 H P

.10 
MARSHALL'S MATCHLESS SEEDS

Height

in feet

Duraticn Per Per

IPOMOEA Morning Glory. (See also Convolvulus). Climbers of rapid growth, with beautiful and varied flowers; for covering walls, trellises, arbors or stumps of trees they are invaluable........... Double "Snow Fairy." A beautiful climbing annual.

Cardinalis. "Cardinal Flower." A rapid growing annual with deep cardinal red flowers and laciniated foliage.

Grandiflora Alba. (Moonflower). Large, heart-shaped leaves and large pure white flowers, which open only late in the evening......

Rubro Coerulea. (Heavenly Blue). Beautiful, large, sky-blue flowers Setosa.(Brazilian Morning Glory) Large, ornamental foliage, with

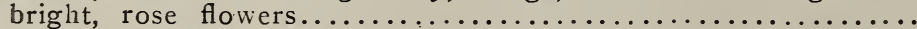

Imperial Japanese, Mixed. A great improvement over the old-

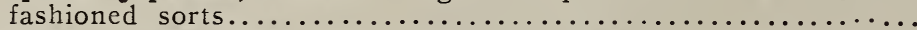

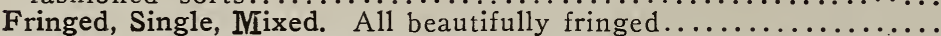

Japanese Double-Flowering, Mixed. Mixture of double sorts......

Quamoclit. (See CypressVine).

JACOBEA, Senecio. Finest Mixed. For large beds and borders.... KALANCHOE Flammea. Splendid greenhouse plant with large heads of orange scarlet flowers.

KENILWORTH IVY. Neat, hardy climber, clinging to walls, etc. ..

KOCHIA Tricophylla. (Belvidere Summer Cypress, or Mexican Firebush). Grows in a perfect pyramidal shaped cypress bush, with small feathery light-green foliage. Becomes a lovely crimson hue about September. ...................................

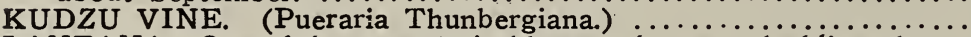

LANTANA. One of the most desirable greenhouse or bedding plants; constantly in bloom. Newest Hybrids, mixed. ...............

LATHYRUS Latifolius. Perennial Sweet Pea. Hardy climbers. Fine

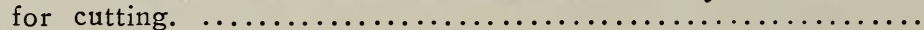

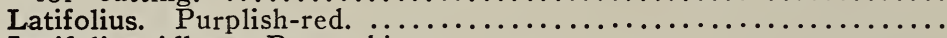

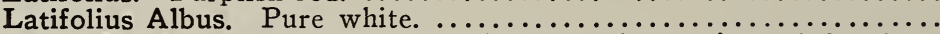

White Pearl. A large flowering, robust growing variety of the above

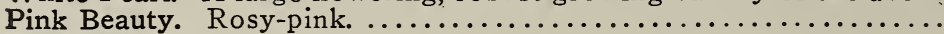

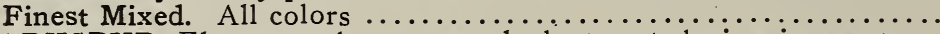

LARKSPUR. Elegant and ornamental plants, producing in great variety of form some of the most beautiful flowers in cultivation.

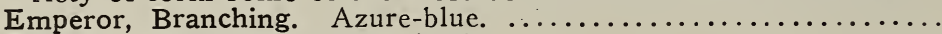

Emperor, Branching. Red-striped $\ldots \ldots \ldots \ldots \ldots \ldots \ldots \ldots \ldots \ldots \ldots \ldots \ldots \ldots$

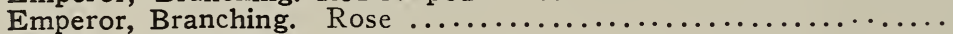

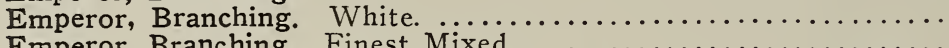

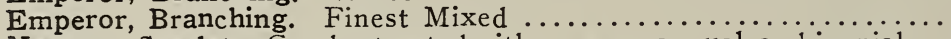

Newport Scarlet. Can be treated either as an annual or biennial...

Dwarf Rocket. Finest colors. Fine for bedding. ..............

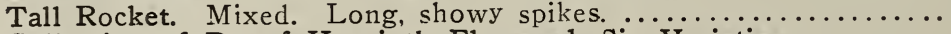

Collection of Dwarf Hyacinth Flowered, Six Varieties. ...........

Collection of Dwarf Hyacinth Flowered, Twelve Varieties. ........

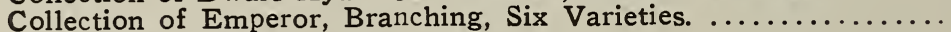
Perennial Larkspur. (See Delphinium).

LAVETERA splendens rosea. (Pink Mallow). Bushy plants; produce large, open, pink, mallow-like flowers in great profusion. ....

Splendens Alba. Large glossy white flowers. ................

LAVENDULA Vera. Sweet scented blue flowers. ................

LEMON VERBENA. (See Verbena).

LIATRIS Spicata. Very showy border plant with spikes of violet-

purple flowers. $\ldots \ldots \ldots \ldots \ldots \ldots \ldots \ldots \ldots \ldots$
LINARIA Cymbalaria. (See Kenilworth Ivy).
LINUM grandiflorum rubrum. Single, scarlet flowers. $\ldots \ldots \ldots \ldots \ldots \ldots \ldots$

LOBELIA. Bushy plants, with pendent branches; very profuse flowering. Fine for baskets or edging borders.

Erinus Crystal Palace, compacta. Dark blue. $1 / 4$ ounce, 50 cts. .... Erinus Emperor William. Light blue. $1 / 4$ ounce, $50 \mathrm{cts} . . . \ldots \ldots$. Erinus speciosa. Bright blue flowers. $1 / 4$ ounce, $40 \mathrm{cts} . \ldots \ldots \ldots \ldots$ Erinus gracilis. Blue flowers; trailing. $1 / 4$ ounce, $30 \mathrm{cts} . \ldots \ldots \ldots \ldots$

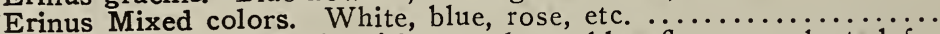

Tenuior. Upright habit with very large blue flowers; adapted for pots or borders. Perennial Varieties:

Cardinalis. ('Cardinal Flower). A native variety, with spikes of

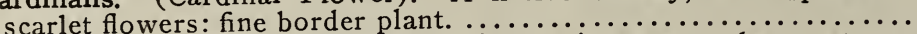
Illumination. "Cardinal Fulgens." Flowers intense scarlet on strong stems with bronze foliage.
20 H. A. 'C.

$20 \quad$.......

i0

-.....

$\$ 0.15$

$\ldots \ldots \$ 0.75 \quad .10$

$\ldots \ldots .50 \quad 10$

$\begin{array}{lll}\cdots \ldots & .50 \quad 10\end{array}$

15

$\begin{array}{lrr}\cdots \cdots & .25 & .05 \\ \cdots & .50 & .10\end{array}$

….. $1.00 \quad .10$

H. A. $1.00 \quad .05$

$11 / 2 \quad$ G. S. $\quad . .2 \quad .25$

6 H. P. $2.00 \quad .10$

H. A. $\quad .50 \quad .10$

H. P. $1.00 \quad .10$

2 G. S. $\quad .50 \quad .10$

8 H. P. $\quad .60 \quad .10$

$\begin{array}{llll}8 & . . .1 & .50 & .10\end{array}$

$\cdots \quad \cdots \cdots, \quad .60 \quad 10$

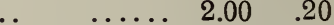

...... 60

… $\quad .40$

.10

2

H. A. $\quad .50 \quad .10$

..... .50 .10

$\begin{array}{lll}\ldots \ldots & .50 \quad .10\end{array}$

$\begin{array}{lll}\ldots \ldots & .50 \quad .10\end{array}$

$\begin{array}{lll}\ldots . . & .50 \quad .10\end{array}$

$\because \cdots, \quad .75 \quad .10$

H. A. $.30 \quad .05$

$\begin{array}{lll}\ldots . . . & .30 & .05\end{array}$

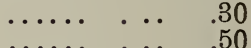

$\begin{array}{lll}\ldots \ldots & \cdots & .5 \\ \ldots \ldots & .50\end{array}$

3
3

H. A.

.50

.05

H. A. $\quad 1.00$

.10

H.P. $\quad .50 \quad .05$

2 H. P.

1 H. A.

.20

.05

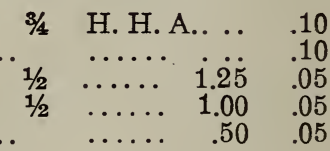

1 H. H. A. . .

.10

3 H. P.

H. P. 
NAME AND DESCRIPTION. Freight
in feet
Duration Ounce Per H. H. A. . . $\$ 0.10$

LOPHOSPERNUM, Scandens. Dark rose. A rapid-growing climber LOVE-LIES-BLEEDING. (See Amaranthus).

LOVE-IN-A-MIST. (See Nigella.)

LUPINUS . Free-flowering plants, with long spikes of flowers.

Hybridus, Insignis. Dark red.

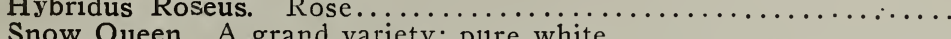

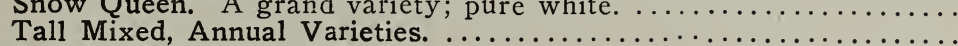

Mixed, Perennial Varieties.

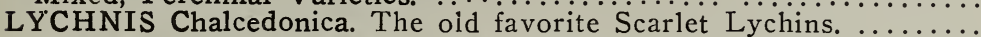

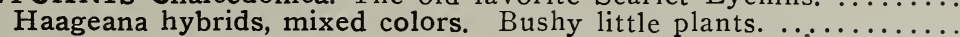

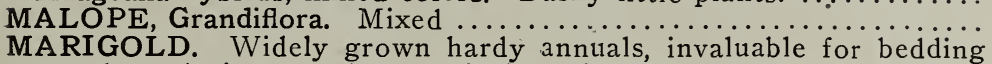
and producing an elegant display of yellow, orange and brown flowers from early summer till frost.

African Varieties.

Eldorado. Large, quilled, perfectly double; brilliant shades of yellow

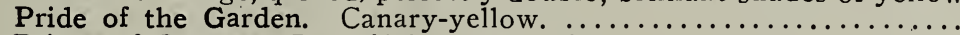

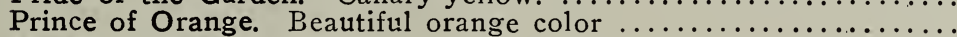

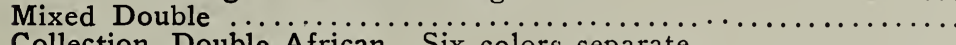

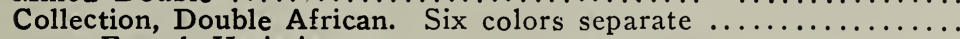
French Varieties:

Dwarf Gold Striped. Rich and quaintly striped double flowers.....

Legion of Honor Single yellow blooms, marked with red ..........

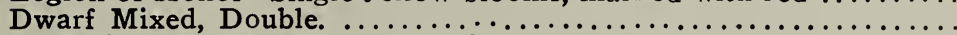

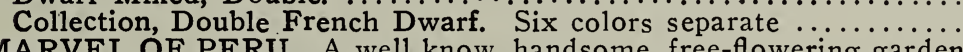

MARVEL OF PERU. A well know, handsome, free-flowering garden favorite does well everywhere. Mixed. (Four O'Clocks) .........

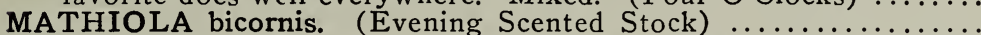

MATRICARIA. (Feverfew). Low-growing plants; suitable for beds

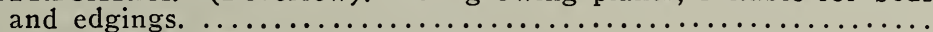

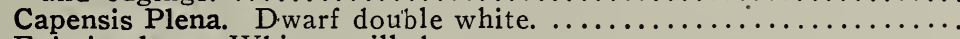

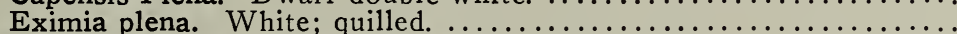

MAURANDYA. Mixed Colors. Tender climber $\ldots \ldots \ldots \ldots \ldots \ldots \ldots$

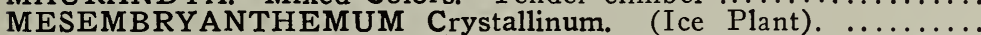

MIGNONETTE, Large-Flowering. The popular fragant garden annual. The seed can be sown at any time and, if successive sowings are made, its fragant, modest colored flowers may be

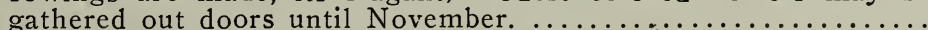

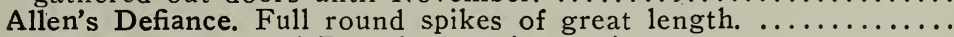

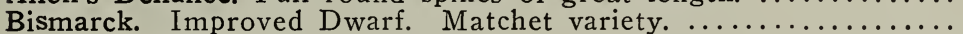

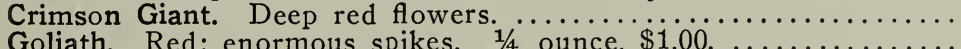

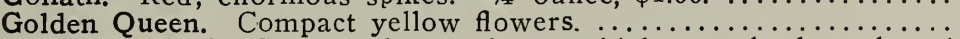

Machet, Dwarf. Strong plants of pyramidal growth; long broad

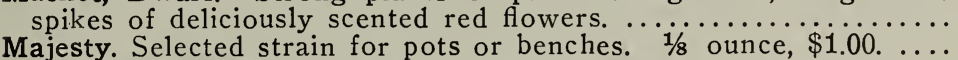

New York Market. The finest of all the fancy varieties of Mignonette for winter forcing. Seed saved from selected spikes under

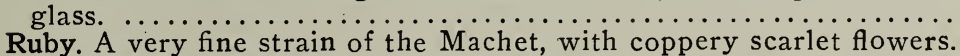

Sweet-Scented. (Reseda Odorata Grandiflora). The large-flowering garden variety.

MIMOSA pudica. (Sensitive Plant.) The leaves close when touched

MIMULUS trigrinus, spotted, mixed. (Monkey Flowers). .........

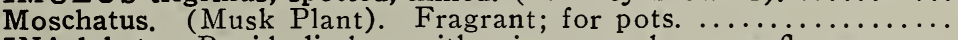

MINA lobata. Rapid climber, with crimson and orange flowers. ....

MOMORDICA. Trailing plants, with curious and ornamental foliage and remarkable fruit.

Balsamina. (Balsam Apple). Orange fruit. .............. 15

Charantia. (Balsam Pear). Copper colored scarlet fruit. ......... 15

MOON FLOWERS. (See Ipomoea Grandiflora).

MORNING GLORIES. (See Ipomoea and Convolvulus).

MUSA ensete. (Abyssinian Banana). A subtropical foliage plant..... MUSK. (See Mimulus).

MYOSOTIS, or Forget-Me-Nots. Perennials and hardy if given slight protection through the winter. Seed may be sown any time from spring till mid-summer.

Alpestris, Blue.

Alpestris, Mixed Colors. White, blue, pink, etc. $\ldots \ldots \ldots \ldots \ldots \ldots \ldots$

Dissitiflora. Blooms very early; flowers blue. $1 / 4$ ounce, 75 cts. . .
H. A. .50

H. P. $\quad .75$

H. A. .20

H. P. .35

H. P.

.05

.... 2.00

H. A. $\quad .25$

.10

.10

10

.05

.05

10

.05

2 H. A.

... . .50 .05

$\ldots \ldots . .50 \quad .05$

$\ldots . .50 \quad .05$

$\ldots \ldots . .25$

1 H. A. 50

$\begin{array}{lll}3 / 4 & \ldots \ldots \ldots & .50 \\ & & .50\end{array}$

$1 \ldots \ldots \ldots .40$

.05

.05

.05

.......

.25

2 H. A. .20

.05

H. H. A. .30

.05

H.H.P. . .

$11.5 \%$.50

$.0 \dot{0}$

$\begin{array}{lll}\ldots . . . & .50 \quad .05\end{array}$

H.H.P.

.10

H. H. A. .50

.05

H. A.

$\begin{array}{llrr}\because 1 / 2 & \ldots \ldots & .75 & .10 \\ 1 & \ldots \ldots & 1.00 & .10 \\ .1 & \ldots \ldots & 2.50 & .05 \\ 1 & \ldots \ldots & .00 & .10 \\ & & .50 & .05 \\ 3 / 4 & \ldots \ldots & .75 & .10 \\ 11 / 2 & \ldots \ldots & . . & .50\end{array}$

H. H. A. .50

H. A. 2.00

.10

H. H.A. . .. . .05

H. A. C. . .. 10

H.A. C. .50

.05

..... .50

.05

G. P.

.25

\begin{tabular}{|c|c|c|}
\hline $1 / 2$ & H. P. & .60 \\
\hline & $\ldots$ & . . \\
\hline
\end{tabular}

$\ldots \ldots . \quad .40 \quad .05$ 


\section{NAME AND DESCRIPTION.}

MYOSOTIS. (Continued).

Height

Palustris, Large-flowering. Dark blue. $1 / 4$ ounce, 60 cts

Palustris Semperflorens. An ever-blooming variety. Large, clear blue flowers. $1 / 4$ ounce, 60 cents.

Robusta grandiflora. Eliza Fonrobert. A very strong-growing variety.

Ruth Fischer. Compact growth; blue flowers.

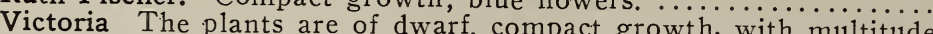
of bright blue flowers in dense umbels... growth, with multitude

MYOSOTIDIUM nobile. (New Zealand Forget-Me-Not). Azure

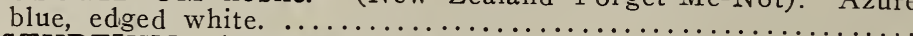

NASTURTIUM. (Tropaeolum nanum).

Tom Thumb, or Dwarf Varieties. These have a compact habit and attractive foliage; are not disturbed by insects; bloom in two months from sowing, and most profusely the whole season. ......

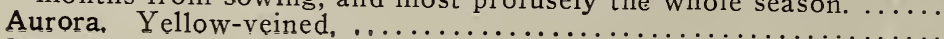

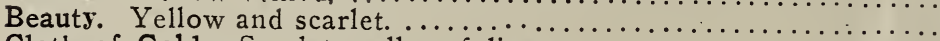

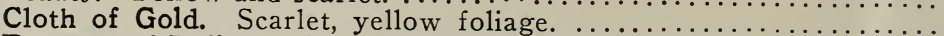

Empress of India. 'Crimson, dark foliage. . . . . . . . . . . . . . . .

King Theodore. Garnet; dark foliage. . . . . . . . . . . . . . . . .

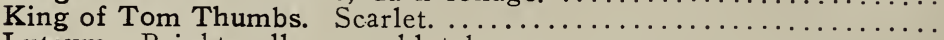

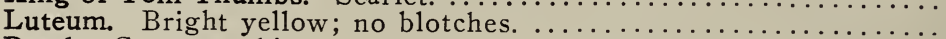

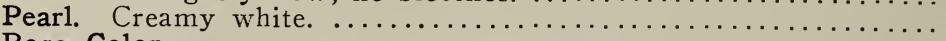

Rose Color.

Marshall's Dwarf Mixture. These contain all the leading named sorts, mixed. $1 / 4$ lb., 30 cents; 1b., $\$ 1.00$.

Collections of 12 Varieties.

Tall or Climbing Varieties. (Tropaeolum majus). Adapted for rockwork, banks, covering trellises or rustic work; the seeds, if picked

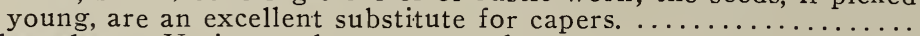

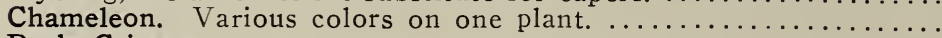

Dark Crimson.

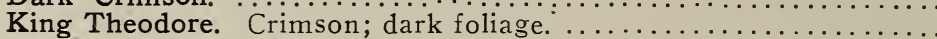

Pearl. Creamy white.

Rose. (von Moltke).

Scarlet.

Yellow.

Vesuvius. Salmon rose.

Marshall's Mixed, Climbing Varieties, from the best varieties. $1 / 4$ lb., 30 cents; 1 b., $\$ 1.00$

Collection of 12 Varieties

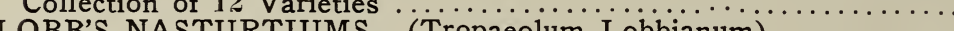

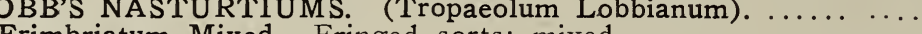

Frimbriatum Mixed. Fringed sorts; mixed.

Finest Mixture.

Madame Gunther Hybrids. A French strain; noted for wide range

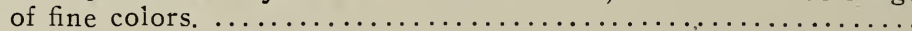

NEMESIA, Strumosa grandiflora Suttonii. Bushy plants; flowers of unique form.

NEMOPHILA, mixed colors.

NICOTIANA affinis. Fragrant, star-shaped white flowers. $\ldots \ldots \ldots \ldots$

Affinis Hybrids. Large-flowered; scented. All shades; mixed.....

Sanderae Hybrids. All Colors.

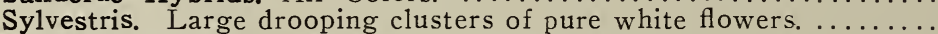

NIEREMBERGIA Frutescens. For hanging baskets or borders; large, cup-shaped lilac flowers.

NIGELLA. (Love-in-a-Mist). Beautiful border plants.

Miss Jekyll. A lovely variety with cornflower-blue blossoms; splendid for cutting.

Miss Jekyll White. Valuable for borders and cutting ............

Finest Mixed. Blue, white and purple.

OENOTHERA. (Evening Primrose). Finest mixed.

PANSIES are the most popular flowers grown. They thrive best in a cool, moist, but well-drained soil.

Marshall's Matchless Mixture. This matchless strain consist entirely of the newest best-shaped and most handsome flowers, including an imnense variety of brilliant colors. The seeds we offer are carefully saved from the largest selected flowers. $1 / 8$ ounce, $\$ 1.25$.

Superb Giant, mixed. A rich and most choicely varied mixture. Producing only the finest colors, largest flowers and beautiful forms. finest mixed.

German, finest mixed
Good Mixed Pansies.

Princess. An erect-growing variety. Fine for cutting. Various colors.

\section{1}

Duration Ounce

Per

$\$ 0.10$

$\begin{array}{cccc}3 / 4 & \ldots \ldots . & \$ 2.00 & .10 \\ 1 & \ldots \ldots . & 1.00 & .10 \\ 3 / 4 & \ldots \ldots . & \ldots . & .25 \\ 1 / 2 & \ldots \ldots & 1.50 & .15 \\ & \text { H. P. } & \ldots & .25\end{array}$

H. A.

H. A.

.15 .05

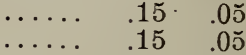

$\begin{array}{lll}\ldots \ldots & .15 & .05 \\ \ldots \ldots & .15 & .05\end{array}$

$\ldots \ldots . \quad .15 \quad .05$

$\ldots \ldots . .15$. .05

$\begin{array}{lll}\ldots \ldots & .15 \\ \ldots \ldots & .05 \\ \ldots & .15\end{array}$

$\begin{array}{lll}\ldots \ldots & .15 \\ \ldots . & .05\end{array}$

$\ldots \ldots .15 \quad .05$

$\ldots \ldots . \quad .10 \quad .05$

$\ldots \ldots . .50$

6 H. A. C.

... .1. .J5

$\begin{array}{lll}\ldots \ldots & .15 & .05 \\ \ldots & .15 & .05\end{array}$

$\ldots \ldots . .15 \quad .05$

.... .15 .05

$\begin{array}{ll}\ldots . . & .15 \\ .05\end{array}$

$\ldots \ldots .15$

$\ldots \ldots .15$

.... 15

.05

$.10 \quad .05$

$\ddot{\mathrm{H}} \ddot{\mathrm{A}} \mathrm{C} \quad . .50$

H. A.

$.20 \quad .05$

$.20 \quad .05$

.15

.05

$3 / 4$ H. A.

.10

H. A. $.40 \quad .05$

H. H. A. $.40 \quad .05$

$\begin{array}{lll}\ldots \ldots & 1.00 \quad .10\end{array}$

$\ldots \ldots .60 \quad .10$

.... .50 .10

H. H. P. .50 .10

H. A.

$11 / 2$
$11 / 2$
$11 / 2$

1

$\begin{array}{lrr}\ldots \ldots & .50 & .10 \\ \ldots \ldots & 2.00 & .10 \\ \text { H. A. } & .25 & .05 \\ & .25 & .05\end{array}$

$1 / 2$. H. H. P. 
GIANT PANSIES, in Varieties.

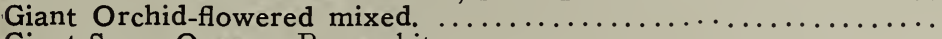

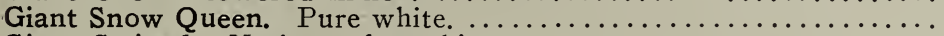

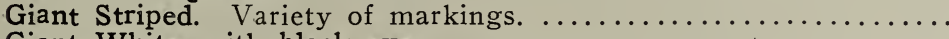

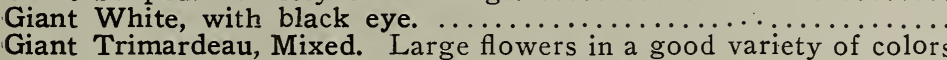

Giant Trimardeau, Mixed. Large flowers in a good variety of colors Collection of 12 Varieties Giant Trimardeau.

PAPAVER. (See Poppies).

PASSION FLOWER, coerulea. Large; violet and blue. ...........

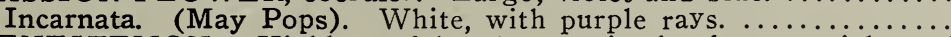

PENTSTEMON. Highly useful and attractive hardy perennials, and much used in the hardy border. Gentianoides Fine Mixed Colors. $\ldots \ldots \ldots \ldots \ldots \ldots \ldots \ldots \ldots \ldots \ldots \ldots \ldots$ mixture of the ${ }_{\text {Mest }}$

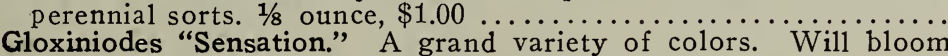

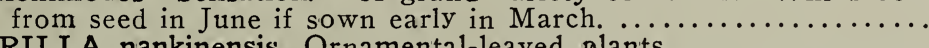

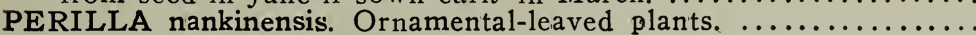

PETUNIA. One of our easiest cultivated and freest-flowering annuals Will succeed almost anywhere and give a continuity of the most

brilliant bloom from June till killed by the frost. ................ fine strain, remarkable for the large, beautiful, colored, double flowers.

SINGLE VARIETIES.

Marshall's Superb Large-Flowered Mixed. (California Giants). Mag-

nificent flowers, with throats, beautifully veined. …........... fringed and frilled ediges; distinct and beautiful.

Large-Flowered, Finest Mixed. Fine large flowers in superb mixture

Fine Mixed. An assortment of medium-sized flowers; fine for bedding.

Maculata. Striped and Blotched. (Inimitable). Flowers quite large

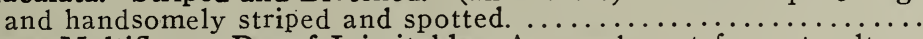

Nana Multiflora. Dwarf Inimitable. A superb sort for pot culture.

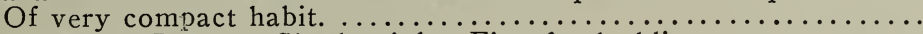

Bar Harbor Beauty. Single pink. Fine for bedding. . . . . . . . . .

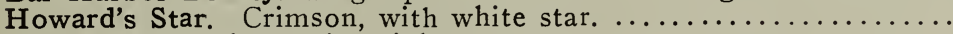

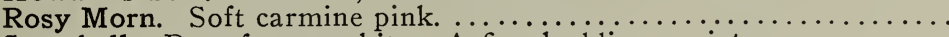

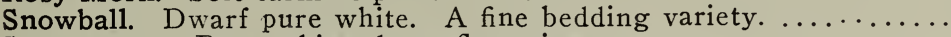

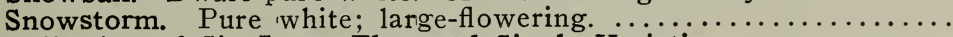

Collection of Six Large-Flowered Single Varieties. .............

PHLOX, Drummondi Grandiflora. Improved large-flowering strains

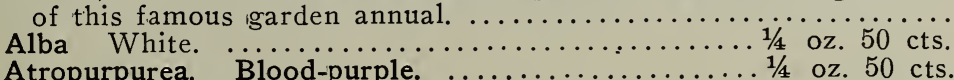

Atropurpurea. Blood-purple. $\ldots \ldots \ldots \ldots \ldots \ldots \ldots \ldots \ldots \ldots \ldots \ldots \ldots \ldots \ldots \ldots \ldots \ldots$
Atrorosea. Brilliant deep rose. $\ldots \ldots \ldots \ldots \ldots \ldots$

Chamoise-rose. Salmon-pink; orange eye..........

Cocinea. Brilliant scarlet. ...................

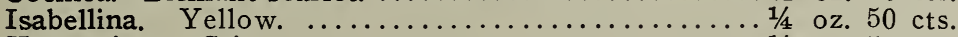

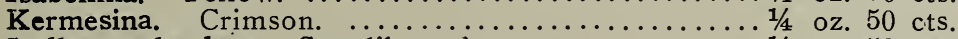

Stellata splendens. Star-like crimson ............

Choicest Mixed. Contains a vey large variety of color $1 / 4$ oz. $25 \mathrm{cts}$.

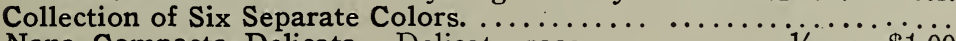

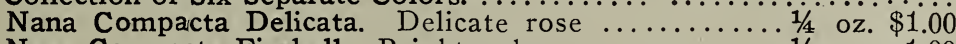

Nana Compacta Fireball. Bright red. ............ 1/4 oz. 1.00

Nana Compacta Snowball. Compact, pure white ...... 1/4 oz. 1.00

Nana Compacta Mixed Colors. Star-shaped flowers. .. 1/4 oz. 1.00

PHLOX. Hardy Perennial, Decussata. Most brilliant colored flowers

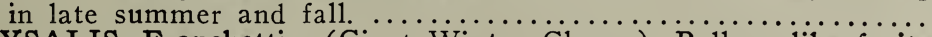

PHYSALIS, Franchett. (Giant Winter Cherry). Balloon-like fruits

PHYSOSTEGIA (False Dragon Head).

Virginica. One of the prettiest hardy perennials. It forms dense bushes bearing freely spikes of delicate pink tubular flowers.....

Virginica Alba. Pure white, and a pretty companion to the pink

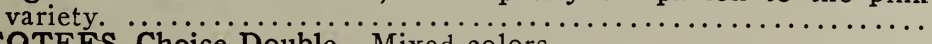

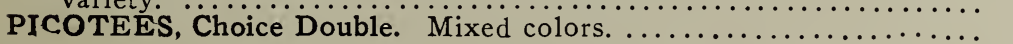

\begin{tabular}{|c|c|c|c|}
\hline - & $\ldots \ldots \$$ & $\$ 2.50$ & $\$ 0.10$ \\
\hline . . & $\ldots \ldots$ & 2.00 & .10 \\
\hline & $\ldots \ldots$ & 2.50 & .10 \\
\hline & $\ldots \ldots$ & 2.00 & .10 \\
\hline & $\ldots \ldots$ & 2.00 & .10 \\
\hline & $\ldots \ldots$ & $2.09)$ & .10 \\
\hline & $\ldots \ldots$ & 2.00 & .10 \\
\hline & ...... & 2.00 & .10 \\
\hline & ...... & 2.00 & .10 \\
\hline & $\cdots \cdots$ & 2.50 & .10 \\
\hline & $\cdots \cdots$ & 2.00 & .10 \\
\hline & $\cdots \cdots$ & - $\cdots$ & .00 \\
\hline & (5) & & \\
\hline & H. H. P. & & .10 \\
\hline & $\cdots \cdots$ & $\cdots$ & .10 \\
\hline 2 & H. P. & 2.00 & .10 \\
\hline & H. P. & - . & .25 \\
\hline $\begin{array}{l}2 \\
11 / 2\end{array}$ & $\begin{array}{l}\text { H. P. } \\
\text { H. A. }\end{array}$ & $\ddot{2}$ & .10 \\
\hline & & & .0 \\
\hline
\end{tabular}

H. A.

$\ldots \ldots$

1 H. A.

H. A. ... 10




\section{NAME AND DESCRIPTION.}

PINKS. (See Dianthus).

\section{PLATYCODON Grandiflora. The large-flowering Chinese Bell}

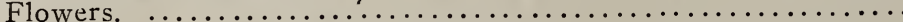

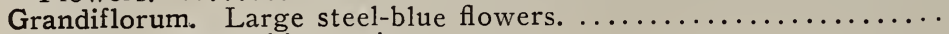

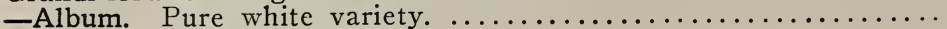

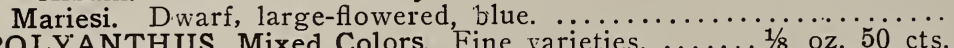
POLYANTHUS, Mixed Colors. Fine varieties. ....... 1/8 oz. 50 cts.
PORTULACA. One of the freest-flowering dwarf annuals, especially adapted for sunny locations. Flowers of the most brilliant colors.

Single. Separate colors, Rose, Scarlet, White, Yellow.

Single. Finest Mixed.

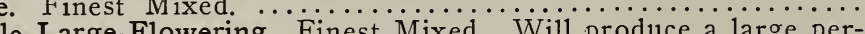
centa of double flowers in many colors. ......... 1/4 oz. $\$ 1.00$ POPPIES. Showy, free-blooming, old-fashioned flowers. Very effective

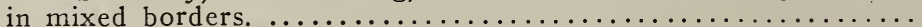

Single Annual Varieties:

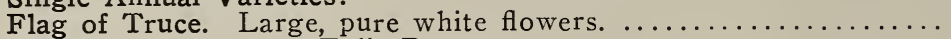

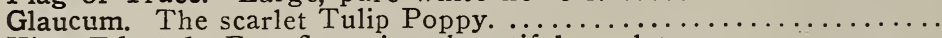

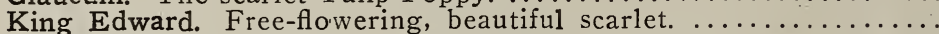

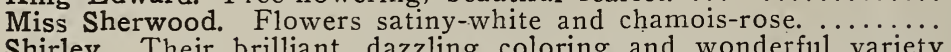

Shirley. Their brilliant, dazzling coloring and wonderful variety
make a very effective display in the garden or for cut flowers.

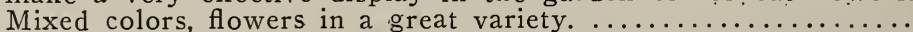

The Bride. A beautiful variety with large pure white flowers. ......

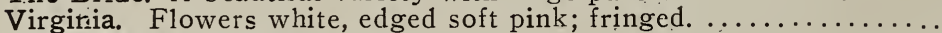

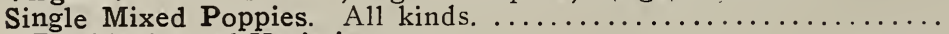
Double Annual Varieties:

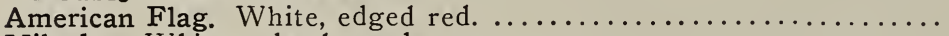

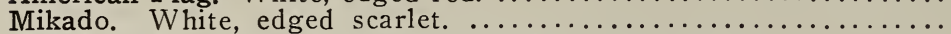

White Swan. Large beautifully fringed white flowers. . . . . . . . . . .

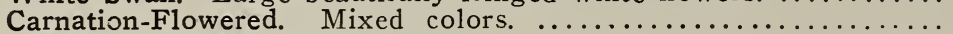

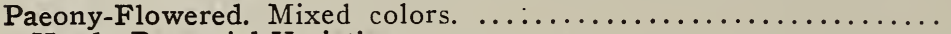
Hardy Perennial Varieties:

Bracteatum. Orange-scarlet hardy poppy. .........................

Iceland Poppies. While these are hardy perennials, they flower the
first year from seed, blooming almost as quickly as the annual sorts

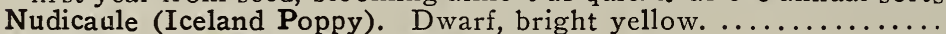

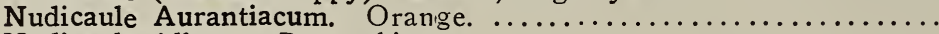

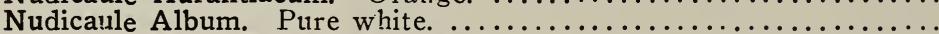

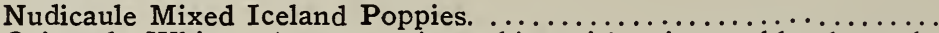

Orientale White. A pure satiny white with crimson blotch at the

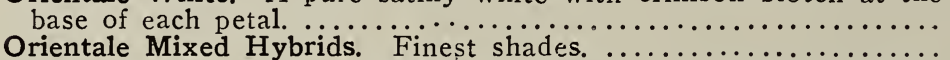

PRIMULA SINENSIS (Chinese Primrose). A charming profuseflowering plant, indispensable for winter and spring decoration...

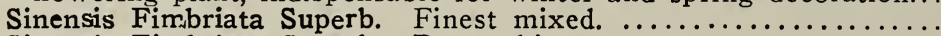

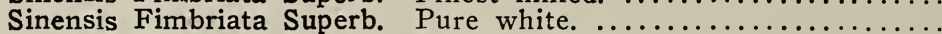

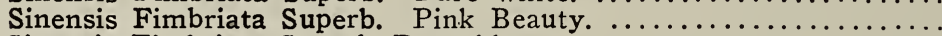

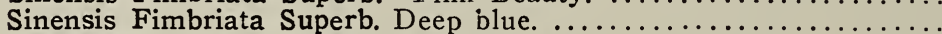

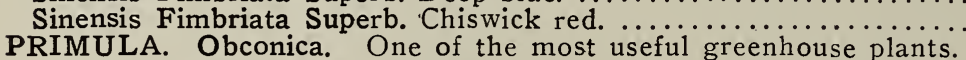

Obconica Gigantea. Alba, white. . . . . . . . . . . . . . . . . . .

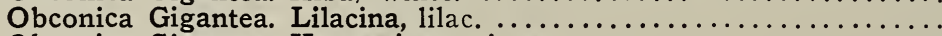

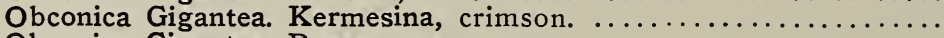

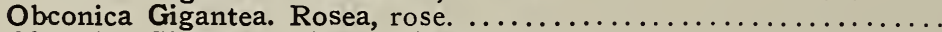

Obconica Gigantea. Finest mixed. $\ldots \ldots \ldots \ldots \ldots \ldots \ldots \ldots \ldots \ldots \ldots \ldots \ldots \ldots \ldots \ldots \ldots \ldots \ldots \ldots$
PRIMULA. Malacoides. A charming free-flowering pot plant; delicate lilac.

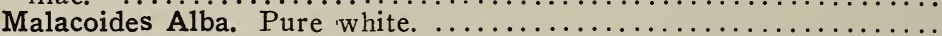

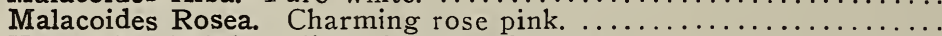

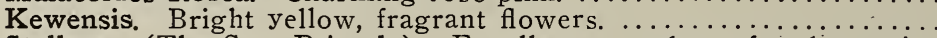

Stellata. (The Star Primula). Excellent pot plants for decoration

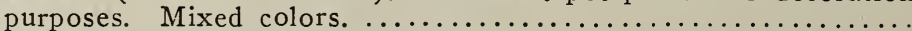

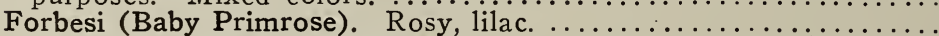
Hardy Primulas or Primroses:

Japonica (Japanese Primrose). Mixed colors. ......... 1/4 oz. $\$ 1.00$.

Vulgaris. English yellow primrose. ............ oz. 75 cts.

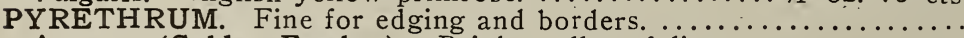

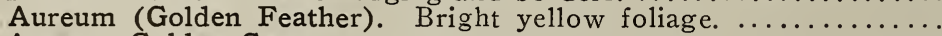

Aureum Golden Gem.

Hybridum. Single, large-flowering. Mixed colors: .... M $_{4}$ oz. $\$ 1.00$

Hybridium fl. pl. Double, large-flowering; beátififul colors. .......

\begin{tabular}{|c|c|c|c|}
\hline & $\begin{array}{c}\text { Н. Р. } \\
\ldots \ldots \text {. }\end{array}$ & $\$ 1.00$ & $\$ 0.10$ \\
\hline & $\ldots$ & 1.00 & .10 \\
\hline & & 1.00 & .10 \\
\hline $1 / 2$ & H. P. & . . & .10 \\
\hline $1 / 2$ & H. A. & & \\
\hline & $\cdots$ & .00 & .05 \\
\hline $1 / 2$ & $\ldots$ & 3.00 & .10 \\
\hline
\end{tabular}

H. A.

$1 \quad \cdots \cdots$

$\cdots \ldots$

$\ldots \ldots$

$\cdots \cdots$

H. A.

H. P.

H. P.

G. P.

$\ldots \ldots$

$\ldots \ldots$

$\ldots \ldots$

G. $P$.

H. H. P.. . .

H. P.

H. P.

H. H. P.

2.00

.10 
Height

REHMANNIA Angulata. Flowers rose-purple with spotted throat.. RHODAN'THE (Everiasting or Straw Flower). Mixed colors. ... RICINUS (Castor Oil Plant). From seed they quickly attain gigantic proportions, and are ornamental till destroyed by frost.

Borboniensis. Immense violet foliage.

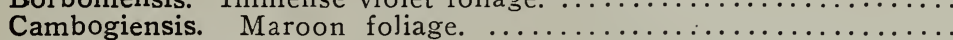

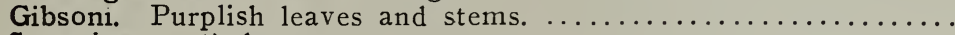

Sanguineus. Red stems.

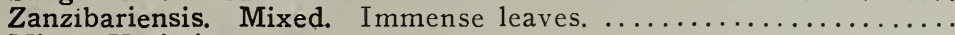

Mixed Varieties.

ROCKET, Sweet. $\AA$ very interesting, useful and free-flowering plant.

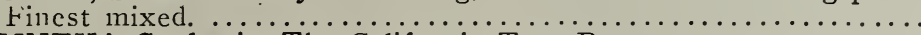

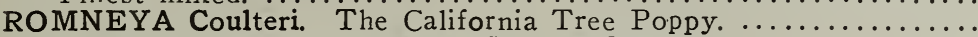

RUDBECKIA Bicolor Superba. Yellow flowers.

Neumanni. Bright orange with black cone.

Purpurea Hybrida Grandiflora. Beautiful large-flowered hybrids...

SALPIGLOSIS. One of the prettiest annuals of easy culture; ivery

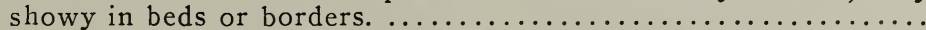

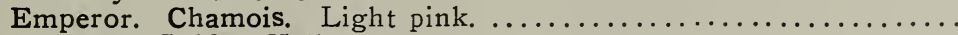

Emperor. Golden Yellow.

Emperor. Light Blue with Gold.

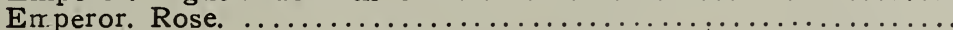

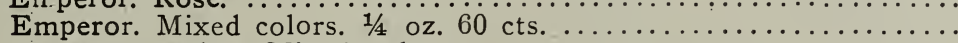

Large-Flowering. Mixed colors.

Large-Flowering. Colletcion of Six separate colors.

SALVIA (Flowering Sage) One of our most handsome summer- and autumn-flowering plants, growing into compact bushes about 3 feet

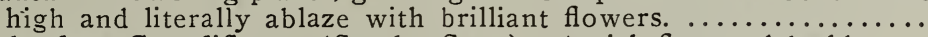

Splendens Grandiflora. (Scarlet Sage). A rich-flowered bedder. .

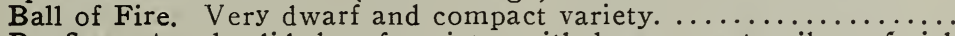

Bonfire. A splendid dwarf variety, with large, erect spikes of rich scarlet flowers. ......................1/16 oz. 50 cts.

Ostrich Plume The plants are well covered with brilliant-scarlet

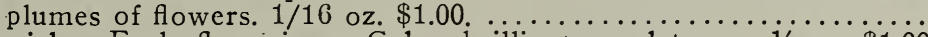

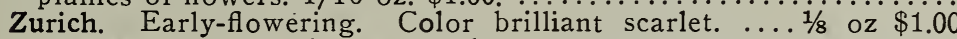

Farinacea. A perennial variety, but best grown as an annual. Seed sown in the open ground in May blooming from July to frost. The

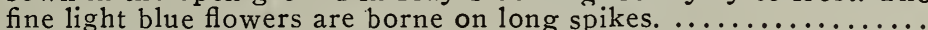

Patens. Magnificent blue flowers.

SAPONARIA Calabrica. Dwarf annual with pink starry flowers.

SCABIOSA, or Mourning Bride. Very showy, free-flowering annual.

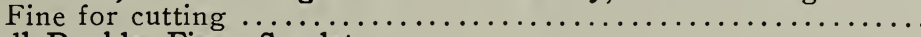

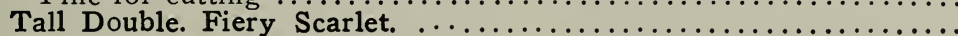

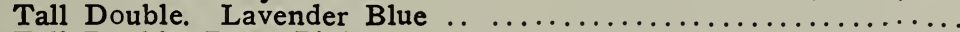

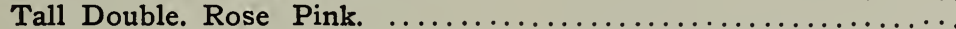

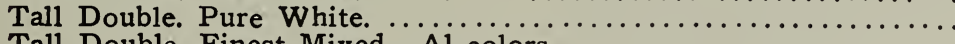

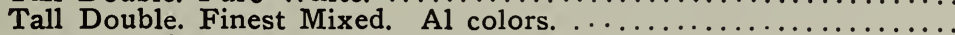

Dwarf Double. Many colors mixed . . . . . . . . . . . . . . . .

Collection of Tall Scabiosa. Six colors.

Caucasia Hybrida Mixed. Hardy perennial with large flowers. .....

SCHIZANTHUS. Popularly known as the Poor Men's Orchid, for its

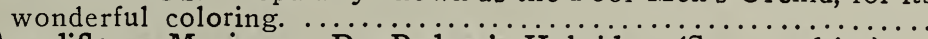

Grandiflorus Maximus. Dr. Badger's Hybrids. (Se novelties).

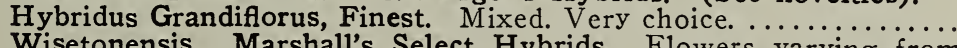

Wisetonensis. Marshall's Select Hybrids. Flowers varying from white with yellow eye, to rose with bronze center. Fine for pots.

Wisetonensis Compacta. Mixed. Beautiful and varied colors. .....

SEDUM Coeruleum (Blue Stonecrop). For rockwork or edgings....

SENECIO. (See Jacobaea).

SENSITIVE PLANT. (See Mimosa pudica).

SILENE compacta. Double. Mixed colors.

SMIIAX (M rysiphyllum a.

SNAPDRAGON. (See Antirrhinum).

SOLANUM, Capsicastrum nanum. Jerusalem Cherry. ...........

Fra Diavolo. Compact well-branched plants with many scarlet fruits.

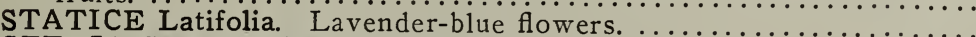

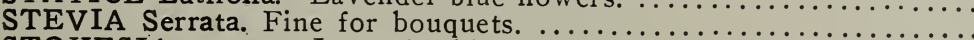

STOKESIA cyanea. Lavender-blue flowers $\ldots \ldots \ldots \ldots \ldots \ldots \ldots \ldots \ldots \ldots \ldots$

Cyanea alba. A pure white-flowering form. ..........

Finest Mixed. A mixture of pink, purple, blue and white shades. feet

Duration Ounce Per

H. H. P.... $\$ 0.25$

H. A. $\$ 0.7 \dot{7} \quad .05$

H. H. A. .20

..... .25

$\ldots . .25$

..... . 20

$\ldots \ldots .25$

..... .15

.05

.05

.05

.05

.05

H. P. .20

H. H. P. . .

H. A.

H. P.

H. P.

H. A.

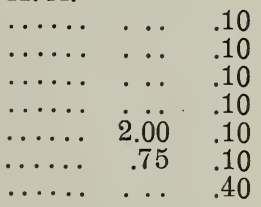

H. A.

$\begin{array}{lll}3 & \text {...... } & 1.50\end{array}$

$11 / 2 \quad \ldots \ldots .4 .00$

.05

2

3.00

.10

2

$\ldots$

6.00

H. H. P.. .

H. A.

..... 1.00

..... 1.00

$\ldots . .1 .00$

$\ldots \ldots 1.00$

$\ldots . . .50$

.... 40

$\because \cdots, \quad . . \quad .30$

$\ddot{2}$

H. P.

. .

.10

H. $\dot{\mathrm{H}}$. A.

H. $\dddot{H}$. A..$\dot{5} \dot{0}$

........

H. $\mathrm{A}$

H. A.

T. $\mathrm{P}$.

$\ddot{\mathrm{H}} . \ddot{\mathrm{P}}$

T. P.

H. P.

i. 00 
STOCKS. Fine for garden decoration; flowers double; or various colors and ivery fragrant.

Marshall's Giant Perfection Ten-Week. A splendid double-flowered strain; especially adapted for bedding or pot culture. ...........

Giant Perfection, Chamois Rose ..............1/8 oz. 75 cts.

Giant Perfection, Dark blue. .....................

Giant Perfection, Crimson. ..................

Giant Perfection. Flesh Color. ............... 1/8 oz. $75 \mathrm{cts}$.

Giant Perfection, Light Blue. ............. 1/8 oz. $75 \mathrm{cts}$.

Giant Perfection, Pure White. ............... oz. 75 . cts.

Giant Perfection, Rose. .................. 1/8 oz. 75 cts.

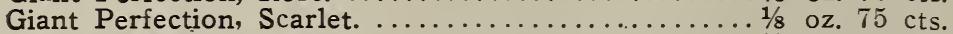

Giant Perfection, Yellow. ................ oz. 75 cts.

Giant Perfection, Finest Mixed. Ail colors .......... $1 / 4$ oz. $\$ 1.00$

Large-Flowering. 10 weeks. Mixed colors. ....... $1 / 4$ oz. 75 cts.

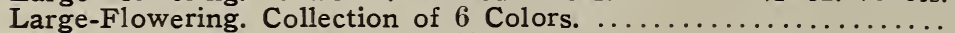

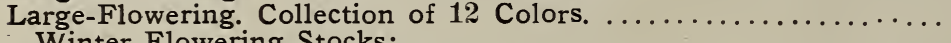
Winter Flowering Stocks:

Cut and Come Again, Princess Alice. Double white. . 1/8 oz. $\$ 1.00$

Beauty of Nice. Splendid rose color............ $1 / 8$ oz. 1.00

Crimson King. Brilliant fiery crimson. ...........

Empress Elizabeth. Carmine rose. ..............

Empress Augusta Victoria. Silvery lilac. ........... $1 / 8$ oz. 1.00

Giant abundance. Carmine-rose................. oz. 1.00

Queen Alexandra. Delicate rosy lilac.............. 1/8 oz. 1.00

White Lady. Large double snow white............... $1 / 8$ oz. 2.00

Yellow. Monte Carlo. Clear yellow.............1/8 oz. $75 \mathrm{cts}$.

East Lothian, Fine for fall and winter flowering.

East Lothian, Crimson. .................... oz. $\$ 1.50$

East Lothian, Brilliant Rose. ...................... oz. 1.00

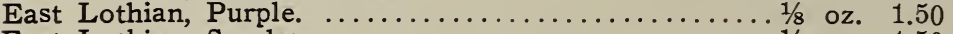

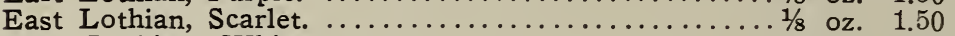

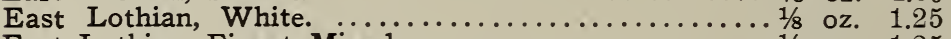

East Lothian, Finest Mixed. ................... oz. 1.25

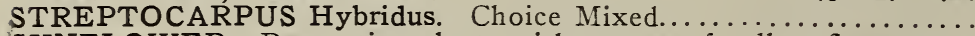

SUNFLOWER. Decorative plants with masses of yellow flowers....

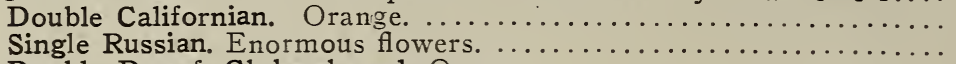

Double Dwarf. Globe-shaped. Orange.

Red Hybrids. "The Red Sunflower". Large flowers in various shades

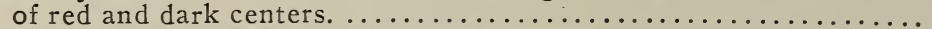

Cucumerifolius. (Miniature Sunflower). Of pyramidal growth; cov-

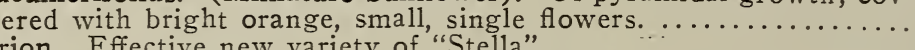

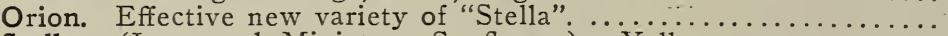

Stella. (Improved Miniature Sunflower). Yellow. $\ldots \ldots \ldots \ldots \ldots \ldots$

Perennis Hybrids. Mixed hardy varieties.

\section{SWEET PEAS. WINTER VARIETIES.}

H. A.

\begin{tabular}{|c|c|c|c|}
\hline & $\cdots \cdots$ & $\$ 4.00$ & $\$ 0.15$ \\
\hline & $\ldots$. & 4.00 & .15 \\
\hline & $\ldots \ldots$ & 4.00 & .10 \\
\hline & $\cdots \cdots$ & 4.00 & .15 \\
\hline & $\cdots \cdots$ & 4.00 & .15 \\
\hline & $\cdots \cdots$ & 4.00 & .15 \\
\hline & $\cdots \cdots$ & 4.00 & .15 \\
\hline & $\cdots \cdots$ & 4.00 & .10 \\
\hline & $\cdots \cdots$ & $\begin{array}{l}4.00 \\
3.50\end{array}$ & .15 \\
\hline & $\cdots \cdots$ & 3.00 & .10 \\
\hline & $\ldots \ldots$ & & .05 \\
\hline & ..... & $\cdots$ & .30 \\
\hline 2 & & $\cdots$ & .50 \\
\hline 2 & ..... & 5.00 & .25 \\
\hline & $\cdots \cdots$ & 5.00 & .25 \\
\hline & $\cdots \cdots$ & 5.00 & .25 \\
\hline & …. & 6.00 & .25 \\
\hline & …. & 0.00 & .25 \\
\hline & $\cdots \cdots$ & 6.00 & .25 \\
\hline & $\ldots \ldots$ & & .25 \\
\hline & $\ldots \ldots$ & 4.00 & .25 \\
\hline • & $\cdots \ldots$ & . & .25 \\
\hline$\cdots$ & $\cdots \cdots$ & $\cdots$ & .25 \\
\hline 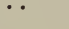 & ..... & $\cdots$ & .25 \\
\hline 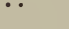 & $\cdots \cdots$ & $\cdots$ & .25 \\
\hline & $\because \cdots \cdots$ & $\cdot \cdots$ & .25 \\
\hline $1 / 2$ & $\ddot{\mathrm{G}} . \ddot{\mathrm{P}}$ & $\begin{array}{ll}\cdots \\
. & \cdots\end{array}$ & .50 \\
\hline & H. A. & & \\
\hline 7 & $\cdots \cdots$ & .20 & D. \\
\hline & & & \\
\hline & ..... & $\cdots$ & .10 \\
\hline 3 & $\cdots \ldots$ & .40 & .05 \\
\hline 5 & ..... & .50 & .10 \\
\hline & ..... & .50 & .10 \\
\hline 3 & H. P. & $\begin{array}{c}.00 \\
. .\end{array}$ & .10 \\
\hline
\end{tabular}

These are the best varieties for growing under glass.

ORCHID FLOWERING.

Lavender Orchid. Very large lavender pink flowers.

Mrs. A. A. Skach. A beautiful bright pink self. .......

Mrs. M. Spanolin. The purest white; black seeded $\ldots \ldots \ldots \ldots \ldots \ldots \ldots$

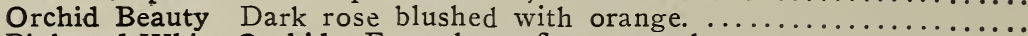

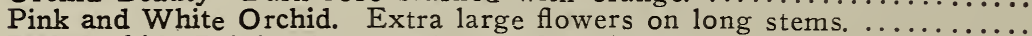

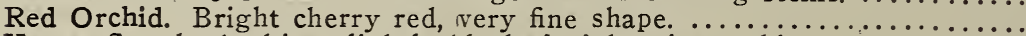

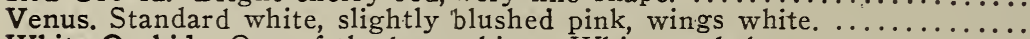

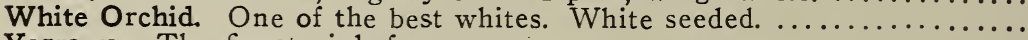

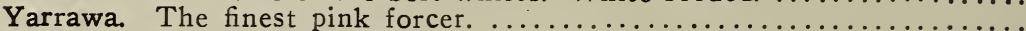

GRANDIFLORA VARIETIES.

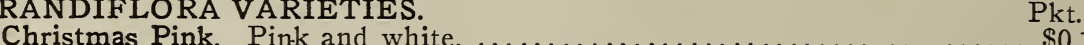

Christmas White. A companion to Christmas Pink. $\ldots \ldots \ldots \ldots \ldots \ldots \ldots \ldots$

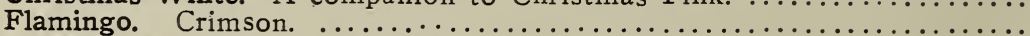

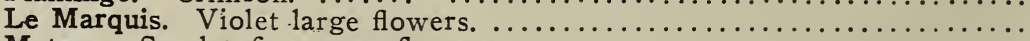

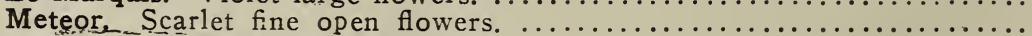

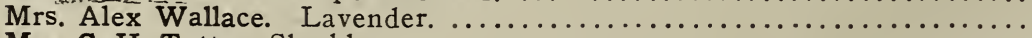

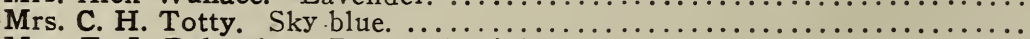

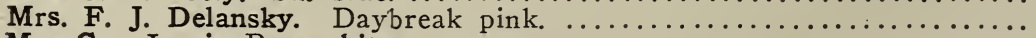

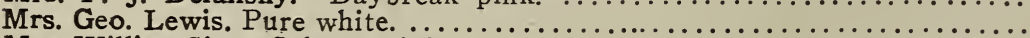

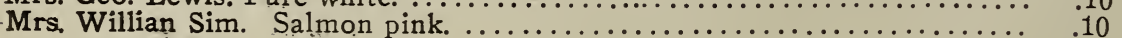

$\begin{array}{lrr}\text { Pkt. } & 1 / 4 & \text { Ounce } \\ & \$ 0.25 & \$ 1.00 \\ & .25 & 1.00 \\ & .25 & 1.00 \\ & .25 & 1.00 \\ & .25 & 1.00 \\ & .25 & 1.00 \\ & .25 & 1.00 \\ & .25 & 1.00 \\ & .25 & 1.50 \\ \text { t. } & \text { Oz. } & 1 / 4 \\ .10 & \$ 0.25 & \$ 0.75 \\ .10 & .25 & .75 \\ .10 & .25 & .75 \\ .10 & .25 & .75 \\ .10 & .25 & .75 \\ .10 & .30 & 1.00 \\ .10 & .25 & .75 \\ .10 & .25 & .75 \\ .10 & .25 & .75 \\ .10 & .25 & .75\end{array}$




\section{S W E E T P E A S}

There are no Annual Climbers that are more popular or more admired by everybody than Sweet Peas. They are of the easiest culture, unrivalled for cutting, delightfully fragrant and of the brightest and daintiest colors imaginable. As soon as the ground can be worked in the Sp:ing, sow the seed in trenches at least 6 inches in depth, then as the plants grow fill in the soil about one inch at a time until the trenches are full, taking care not to cover the young plants. Liquid manure applied occasionally will be found very beneficial. Pick the flowers frequently, for if allowed to form seed the plants will soon stop blooming.

\section{NEW SPENCER VARIETIES.}

The following include the best of the recent and 1916 novelties and are all well worthy of a trial for show or cutting purposes.

Edith Taylor. A distinct soft salmon-rose. Pkt. 25 cts.; oz. 75 cts. $1 / 4$ lb. $\$ 2.00$.

Fiery Cross. . The color is a fire-red or scarlet, without any shading. It does not scorch or burn in the hot sun and has beautifully waved and fluted flowers. Pkt. (10 seeds), 25 cts.

Hilary Christy. Standard Salmonorange edged with fiery orangescarlet; wings rosy salmon. A strong grower, with good size and form. Pkt. (20 seeds), 25 cts.

Illuminator. The warm salmonorange ground color of the flowers scintillates through the rich bright cerise-pink and illuminates the flower delightfully. Of vigorous growth and has long stout stems. Per Pkt. 25 cts. Oz. 75 cts. $1 / 4$ lb. $\$ 2.00$.

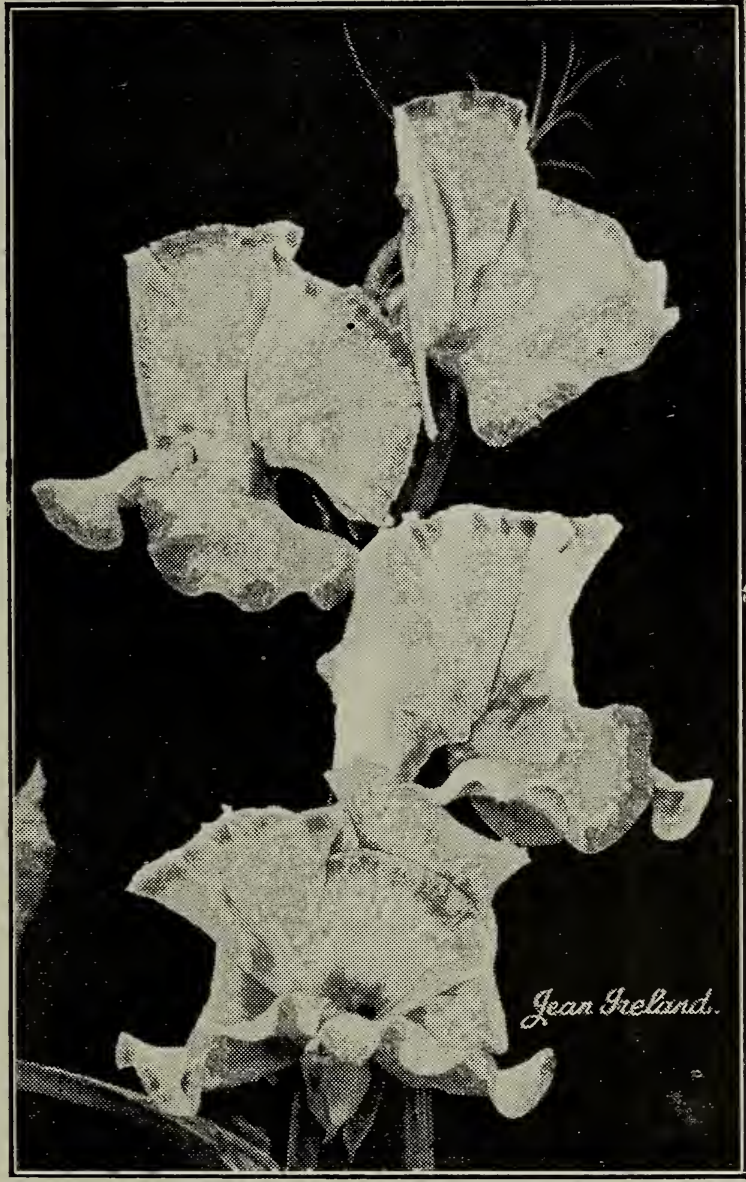

Sweet Pea. Jean Ireland.

Jean Ireland. Dobbie's The color is a creamy-buff, the fine broad standard and wings being beautifully edged and shaded with carmine-rose. A fine, free grower with four flowers to a stem. Pkt. (20 seeds), 50 cts..

King White. A perfect white Spencer standards of imense size, bold expanded form, and exquisitely waved. A large proportion of four-flowered sprays. Per Pkt. 25 cts.; oz., 75 cts. $1 / 4$ lb. $\$ 2.00$

Margaret Atlee. Pink on cream, suffused with salmon: The wings are large, wavy and well set. Pkt. 25 cts.; oz. 75 cts. $1 / 4$ 1b. $\$ 2.00$.

Margaret Madison. Delicate azure blue, slightly shaded mauve. Pkt. 25 cts.; oz. 75 cts. 1/4 $1 \mathrm{~b} \$ 2.00$.

The President. A glowing scarlet self. The flowers are of the largest size, carried on strong stiff stems, usually in fours, waved and well expanded. Pkt. (10 seeds), 25 cts.

Wedgewood. The best blue Spencer in a true self color, of finest Spencer form the standards and wings being well waved. Per pkt. 25 cts. oz. 75 cts. $1 / 4$ lb. $\$ 2.00$.

\section{CUPID OF DWARF SWEET PEAS.}

These grow about 9 inches high and are adapted for borders or beds. Finest Mixed Colors. Pkt. 10 cts. oz. 20 cts. $1 / 4$ lb. 50 cts.

FARMOGERM FOR SWEET PEAS.

Sweet Peas flower earlier longer and better treated with Farmogerm Small Size; 25 cts Garden size; 50 cts. 


\section{IMARSHALL'S SPENCER TYPE SWEET PEAS.}

The Spencer types of Sweet Peas are a great improvement over the Large Flowering varieties. For cutting and exhibition purposes they are indispensable. The following varieties are a selection of the many kinds of this class best adapted for general use.

America Bright scarlet-red flaked on white, of the Countess SpencerPer Pkt.

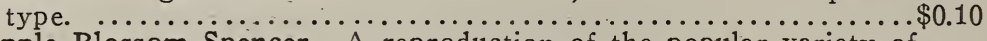

Apple Blossom Spencer. A reproduction of the popular variety of

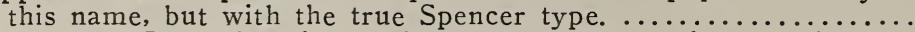

Asta Ohn. Lavender, tinted with mauve. Large and wavy wings. ... 10

Aurora Spencer. Very large flowers. Creamy-white, flaked and

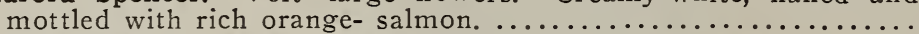

Blanche Ferry Spencer. Rose standard with white wings. ........... 10

Black Knight Spencer. Rich deep maroon $\ldots \ldots \ldots \ldots \ldots \ldots \ldots \ldots \ldots \ldots \ldots \ldots$
Captain of the Blues. Maroon purple, wings blue. 10

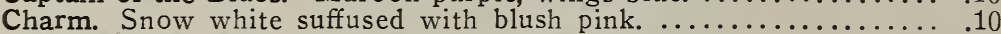

Countess Spencer. Soft rose pink; large wavy petals. ............ 10

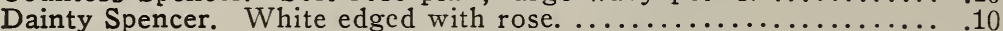

Decorator. Rich rose overlaid with terra-cotta, intensifying to deep

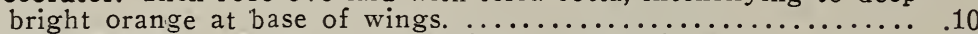

Elfrida Pearson. Blush pink deeping towards the edges. ........ .10

Evelyn Hemus. Very beautiful, cream edged pink. ...............

Florence Morse Spencer. Light pink, edged 'with darker pink. Very large, with long stems. .............................. 10

Flora Norton Spencer. Bright blue with a small tint of purple. .... 10

George Herbert. Bright rosy carmine. ................... 10

Hercules. Rich clear rose-pink. Larger than 'Countess Spencer. .... .10

Helen Lewis. A fine crimson-orange, wings orange-rose. $\ldots \ldots \ldots . .10$

John Ingram. Rich carmine-rose. ........................... 10

King Edward Spencer. Bright crimson-scarlet. .....................

Maud Holmes. A deep carmine scarlet color; of the true Spencer

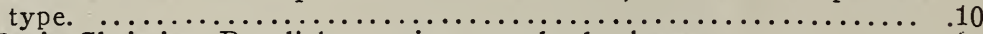

Menie Christie. Purplish carmine, standard wings rosy. $\ldots \ldots \ldots \ldots . .10$

Mrs. Cuthbertson. Standard rose-pink, wings nearly white........ .10

Mrs. Routzham Spencer. Apricot on buff, suffused with delicate pink. .10

Orchid. Rich deep lavender, slightly suffused pink on wings and

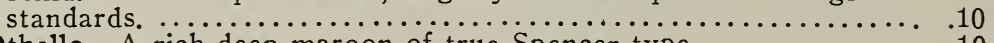

Othello. A rich deep maroon of true Spencer type. ............... 10

Picotee. Flowers 'white, beautifully edged carmine. ............... 10

Primrose Spencer. Primrose or creamy yellow. .................. 10

Queen. (Sutton's). Pink, on cream distinctly waved. ..............

Queen Alexandra. Spencer. Crimson scarlet. ................... 10

Royal Purple. A rich royal-purple. .......................... 10

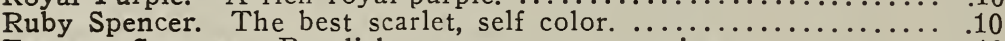

Tennant Spencer. Purplish-mauve, very attractive. ...............

White Spencer. A pure white with long, strong stems. $\ldots \ldots \ldots \ldots . .10$

Marshall's Matcheless Mixed Spencer Hybrids. ................. 10

Oz. $\quad 1 / 4 \mathrm{Lb} . \quad \mathrm{Lb}$.

$\$ 0.25 \quad \$ 0.75 \quad \$ 2.50$

$\begin{array}{llll}.10 & .25 & .75 & 2.50\end{array}$

$\begin{array}{lll}.30 & 1.00 & 3.00\end{array}$

$\begin{array}{lll}.30 & 1.00 & 3.00\end{array}$

$\begin{array}{lll}.30 & 1.00 & 3.00\end{array}$

$\begin{array}{lll}.25 & .75 & 2.50\end{array}$

$\begin{array}{lll}.25 & .75 & 2.50\end{array}$

$\begin{array}{lll}.75 & 2.00 & 8.00\end{array}$

$\begin{array}{lll}.25 & .75 & 2.50\end{array}$

$\begin{array}{lll}.25 & .75 & 2.50\end{array}$

$\begin{array}{lll}.30 & 1.00 & 4.00\end{array}$

$\begin{array}{lll}.30 & 1.00 & 3.00\end{array}$

$\begin{array}{lll}.25 & .75 & 2.50\end{array}$

$\begin{array}{lll}.30 & 1.00 & 2.50\end{array}$

$\begin{array}{lll}.30 & 1.00 & 2.50\end{array}$

$\begin{array}{lll}.25 & .75 & 2.50\end{array}$

$\begin{array}{lll}.50 & 1.75 & 6.00\end{array}$

$\begin{array}{lll}.40 & 1.50 & 5.00\end{array}$

$\begin{array}{lll}.25 & .75 & 2.50\end{array}$

$\begin{array}{lll}.30 & 1.00 & 3.00\end{array}$

$\begin{array}{lll}.30 & 1.00 \quad 3.00\end{array}$

$\begin{array}{rrr}.25 & .75 & 2.50 \\ .30 & 1.00 & 3.00\end{array}$

$\begin{array}{lll}.30 & 1.00 & 3.00\end{array}$

$\begin{array}{llr}1.00 & 3.50 & 12.00\end{array}$

$\begin{array}{llr}.30 & 1.00 & 300\end{array}$

$\begin{array}{lll}.30 & 1.00 & 3.00\end{array}$

$\begin{array}{lll}.30 & 1.00 & 3.00\end{array}$

$\begin{array}{lll}.25 & .75 & 2.50\end{array}$

$\begin{array}{lll}.25 & .75 & 2.50\end{array}$

$\begin{array}{lll}.75 & 2.25 & 8.00\end{array}$

$\begin{array}{lll}.25 & .75 & 2.50\end{array}$

$\begin{array}{lll}.25 & .75 & 2.50\end{array}$

$\begin{array}{lll}.30 & 1.00 & 3.00\end{array}$

$\begin{array}{lll}.20 & .60 & 2.00\end{array}$

\section{COLLECTION OF SPENCER SWEET PEAS.}

12 varieties of Spencer Hybrids named for $\$ 1.00 .18$ varieites named for $\$ 1.50$.

SELECT NAMED LARGE-FLOWERED SWEET PEAS.

The varieties listed below have been selected from a much larger list and are, without exception, unsurpassed for freedom of bloom, size of flower and length of stem.

Apple Blossom. Pink standard, with white wings tinged pink. ... $\$ 0.05$

Blanche Burpee. Superb, pure white; immense size, perfect form... .05

Blanche Ferry, Extra-Early. One of the first to flower. Bright rose

Standard, with white wings tinged light pink. .....................

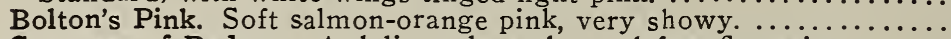

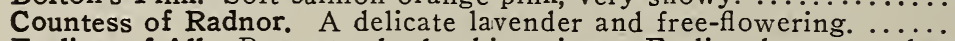

Earliest of All. Rose standard, white wings. Earlier than any other

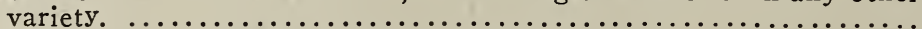

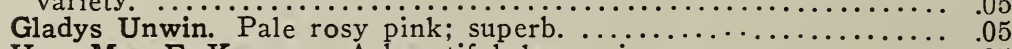

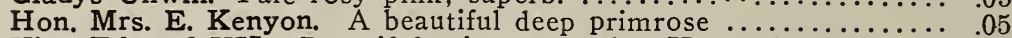

King Edward VII. Beautiful crimson-scarlet, Harvard shade. .... .05

Miss Willmott. Very large orange-pink, on long stems. ...........

Mont Blanc. The earliest pure white variety. .....................

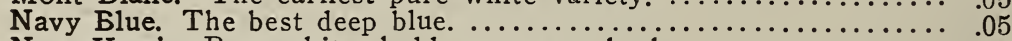

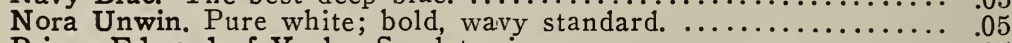

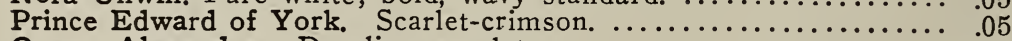

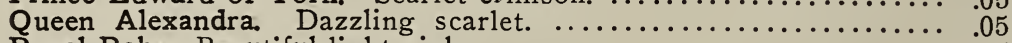

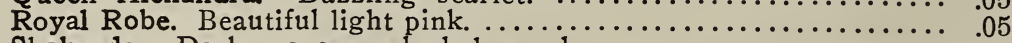

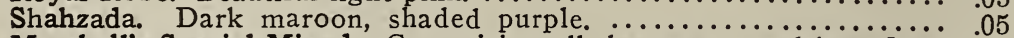

Marshall's Special Mixed. Comprising all the newest and best flow-

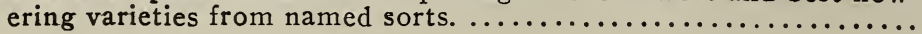

t. Oz. 4 Oz. Lb.

$\$ 0.10 \$ 0.30 \$ 1.00$

$\begin{array}{lll}.10 & .30 & 1.00\end{array}$

.05

.10

$\begin{array}{lll}.10 & .30 & 1.00 \\ .10 & .30 & 1.00 \\ & .00\end{array}$

$.30 \quad 1.00$

.10

.10

$.30 \quad 1.00$

.10
.15
.10

$.30 \quad 1.00$

.10

.10

.10

.15

$\begin{array}{lll}.10 & .30 & 1.00 \\ .10 & .30 & 1.00\end{array}$

$\begin{array}{ll}.50 & 1.50 \\ 30 & 1.00\end{array}$

$\begin{array}{ll}.30 & 1.00\end{array}$

$\begin{array}{ll}.30 & 1.00 \\ .30 & 1.00\end{array}$

$\begin{array}{ll}.30 & 1.00\end{array}$

$.50 \quad 1.50$

$\begin{array}{lll}.10 & .30 & 1.00\end{array}$

$\begin{array}{lll}.10 & .30 & 1.00\end{array}$

. 


\section{NAME AND DESCRIPTION.}

SWEET SULTAN. (See Centaurea).

SWEET WILLIAM (Dianthus Barbatus). A free-flowering favorite.

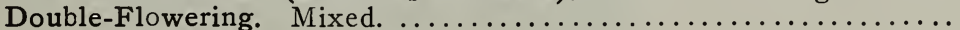
Single-Flowering. Dark crimson.

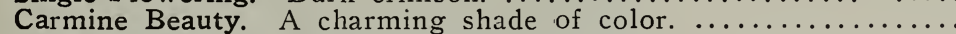

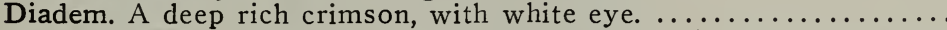

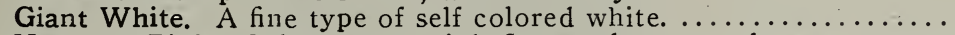
Newport Pink. Salmon rose-pink flowers borne on long stems. ..

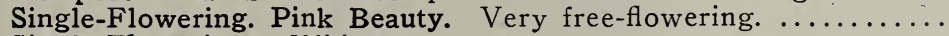
Single-Flowering. White.

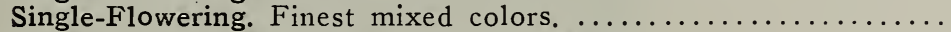
Collection of Sweet William. Six varieties.

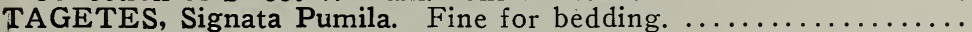

THUNBERGIA. Beautiful rapid-growing climbers. Mixed colors...

TORENIA. Tender trailing plants for vases or baskets.

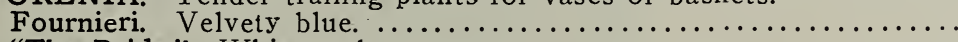
"The Bride." White and rose.

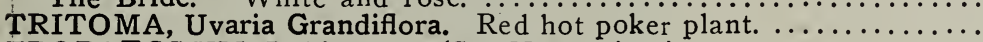
TROPAEOLUM, Lobianum. (See Nasturtium).

VERBENA. One of our most valuable bedding plants.

Helen Willmott. A very pretty bright salmon rose, with white eye. Mammoth Candidissima. Large trusses of white flowers. ........ Mammoth Coerulea. Bright blue and purple in various shades. ...

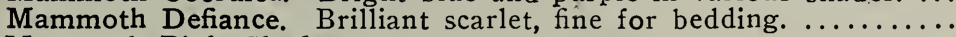

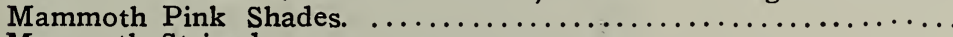

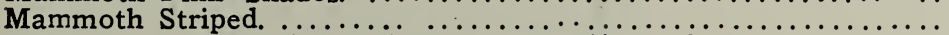

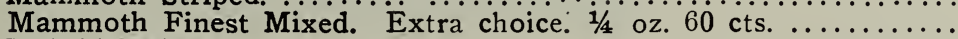
Hybrida Mixed.

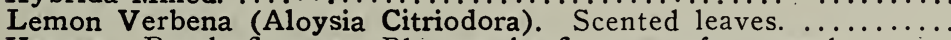
Venosa. Purple flowers. Blooms the first year from seeds. ......

VERONICA Spicata Rosea. Bright rose colored flowers. ...........

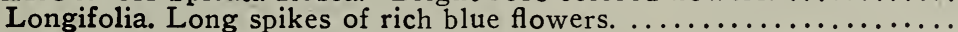

VINCA. Very showy for garden beds. . . . . . . . . . . . . . . .

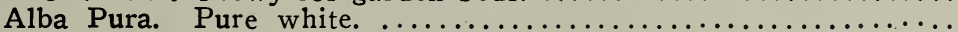

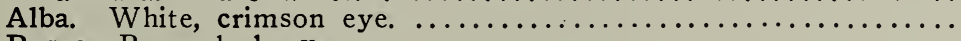

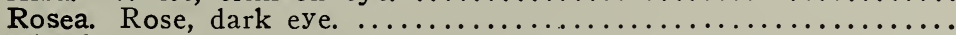

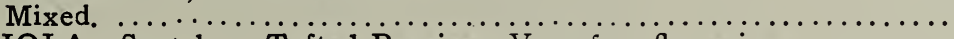

VIOLA. Scotch or Tufted Pansies. Very free-flowering. . . . . . . . .

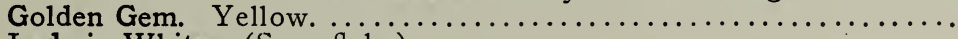

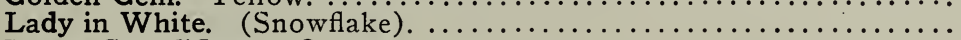

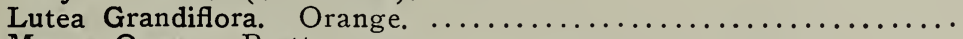

Mauve Queen. Pretty mauve. . . . . . . . . . . . . . . . . .

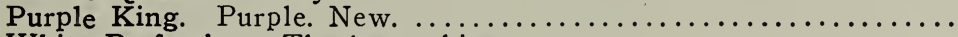

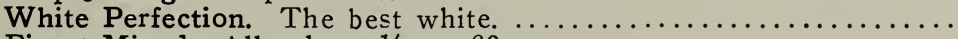

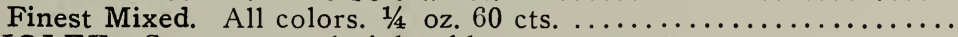

VIOLET. Sweet scented violet, blue.

VISCARIA. Mixed colors; large showy flowers. ...............

WALLFLOWER. Annual. Flowers July to fall from seeds sown in February.

Annual. Early Paris Market. Bright brown.

Annual. Blood-Red.

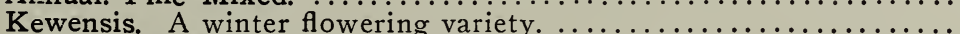

Single Fine Mixed. Hardy varieties. . . . . . . . . . . . . . . .

Double Fine Mixed. Hardy varieties. $1 / 8$ oz. $75 \mathrm{cts} . \ldots \ldots \ldots \ldots \ldots$

XERANTHEMUM. Finest double mixed.

ZINNIAS. (Youth and Old Age). Bushy plants, bearing large showy flowers during summer and fall.

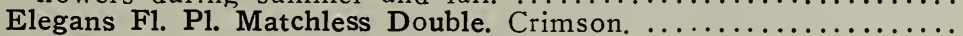

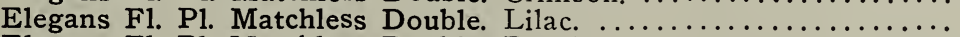

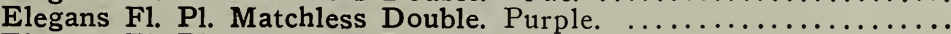

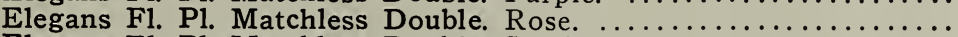

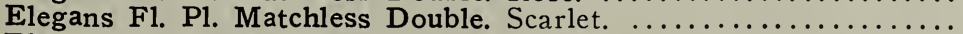

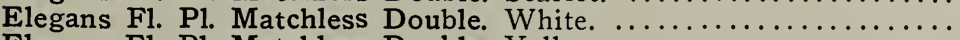

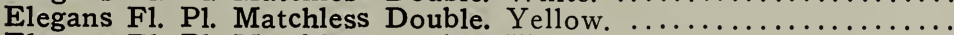

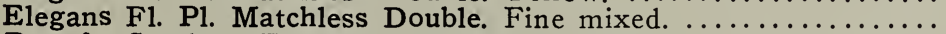

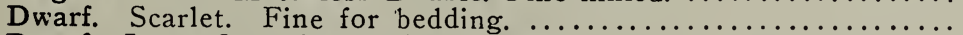

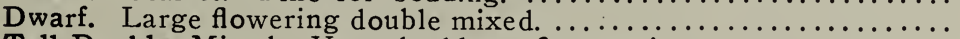

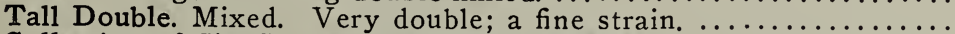

Collection of Six Colors. Mammoth varieties.
Heirht

in feet

$\ddot{1} 1 / 2$
$\cdots$
$\cdots$
$\cdots$
$\cdots$
$\cdots$
$\cdots$
..

$\frac{1}{5}$

1

$\ddot{3}$

1

1

1

$$
\text { .. }
$$$$
\text { .. }
$$

H. A.

.... 2.00

.... 2.00

$\ldots \ldots 2.00$

..... 2.00

.... 2.50

..... 2.00

1. P.

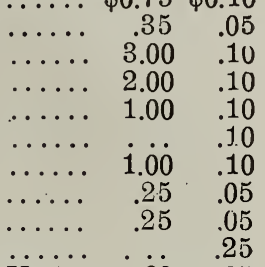

H. A. $.00 \quad .05$

H. H. A.. . . .25

$\ddot{\mathrm{H}} \ddot{\mathrm{P}} \cdot \cdots \quad .25$

... $1.00-05$

G. $\mathrm{P} \cdot \cdots$

.10

$\ddot{\mathrm{H}}$. $\ddot{\mathrm{H}} . \mathrm{P}$.

$\begin{array}{lll}\ldots \ldots & 1.00 \quad .10\end{array}$

$\ldots \ldots \quad 1.00 \quad .10$

...... .7

$\ldots \ldots .100$

H. H. P.

$$
\text { ..... } 2.00 \quad .10
$$

$\ldots \ldots 2.00 \quad .10$

$\ldots \ldots 2.00 \quad .10$

$\ldots \ldots 2.00 \quad .10$

$\ldots \ldots .00 \quad 3.00 \quad .10$

..... 2.0 $\quad .10$

$\ldots \ldots 2.00 \quad .10$

1 H. A. $\begin{array}{lll}1 / 2 & \text { H. H. P. } & .10 \\ & \text { H. A } & \end{array}$

H. A.

1
1
1
1
.
2
2
.
$\cdot$
.
.
.
2
1
$21 / 2$

.....

.30

$\cdots \ldots$

.30

.... 40

H. $\ddot{H} . \dot{P} . \quad \therefore \quad .25$

H. H. P. . . 10

H.A.

.05

H. A.

$\ldots \ldots \quad 60$

$\ldots \ldots .60$

$\ldots \ldots, 60$

$\ldots . .60$

$\ldots \ldots 60$

.....

$\ldots \ldots 50$

$\ldots \ldots .50$

$\ldots \ldots .75$

$\ldots \ldots .50$

$\ldots \ldots .40$ 


\section{HARDY CHRYSANTHEMUIMS}

The Hardy Chrysanthemum should be in every garden as they give an abundance of flowers late in the fall. Plants should be set in April and May to flower the same year.

\section{Large Flowering or Aster Varieties.}

Bradshaw. Silver pink, full flowers.

Elkton. Light pink, large flowers.

Findon. Violet rose.

Fred J. Red orange.

Germania. Large straw white.

Julia Largravere. Crimson maroon.

Lelia. Bright brick-red.

Loreley. Yellow, tinged pink.

Mrs. Vincent. Deep violet-red.

Peto. Rich bronze.

Prince of Wales. The best pure white.

Queen of Whites. Creamy white.

Silver Queen. Light silver pink.

Sir Michael. Lemon-yellow.

St. Illoria. Silver rose.

Sylvia. Scarlet bronze.

Triumph d'Or. Rich golden yellow.

Urith. Bronze, tipped yellow.

\section{Small Pompon or Button Varieties.}

Alice Carey. Pure yellow.

Baby. Smallest golden yellow.

Cerise Queen. Cerise pink.

Dawn. Daybreak pink.

Eleganta. Deep rose, shaded white.

Henrietta. Bronze, yellow edge.

James Boone. Pure 'white.

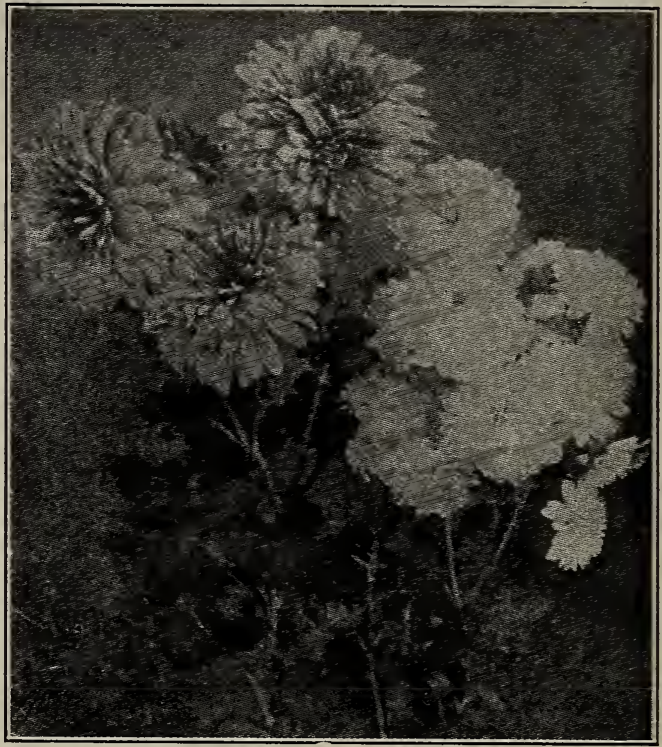

Hardy Chrysanthemums.

\section{Single Flowering Varieties.}

Aron. Bronze scarlet.

Garza. White with quilba petals.

Little George. Violet red.

Pink Daisy. Light pink.

Rosy Morn. Silver pink.

Providence. Early white.

Wallis. Pure yellow.

10 cts.; dozen, $\$ 1.00 ; 100, \$ 6.00$.

\section{Anemone Varieties.}

Barney. Golden bronze.

Furnessia. Silver white.

Lady Olivia. Beautiful white.
Oban. Silver pink.

May Suydan. Bronze.

Meyer's Perfection. Pure white.

Plants from 2 in. pots. Each 10cts.; dozen, $\$ 1.00 ; 100, \$ 6.00$.

\section{HARDY EARLY FLOWERING CHRYSANTHEIMUMS.}

The early flowering of Chrysanthemums are of great value for out-door planting. They are all large-flowered and mature their bloom early enough to avoid being hurt by frost.

The following list are selected from a large number of varieties and are selected for their freedom of bloom and variety of colors.

Chaldon. Large flowers reddish crimson in color with gold tips to the florets.

Eden. Beautifully formed flowers, rose pink in color.

F. Bannister. Deep golden yellow, flowers medium size, medium height.

Glory of Seven Oaks. Very free-flowering, golden yellow color.

Groachers Crimson. Bright crimson, very large flowers, dwarf habit.

L'Argentuillais. The best of the red varieties; fine for cutting.

Leslie. Golden yellow in color; very early and free-flowering.

Maduse. Flowers rather loosely built; terra cotta bronze in color.

Mignon. One of the finest varieties; flowers rosy-pink; medium height.

Nina Blick. Very dwarf growing; golden bronze changing changing to yellow.

Miss F. Collier. A tall variety with white flowers.

Normandie. Very delicate pink or white, varying under growing conditions.

Perle Chatillonaise. Very free-flowering; cream-white in color.

Rosie. Deep rich bronze in color medium height.

Plants from $2 \frac{1}{2}$ in. pots. Each, 15 cts.; dozen, $\$ 1.25 ; 100, \$ 10.00$.

For Novelties and other Chrysanthemums see page 10. 


\section{HARDY ROSES}

\section{Hardy Hybrid Perpetual Roses.}

The plants offered are exceptionally heavy two-year-old stock, which will, under ordinary conditions, give a full crop of flowers this season; and, 'while their main crop is produced in June, they frequently produce fine flowers throughout summer and autumn.

Anna de Diesbach. Clear, bright carmine; very large, finely shaped; full and fragrant.

Baron Bonstetten. Dark crimson.

Baroness Rothschild. Superb rose, of rich satiny pink.

Captain Christy. Delicate rose.

Celeine Forestier. Yellow.

Duke of Edinburgh. Bright carmine.

Frau Karl Druschki. Fine snow-white variety; vigorous grower and very hardy.

General Jacqueminot. Brilliant scarlet-crimson; superb flower.

George Arends. The pink Frau Karl Druschki. Gloire de Dijon. Shaded salmon.

Hugh Dickson. Crimson, shaded scarlet.

John Hopper. Rose-crimson, fine center.

Magna Charta. Bright pink, suffused with carmine; a beautiful rose; strong grower.

Margaret Dickson. The finest white hy'brid.

Mrs. John Laing. Soft pink, of beautiful form; exceedingly fragrant.

Mrs. R. G. Sharmon-Crawford. Deep rosy pink; outer petals shaded with pale flesh.

Paul Neyron. Dark rose; flne extra large flower.

Perle des Blanches. White, pale center.

Ulrich Brunner. Bright, cerise-red; flowers large

Extra strong, 2-year-old, field-grown plants., 30 c. each; $\$ 2.50$ for 10 .

\section{Climbing Roses.}

These are all varieties of established merit, perfectly hardy in the Northern States.

Baltimore Belle. Pale blush; variegated carmine-rose and white; very double; flowers in beautiful clusters.

Dorothy Perkins. Strong as Crimson Rambler. The flowers are borne in clusters; are double, sweet scented and of a beautiful shell-pink.

Flower of Fairfield The ever-blooming Crimson Rambler.

Hiawatha. Deep scarlet with light center; single flowers.

Lady Gay (Wichuriana). Cherry-pink, fading to soft white; very rapid grower.

Philadelphia Crimson-Rambler. Hardy robust grower.

Silver Moon. White with yellow stamens.

Tausendschoen. Soft pink, changing to rosycarmine.

Yellow Rambler. Similar to 'Crimson Rambler, and perfectly hardy; yellow trusses.

Strong 2-year-old plants, 25c. each $\$ 2.00$ for 10

\section{Standard, or Tree- Roses.}

We can supply a number of varieties on Rosa Rugosa stock.

75 cts. each; $\$ 7.50$ per dozen.

\section{Hybrid Tea, or Everblooming Roses.}

This selection will produce a mass of Roses to cut from the entire seeasion. The plants have been grown with special care, and the varieties are the very best for out-door culture; invaluable either for display or cutting, and hardy with protection.

American Beauty. Deep crimson.

Betty. Salmon shaded yellow.

Cecile Brunner. The Sweetheart Rose. Small bright rose flowers.

Countess of Gosford. Salmon pink with saffron yellow at base of petals.

Dean Hole. Carmine and salmon.

Duchess of Albany. Deep rosy-pink.

Duchess of Wellington. Saffron yellow.

Earl of Warwick. Salmon pink.

Edu. Meyer. Shaded red and orange.

Etoile de France. Fine ivelvety crimson flowers.

Franz Deegan. Golden yellow.

Grace Darling. Creamery white, flushed pink.

General Mac Arthur. Crimson.

George C. Ward. Orange vermillion.

Gloire de Chedarn Guinoisseau. Vermillion rose Gruss an Teplitz. A perfect crimson scarlet.

Harry Kirk. Deep sulphur-yellow.

Jonkheer J. L. Mock. Carmine changing to imperial pink.

Kaiserin Augusta Victoria. This is the finest and largest white rose.

Killarney. Bright, rich coral pink.

Lady Ashtown. The best bright pink.

Lady Hillingdon. Canary yellow.

Laurent Carl. Velvety-carmine.

Liberty. Flowers are of large size, magnificent color, rich, velvety crimson.

Lyon-Rose. 'Coral red, shaded with yellow; very fragrant.

Mme. Abel Chatenay. A grand bedding rose; color rosy-carmine shaded salmon.

Mme. Caroline Testout. Clear, brilliant pink, without shading of any kind.

Mme. Jules Grolez. The color is China rose, passing to clear, rich satiny pink.

Mme. Ravary. Beautiful orange yellow.

Mamman Cochet. A magnificent pink rose.

Mamman Cochet White. White.

Mildred Grant. Blush white, tinted pink.

Molly Sharman Crawford. White.

Mrs. Aaron Ward. Distinct Indian-yellow.

Mrs. Wakefield C. Miller. Pale salmon and rose.

My Maryland. Salmon pink.

Pharisaer. Tender rosy flowers borne on long, strong stems.

Prince de Bulgarie. Silvery flesh-pink. shaded with salmon.

Richmond, Beautiful pure scarlet-red flowers.

Soleil d'Or. Deep orange and yellow.

Souvenir de la Malmaison. White and flesh.

Sunburst. Extra fine yellow.

White Killarney. A grand rose.

William Shean. Pure pink.

Strong 2-year-old plant, except where priced, $35 \mathrm{cts}$. each; $\$ 3.00$ for 10 .

For MOSS ROSES. BENGAL ROSES. RAMANAS ROSES and SWEETBRIARS. See our Nursery Catalogue. 


\section{JAPAN FERN BALLS.}

\section{Davallia Bullata.}

Fern Roots, about the size of a pencil, woven outside and around a ball of moss.

The roots produce beautiful sprays of ferns from eyes, or buds, at nearly every inch of their length. Thus the whole surface soon becomes covered with fern sprays.

Dormant Balls, 5-inch diameter. Each, 35 cents.

Dormant Balls, 7 to 9 -inch diameter. Each, 50 cents.

New importation arrives in November.

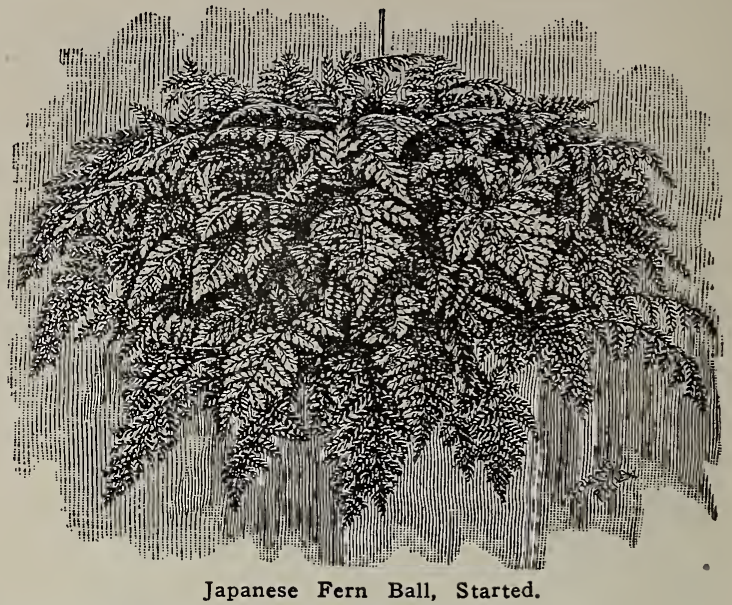

AQUATIC PLANTS FOR FOUNTAINS, LAKES, FTC. CHOICE HARDY NYMPHAEAS.

The following are a selection of the best hybrids for ponds and fountains. We recommend planting in May.

N. Andreana. Flowers beautiful red and yellow $\ldots \ldots \ldots \ldots \ldots \ldots \ldots \ldots \ldots \ldots \ldots \ldots$

Eugenia de Land. Extra large, deep rose pink f owers. $\ldots \ldots \ldots \ldots \ldots \ldots \ldots \ldots \ldots, \quad 2.00$

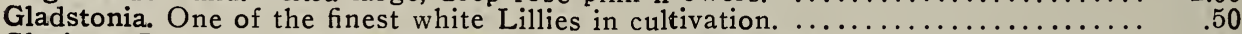

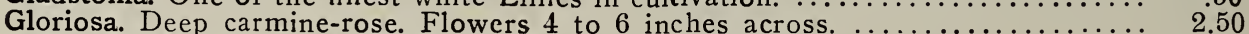

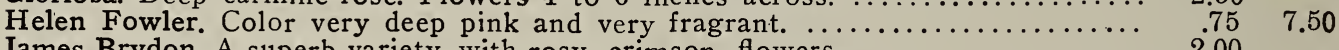

James Brydon. A superb variety, with rosy- crimson flowers. $\ldots \ldots \ldots \ldots \ldots \ldots \ldots \ldots$
Marliacea albida. Flowers large white, stamens yellow, fragrant. $\ldots \ldots \ldots \ldots \ldots \ldots$

Marliacea carnea. A soft flesh pink, deepening at the base of petals. $\ldots \ldots \ldots \ldots \ldots, \quad .75 \quad 7.50$

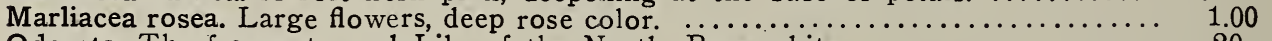

Odorata. The fragrant pond Lily of the North. Pure white. . . . . . . . . . . . . . . . $\quad .20 \quad 2.00$

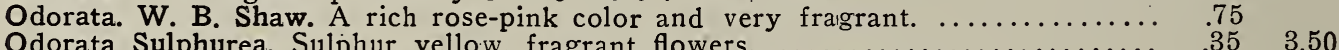

Odorata Sulphurea. Sulphur yellow, fragrant flowers. $\ldots \ldots \ldots \ldots \ldots \ldots \ldots \ldots \ldots \ldots$
Pygmaea. The smallest water Lily in cultivation. Pure white. $\ldots \ldots \ldots \ldots \ldots \ldots \ldots$

Sioux. Large flowers of rich brassy yellow, shaded red. $\ldots \ldots \ldots \ldots \ldots \ldots \ldots \ldots \ldots, 2.00$

William Falconer. The most briliant dark red variety. .......................... 3.00

\section{TENDER NYMPHAEAS. (Day Blooming.)}

Tender Nymphaeas should be planted about the first of June, when warm, settled weather is assured.

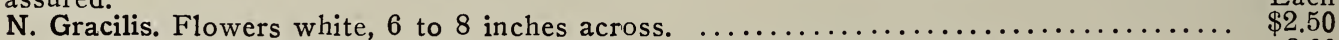

N. Mrs. C. W. Ward. Color deep rosy-pink with golden-yellow stamens. . .......... 2.00

N. Pulcherrima. A beautiful light blue variety. $\ldots \ldots \ldots \ldots \ldots \ldots \ldots \ldots \ldots \ldots \ldots \ldots, 2.00$

N. William Stone. A rich violet blue. Very desirable. . . . . . . . . . . . . . . . . . . 2.00

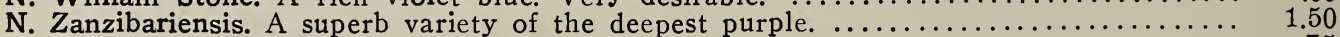

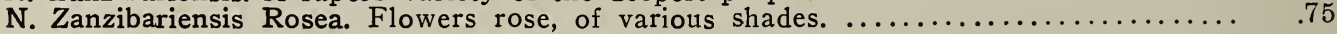

\section{N E I U IM B I U IM S .}

They are of easy culture and are hardy providing the tubes are kept free from frost.

N. Album Graniflorum. Large pure white flowers. $\ldots \ldots \ldots \ldots \ldots \ldots \ldots \ldots \ldots \ldots \ldots . \ldots 2.50$

N. Perkinensis Rubrum. Flowers brilliant rosy crimson. $\ldots \ldots \ldots \ldots \ldots \ldots \ldots \ldots \ldots \ldots \ldots \ldots, 4.00$

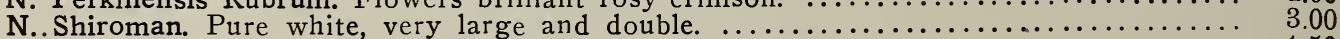

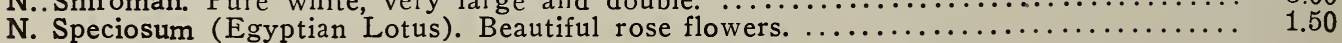

\section{MISCELLANEOUS ACQUATICS. Each Dozen}

Acorus Japonica Variegata. Varicgated Sweet Flag. ...................... $\$ 0.25 \quad \$ 2.50$

Cyperus Alternifolius. An excellent plant for growing in water and damp places. $\quad .15 \quad 1.50$

Eichhornia Crassipes Major (Water Hyacinth). A very showy floating aquatic, bearing flowers of a delicate lilac-rose in trusses. ............................... $\quad 20 \quad 2.00$

Jussiaea Longifolia. Rich golden-yellow flowers. $\ldots$ good plant for tubs or planting on edge of

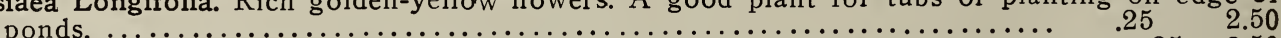

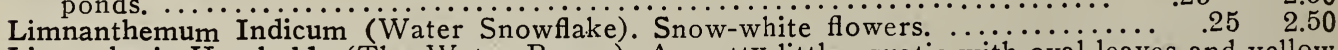

Limnocharis Humboldt (The Water Poppy). A pretty little aquatic with oval leaves and yellow

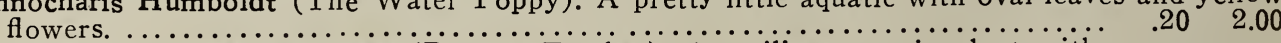

Myriophyllum proserpinacoides (Parrots Feather). A trailing aquatic plant with

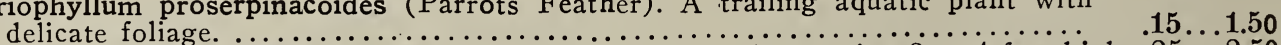

Scirpus Tabernaemontana Zebrina. $\mathrm{A}$, variegated hardy rush, growing 3 to 4 feet high. .25 . 2.50 


\section{B E D D I N G L A N T .}

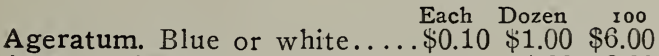

Alternanthera. In variety... $\quad . . .1 .006 .00$

Asters. Double assorted colors $\quad .0$ ว $\quad .30 \quad 2.00$

Begonia Vernon. ............... .10 $1.00 \quad 5.00$

Begonia Luminosa. ................. $.10 \quad 1.00 \quad 5.00$

Caladium Esculentum. Ele-

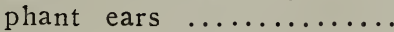

CANNAS. From 3 in. pots..

Alphonse Bouvier. Crimson. $\quad .15 \quad 1.5010 .00$

Egandale. Dark leaves....

Florence Vaughan. Yellow, spotted crimson. ........

Gladiator. Yellow, spotted

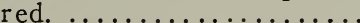

Hiawatha. Bronze. Rose pink

King Humbert. Scarlet....

Madame Crozy. Red and yellow.

Pennsylvania. Vermillion scarlet. ...............

Richard Wallace. Canary yellow. ...............

Queen Charlotte. Orange...

Mixed French Varieties ...

Centaurea Gymnocarpa ......

Coboea Scandens. Blue. .....

Coleus. Golden Bedder.....

Coleus. Hero. Dark leaves..

Coleus. Mrs. Hays. Yellow and crimson .............
Dianthus. Hardy pinks.... $\$ 0.10^{\text {Each }} \$ 1.50 \$ 10.00$

Daisy English. Red and white .05 $.50 \quad 4.00$

Forget-Me-Not Blue ...... $.10 \quad 1.00 \quad 6.00$

Fuchsias. Named varieties.. .151 .50

Geranium. Named varieties. $.15 \quad 1.50 \quad 12.00$ Ivy-leaved sorts ........ $.15 \quad 1.50 \quad 12.00$

Heliotrope. Chieftain. Blue. $\begin{array}{llll}15 & 1.25 & 9.00\end{array}$

Heliotrope. Mme. de Blonay

White ..................... $15 \quad 1.25 \quad 9.00$

Lantanas. In variety ...... $\quad .10 \quad 1.00 \quad 6.00$

Lobelias. Blue dwarf ...... $.10 \quad 1000 \quad 7.00$

Lemon Verbena............ $.15 \quad 1.50$

Marigolds. Dwarf French.. .101 .00

Moonflower. White flowers.. .202 .00

Nasturtium. Dwarf, mixed.. .10 1.00 Climbing, mixed colors... $.10 \quad 1.00$

Pansies. Large fancy mixed .05 .50

Petunia. Double varieties.. $.15 \quad 1.50$ Single varieties .......... .10 1.00

Pinks. Hardy varieties....... $.15 \quad 1.50$

Phlox. Annual, mixed ....... .10 1.00

Ricinus. Castor Oil Plants.. $.10 \quad 1.00$

Salvia Bonfire. Scarlet ..... . .10 .75

Salvia Splendens .......... $.10 \quad .75$

Salvia Zurich. Dwarf........ .10 .75

Swainsonia alba rosea. ...... .10

Sweet William. Mixed colors .15

Verbenas. Finest mixed..... .06

Vincas. Rosea and Alba.... .15

Zinnias. Double mixed.... . .05
....

7.00

7.00

4.00

$\ddot{7} .00$

10.00

$\because 00$

6.00

6.00

6.00

$1.50 \quad 10.00$

$.70 \quad 5.00$

1.5010 .00

$.30 \quad 2.00$

\section{CARNATIONS, Choice Varieties.}

Beacon. The best scarlet.

Benora. Color Cream white.

Enchantress. Shell pink.

Enchantress Supreme. Salmon pink.

Mrs. C. W. Ward. Pleasing shade of pink.

Octoroon. Bright crimson.

Plants from $21 / 4$-inch pots (Spring

Field grown plants (Fall delivery), dozen, $\$ 2.00$; per $100, \$ 12.00$.
Rosette. Large dark pink.

White Enchantress. Pure white.

White Perfection. Large white.

White Winsor. A white sport.

White Wonder. Large pure 'white.

Winsor. Clear silver pink.

\section{VIOLET P L A T S.}

Farquhar. Single blue.

Lady H. Campbell. Fine blue. Field grown roots of the above (Fall delivery), $\$ 1.50$ per dozen; $\$ 10.00$ per 100.
Marie Louise. Deep blue.

Princess of Wales. Single blue.

\section{GREENHOUSE PLANTS.}

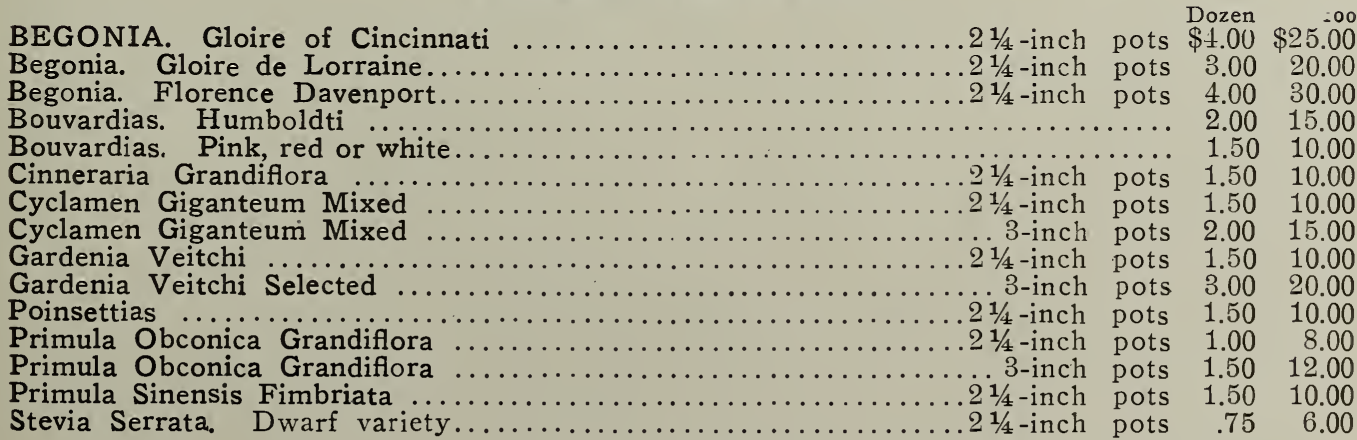




\section{DECORATIVE PLANTS.}

AGAVE Americana. Fine for lawn and porch decoration, 50 cts.; specimens, $\$ 2.50$ to $\$ 10.00$

A. Americana variegata. 75 cts.; specimens, $\$ 2.50$ to $\$ 5.00$.

ARAUCARIA excelsa (Norfolk Island Pine). 6 -in. pots extra fine, $\$ 2.00$ each; $\$ 2.00$ dozen.

ASPIDISTRA lurida. Fine dark broad green leaves; very robust grower and invaluable for the house. $\$ 1.00$ to $\$ 2.00$.

A. lurida variegata. Foliage striped with white; a charming variegated form of the above. $\$ 1.25$ to $\$ 2.00$.
DRACAENA indivisa. Long, graceful foliage; extensivly used for vases. $\tilde{0}$-inch pots, $00 \mathrm{cts}$. each; $\$ 5.00$ per dozen.

FICUS elastica (Rubber Plant). One of the best plants for room decoration. 4-inch pots, 50 cts. each; $\$ 5.00$ per dozen; ̌r-inch pots, 75 cts. each; $\$ 7.50$ per dozen.

MUSA Ensete (Aybssinian Banana). õ-inch pots, 60 cts. each, $\$ 6.50$ per dozen.

PANDANUS Veitchii. Graceful light green leaves, beautifully marked, with broad stripes and bands of pure white. 5-inch pots, $\$ 1.50$; 6 -inch pots, $\$ 2.00$ each.

\section{P A L M S .}

ARECA Lutescens. Very graceful. 5-inch pots, $\$ 1.50$ each; 6 -inch pots, $\$ 1.75$ each.

cocos Weddellana. Fine for table decorations. 3 -inch pots, 30 cts. each; 5-inch pots, $\$ 1.75$ each.

KENTIA Belmoreana. The most popular parlor palm. 3-inch pots, 25 cts. each; 4 -inch pots, 75 cts. each; 5 -inch pots, $\$ 1.25$ each; 6 -inch pots, $\$ 2.00$ each.

K. Forsteriana. This splendid variety is very similar to K. Belmoreana, but of stronger growth, with broader, heavier foliage. 3 -inch pots, 25 cts. each; 4 -inch pots, 75 cts. each; 5 -inch pots, $\$ 1.25$ each; 6 -in. pots, $\$ 2.00$ each.

PHOENIX Roebelenii. Combines the graceful appearance of the Cocos and the hardiness of the Kentia. 4 -inch pots, $\$ 1.00$; 5 -inch pots, $\$ 1.75 ; 6$-inch pots, $\$ 4.00$ each.

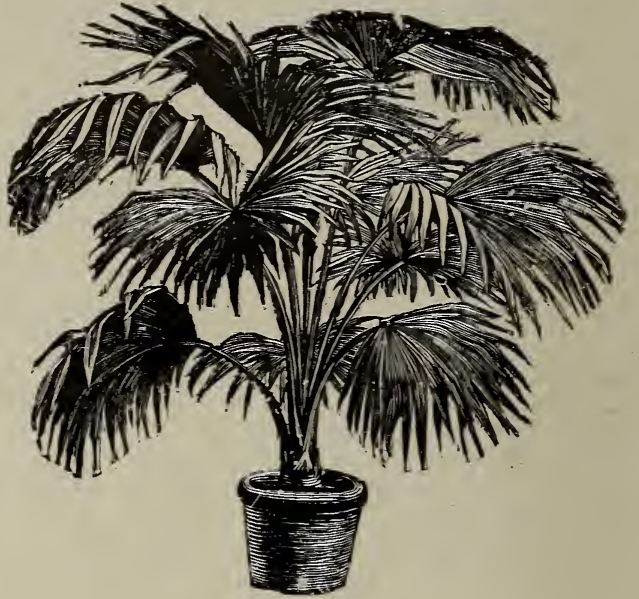

\section{GREENHOUSE FERNS.}

ADIANTUM Croweanum. The hardiest Maiden Hair. 4 -inch pots, 35 cts. each; 5 -inch pots, 50 cts. each.

ASPARAGUS plumosus nanus. Graceful climbing Asparagus; beautiful bright green feathery foliage. 3 -inch pots, $\$ 1.50$ per doz.; extra size, 4 -inch pots, $\$ 2.50$ per dozen.

A. Sprengeri. Fine for baskets. 3-inch pots, $\$ 1.50$ per dozen; 4 -inch pots, 25 cts. each; $\$ 2.50$ per dozen.

Hatcheri. A very rapid grower, making a fuller and heavier string than Plumosus Nanus, $2 \frac{1 / 4}{4}$-inch pots, $\$ 1.25$ per dozen; $\$ 2.50$ per dozen.

Nephrolepis Bostoniensis (Boston Fern). The original type, producing large specimens with long, graceful fronds. 4 -inch pots, 35 cts.; 5 -inch pots, 65 cts.; 6 -inch pots, $\$ 1.00$ each.

NEPHROLEPIS Scotti. Fine for house decoration. 4 -inch pots, 50 cts.; 5 -inch pots, 75 cts.; 6 -inch pots, $\$ 1.00$ each.

N. Superbissima. Dwarf and compact, with dense fronds. 5 -inch pots, 75 cts.

N. Scholzeli (The Plumed Scott Fern). 4-inch pots, 50 cts.; 5 -inch pots, 75 cts. each.

N. Whitmani (The Ostrich Plume Fern). 万-inch pots, 75 cts.; 6 -inch pots, $\$ 1.00$ each.

Pteris Ferns. In variety. For Fern dishes and decorating. Per dozen, $\$ 1.00 ; 100, \$ 8.00$.

Table Ferns. In variety For Fern dishes and ferneries. Per dozen, $S 0$ cts.; 100, $\$ 7.00$. 


\section{Summer Flowering Bulbs}

\section{AGAPANTHUS.}

Umbellatus (Blue Lily of the Nile). A most desirable plant for out-door decoration; planted in large pots or tubs on the lawn or piazza. Each, 20 cts.; dozen, $\$ 2.00$.

\section{AMARYLIS.}

They should be grown in rich, sandy loam, with good drainage, and require abundant moisture when growing; but at their season of rest water should be given sparingly.

Belladonna Major. Large violet and white. Each, 25 cts.; dozen, $\$ 2.50$.

Johnsonii. Crimson striped with white. Extra large bulbs. Each, 50 cts.; dozen, $\$ 5.00$.

vittata. Hybrids. Mixed colors. Each, 50 cts.; dozen, $\$ 5.00$.

Hippeastrum, Veitch's and Ker's New Hybrids. The finest race of Amaryllis in cultivation. Each, $\$ 1.50$; collection of 12 varieties, $\$ 15.00$.

Lycoris Squamigera (Halli). Perfectly hardy variety, producing beautiful pink flowers. Each, 20 cts.; dozen, $\$ 2.00$; per 100 , $\$ 15.00$.

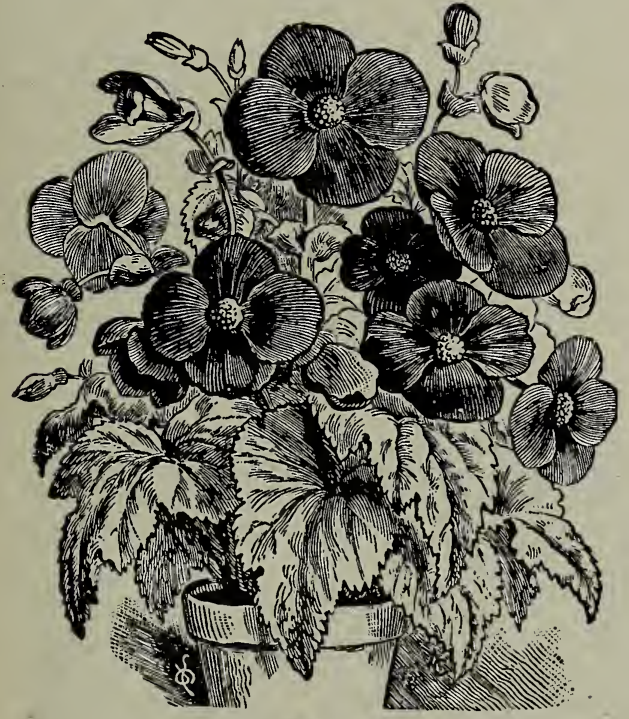

Single Begonia.

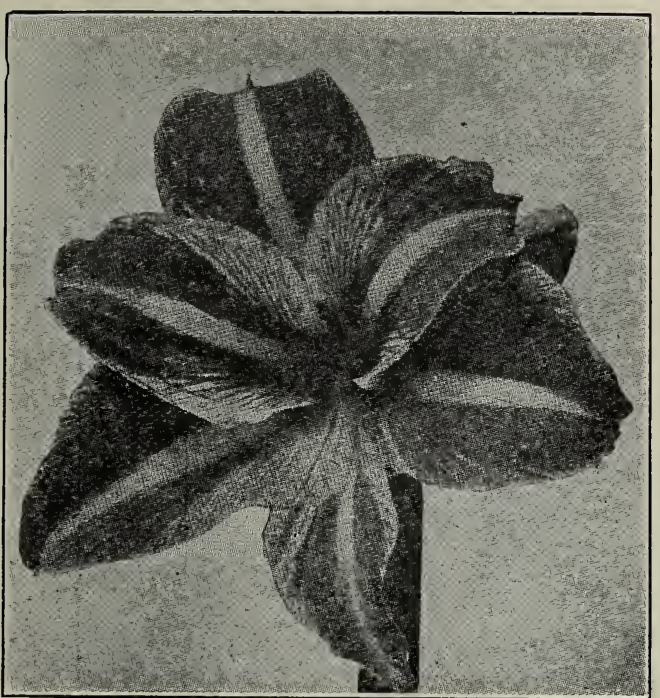

Amaryllis, Vittata.

\section{B E G O N I A S .}

Splendid pot plants for the house or greenhouse and especially valuable for bedding, flowcring in the greatest profusion throughout the summer. For bedding they should be started in hot-bed in March and April.

\section{SINGLE TUBEROUS-ROOTED.}

\begin{tabular}{|c|c|c|c|}
\hline & Each & Dozen & $\$ 500$ \\
\hline $\begin{array}{l}\text { Crimson Pank } \\
\text { Salmon Pink }\end{array}$ & $\$ 0.10$ & $\$ 0.75$ & $\begin{array}{r}\$ 5.00 \\
5.00\end{array}$ \\
\hline Rose ....... & .10 & .75 & 5.00 \\
\hline Scarlet & .10 & .75 & 5.00 \\
\hline White & .10 & .75 & 5.00 \\
\hline Yellow ..... & .10 & .75 & 5.00 \\
\hline Special Mixed $\ldots \ldots \ldots \ldots$ & .05 & .50 & 4.00 \\
\hline $\begin{array}{l}\text { Lafayette. Beautiful rich crim- } \\
\text { son-scarlet, robust habit. }\end{array}$ & .25 & 2.50 & 15.00 \\
\hline
\end{tabular}

DOUBLE TUBEROUS-ROOTED.

\begin{tabular}{|c|c|c|c|}
\hline White & $\begin{array}{r}\text { Each } \\
\$ 0.15\end{array}$ & $\begin{array}{l}\text { Dozen } \\
\$ 150\end{array}$ & $\$ 1000$ \\
\hline Yellow & .40 .15 & 1.50 & 10.00 \\
\hline Rose .. & .15 & 1.50 & 10.00 \\
\hline Scarlet & .15 & 1.50 & 10.00 \\
\hline Pink $\ldots \ldots \ldots$ & .15 & 1.50 & 10.00 \\
\hline Special Mixed & .10 & 1.00 & 8.0 \\
\hline
\end{tabular}

\section{CALADIUM FSCULENTUIM. (Elephant's Ear.)}

Grand tropical plant. A favorite for specimens on the lawn. Height 4 to 5 feet.

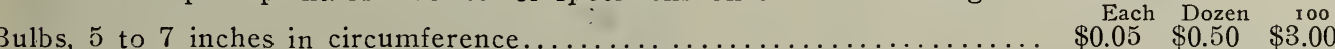

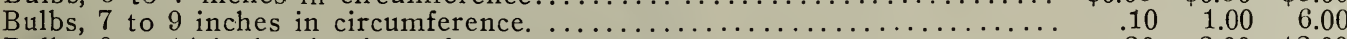

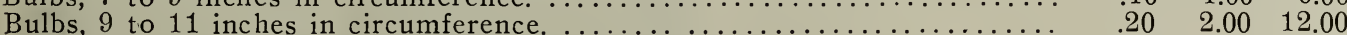

Monster Bulbs, 12 inches and upward in circumference..................

Fancy Leaved. Named varieties. ................................. $\quad .25 \quad 2.50 \quad 18.00$

\section{CALLAS (Richardia.)}

Elliottiana. Flowers are large, rich, dark golden yellow, often 4 to 5 inches

acros the mouth. Leaves are beautifully spotted with white. $\ldots \ldots \ldots \ldots \$ 0.30 \quad \begin{aligned} & \text { Each } \\ & \$ 3.00\end{aligned} \quad \begin{gathered}\text { Ioo } \\ \$ 22.00\end{gathered}$

Spotted Leaf Calla (Richardia alba maculata). Dark green foliage, beauti-

fuly spotted white. ...................................... $10 \quad \begin{array}{r}1.00 \\ 6.00\end{array}$

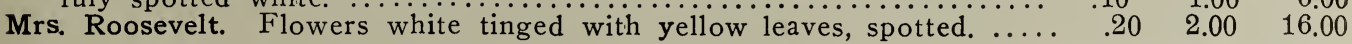




\section{A N N A S.}

Cannas should not be planted until the worm weather sets in, or about May 15th. If planted too early the bulbs are apt tó rot.

The following are a selection of the largest flowering varieties which we can recommend for bedding or borders. We shall be pleased to supply other varieties not named at catalogue prices.

Chas. Henderson. Bright crimson, green foliage; 4 feet $\ldots \ldots \ldots \ldots \ldots \ldots \ldots \ldots \ldots \$ 1.00 \$ 6.00$

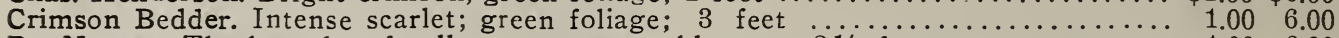

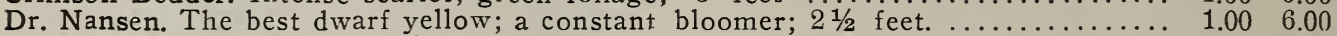

Firebird. New. A clear glistening scarlet flower. with green leaved foliage. ........... $7.00 \quad 50.00$

Florence Vaughan. Golden yellow, spotted with bright red; $2 \frac{1}{2}$ feet. . . . . . . . . . . . $1.00 \quad 6.00$

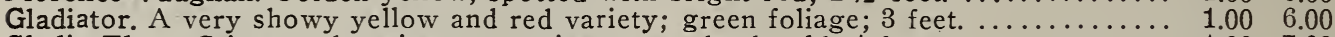

Gladio-Flora. Crimson changing to carmine rose, edged gold; 4 feet. . . . . . . . . . . . $1.00 \quad 7.00$

Hungaria. The ideal pink bedder; large trusses of flowers; 3 feet. . . . . . . . . . . . . $1.00 \quad 6.00$

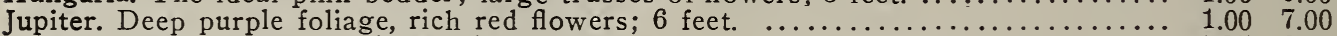

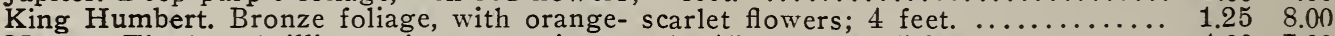

Meteor. The best brilliant crimson; a vigorous healthy grower; 5 feet. $\ldots \ldots \ldots \ldots \ldots, 1.00 \quad 7.00$

Mrs. Alf. Conard. Exquisite salmon-pink; very free flowering; 4 feet. $\ldots \ldots \ldots \ldots \ldots \ldots, 1.00,7.00$

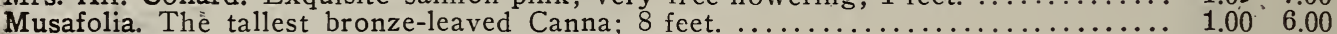

Pennsylvania. Rich shades of orange and scarlet; 6 feet. . . . . . . . . . . . . . . . . $1.00 \quad 6.00$

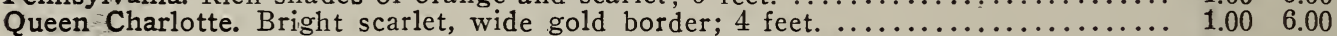

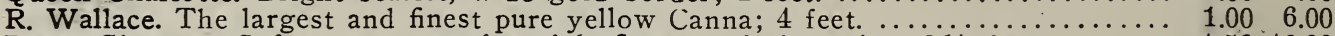

Rosea Gigantea. Soft rose to carmine pink, flowers of giant size; $31 \frac{1}{2}$ feet. .......... 1.5010 .00

Wyoming. Giant flowering, purple foliage, with orange flowers; 7 feet. . . . . . . . $1.00 \quad 6.00$

\section{I N N A M O N V N E.}

Dioscorea Batatas. A rapid growing summer climber, with bright green glossy foliage and spikes of cinnamon-scented white flowers. Each, 5 cts.; dozen, 50 cts.; $100, \$ 3.50$.

\section{A H L I A S}

The renewed popularity of the Dahlia in recent years has brought out many new sorts, and any one wishing to get the cream will find most of them in our collection, which can be recommended either for growing in competition, market purposes, or private collections, and embrace all classifications.

\section{NEW CACTUS DAHLIAS.}

The following are all new varieties, and comprise the cream of the novelties, which have been grown here and proved to be of extra merit.

Aviator. A bright magenta. Quite distinct. C. E. Wilkins. Large flowers; pale sulphur yellow passing to a salmon-pink.

Debutante. A light tint of soft pink, the upper portion of the floret white.

Great Western. A large noble flower of excellent quality; color bright purple.

Indomitable. Mauve lilac; the tips of the florets being of lighter coloring.

Mrs. F. Grinstead. Deep rich crimson, suffused with purple; flower incurved.

Mrs. MacMillan. White in the center, deepening to pink at the tips.

Rev. T. W. Jamieson. Central petals yellow, changing to lilac-rose.

Ruby Grinsted. The center is a soft yellow, suffused rich shade of rosy fawn.

Snowstorm. A large bold white flower of fine form; dwarf and sturdy habit.

T. A. Havemeyer. Clear yellow at base, deepening to bronze.

Wm. Marshall. Rich orange with bright

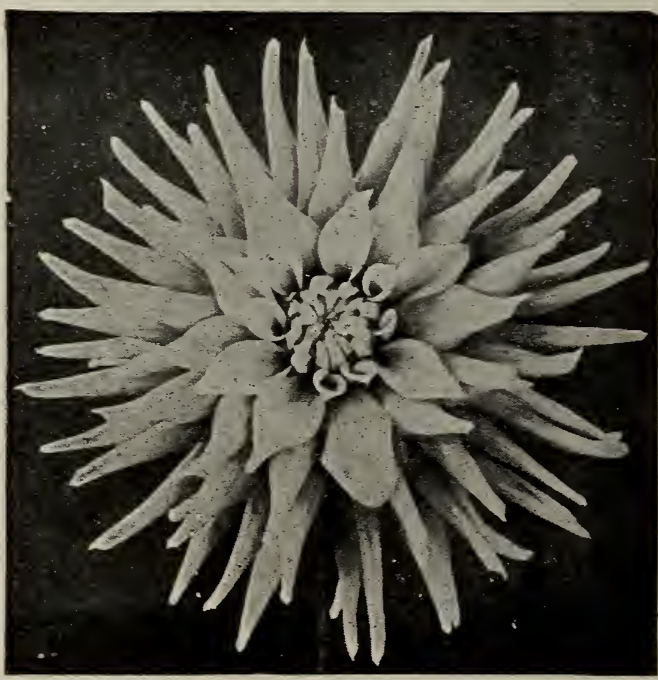

Cactus Dahlia.

yellow in the center.

Strong field grown roots of the above, 50 cts. each, $\$ 5.00$ per dozen. 


\section{DAHLIAS-Continued}

\section{SPECIAL COLLECTION OF CACTUS DAHLIAS.}

Amos Perry. Bright scarlet.

Dainty. Lemon-yellow, shaded rose-pink.

F. H. Chapman. Yellow, shaded with orange.

Floradora. Dark velvety crimson.

Harbor Light. Orange red, overlaid with flame.

J. B. Bryant. Golden yellow.

J. H. Jackson. The largest deep maroon.
Kriemhilde. Delicate pink, shaded rose pink.

Mrs. H. J. Jones. Crimson, with white stripe in center of petals.

Mrs. James Mace. Light pink, shading to white at base of petals.

Standard Bearer. Brightest scarlet.

Winsome. The finest white.

Strong field grown roots of the above. Each 25 cts. doz $\$ 2.50$.

\section{SELECT CACTUS DAHLIAS.}

Containing a very choice collection of the leading varieties.

Aunt Chloe. Dark maroon, shaded black.

Brunhilde. Deep, rich, velvety plum.

Charm. Yellow suffused with bronze red.

Comrade. Fawn color, shading to pink at the tips of the petals.

Coronation. Bright red; fine cut flower.

Countess of Lonsdale. A pleasing blending of amber and salmon-pink.

Dorothy Vernon. Flesh pink, shading to cream and dark pink.

Earl of Pembroke. Bright plum, deeper and velvety in the center.

Edith Groome. Snow-white.

Strong field grown roots of the above $15 \mathrm{cts}$. each; $\$ 1.50$ per dozen.

\section{PAEONY FLOWERED DAHLIAS.}

Large flowers, with petals peculiarly twisted and curved. They are very free flowering and have long, stiff stems.

Cleopatra. Rich, oriental red, base of petals primrose-yellow.

Duke Henry. A lovely shade of soft, dark red

Germania. Dark velvety wine color, shaded with yellow.

Herzog Henrich. A beautiful bright red.

King Edward. Large purple flowers.

King Leopold. The best yellow.

La Riante. One of the finest pink flowers.

Merveille. Orange salmon; large flowers.

Miss Gladys Dawson. Soft yellow rose.

Queen Emma. A charming shade of hollyhockpink, the inner petals banded with gold.

Snowqueen. Extra large pure white flowers.

Solfaterre. Carmine red with yellow center. Strong roots of the above varieties. Each, 25 cts.; per dozen, $\$ 2.50$.

\section{NEW DECORATIVE DAHLIAS.}

A grand selection of the best varieties.

Augusta Nonin. A large clear scarlet flower.

Jeanne Charmet. Bright pink, edged crimson; flowers 6 inches across.

Louis Harriott. A clear lemon-yellow without a shade or blemish.

Lucy Feyrier. A pretty shade of rich rose-pink

Papa Charmet. Bright coral-red, overlaid with a darker shade of velvety maroon.

Perle de Lyon. Pure white; free flowering on long stiff stems.

Santa Cruz. Yellow, suffused and tipped with red.

$$
\text { Each, } 50 \text { cts.; dozen, } \$ 5.00 \text {. }
$$

F. A. Wellesley. The best crimson.

General Buller. Deep velvety, maroon tipped white.

Hobbies Yellow. Clear canary yellow.

Hohenzollern. Gold and bronze orange-red.

Maid of Honor. Peach blossom pink.

Mary Farnsworth. Pure yellow, tipped white. Miss Grace Cook. Deep rose, with nearly 'white tips on petals.

Mrs. Clinton. Deep salmon, shaded red, tinting to yellow at center.

Uncle Tom. The best black Cactus.

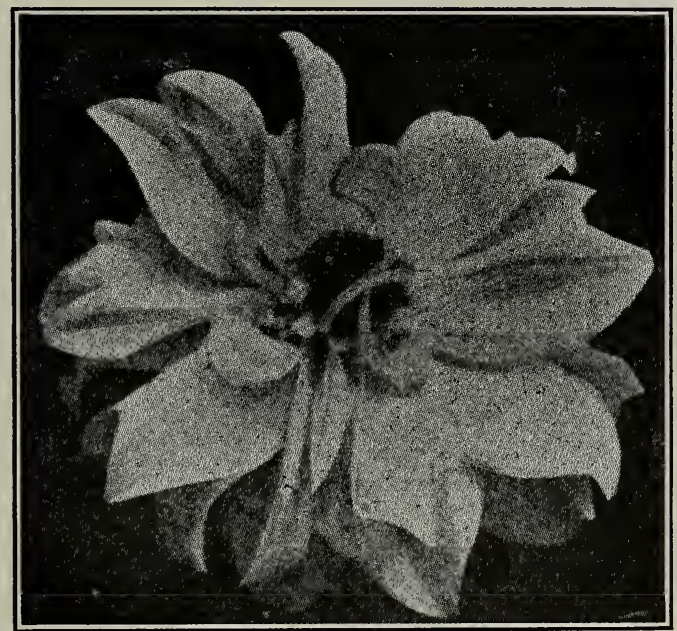

Paeony Flowered Dahlia.

GIANT DECORATIVE DAHLIAS.

These are the largest and most perfect doubleflowering Dahlias.

Cuban Giant. An immense ball of bright maroon.

Gigantea. Creamy white. Very large.

Le Colosse. Bright carmine-scarlet. Early freeflowering.

Mad. van Den Dael. Color shell pink, with deeper markings.

Mrs. Roosevelt. A delicate shade of soft pink. Souv. de Gustave Doozan. A beautiful red; flowers from 6 to 8 inches across.

Yellow Duke. The largest yellow.

Strong roots. Each, 25 cts.; per dozen, $\$ 2.50$. 


\section{DAHLIAS--Continued}

\section{SUPERB DECORATIVE DAHLIAS.}

Our list has been revised, and only contains the best varieties.

Catherine Duer. Bright crimson-scarlet.

Delice. The finest pink decorative.

Frank L. Basset. Carmine purple shaded to blue.

Grand Duke Alexis. A grand flower. Pure white, tinged delicate pink.

Jack Rose. A rich shade of crimson. Very large perfect flowers in great profusion.

Kaiserin Augusta Victoria. White.

Lyndhurst. The best bright scarlet.

Miss Mimmie McCullough. Soft yellow overlaid with bronze.

Perle d'Or. The best white; very large flowers on long stiff stems.

Sylvia. Soft pink, changing to white.

Yellow Colosse. A very large bright yellow.

Virginia Maule. White, suffused shrimp-pink.

Strong roots. Each, 25 cts.; per dozen, $\$ 2.50$.

\section{CHOICE FANCY DAHLIAS.}

A collection of the best distinct varieties.

Eloise. Blush-pink, margined crimson.

Frank Smith. Rich maroon, tipped white.

Gold Medal. 'Canary yellow, striped red.

Olympia. Rose pink, striped crimson.

Prof. Mansfield. Golden yellow, tipped white. Very large.

Progress. Soft rosy lake, spotted crimson. Strong roots. Each, 20 cts.; per doz., $\$ 2.00$.

\section{DOUBLE POIMPON DAHLIAS.}

This class produces small, very double-quilled flowers, which are ideal for bouquet work.

Allie Mourey. Light pink.

Guiding Star. Pure white.

Little Beauty. Delicate schrimp pink.

Klein Domitea. Salmon buff.

Little Herman. Deep red, tipped white.

Vivid. Intense vivid scarlet.

Strong roots. Each, 15 cts.; per dozen, $\$ 1.50$.

\section{DOUBLE CENTURY DAHLIAS.}

Similar to the Century types, excepting they have two or more rows of petals.

Big Chief. Brilliant cherry red, edged velvet maroon.

Merry Widow. Large deep scarlet flowers.

Souv. De Franz Liszt. Deep rich garnet.

Variegated Liszt. Dark red at the base shading to bronze at the tips of petals.

Strong roots. Each, 25 cts.; per dozen, $\$ 2.50$.

\section{CHOICE SHOW DAHLIAS.}

The following are a selection of the best varieties for cut flowers:

Agent. Delicate soft pink perfect flowers on stout stems.

Arabella. Pale primrose, tipped and shaded old rose and lavender.

Black Diamond. Rich velvety maroon, the best dark show Dahlia.

David Johnson. Large salmon and rose flowers. Very distinct.

John Thorpe. Very large, soft rich pink.

Lady G. Herbert. White tipped deep purple. Flowers on long stems.

Lemon Beauty. Soft shade of lemon-yellow.

Miss May Lomas. Delicate pure white, suffused with soft pink.

Modesty. One of the best; delicate blush.

Red Hussar. Intense scarlet-crimson.

Storm King. The finest white show Dahlia.

Yellow Livoni. Soft pure creamy yellow.

Profuse bloomer, full center.

Strong roots. Each, 25 cts.; per doz., $\$ 2.50$.

\section{CHOICE SINGLE DAHLIAS.}

These have become very popular for' cutting purposes. We list a few of the standard varieties.

Alba Superba. A grand pure white.

Ami Barrillet. Flowers rich garnet.

Fashion. Crimson maroon, flamed purple.

Gaillardia. Golden yellow, with disc of red.

Jack. Very brilliant fiery scarlet.

Mary. Color clear, soft pink.

Rosalind. Rosy lake, suffused crimson.

St. George. Very large, pure yellow.

Striking. Maroon tipped white.

Sylvion. Bright scarlet, striped white.

Twilight. Soft lávender, shaded rose; very profuse.

Wildfire. A very rich scarlet.

White Cross. Soft rosy lake, with a white stripe through the center of each petal.

Strong roots. Each, 15 cts.; per dozen, $\$ 1.50$.

\section{CENTURY DAHLIAS.}

These comprise a large variety and range of Single Dahlias. Producing flowers from 5 to 7 inches in diameter.

Crimson Century. Deep rose ground with crimson blotch.

Gorgeous. Dazzling scarlet with white stripe. Harvard. An intense crimson.

Maroon Century. Maroon, shaded plum.

Pink Century. Delicate shell pink.

Rose Pink Century. A beautiful rose-pink.

Twentieth Century. Rosy crimson, with white tips and disc.

White Perfection. Snowy white.

Yellow Century. Canary yellow.

Strong roots. Each, 25 cts.; per dozen, $\$ 2.50$.

\section{NOVELTIES IN DAHLIAS.}

A complete list of the new varieties with description is given on page 9 of this catalogue.

\section{G I O R I O S A. Rothscildiana.}

This magnificent greenhouse plant is adapted for specimen plants or as a greenhouse climber. The flowers of this variety are bright scarlet with yellow center. Strong bulbs. Each $\$ 1.50 ;$ dozen, $\$ 16.00$. 


\section{G L A D I O L U S.}

There are no other summer flowering bulbs so satisfactory, needing so little attention and thriving so well in almost any ordinary soil as the Gladiolus. Set the bulbs from three to six inches apart in rows, or for massing six inches apart, and about four inches deep.

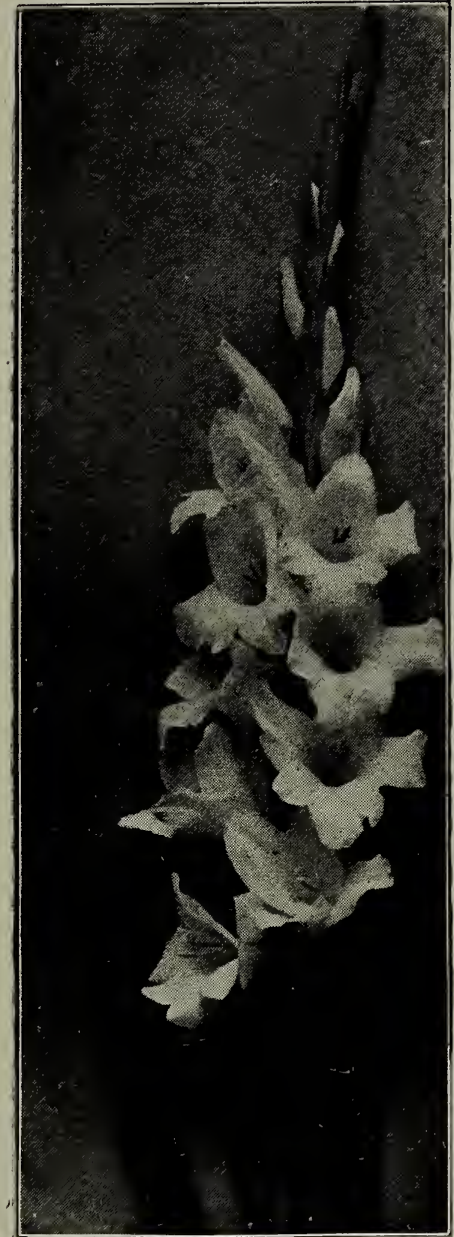

Gladiolus Snow King.

\section{NAMED HYBRID GLADIOLUS.}

Alaska. A pure white variety; large

spike of well-formed flowers. .... $\$ 0.45 \$ 4.50 \$ 30.00$

America. Large flower beautiful flesh pink; beautiful for cutting; extra large bulbs. ....................

Attraction. Deep dark, rich crimson, white throat $\ldots \ldots \ldots \ldots \ldots \ldots \ldots$.

Augusta. Lovely pure white, with blue anthers. $\ldots \ldots \ldots \ldots \ldots \ldots \ldots \ldots$.

Blanche. Large flowers, pure white with faint marks. ..............

Blue Jay. (Baron Hulot). The finest blue Gladiolus.

Bowdoin. Very large flower, light orange-scarlet, with pure white throat.

Brenchleyensis. Vermillion scarlet. ....

Canary Bird, Fine yellow; extra good...

Charmer. Soft mauve pink; lighter in the throat, which is penciled carmine lake.

$.05 \quad .40$

.05

$\begin{array}{lll}.25 & 2.50 & 17.00\end{array}$

$\begin{array}{lll}.10 & .60 & 4.00\end{array}$

$\begin{array}{lll}.15 & 1.50 & 10.00\end{array}$

$\begin{array}{lrr}.05 & .30 & 2.00\end{array}$

$\begin{array}{lll}.15 & 1.25 & 9.00\end{array}$

Dazzler. Large vivid slamon-scarlet with throat blotch of red-orange; fine long spike, well filled. .............

Europe. Pure snow white, with long spikes and large flowers. ........

Fire King. Long graceful spikes of intense fire scarlet flowers. ......

Hollandia. Similar to Brenchleyensis, only rosy-yellow in color. .........

Kunderi "Glory." Each flower petal is ruffled and flutted which expand wide open and are cream-pink with a crimson stripe color . ..............

Lavender Queen. Beautifui blending of lavender and lilac. Entirely new colors and very distinct. ........

Mrs. Francis King. Light scarlet of pleasing shade; long spikes; one of the best for decorating; extra large bulb. .........................

Mrs. Frank Pendleton. The flowers are very large, of a lovely flushed salmon-pink, with brilliant carmine blotches in the throat. ............

Niagara. Beautiful cream shade with lower petals blending to yellow inside; throat splashed carmine. .....

Octoroon. A beautiful salmon-pink; very distinct. ...............................
Panama. A seedling of "America," resembling he parent except that it is a

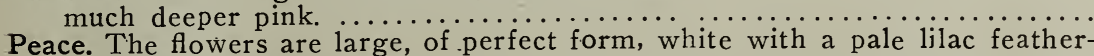

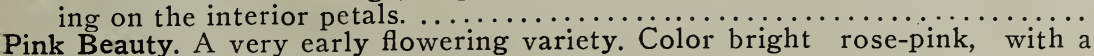
darker blotch. A good forcer. .....................................

Princeps. Rich crimson with broad white blotches across the lower petals. ... .10

$.25 \quad 2.50 \quad 5.00$

$\begin{array}{lll}.40 & 4.00 & 30.00\end{array}$

$.10 \quad 1.00 \quad 10.00$

$\begin{array}{lll}.35 & 3.50 & 25.00\end{array}$

$.05 \quad .50 \quad 3.00$

$\begin{array}{lll}.15 & 1.50 & 10.00\end{array}$

$.35 \quad 3.50 \quad 25.00$

$.10 \quad .50 \quad 3.00$

$.25 \quad 2.50 \quad 17.00$

$\begin{array}{lll}.20 & 2.00 & 12.00\end{array}$

$\begin{array}{lll}15 & 1.55 & 10.00\end{array}$

$20 \quad 2.00 \quad 1.50$

$\begin{array}{lll}15 & 1.50 & 10.00\end{array}$

$.05 \quad .30 \quad 2.00$

Reine Blanche. Pure white with the exception of a small purple blotch at the

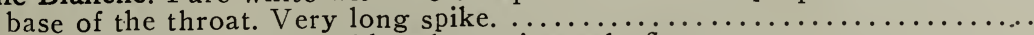

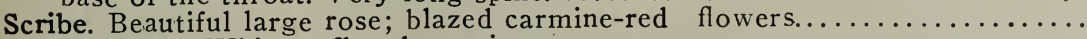

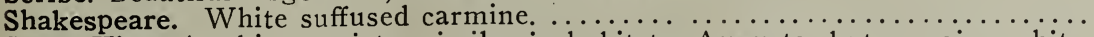

Snow King. A white wariety, similar in habit to Augusta, but remains white.

Sulphur King. Deep pure yellow; the best of its color. . . . . . . . . .

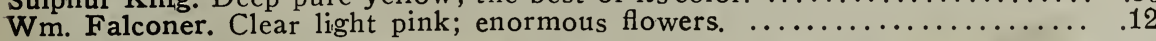

$.60 \quad 4.00$

$\begin{array}{lll}.20 & 2.00 & 12.00\end{array}$

$\begin{array}{llr}10 & 1.00 & 7.00\end{array}$

$\begin{array}{lll}10 & 1.00 & 7.00\end{array}$

$1.00 \quad 7.00$

$3.00 \quad 18.00$

$1.25 \quad 9.00$

"We shall be pleased to supply any variety not listed at current prices." 


\section{GLADIOLUS IN MIXTURE.}

Our mixtures are made up from fine varieties and are all selected first size bulbs Marshall's Matchless Hybrids. This is our general mixture, and is composed Dozen roo: of fine sorts in all colors, in extra large size bulbs only ........... $\$ 0.25$

Childsii, Mixed. Superb large-flowered, first quality from named varieties and

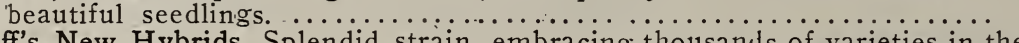

Groff's New Hybrids. Splendid strain, embracing thousands of varieties in the greatest diversity of colors. Mixed hybrids seedings, first selection.....

Primulinus Hybrids. Shade of yellow, orange and crimson; extremely vigorous and healthy growers, blooming in july and August..... Each. 10 cts.....

$\begin{array}{lll}.50 & 3.00 & 25.00 \\ .30 & 2.00 & 18.00 \\ .75 & 5.00 & 40.00\end{array}$

\section{MIXED GLADIOLUS IN SEPARATE SHADES.}

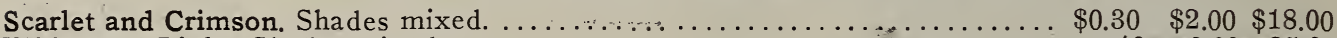

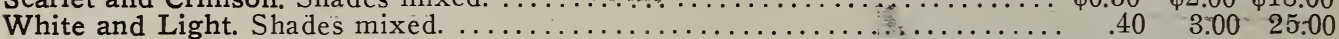

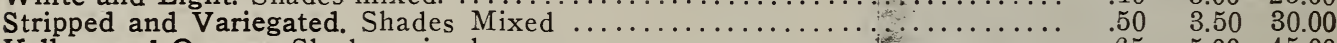

Yellow and Orange. Shades mixed. ......................

\section{G L O X I N I A S.}

These are desirable summer-flowering plants for both greenhouse and window.

Colestinum. Blue.

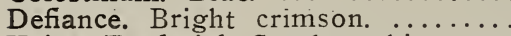

Kaiser Frederick. Scarlet, white margin

Large-Flowering. All colors; mixed.
Kaiser William. Blue, white border. $\$ 0.15 \quad \begin{gathered}\text { Dach } \\ \$ 1.50\end{gathered} \$ 10.00$

Mount Blanc. Snow-white. ........ $15 \quad 1.50 \quad 10.00$

Tigridia Spotted ................ $15 \quad .150000$

\section{HYACINTHUS CANDICANS. Cape Hyacinth.}

A snow-white summer-flowering Hyacinth, growing 3 to 5 feet in height, gracefully surmounted with from 20 to 30 pure white bellshaped flowers. Each, 5 cts.; dozeri, 50 cts.; $100 . \$ 3.00$.

\section{ISMENE. Calathena Grandiflora.}

The flowers are very large, like an Amaryllis, novel in form and snow-white in color. Each, $10 \mathrm{cts}$; dozen, $\$ 1.00 ; 100, \$ 8.00$.

\section{I L I E S.}

When grown in the border or open ground they should remain undisturbed for years, frequent removals being injurious. In the autumn give the bulbs a heavy mulching of leaves: coars manure or boughs will prove highly beneficial. Plant all Lilies at least six inches deep.

Auratum (Golden-Banded Lily). The grandest of all hardy Lilies.

Extra large bulbs, 9 to 11 inches.

Each Dozen 100

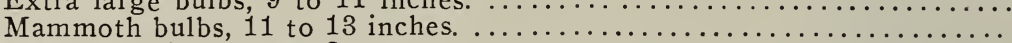

$\begin{array}{lrl}\text { Each } & \text { Dozen } & \text { 100 } \\ 0.20 & 2.00 & \$ 15.00\end{array}$

Batemanni. Redish-orange flowers. .. ............................... $20 \quad 2.00 \quad 15.00$

Canadense. Lovely nodding blossoms, bell-shaped, yellow spotted black. .. $\quad \begin{array}{rrrr}10 & 1.00 & 8.00\end{array}$

Elegans Robusta. Orange, spotted black. .......................... $\quad .10 \quad 1.00 \quad 6.00$

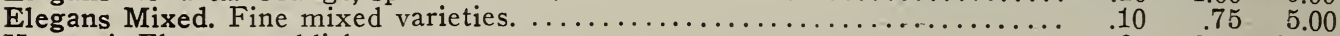

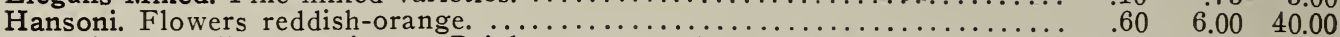

Henryi. The yellow Speciosum. Bright orange yellow; selected bulbs. . ....... $\quad .60 \quad 6.00 \quad 45.00$

Myriophyllum. Flowers white, slightly suffused pink, with yellow center. . . . $\quad 1.50 \quad 15.00$

Pardalinum (Leopold Lily). Rich scarlet and yellow flower, spotted with rich

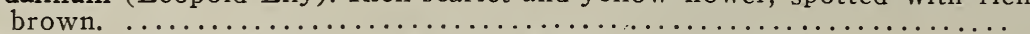

Speciosum Album. Beautiful pure white flowers of large size.

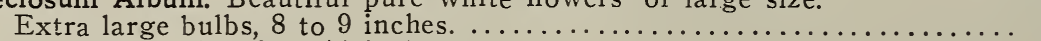

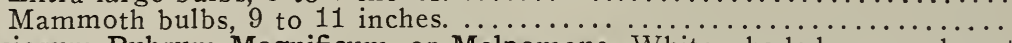

$\begin{array}{lll}.15 & 1.25 & 10.00\end{array}$

$\begin{array}{lll}.20 & 2.00 & 14.00\end{array}$

Speciosum Rubrum Magnificum, or Melpomone. White, shaded rose and spotted deep red.

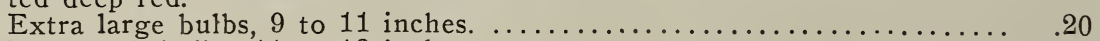

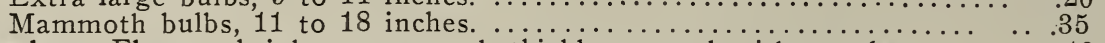

Superbum. Flowers bright orange red, thickly spotted with purple. ....... $\quad .10$

Trigrinum Splendens (Single Tiger Lily). Rich scarlet, with black spots. .... .10

Trigrinum Flore Pleno (Double Tiger Lily). Bright orange red, with black

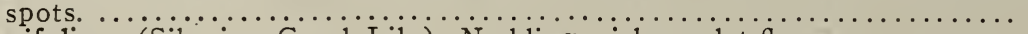

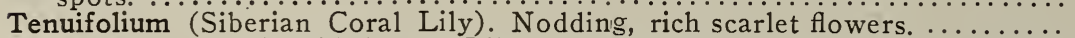

Umbellatum. A splendid, hardly Lily. Colors range from deepest red through

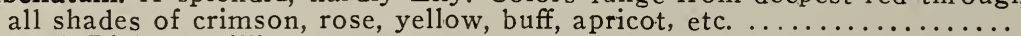

Wallacei. Rich vermillion-orange. 


\section{LILY-OF-THE-V̈ALLEY CLUIMPS.}

Lange clumps of Lily-of-the-Valley for outside planting and naturalizing. These clumps will throw from 15 to 20 spikes of flowers. Each 30 cts.; dozen, $\$ 3.00 ; 100$, $\$ 25.00$.

\section{MADEIRA OR MIGONETTE VINE.}

A beautiful climbing Vine of rapid growth. Each, 5 cts.; dozen, 50 cts.; 100, $\$ 3.50$.

\section{MILLA BIFLORA.}

Pure white flowers nearly $2 \frac{1}{2}$ inches in diameter. Each 10 cts.; doz. 75 cts.; $100 \$ 4.00$.

\section{MONTBRETIAS.}

Hardy summer-flowering bulbous plants that are becoming more popular every year. They should be planted in groups and left undisturbed.

Bouquet Parfait. Vermillion with yellow center.

Crocosmiaeflora. Large, bright orange, tinted scarlet.

Drap d'Or. Orange-yellow.

Eldorado. Dark yellow.

Etoile de Feu. Bright vermillion and scarlet; large flowers.

Gerbe d'Or. Golden-yellow.

Pottsii: Orange and scarlet; very free flowering.

Rayon d'Or. Ochre-yellow and brown.

Any of the above varieties:

Dozen, 20 cts.; $100, \$ 1.50 ; 1,000, \$ 12.00$.

\section{OXALIS.}

Summer-flowering for beds or borders.

Deppei. Pure white ........... $\$ 0.10 \$ 0.60$

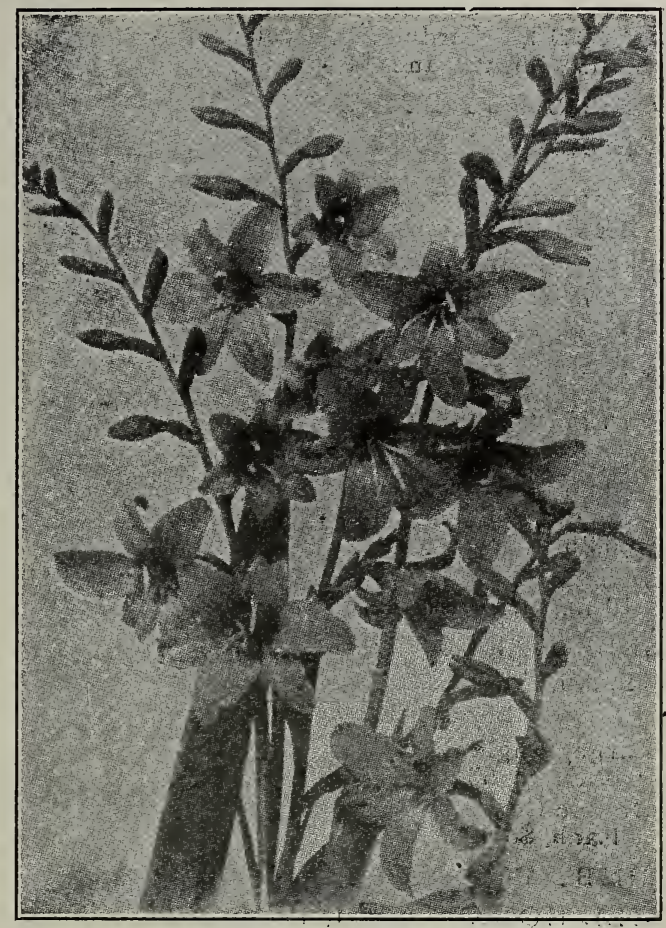

Montbretias.

Lasandria. Rosy-pink. cut foliage. .. $\quad .10 \quad .60$

Shamrock. Clover-like foliage; pink

flowers. ................... $.10 \quad .60$

Mixed Colors. Several varieties........

\section{P A E O N I ES.}

Indispensable in every garden; hardy and admirably adapted to northern climate, growing in almost all situations; even flourishing under shade trees.

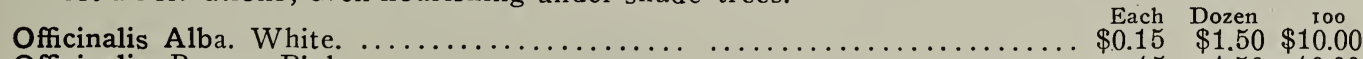

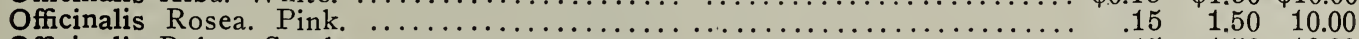

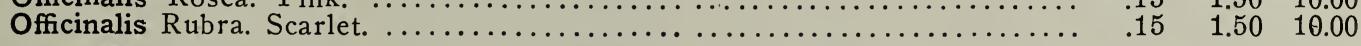

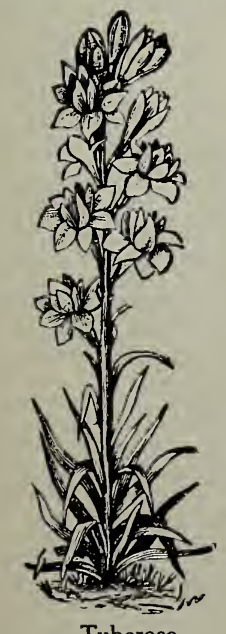

\section{TRIGIDIA (Shell Flower).}

Curious and beautiful shell-like flowers about four inches in diameter, flowering from July to October.

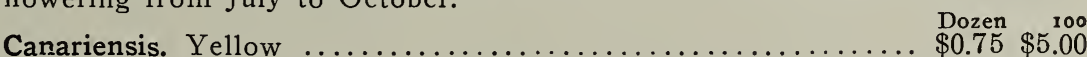

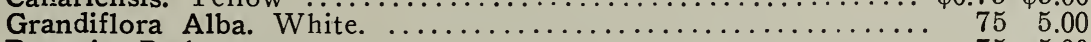

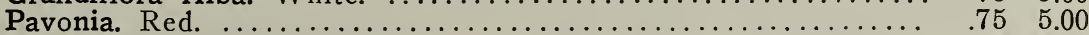

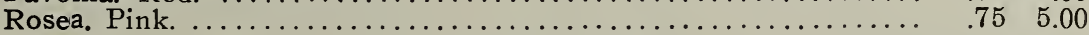

\section{T U B E R O S E S.}

One of the most popular summer-flowering bulbs.

Double Excelsior Pearl Extra fine bulbs...................... Dach Don ${ }^{\text {100 }}$ Armstrong's. The single ever-blooming Tuberose. ......... $\quad .05 \quad .50 \quad 3.50$

ZEPHYRANTHES. (Zephyr Flower, or Fairy Lilies).

Beautiful dwarf, bulbous plant; very effective for masses or borders: flowering with great profusion during the summer.

Candida. Pure white; very free-bloomer. ............. $\begin{aligned} & \text { Each } \\ & \$ 0.05\end{aligned} \stackrel{\text { Dozen }}{\$ 0.50} \$ 3.50$ Cardinalis. A large flowered cardinal red variety. ............ $\quad .50 \quad 5.0030 .00$ Tuberose. 


\section{HORTICULTURAL TOOLS AND REQUISITES.}

APRONS, Gardner's Rubber, Waterproof. Each, 75 cts. and $\$ 1.25$.

ASPARAGUS BUNCHER. Each, \$3.00. ASPARAGUS KNIVES, English. Each \$1:25. ASPARAGUS KNIVES, American. Each, 35c. AXES, FELLNG. With handle, $\$ 1.75$ to $\$ 2.50$.

BASKET, Galvanized, Round. No. 0, 3/4 bush. each $\$ 1.50 ;$ No. 1. 1 bush., $\$ 1.75 ;$ No. 2.2 bush., $\$ 2.25$.

BASKETS, HANGING, WIRE. Painted, 8 in., 20 c.; 10 in. 25 c.; 12 in., 35 c.; 15 in., 45 c.; 18 in., 65 c.; 20 in., 90 c. each.

BASKETS, ORCHID. 6 in., each 30c., dozen $\$ 3.25 ; 8$ in., each $40 \mathrm{c}$., dozen, $\$ 4.25 ; 10$ in., each 50 c., dozen $\$ 5.25 ; 12$ in., each 60 ., dozen $\$ 6.25$.

BASKETS, RUSTIC, HANGING. 8 in., $\$ 1.00$; 10 in., $\$ 1.2512$ in., $\$ 1.75 ; 14$ in., $\$ 2.25$ each.

BELLOWS, POWDER.

Small, Single Cone.

Each, \$1.50.

Large Single Cone. Each, $\$ 2.50$.

Double Cone. Each, \$3.50.
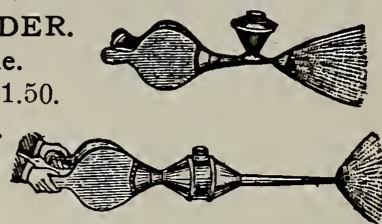

JUMBO POWDER. Each, $25 \mathrm{cts}$.

BILL HOOKS. Light, $\$ 1.25$; heavy, $\$ 1.50$.

BLAKE'S LEVER CLIPS. For fastening rose wire. Per $1,000, \$ 2.00$.

BOXES, Corrugated. Extra strong for shipping Cut Flowers.

\begin{tabular}{|c|c|c|c|c|}
\hline 24 in. & 8 in. & 4 in. & $\$ 2.25$ & $\$ 15.00$ \\
\hline 28 in. & 8 in. & 5 in. & 2.50 & 18.00 \\
\hline in. & 12 in. & $6 \mathrm{in}$. & 3.00 & 22.00 \\
\hline in. & 12 in. & 8 in. & 3.50 & 25.00 \\
\hline 8 & 14 & 8 in. & 4.50 & 33.0 \\
\hline
\end{tabular}

BOXES, FOLDING. For Cut Flowers. Made of strong cardboard.

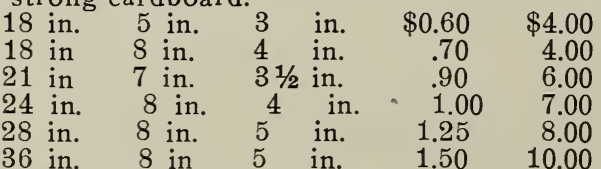

BROOMS, Birch. For lawns. Each 50c.

BRUSHES, or Flower Pot, Scrubbers. Made of coir fibre. Per dozen, $\$ 1.50$; each, $15 \mathrm{c}$.

BRUSHES, Flower Pot, Cone Shaped. Made of bristle. wood handle. Each, $75 \mathrm{c}$.

BRUSH HOOKS. Each, $\$ 1.25$ and $\$ 1.50$.

BRUSH HOOKS, English. Each, \$2.00.

CANES, BAMBOO.

Green, $21 / 2 \mathrm{ft} \quad \cdots \cdots \ldots$

Green $4 \quad \ldots \ldots \ldots \$ 0.10 \$ 0.60 \quad \$ 5.00$

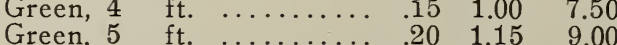

Natural, $6 \mathrm{ft} . \ldots \ldots \ldots \ldots \ldots . .10 \quad .75 \quad 7.00$

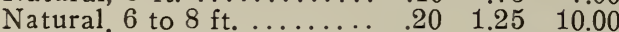

Japanese, Heavy, 8 ft..... $.30 \quad 2.00 \quad 15.00$

Japanese, Extra Heavy, 10 ft. $.40 \quad 3.00 \quad 25.00$

CARNATION STAPLES. For split Carnation.
CARNATION SUPPORT.

"Model Extension."

Wire, 2-ring...... \$0.50\$3.50

Wire, 3-ring........ .60 4.00

COCOANUT FIBER.

Useful for potting: Per bag, $\$ 2.00$. COTTON BATTING.

Large sheets. Dozen, 60c.

CORK BARK. Per lb., $15 \mathrm{c}$.

CULTIVATORS. (See page.81-82)

DAHLIA STAKES. (See page 73 ).

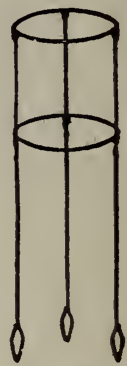

DIBBLES. Iron point, with wood handle for transplanting. Small, 35c.; large,

50 cts.

FLOWER POTS, STANDARD. Earthenware.

\begin{tabular}{|c|c|c|c|c|}
\hline & Each & Per & Per & Per \\
\hline $21 / 2$ in. & $\$ 0.01$ & $\begin{array}{r}\text { Doz } \\
\$ 0.10\end{array}$ & $\$ 0.90$ & $\begin{array}{l}1000 \\
\$ 8.50\end{array}$ \\
\hline 3 in. & .02 & .20 & 1.25 & 11.50 \\
\hline in. & .04 & .45 & 3.50 & 32.00 \\
\hline in. & .03 & .30 & 2.00 & 18.00 \\
\hline in. & .06 & .65 & 5.00 & 46.00 \\
\hline in. & .10 & 1.00 & 8.00 & 75.00 \\
\hline in. & .15 & 1.50 & 11.00 & 100.00 \\
\hline in. & .20 & 2.20 & 16.00 & $\cdots$ \\
\hline & .20 & 2.75 & 20.00 & \\
\hline & & & & \\
\hline
\end{tabular}

12 in. $\quad \begin{array}{llll}50 & 5.50 & 40.00 & \cdots\end{array}$

FLOWER POT SAUCERS. Earthenware.

Size Each Doz. Size Each Doz.

4 in. $\$ 0.03 \$ 0.25 \quad \begin{array}{r}\text { Size } \\ 5 \text { in. } \$ 0.09 \quad \$ 1.00\end{array}$

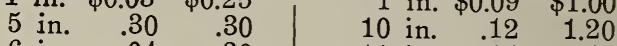

6 in. $.04 \quad .30 \quad 11$ in. $.14 \quad 1.40$

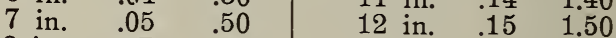

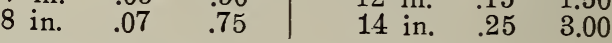

AZALEA POTS.

\begin{tabular}{|c|c|c|c|c|}
\hline $\begin{array}{l}\text { Wide } \\
5 \text { in. } \\
6 \text { in. } \\
7 \text { in. } \\
8 \text { in. }\end{array}$ & $\begin{array}{l}\text { Deep } \\
41 / 2 \text { in. } \\
5 \text { in. } \\
6 \text { in. } \\
7 \text { in. }\end{array}$ & $\begin{array}{r}\text { Each } \\
\$ 0.05 \\
.06 \\
.10 \\
.15\end{array}$ & $\begin{array}{c}\text { Dozen } \\
\$ 0.50 \\
.65 \\
1.00 \\
1.25\end{array}$ & $\begin{array}{r}100 \\
\$ 3.50 \\
5.00 \\
8.00 \\
11.00\end{array}$ \\
\hline
\end{tabular}

ROUND BULBS, or LILY PANS.

$\begin{array}{lllll}\text { Wide } & \text { Deep } & \text { Each } & \text { Dozen } & 100 \\ 6 \text { in. } & 3 \text { in. } & \$ 0.07 & \$ 0.70 & \$ 5.00\end{array}$

$\begin{array}{llrrr}7 \text { in. } & 31 / 2 \text { in. } & .08 & .80 & 7.00\end{array}$

8 in. 4 in. $\quad .10 \quad 1.00 \quad 8.00$

9 in. $41 / 2$ in. $\quad .15 \quad 1.50 \quad 12.00$

10 in. 5 in. $\quad .20 \quad 2.00 \quad 16.00$

12 in. 6 in. $\quad .35 \quad 3.50 \quad 27.00$

SEED PANS, Square Earthenware.

$6 \times 6$ in.......... Each, $\$ 0.30$ Dozen, $\$ 3.00$

$8 \times 8$ in...................... .35 Dozen, 3.50

$10 \times 10$ in.........Each, .40 Dozen, 4.00

$12 \times 12$ in...........Each, .45 Dozen, 4.50

HANGING FLOWER POTS. Earthenware.

Useful for growing hanging plants in the greenhouse or 'windows. 7 in., 25 cts.; 8 in. 30 cts.; 9 in., 35 cts.

FERN PANS. Earthenware. Outside measure. Width Height $\quad$ Each Dozen

43 in. $\quad 21 / 8$ in....... $\$ 0.05 \quad \$ 0.50$

$51 / 2$ in. $\quad 2 \frac{1 / 4}{1}$ in............ .06

$61 / 4$ in. $\quad 21 / 2$ in..............

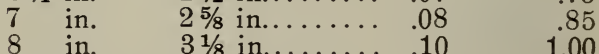

9 in. $\quad 31 / 4$ in.......... $12 \quad 1.25$ 


\section{HORTICULTURAL TOOLS AND REQUISITES (Continued)}

ORCHID PANS.

$\begin{array}{lr}\text { Each } & \text { Dozen } \\ 5 \text { in. } \$ 1.25 & \$ 8.00 \\ 6 \text { in. } 1.50 & 10.00 \\ 7 \text { in } 2.00 & 12.00\end{array}$

$\begin{array}{cr}\text { Each } & \text { Dozen } \\ 8 \text { in. } \$ 2.25 & \$ 15.00 \\ 10 \text { in. } 4.00 & 28.00\end{array}$

10 in. $4.00 \quad 28.00$
12 in 6.00

\section{NEPONSET WATERPROOF PAPER FLOWER POTS.}

Made of waterproof paper and are light, clean and unbreakable.

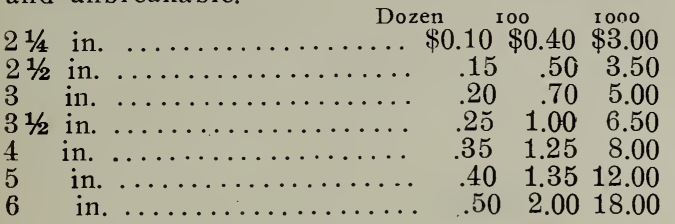

FLOWER POT SAUCERS.

Indurated Wood Fibre. Very light and durable. Not porous and will protect tables on which plants stand.

$\begin{array}{rrr}5 \text { in. } & \begin{array}{r}\text { Each } \\ 60.14\end{array} & \begin{array}{r}\text { Dozen } \\ \$ 1.60\end{array} \\ 6 \text { in. } & .15 & 1.70 \\ 7 \text { in. } & .17 & 1.80 \\ 8 \text { in. } & .18 & 2.00 \\ 10 \text { in. } \$ 0.20 & \$ 2.00\end{array}$

$\begin{array}{lrr}12 \text { in. } & \begin{array}{r}\text { Each } \\ .24\end{array} & \begin{array}{r}\text { Dozen } \\ 2.50\end{array} \\ 14 \text { in. } & .30 & 3.00 \\ 16 \text { in. } & .50 & 6.00 \\ 18 \text { in. } & .65 & 7.00\end{array}$

FLOWER POT ROLLING STANDS. For heavy plants. Platforms are indurated fibre ware; will not soak or rust. Casters have ballbearings.

Outside diam.

16 in. 4 casters

18 in. 4 casters

20 in. 4 casters

22 in. 5 casters

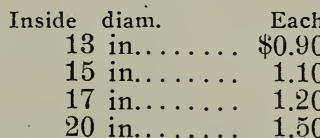

FLOWER VASES. Indurated Wood Fibre. Inside Measurement.

$\begin{array}{cccc}\text { No. Diameter } & \text { Deep } & \text { Each } & \text { Doz. } \\ 0 & 8 \text { in. } 13 \text { in. } \$ 0.75 & \$ 7.50\end{array}$

$15 \frac{1}{2}$ in. 10 in. $.65 \quad 6.50$

$24 \frac{1}{2}$ in. 9 in. $.55 \quad 5.50$

34 in. 6 in. $.50 \quad 5.00$

43 in. $4 \frac{1}{2}$ in. $\quad .40 \quad 4.00$

$00 \quad 9$ in. 22 in. $3.00 \quad 28.00$

017 in. 20 in. 1.5014 .50

$115 \frac{1 / 2}{1 n} 18$ in. $.75 \quad 7.50$

$224 \frac{1 / 2}{2}$ in. 15 in. $.65 \quad 6.50$
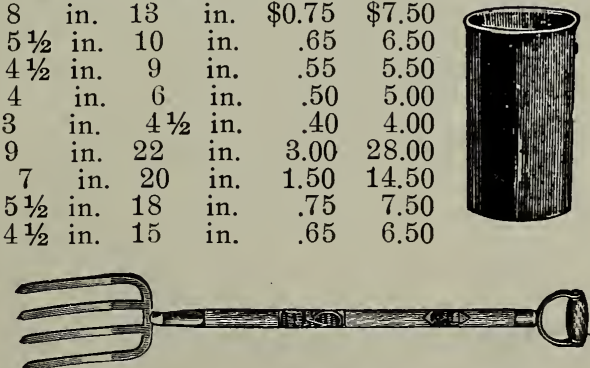

FORKS.

Digging or Spading. "Keen-Kutter."

4 Tine. Long or short handle. Each, $\$ 1.25$.

5 Tine. Long or short handle. Each, 1.50

Cast Steel. 4 Tine. Each, $\$ 1.00$.

Hay. 2 Tine, 75 cts.; 3 Tine, 85 cts.

Manure. Long and short handled, $\$ 1.00$.

Transplanting.

"Keen-Kutter."

Polished Steel.

Each, 70 cts.

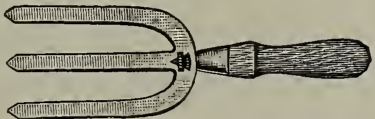

Trasplanting. Malleable. Each, 20 cts.
FRUIT PICKERS. Wire, "Peerless" 35 cts. FUMIGATOR, "EUREKA." For fumigating with Tobacco Stems. No. 2. Holds 1 peck stem..\$2.25 No. 3: Holds $1 / 2$ bush. stem. 2.75

FUMIGATING LAMP, “Defiance." For nicoticide, nicofume liquid, etc. No glass, burns kerosene oil. $60 \mathrm{c}$.

FUMIGATOR, SULPHUR. Campbell's Patent. Designed to vaporize Sulphur in greenhouses without danger of the Sulphur taking fire or disfiguring the foliage.

No. 1. For houses up to 5,000 cubic feet. Each, $\$ 6.50$

No. 2. For houses up to 10,000 cubic feet. Each. $\$ 8.00$.

FUMIGATOR, X. L. Lamp and stand complete. \$1.50. Glass lamps, separate. Each 35c. GARDNER'S GLOVES. Per pair, $\$ 1.25$.

GARDEN LINES. Finest braided hemp. 100 ft., 65 cts.; $200 \mathrm{ft}$., $\$ 1.25$.

GARDEN REELS, for above, of wrought iron Small, \$1.00; large, \$1.25.

GARDEN PENCILS. Indelible black. Each. 15 cts.

GLASS

CUTTERS.

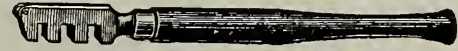

"Red Devil." No. 24, 10 cts.; No. 23, 15 cts.; No. 3.35 cts.; No. 6, 50 cts. each.

GLASS FOR GLAZING SASH. Market price "PEERLESS" GLAZING POINT. (Improved Van Reyper.)

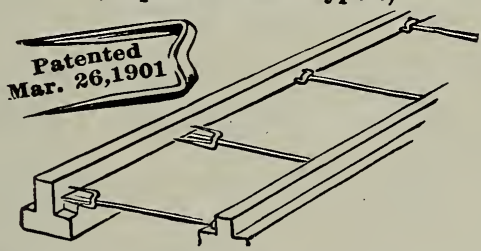

GLAZING POINTS, Peerless. Per 1,000, $75 \mathrm{c}$. PINCERS for above. Each, $50 \mathrm{cts}$.

GLAZING POINTS, Siebert's. Made of zinc and will not rust. Two sizes, $5 / 8$ and $7 / 8$ in. long. Per 1b., 40 cts.

GRAFTING WAX. For grafting cuts and bruises on trees. $1 / 4$ l'b., 10 cts.; $1 / 2$ lb., 15 cts.; 1 lb., 30 cts.

GRINDSTONES, Mounted. (See page 91).

GRASS EDGER "The Gates." A circular knife with long handle. Each, $\$ 1.00$.

\section{GRASS HOOKS \\ or SICKLES.}

Best English welded back.

No. 1. Small ....... Each, $\$ 0.50$

No. 2. Medium ..... Each, .75

No. 3. Large ....... Each, 1.75

German, small size.. Each, .35

German, large size... Each .50

GRAPE BAGS. Paper, plain, 40 cts. per 100; with wire, 50 cts. per $100 ; \$ 4.00$ per 1,000 .

HAMMERS. Garden, with claw. Each, 75 cts. HOES, DRAW. With handles. 5 in. 40 cts.; 6 in., 50 cts.; 7 in., 60 cts.; 8 in., 70 cts. 


\section{HORTICULTURAL TOOLS AND REQUISITES (Continued)}

HOES, SHUFFLE OR DUTCH.

Handles, 20 cts. extra.

4 in. $\$ 0.50 \mid 8$ in. $\$ 0.70$

5 in. $.55 \quad 9$ in.

6 in. $.60 \quad 10$ in.

7 in. $.65 \quad 12$ in.

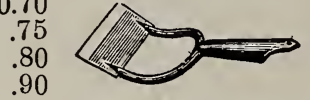

HOES, WARREN. Medium, 75 cts.; large, 90 cts.

HORSE BOOTS. For lawns; made of heavy leather: Medium size, set of four, $\$ 9.00$; large size, $\$ 10.00$.

HOSE BANDS. Made of brass wire. For putting on couplings. Per dozen, 15 cts.

HOSE PLIERS, for the above. Each, 25 cts.

HOSE CLAMPS. Bolt pattern. Dozen, $60 \mathrm{cts}$.

HOSE COUPLINGS. Brass. Each, 25 cts.

HOSE CONNECTION. Siamese. Each $\$ 1.00$

HOSE HOLDER. For holding the hose on lawns or borders. Each, 25 cts.

HOSE HYDRANT ATTACHMENT. Used for connecting hose to smooth faucets. Brass. Each, 50 cts.

\section{HOSE MENDERS.}

"Cooper's." Brass. $1 / 2$ or $3 / 4$ in., each, 10 cts., dozen, $\$ 1.00$.

"The Perfect Clinching" $3 / 4$ in., each 10 cts., dozen., $\$ 1.00$.

Jones' Iron. $3 / 4$ in., each 5 cts., doz., 50 cts.

HOSE NOZZLES.

"Gem," or "Graduating." $3 / 4$ in. hose. Can be regulated to give 3 different streams. Each. 50 cts.

"The Boss." Spray or stream, with shut-off. Each, 50 cts.

"The Stott." Single spray. Each, $\$ 1.25$.

"The Rainbow." (See cut). Fine or coarse spray. Each $\$ 1.50$.

"Hose Rose, or "Boston Spray." With coarse or fine spray, for $3 / 4$-in. hose. Each, 1 60 cts.

FERGUSON'S SPRAYER. Three roses. Each, $\$ 3.00$.

HOSE NOZZLES FOR SPRAY PUMPS.

"Bordeaux." Adjustable.

Each, 75 cts.

"Vermore 1." A fine spray. Each, 75 cts. "Shower." Will not clog and does the work without waste of material and time.

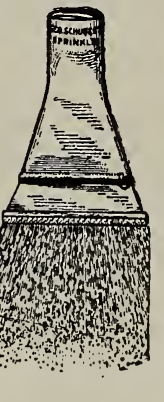

$1 / 4$-in. thread pipe. Each, $\$ 1.35$. (See cut).

Mystery, Jr. A fine spray. Each, $\$ 1.00$.

HOSE. RUBBER.

"Marshall" $1 / 2$ in. per foot. 16 cts. "Marshall" $3 / 4$ in. per foot. 18 cts. "Electric" $1 / 2$ in. per foot. 18 cts. "Electric" $3 / 4$ in. per foot. 20 cts. "Revero" $1 / 2$ in. per foot 18 cts. "Revero" 3/4 in. per foot 20 cts. Special Spray Pump $1 / 2$ in. per foot. 18 cts. HOSE WASHERS. $3 / 4$ in. doz. 10c.; 100,50 c.
HOES REELS. Made with tubular iron strong and durable.

No. 10 , for $100 \mathrm{ft}$., $3 / 4$-in. hose.

Each, \$3.25.

N.o. 20 , for $150 \mathrm{ft}$. $3 / 4$-in. hose. Each, \$3,50.

No. 30 , for $500 \mathrm{ft}$. $3 / 4$-in. hose. Each, $\$ 5.50$

Hose Reels. Wooden. Each, $\$ 1.50$.

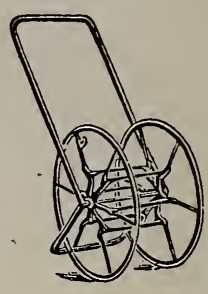

HYACINTH STAKES. Dyed green.

12 in. long. Per 100,20 cts.; $1,000, \$ 1.50$.

18 in. long. Per 100, 25 cts.; 1,000, 2.00 .

KNIVES, ASPARAGUS. American. Each, 35c.

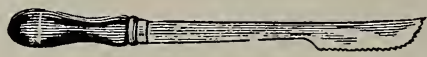

KNIVES, ASPARAGUS. English. Each, \$1.25. KNIVES, CORN. Forged steel. Each, 35c.

\section{KNIVES, BUDDING.}

Keen-Kutter.. Round point .........\$1.00

English. Round point. . . . . . . . . 1.50

English. Sharp point. ............... 1.50

English. Rourd point, brass cap. ..... 2.00

English. Sharp point, brass cap...... 2.00

Two Blades. Brass capped. .......... 1.50

\section{KNIVES. Pruning.}

American, in different shapes. Each, 75 cts. to $\$ 1.50$.

English, in different sizes. Each, $\$ 1.50$ to $\$ 2.25$.

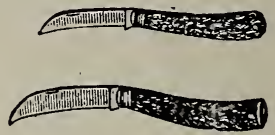

KNIVES, English Edging. Handles 20 cts. extra. 8-in., \$1.25; 9-in., $\$ 1.50 ; 10$-in., $\$ 1.75$.

American Edging. Each, 60 cts.

American Edging. With handles. Each, 75 cts.

The Gates Edger. A round revolving knife with long handle. Each, $\$ 1.00$. .

LABELS, Wooden. Pot and Garden.

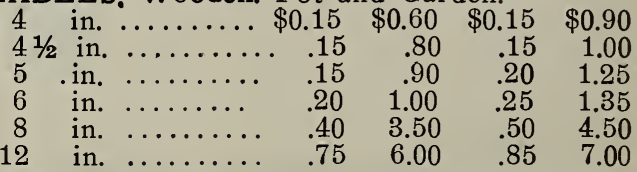

LABELS. Tree. Copper Wired. $31 / 2$ inches. Painted. Per 100, 25 cts.; 1000, $\$ 1.50$.

LABEL VARNISH Preserves wood labels; protects the markings; dries almost immediately. Applied by brush or dipping. Pint cans $80 \mathrm{c}$.

LABELS, Celluloid, Hanging. $31 / 4$ in. long, $7 / 8$ in. wide. Dozen, 20 cts.; $100, \$ 1.20$.

Celluloid. Pot. 5 in. long, $7 / 8$ in. wide. Dozen, 40 cts.; $100, \$ 2.50$.

LABELS, The Simplex. Waterproof.

No. 1. $3 x^{1 / 2}$ in., dozen, $\$ 0.25 ; 100, \$ 2.00$

N.o. 2. $4 \times 3 / 4$ in., dozen, $.50 ; 100,4.00$

No. 3. $5 \times 1$ in., dozen, .75; 100, 6.00 
LABELS.

"The A11 .proof.. Made with $\mathrm{z}$ i $\mathrm{n} \mathrm{c}$, h a v i n g a

white enameled surface for the name, which is covered with a glass slide.

Dozen Gross

No. 1 For hanging, $3 \frac{1}{2}$ in. long.. $\$ 0.60 \$ 6.50$

No. 2. For pots or borders, 6 in. long .60 6.00

No. 3. For pots or borders, 8 in. long. 707.50

\section{GLASS LABEL HOLDE:}

A permanent label air and water tight. Doz., 60c.; 100, \$4.00.

LABELS. Zinc Tree or Garden. Per 100, No. 1 , $\$ 2.00$; No. $2, \$ 1.75$; No. $5, \$ 1.75$; No. $6, \$ 1.50$; No. $7, \$ 1.25 ;$ No. $13, \$ 1.50 ;$ No. $15, \$ 1.25$; No. $21, \$ 1.75$.

INDELIBLE INK. For above. Per bottle, $25 \mathrm{c}$.

LADIES' TOOL SETS. Keen-Kutter, per set $\$ 2.00$.

LAWN SPRINKLERS. (See page 87).

LAWN RAKES. (See Rakes).

LAWN MOWERS. (See pages 83 to 85 ).

LAWN SWEEPERS. (See page 86).

LEAF-MOULD. Per peck, 30 cts.; 1 barrel bag, $\$ 1.75$.

LINES. (See Garden Lines).

MASTICA. For rglazing greenhouse. Per quart, 50 cts.; per gallon, $\$ 1.50$.

MASTICA GLAZING MACHINE. Each, $\$ 1.35$.

MATTOCKS

"Oak Leaf."

Hoe $4 \frac{1 / 4}{4}$ in

Cutter, 3 in.

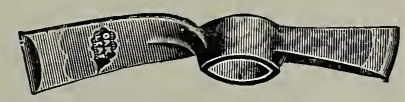

With handles, $\$ 1.35$

MATS, FROST-PROOF, COTTON

These mats are $76 \times 76$ inches square, and made of strong cotton cloth, filled with wool.

Each, $\$ 1.75$; per doz.,

$\$ 20.00$

WATERPROOF DUCK. Filled same as above with waterproof duck cotton cloth on one side. Size, $76 \times 76$ inches. Each, $\$ 2.25$; per dozen, $\$ 24.00$.

STRAW. Size, $6 x 6$ feet. $\$ 1.75$; per dozen, $\$ 20.00$.

MELON NETS. English make. Per doz., \$1.50.

MOLE TRAPS.

"New Model." Each, \$1.50.

"The Reddick." Each, \$1.00.

"English." Each, 35 cts.

MOSS, SPAGNUM, LIVE. For orchids. Per barrel, $\$ 3.00$.

For packing. Per 5-barrel bale, $\$ 3.00$ 10 -barrel bale, $\$ 4.50$.

Green, in sheets. Per bag, $\$ 5.00$.

Dyed Green, in sheets. Per bag, $\$ 5.00$.

NAILS. English Wall. $1 \frac{1}{2}$ inches. Per lb., 25 cts.

NOZZLES. See Hose Nozzles.

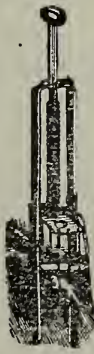

OIL CANS. Brass bottom. Three sizes, 30c. $40 \mathrm{c}$. and 50c. each.

PAPER, Cream Manilla. 24 x 36. Per 1b., 8c. Tissue. Per ream (480 sheets), $\$ 1.25$.

Waxed Tissue. Per ream ( 480 sheets), 24 x36 inches. $\$ 3.00$.

Coarse, for parcelling. Per lb., 8c.
AND REQUISITES (Continued)

PEAT. Rotted. Per 1-barrel bag, $\$ 2.00$.

Orchid. Per 1-barrel bag, $\$ 2.00$.

PENCILS, GARDEN. For labels. Each, $15 \mathrm{cts}$

PICK MATTOCKS. "Oak Leaf."

Hoe $4 \frac{1 / 4}{1}$ inches.

Pick $81 / 2$ inches.

With handles.

Each, \$1.25.

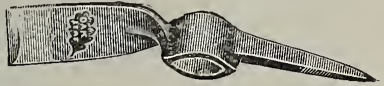

PICKS. Pointed both ends. With handles. Each, $\$ 1.00$.

PLANT SPRINKLERS. (See Sprinklers).

PLANT STAKES. Round Green Tapering (light).

$1 \frac{1}{2}$ feet. Each, $\$ 0.02$ Dozen, $\$ 0.20100, \$ 1.20$

2 feet. Each, .03 Dozen, .35 100, 2.00

$21 / 2$ feet. Each, .04 Dozen, $.40100,3.00$

3 feet. Each, .06 Dozen, $.60100,4.00$

$31 / 2$ feet. Each, .06 Dozen, $.60100,5.00$

4 feet. Each, .07 Dozen, .70 100, 5.50

Round Green Tapering (heavy).

4 feet. Each, $\$ 0.10$ Dozen, $\$ 1.00100 . \$ 7.50$

5 feet. Each, .12 Dozen, $1.30100,9.00$

6 feet. Each, .15 Dozen, 1.50 100, 11.00

Square Green Tapering (heavy).

4 feet. Each, $\$ 0.10$ Dozen, $\$ 1.00100, \$ 5.50$

5 feet. Each, .15 Dozen, $1.25100,7.50$

6 feet. Each, .20 Dozen, $1.50100,9.50$

BEAN POLES. Square, pointed, 8 feet long;

$1 \frac{1}{2}$ inch tapering to 1 inch at the top. Dozen, $\$ 2.00$.

DAHLIA POLES. Heavy. Round, green; tops painted white.

2 feet Each, \$0.06 Dozen, $\$ 0.60100, \$ 4.50$

3 feet. Each, .08 Dozen, .90 100, 6.50.

4 feet. Each, .10 Dozen, $1.10100,8.50$

5 feet. Each, .12 Dozen, $1.35100,10.50$

6 feet. Each, .15 Dozen, $1.65100,12.50$

GALVANIZED WIRE, for Roses, etc. Plain or Anchored. No. 9 Wire.

$21 / 2$ feet..........100, $\$ 1.25 \quad 1,000, \$ 10.00$

3 feet..........100, $1.301,000 \quad 11.00$

$31 / 2$ feet..........100, $1.501,000,13.00$

4 feet..........100, $1.75 \quad 1,000,15.00$

$4 \frac{1}{2} \quad$ feet...........100, $2.001,000,17.00$

PLANT PROTECTORS.: For Tomato or Egg plats; wire with cotton covering. Each, 25c.; dozen, $\$ 3.50$.

PLANT STANDS. Wire Folding. Made with wire shelves, with casters. 24 inches, 1 shelf, $\$ 2.00 ; 2$ shelves. 30 inches, $\$ 3.00 ; 3$ shelves, 30 inches, $\$ 4.00$.

PLANT STANDS. The Sabine adjustable, folding. Each $\$ 3.00$.

Drip Cups for the above, each 15 cts.

POTS. See Flower Pots page 70.

POT HANGERS. "Kraemers." Each 15 cts.; dozen $\$ 1.50$.

POTATO HOOKS. Broad flat prongs, 4 -prong 60 cts.; 5-prong, 75 cts.

POWDER DUSTER. For Slug shot. Each 35c.

POWDER GUN “Jumbo.” Each 25 cts. "Leggett's Little Giant." Each $\$ 6.00$.

"Leggett's Brownie." Each \$4.00.

PRUNER, Eagle Tree. $2 \mathrm{ft}$. handle. Each, $\$ 1.25 ; 3$ ft. handle, $\$ 1.50$.

Waters' Tree. $6 \mathrm{ft}$. handle, $90 \mathrm{c}$; $8 \mathrm{ft}$. handle, $\$ 1.00 ; 10 \mathrm{ft}$. handle, $\$ 1.15 ; 12 \mathrm{ft}$. handle, $\$ 1.25$ 


\section{HORTICULTURAL TOOLS AND REQUISITES (Continued)}

PRUNER or Lopping Shears.

"Keen Kutter"

Handles 21 in. $\$ 2.00$.

Handles 24 in., $\$ 2.50$.

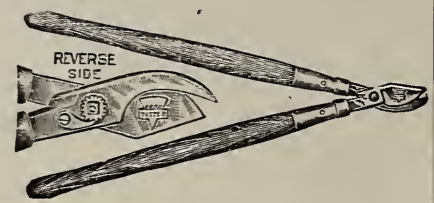

PRUNER. Rhode's Tree. Cuts on both sides and does not bruise the bark. Handles 20 or 26 inches long. Each $\$ 3.00$.

Little Giant Pruner, Hook and Saw Combined. A t taches to pole of any length. Each $\$ 2.00$.

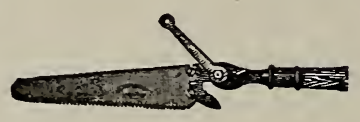

PROTECTING CLOTH. Valuable for protecting early plants from frost. Pieces contain from 40 to 60 yards.

Heavy Grade. Per yard, 16 cts.; by piece, per yard 15 cts.

Medium Grade. Per yard, 12 cts.; by piece, per yard $10 \mathrm{cts}$.

PUMP. "The Kinney." For distributing water and liquid manure through the hose at the same time. Each $\$ 2.50$.

PUMPS. (See Spray Pumps, pages 88, 89, 90.) PUTTY BULB, Rubber. For glazing, \$1.25.

PUTTY. Twemlow's Old English. One-gallon cans, $\$ 2.00$.

RAFFIA. The best material for tying plants. Per lb., 25 cts.; 5 lbs., $\$ 1.00$. Green, dyed. Per lb., 75 cts.

RAKES, GARDEN:

Best Steel, 8 teeth, 45 cts.; 10 teeth, 50 cts.; 12 teeth, 60 cts.; 14 teeth, 70 cts.; 16 teeth. 80 cts.; 18 teeth, 90 cts.

Hay, wooden, 3 bows, 12 teeth, 40 cts.

Lawn, wooden, 3 steel bows, 22 teeth, 55 cts.

Ladies' Wooden Lawn, 35 cts.

Reversible, Galvanized, 24 teeth, 50 cts.

Monarch Self-Cleaning. Galvanized Iron, Reversible, 24 teeth, 75 cts.

Lawn. "Olsen." 26 wood teeth, iron brace, 75 cts.

REELS, Garden. $\$ 1.00$ and $\$ 1.25$ each.

RIFLES, EMERY. For sharpening. Each, 15c.

ROLLERS. See page 86.

RUBBER ROOFING. For outhouses, sheds, etc. Made from Felt and Asphalt. 1-Ply, per roll of 108 square feet $\$ 2.25$. 2-Ply, $\$ 2.75$.

RUSTIC WORK. See page 77.

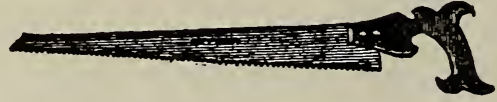

SAWS, Prunning. Single edge, 16 in., 75 cts.; 18 in., 90 cts.; 20 in., $\$ 1.00$. Double edge, 16 in., 85 cts.; 18 in., $\$ 1.00 ; 20$ in., $\$ 1.25$.

Double Swivel. Blade 14 inches long Very useful for pruning Each, $\$ 1.50$.

Oak Leaf. 14-inch blade which can be used at any angle. Each, $\$ 1.75$.

SAW FILES. Best make. Each, 10 cts.
SASH, Hotbed, Extra Strong, Unglazed. Made of best cypress, regular size. $3 \times 6 \mathrm{ft}$., using $6 \times \mathrm{x}$ in. glass. No. 4 Each, $\$ 1.50$; dozen, $\$ 16.00$.

Hotbed. Glazed. (Packing extra.) Size $3 \times 6 \mathrm{ft}$., using $6 \times 8$ in. glass. Painted two coats white. Each, $\$ 3.50$; dozen, $\$ 40.00$.

Hotbed, Glazed. Size $3 \mathrm{ft}$. 2 in. $x 6 \mathrm{ft}$. using $S \times 10$ glass. No. 9. Each $\$ 3.75$, dozen $\$ 42.00$

Hotbed, Glazed with $10 \times 12$ inch double thick glass.

Size $3 \times 6 \mathrm{ft}$. No. 10. Each, $\$ 4.00$; dozen, $\$ 45.00$.

"Sunlight." Double Glass. Glazed with $8 \times 10$ inch. double thick glass. Paint-

ed two coats, white. Each, $\$ 5.00$; doz., $\$ 5 \check{5} .00$.

HOTBED FRAMES, For Sash. For 2 sash, each, $\$ 8.00$; for 3 sash, each, $\$ 9.50$; for 4 sash, each $\$ 11.50$; for 5 sash, each, $\$ 13.50$.

SCISSORS, Grape or Vine. Best English. 6 in., $\$ 1.00$; 7 in., $\$ 1.25$; 8 in., $\$ 1.50$.

Flower Gatherers. Best quality. 6 in. $\$ 1.25 ; 7$ in., $\$ 1.50 ; 8$ in., $\$ 1.75$.

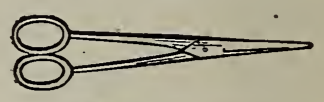

SCYTHES, Lawn English. 30 to 40 inches. Each, $\$ 1.75$ to $\$ 2.00$.

Lawn. German. 30 and 32 in. Each, $\$ 1.50$ Grass. American. 30 to 40 in. Each, $\$ 1.25$. Brush or Weed. 18 to 21 in. Each, $\$ 1.00$.

SCYTHE-SNATHS (or Handle). Each, $\$ 1.00$. SCYTHE-STONES. Round. Ea., 20.; doz., $\$ 2.00$.

S H E A R S, Grass

Border. English.

8 in..... $\$ 2.25$

9 in..... 2.50

10 in.... 3.00

\section{Grass or Sheep}

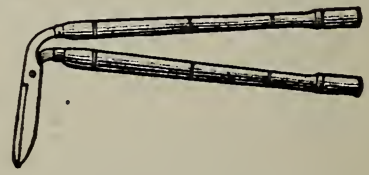

Best trowel shank. $\$ 1.00$.

Grasss, assorted sizes. Each, 25c., 50c., 75 c.

SHEARS, Hedge. Eng-

lish. (With notch, $25 \mathrm{c}$. in., $\$ 1.75 ; 10$ in., $\$ 2.00$.

Holdfast. Serrated Edge or Neverslip, 8 in. $\$ 1.75 ; 9$ in. $\$ 2.00 ; 10$ in. $\$ 2.50$.

Ridal's Patent. English, 9 in. $\$ 3.50$.

Ladies' Hedge. $5 \frac{1}{2}$ incehs, $\$ 1.50$.

SHEARS, Lopping. See Pruners.

SHEARS, Wiss, Hand Pruning. (Solid steel.) 9 in., $\$ 2.25 ; 10$ in., $\$ 2.50$.

California

Pattern. 9

in. 1 o $\mathrm{n} \mathrm{g}$

(see cut).

Each, 75c.

“Oak Leaf." 9 inches long. Each, \$1.00. 


\section{HORTICULTURAL TOOLS AND REQUISITES (Continued)}

PRUNING SHEARS.

Perfection Prun.ing. Cuts on both sides. $61 / 2$ in., $\$ 1.75 ; 71 / 2$ in., $\$ 2.00 ; 81 / 2$ in. $\$ 2.50$; $91 / 2$ in., $\$ 3.00$.

Watch Spring Pruning. 7 in., $\$ 1.75$; 8 in., $\$ 2.00 ; 9$ in., $\$ 2.50$.

Ladies' Pruning. $61 \frac{1}{2}$ in. Nickel plated, $\$ 1.00$.

SHREDS, Medicated Garded. For nailing on trees, vines, etc. 3 in, 30c. $100 ; 4$ in., 40c. 100.

SHOVELS. Best Cast Steel. Square and Diamond Pointed; long or short handles. Each, $\$ 1.25$ and $\$ 1.50$.

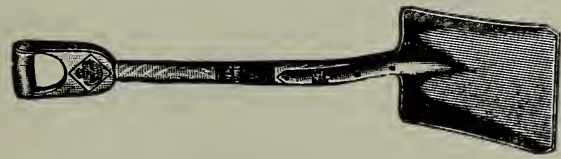

Good quality. Square or round pointed. Each $\$ 1.00$.

SIEVES, Wire. For sifting loam, gravel, etc., from 16 to 20 inches in diameter. Each, $\$ 1.25$ and $\$ 1: 50$.

SILKALINE, Meyer's Green. Fast color. Per spool, 25 cts.

Florist's Thread. 2 oz. spools, each, 15 cts.; dozen, $\$ 1.50$.

SMILAX TWINE. Green. Per box of 8 balls, $60 \mathrm{cts}$.

SPADES. Best Cast Steel. Long or short handles. Each, $\$ 1.25$ and $\$ 1.50$.

Good quality. Each, $\$ 1.00$.

SPRAYERS. See pages 88,89 and 90 .

SPRINKLERS, $R$ u b b e r. Scollay's straight or angle neck. No. 1, 12 oz. size. $\$ 1.00$.

The Ideal. Made entirely of metal and fits any bottle; can be used at any angle for insecticides or water. Each, 75 cts.

SPUDS. English. Each, 50 cts.

STAKES. See Plant Stakes and Canes.

Hyacinth. Green. 18 in. long. Doz., 5c.; 100 30 cts.

STICKS, Match. 18 in long. Per 1000. $\$ 1.50$

STYPTIC, Thompson's. To prevent bleeding of vines. Each $\$ 1.25$.

SULPHUR VAPORIZER, Campbell's Patent. See Fumigators page 71 .

SUMMER CLOUD. A well known English shading for Greenhouses or Frames. $1 / 2 \mathrm{lb}$. package, 30 cts.

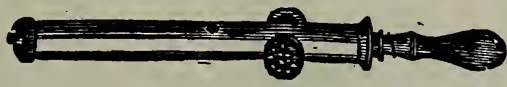

SYRINGES, Brass, Garden.

No. 2. Length $141 / 2$ in., diameter $13 / 8$ in., one spray rose and stream. Each, $\$ 4.00$.

No. 3. Length 18 in., diameter $1 \frac{112}{2}$ in.. two spray roses and one stream. Each, $\$ 5.50$.

No. 4. Length 18 in., diameter $1 \frac{1}{2}$ in. two spray roses and one stream extra heavy and strongly mounted. Each, $\$ 7.00$.

TENNIS NETS. Single court $27 \times 3 \mathrm{ft}$. Each, $\$ 1.25$. Double court $36 \times 3 \mathrm{ft}$., canvas bound. Each, $\$ 4.50$.
TENNIS MARKER. The Eureka. For marking. tennis courts. $\$ 10.00$.

THERMOMETERS.

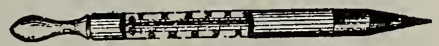

Mushroom Bed. Boxwood, brass tips. Each, $\$ 2.00$.

THERMOMETERS-Continuèd.

Distance Scale, metal frame.

Each, 50 cts.

Japan in tin case, 8 in., 35 cts.; 9 in. 45 cts.; 10 in., 60 cts.; 12 in., 70 cts.

Boxwood. Each, 75 cts., $\$ 1 . .00$ and $\$ 1.50$.

Maximum registering. Each, $\$ 2.75$.

Minimum registering. Each, $\$ 2.75$.

Porcelain Scale. For conservatory. Each, $\$ 1.50$.

Self-registering. Japanned

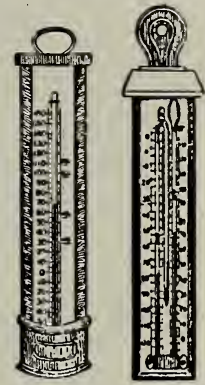

Case, 8 in. size, $\$ 3.50 ; 10$ in. size, $\$ 3.75 ; 12$ in. size, $\$ 4.25$.

Magnets for self-registering. Each $30 \mathrm{cts}$.

TIN FOIL. Per lb., 16 cts.; 100 lbs., $\$ 15.00$. Violet or Green. Per 1b., 50 cts.

TOOL SETS. "Keene-Kutter." Fork, spade, hoe and rake. per set $\$ 2.00$.

TOOTH PICKS. Wired. Per 1000, 30 cts.

T O R C H E S, Asbestos.

Each, 35 cts. Handles 15 cts. extra.

TOMATO SUPPORTS

Wire. Each, 20 cents dozen, \$2.00.

Perfection. Wood. Each 30 cts.; dozen, $\$ 3.00$.

TREE CLIMBERS. For attaching to the legs, tc climb tall trees. Pe1 pair. $\$ 3.50$.

TREE GUARDS. "Anchor" Expanded Metal. Very strong, steel wire, with three iron supports. Each, $\$ 3.00$.

TREE SCRAPERS. Large

iron with handle. Each, $75 \mathrm{cts}$.

\section{TREE BRUSHES.}

For removing parasitic growths and insects from trees and cleaning greenhouse benches, floors and woodwork.

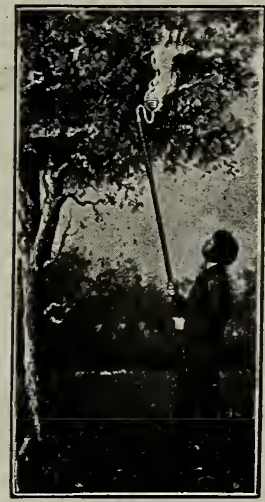

No. 150. The best tree brush for all purposes. Each, $\$ 2.50$.

No. 160. For big trees. Handle 24 inches long. Each, $\$ 2.00$.

No. 161. Made to fasten to handle for cleaning old trees. Each, $\$ 2.50$.

No. 161 A. For cleaning trees. Handle 16 inches long. Each, $\$ 1.50$.

No. 162. With handle 7 inches long for cleaning branches and trees. Each, $\$ 2.00$. 


\section{HORTICULTURAL TOOLS AND REQUISITES (Continued)}

TROWELS.

Steel. 6 in., 45 c.; 7

in., $50 . ; 8$ in., $55 \mathrm{c}$.

Cast Steel. Each, 25 cts.

"Keen Kutter." Best forged steel, 6-inch. blade bent or straight neck. Each, 75 cts.

Cleve's Angle. Large size. Each 25 cts.

Primrose. Iron. Each, 10 cts.

TUBS. Plant. See page 80.

TURFING IRONS. English. Eạch, $\$ 4.00$.

TWINE. Green Smilax. Per box, 8 balls, 60 cts.

Marline. (Tarred Twine). Per lb., 25 cts.

Marline. Small size. Per lb. 50 cts.

Hemp. All sizes. Per 1 b., 35 cts. to 40 cts.

Jute. Three or four-ply, for trees. Per lb., 25 cts.

WEEDERS. "Excelsior." Each, 10 cts.

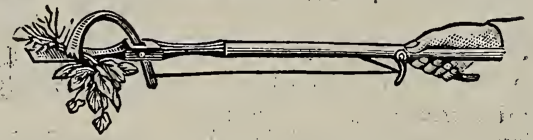

"Cleveland." Can be used easily and without stooping. Each, 70 cts.

"Adjustable."

Thre e Prong.

See cut. Each,

40 cts.

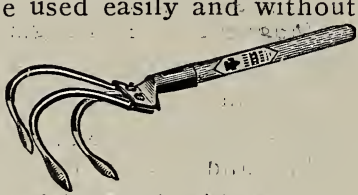

Daisy Grubber. English. Each, $\$ 1.00$.

Dandelion Puller. Long or short handle. 60c.

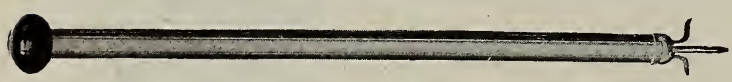

"Erado" Weed Killer. Used for dropping gasoline in the heart of weeds, also has cutter. Solid brass. Each \$1.25.

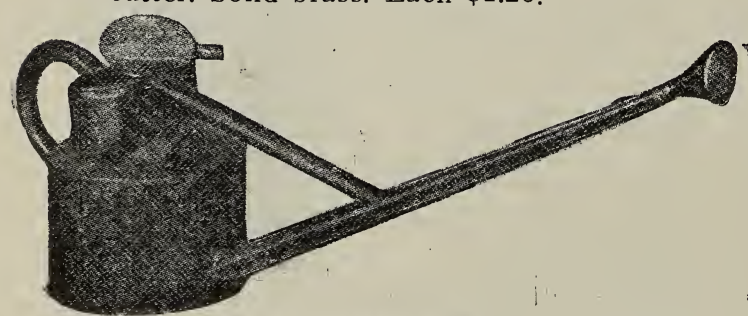

Hawe's English Watering Pot.

French Pattern. With long spout and brass bow handle, 6 quarts, $\$ 2.50 ; 8$ quarts, $\$ 2.75$; 10 quarts, $\$ 3.25$.

Philadelphia Pattern. With two copper-faced roses. 4 qts., $\$ 2.00$; 6 qts., $\$ 2.25$; 8 qts., $\$ 2.35 ; 10$ qts, $\$ 2.50 ; 12$ qts., $\$ 2.75$.

Extra Roses. Fine or coarse. Each, 35 cts.

\section{ROCO WOOD GRIP GALVANIZED}

WATERING POT: This watering pot has a wood grip handle, which is a great advantage for carrying purposes. It is made with heavy galvanized material. 4 quarts, $50 \mathrm{cts}$; 8 quarts. 70 cts.; 10 quarts, 90 cts.; 12 quarts, $\$ 1.10,46$ quarts, $\$ 1.30$

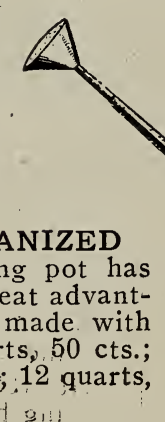

\section{WEEDERS. Continued.}

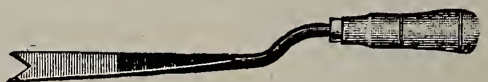

Lawn. For removing docks, dandelion, etc.; can also be used as an asparagus knife. $35 \mathrm{c}$. "Eureka." Very useful for garden purposes. Each, 35 cts.

Thistle Spud. English. Each, 50 cts.

The "Dandy-Lion" Weed Killer. With brass covered cylinder, brass ball handle, removable base, valve, spring, etc. Each $\$ 1.00$.

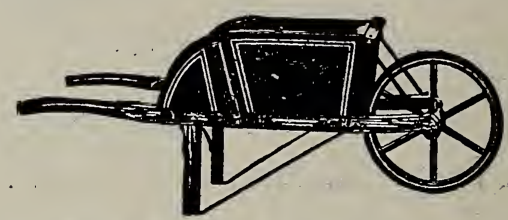

WHEELBARROWS, Garden. Small size No. 3. $\$ 3.50$ Medium size No. 4. Each, $\$ 4.00$. Large size N.o. こ. Each, $\$ 4.50$.

WINDOW BOXES. Self Watering. Made with heavy metal, ornamented with a stamped design. They require water only every two weeks and will not leak. All sizes are 8 inches high and $9 \frac{1 / 2}{2}$ inches wide. No. 1, 23 in. long, $\$ 2.30$. No. 2,25 in. long, $\$ 2.50$. No. 3.27 in. long, $\$ 2.70$. No. 4,29 in. long, $\$ 2.90$. No. 5 , 31 in. long, $\$ 3.10$. No. 6, 33 in. long, $\$ 3.30$. No. 7, 35 in. long, $\$ 3.50$. No. 8, 37 in. long, $\$ 3.70$. No. 9, 39 in. long, $\$ 3.90$. No. 10,41 in. long, $\$ 4.10$.

WIRE Annealed, for Stemming. 12 or $18 \mathrm{in}$. lengths.

No. 23. Coarse, per 1b. ........ 20 cts.

No. 26. 'Coarse, per lb. ......... 25 cts.

No. 34. Fine Hair, per lb. ....... 30 cts.

\section{WATERING POTS.}

Hawe's English. Valuable for watering fine seeds, as well as for all greenhouse and garden work. One very fine and one coarse rose. Made with heavy material, painted red. 6 quarts, $\$ 3.50 ; 8$ quarts, $\$ 4.00 ; 10$ quarts, $\$ 4.50$. 
RUSTIC CHAIRS, VASES, ETC.

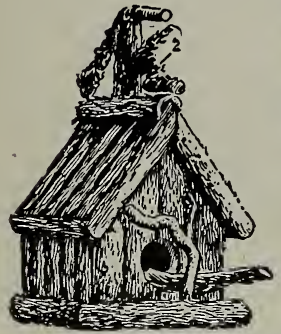

Bird House.

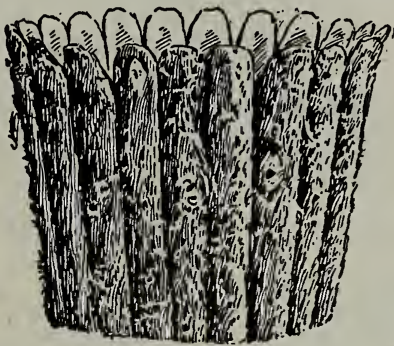

Rustic Stump Tub.

RUSTIC BIRD HOUSE. Very ornamental.

Each, $\$ 1.25, \$ 1.75, \$ 2.75$ and $\$ 3.25$

RUSTIC STUMP TUB. Adapted for tree stumps, terraces or porches. Each, 17-in. tub., $\$ 2.00$.

RUSTIC GARDEN VASES. Made of red cedar, unpeeled. Very ornamentat, for Lawns when filled with plants. Each, 12 -inch tub, $\$ 4.00 ; 16$-inch tub, $\$ 5.00$.

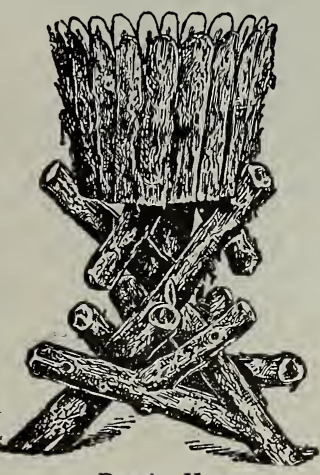

Rustic Vase.

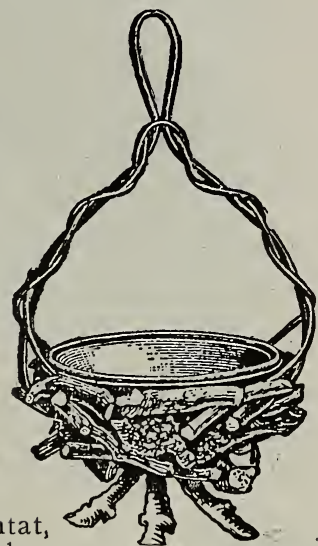

Hanging Basket.

RUSTIC CEDAR CHAIRS. Strong, durable and ornamental. Each, $\$ 6.00$. Extra heavy, $\$ 8.00$

RUSTIC HANGING BASKETS. Made from Laurel Roots; elegantly finished and rattan handle. These baskets cannot be equaled in style; finish or make. They will stand severe weather, and with a little care are good for 10 or 12 years' wear. Each, 10 -inch, $\$ 1.35 ; 12$-inch, $\$ 1.50$; 13 -inch, $\$ 1.75 ; 14$-inch, $\$ 2.00$.

RUSTIC WINDOW BOX. Made of Chestnut or Cedar, unpeeled. Extra strong and durable. Outside measurement 22 inches, $\$ 1.10 ; 28$ inches, $\$ 1.25 ; 32$ inches, $\$ 1.50 ; 36$ inches, $\$ 1.65$ each.

RUSTIC PORCH BOXES. 18 inches square. Each, $\$ 1.10$ :

RUSTIC CEDAR SETTEES. Made strong and ornamental. Each, $\$ 9.00$. Extra heavy, $\$ 11.00$

RUSTIC CEDAR TABLES, Round. Adapted for Summer Houses or Lawn. 30 inches diameter Plain top, each, $\$ 6.00$. 'Cedar top, $\$ 8.00$.

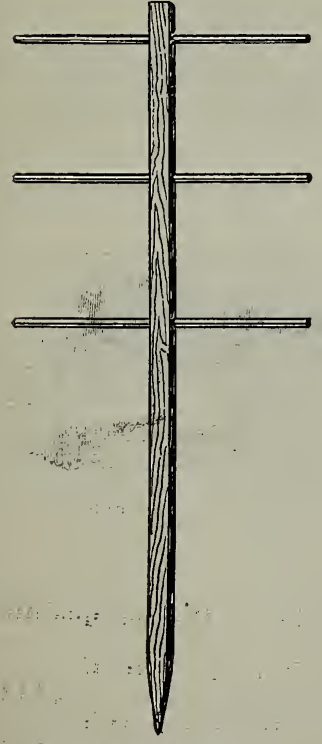

Single Support.
We shall be pleased to give prices for Rustic Summer Houses Bridges or other work upon application.

\section{SINGLE BERRY SUPPORT.}

Can be used for all kinds of Shrubbery. Made of $2 \times 2$ inch hard wood. Posts, 6 feet high and arms 4 feet across. Painted green. Very strong and durable. Each, 40 cts ; dozen, $\$ 4.00$.

\section{DOUBLE GRAPE AND SHRUBBERY SUPPORT.}

Made of $2 \times 2$ inch hard wood Posts 6 feet high and arms 4 feet across. Painted green. Ornamental and useful for any vines. Each, $\$ 1.00$; dozen, $\$ 10.00$.

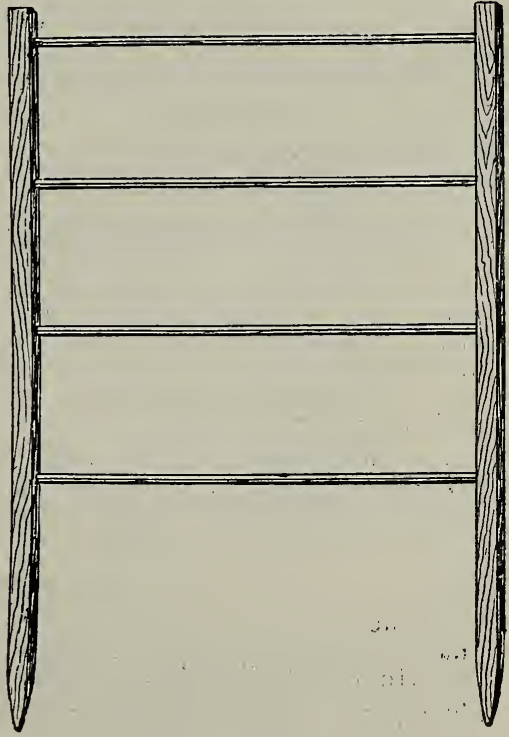

Double Support.

\section{HARDWOOD BEAN POLES.}

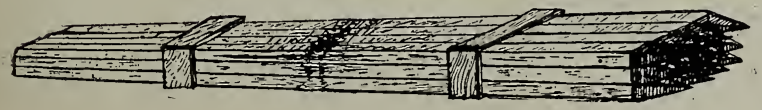

Made from hard wood. Eight feet long Pointed to drive in the ground. 11/2 inches square and tapering to one inch at the top. Each, 20 cts.; dozen, $\$ 2.00$. 


\section{COMBINATION WATER BARREL TRUCK AND LEAF CART.}

Barrel can be detached from truck without difficulty, or tilted to empty contents. Either barrel, leaf rack and box can be used.

TRUCK AND WATER BARREL.

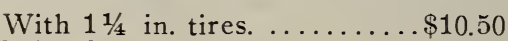

With 3 in. tires. $\ldots \ldots \ldots \ldots, 12.50$

TRUCK AND HANDCART BOX.

With $11 \frac{1}{4}$ in. tires. ........ $\$ 11.00$

With 3 in. tires. .......... 13.25

TRUCK AND LEAF RACK.

With $11 / 4$ in. tires. ......... $\$ 13.00$

With 3 in. tires. $\ldots \ldots \ldots \ldots \ldots 15.25$

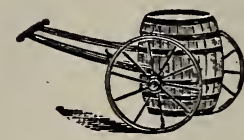

Water Barrel.

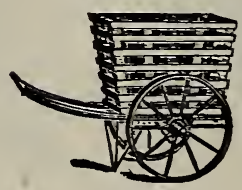

Leaf Cart.
TRUCK, BARREL. LEAF RACK AND CART.

Complete with $1 \frac{1 / 4}{4}$ in. tires... $\$ 21.50$ Complete with 3 in. tires.. 23.00

ADDITIONAL ATTACHMENTS.

Box for Hand Cart. $\$ 1.00$.

Leaf Rack for Truck. $\$ 6.00$.

Sprinkling Attachment. $\$ 1.50$.

Extra Barrels with Trunnions. $\$ 4.00$.

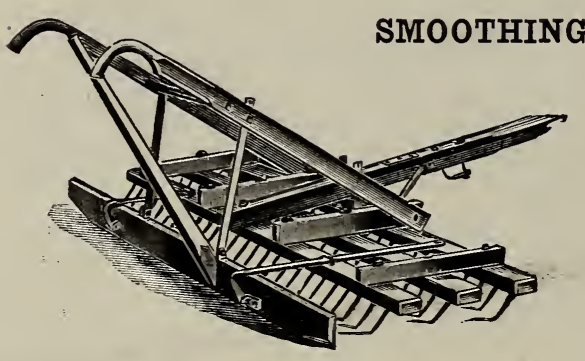

AND LEVELING HARROW.

With this tool every field can be made as smooth as a floor and the soil pulverized fine enough for a flower bed-makes a mast perfect onion bed.

This harrow is also a great road maker. One man, with team, can make a perfect trotting track of any road. It is adjustable with a lever, by which the entire action is controlled by the driver, and he can remove at will all the earth possible for the team to haul, taking it from hills or uneven places and putting it into hollows to level up the field.

One-horse, $6 \mathrm{ft}$., $\$ 14.50$; two-horse, $\mathrm{S} \mathrm{ft}$., $\$ 16.50$.

\section{GARDENER'S HARROW.}

Designed for one horse, convenient to handle and get around garden plots, etc.

25 Teeth, with Runners. ................... \$7.00

30 Teeth, with Runners. ..................... $\$ .00$

\section{“STEVENS" FERTILIZER DISTRIBUTOR.}

This machine in addition to plaster will sow Bonedust, Ashes, Lime, and all fine fertilizers. It broadcasts evenly any quantity desired from 200 pounds to 4,000 pounds per acre. The adjustment is perfect, simple and strong. Combined Pole and Shafts, Neck Yoke and Whiffletrees iurnished with each machine.

Machine to sow to a width of 8 feet 3 inches..... $\$ 55.00$

Machine to sow to a width of 5 feet 10 inches..... 47.00

Hand Fertilizer Distributor, 34 inches wide..... 15.00

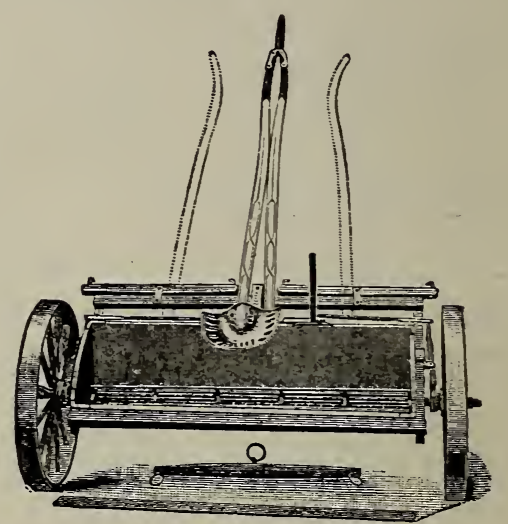

"Steven's" Feitilizer Distrrbutor.

\section{S TEEL B E A M I O W S.}

These are new patterns, and intended for general purpose, having superior turning qualities, make them well adapted to sandy and.stony soil.

No. 83. Medium Two Horse Plow, will turn a furrow 5 to 7 inches deep by 11 to 13

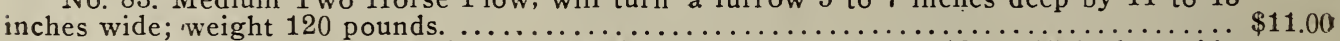

No. 84. Large Two Horse Plow, turns 5 to 8 inches deep by 12 to 15 inches wide; weight 125 pounds. ...................................................... 11.50

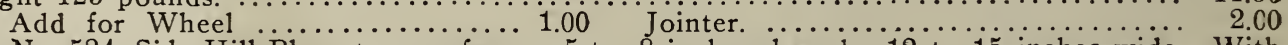

No. 524. Side Hill Plow, turns a furrow 5 to 8 inches deep by 12 to 15 inches wide. With Chilled Mould, \$11.50; with Steel Mould, \$13.50 Add for Wheel, \$1.00. Hanging Coulter, \$2.00.

\section{ONE HORSE GARDEN PLOW.}

No. 6. Iron beam wood handles; cuts a 3 to 6 -inch deep furrow, and 7 to 10 inches wide. Weight, 63 pounds. Price, with extra point. $\$ 7.00$; with wheel, $\$ 1.00$ extra. 
GRINDING MILL.

This machine will grind dry bones. shells or grain, either fine or coarse. It will make excellent grit out of old crockery, melted glass, etc.

No. 1 , without legs $\$ 5.00$; No. 1 , with legs, $\$ 7.00$.

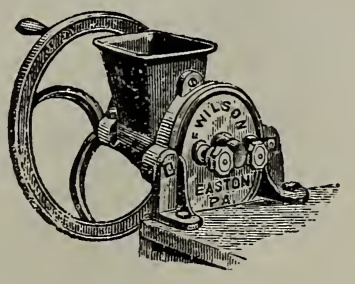

HAND CORN PLANTERS.

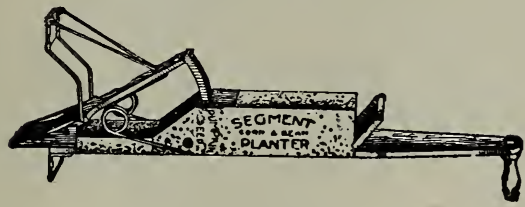

"SEGMENT"

Is light, strong, accurate and withal the cheapest and most up-to-date Planter on the market. Price, $\$ 1.50$.

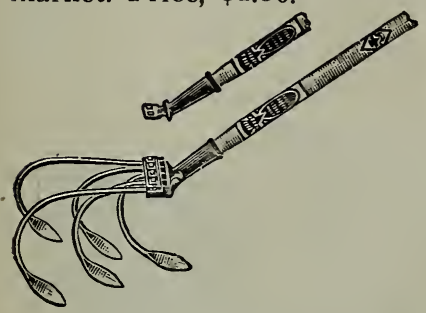

GARLAND FLOWER GUARD.

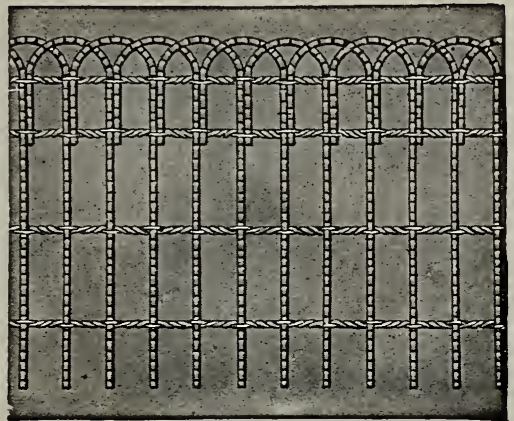

This guard is made from No. 9 and No. 12 wire, galvanized after weaving. Made to stand 12 and 18 inches above the ground after being set in place. The end pickets extend 4 inches below the lower cable to set in the ground.

16 inches wide, per foot. ..........\$0.18

22 inches wide, per foot ........... .20

Rolls of 165 feet, 18 inches, 16 cts, per foot; 22 inches, 18 cts. per foot.

\section{ADJUSTABLE GARDEN CULTIVATOR.}

The most useful hand garden tool on the market.

It will pull out the weeds, pulverize the ground thoroughly, leaving it level. It will work between the rows or the center shovel can be removed, and straddle the row if desired. It is adjustable in width by sliding the top plate. It is the lightest, weighing but 3 pound complete, with long handle. The blades are forged out of a solid steel rod. Price $\$ 1.00$.

POST HOLE DIGGER.

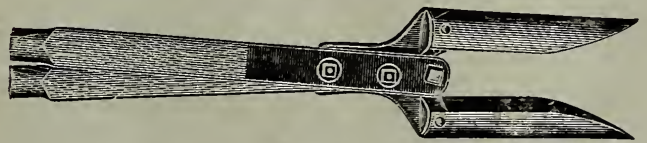

The blades are 9 inches long, and the handles 5 feet long

Price ...............\$1.00

\section{PERFECTION TOMATO SUPPORT.}

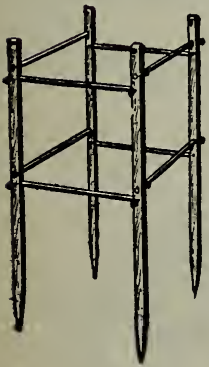

This is the most practical support on the market. It is made of wood and will not burn the vines in hot weather, or cut them off when swayed by the wind.

The height is 36 inches and the width 16 inches. It can be unfolded after use without damage and stored away for the following season.

$$
\text { Each, } 30 \text { cts.; dozen, } \$ 2.50 \text {. }
$$

\section{WIRE TOMATO SUPPORT.}

Made with heavy wire, three legs and forming two rings.

Each, 20 cts.; dozen, $\$ 2.00$.

\section{FERGUSON'S COMBINATION SPRAYER AND SYRINGE.}

Three roses-fine, medium and corse. Recommended for syringing under the foliage of plants where force is needed to keep down red spider, etc.

Made of brass, and screwed on the end of any hose. $\$ 3.00$.

\section{"UNIQUE" , HEDGE TRIMMER}

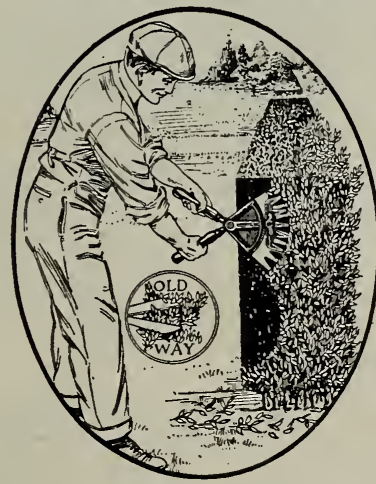

Great time saver for clipping hedges. They lay flat on the hedge, assuring an even trimming and cut on both motions like a horse clipper.

Price, $\$ 4.00$.

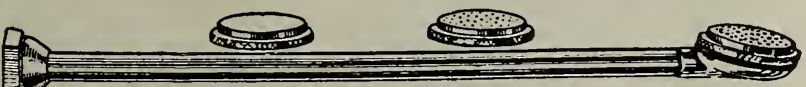




\section{TOLEDO PLANT TUBS}

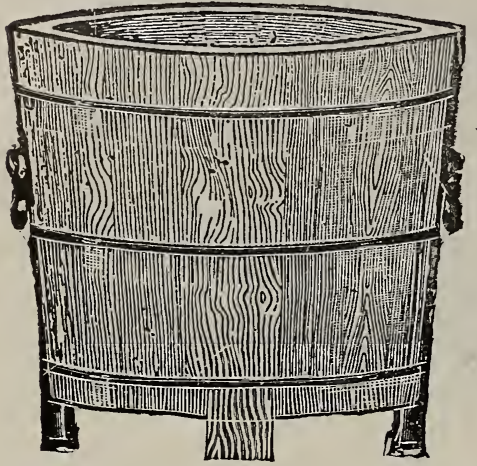

Have galvanized electric welded wire hoops. It is very essential that plant tubs be provided with feet, so as to keep the damp tub from resting on the floor or carpet, and to prevent rot and decay. Tub made of the everlasting red cedar, painted green.

Nos. A, B, C and D are furnished without handles.

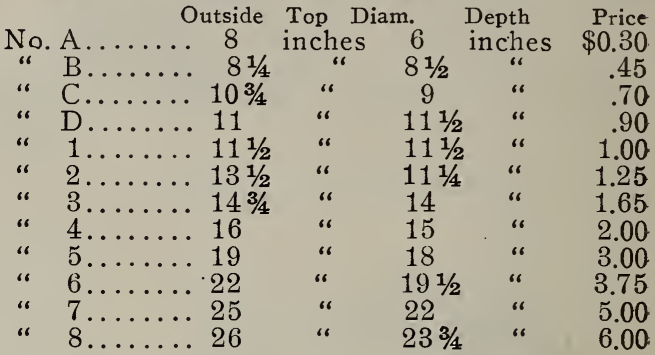

\section{CEDAR TREE TUBS.}

Very heavy cedar. Painted green in regular stock. Any color desired to order.

No. $1 \ldots \ldots \ldots 28$ inches 22 inches $\$ 5.50 \mid$ No. $6 \ldots \ldots \ldots 181 / 2$ inches 15 inches $\$ 3.00$

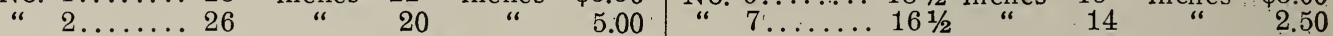

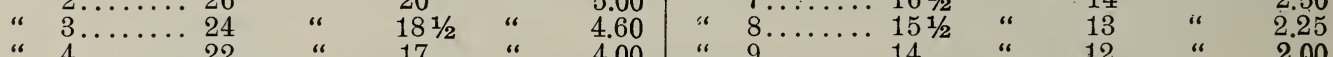

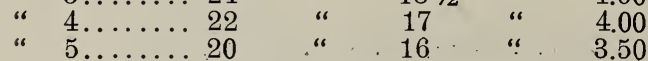

SUMIMER CLOUD SHADING.

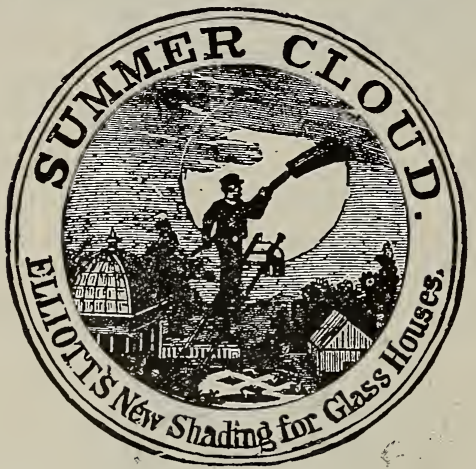

This well known English preparation is used for shading Greenhouses, frames, etc. Does not wash off like lime. Packages containing 8 ounces. Each, 30 cts.

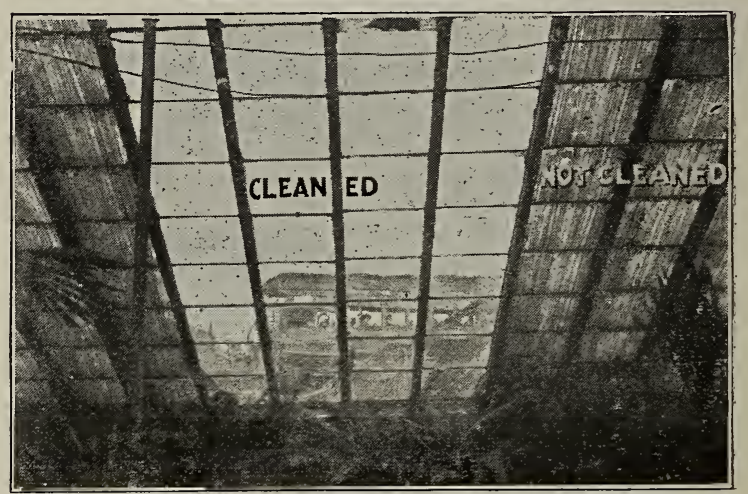

This will clean shading or other dirt from glass without injury to paint or putty. Valuable for cleaning sides or roofs of greenhouses.

Per gallon, $\$ 1.25$; 5 gallons, $\$ 5.00$.

\section{THE “MARSHALL” GARDEN HOSE.}

We have arranged with a leading maker to manufacture a special hose for garden and greenhouse work which is non-kinkable and will stand the highest water pressure.

Sample mailed on request. In 25 and 50 feet lengths only with $3 / 4$-inch connections.

"Marshall" Hose. $3 / 4$ inch, 18 cts. per foot; $1 / 2$ inch, 16 cts per foot.

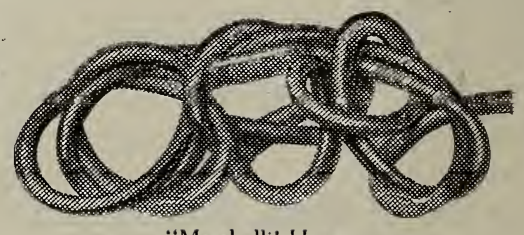

\section{G A R D E H O S E.}

"Extra." Seven Ply Hose. 3/4 in. Per ft, 15 c. "Special." Five Ply Hose. $3 / 4$ in. Per-ft., $12 \mathrm{c}$. "Special." Four Ply Hose. 1/2 in. Per ft., 10c. "Electric." Non-kinkable. $3 / 4$ in. Per ft., 20c.
"Electric." Non-kinkable. $1 / 2$ in. Per ft., $18 \mathrm{c}$ "Revero." Non-kinkable. $3 / 4$ in. Per ft., 20 c. "Revero." Non-kinkable. $1 / 2$ in. Per ft., 18c. "Special." Spray Hose. $1 / 2$ in. Per ft., 18c. 


\section{PLANET JR. TOOLS - Continued}

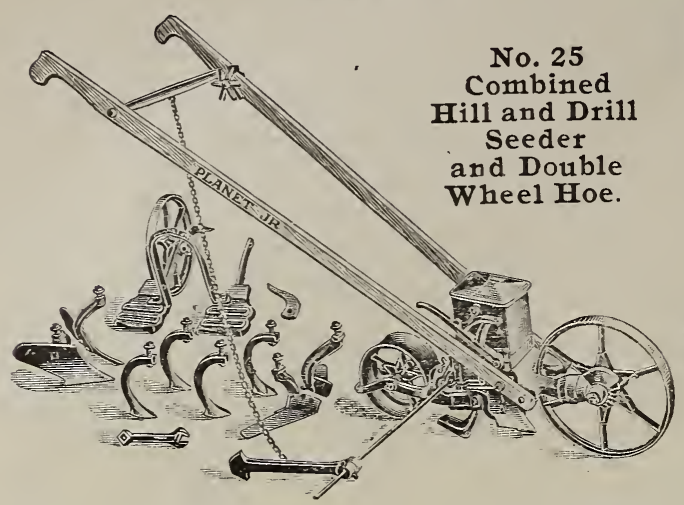

Price, complete...$\ldots \ldots \ldots \ldots \ldots \ldots \$ 13.50$

As a seeder it will sow in drills any thickness or drop in hills $4,6,8,12$ or 24 inches apart. It is thoroughly substantial and is accurate in planting all kinds of garden seeds in either hills or drills.

As a wheel hoe it is practically the same as the admirable Planet Jr. No. 12 Double Wheel Hoe, Cultivator and Plow.

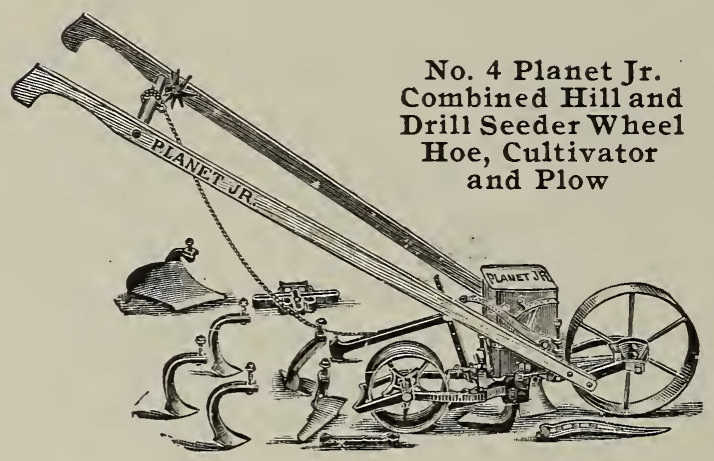

Price, complete ............\$11.00

As a Seeder only .............. 9.00

Does the work of almost all garden tools combined. It sows accurately all garden seeds in drills or in hills $4,6,8,12$ or 24 inches apart, cultivates, furrows and plows.

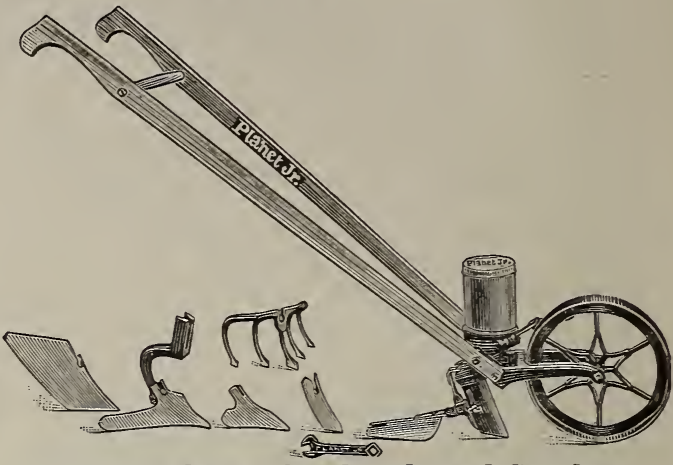

No. 31 Planet. Jr. Combined Seeder and Wheel Hoe.

It combines a thoroughly reliable Seeder that will sow all garden seeds from the smallest up to peas and beans with a first-class light running Wheel Hoe. A very practical tool for all gardeners.

No. 31 Complete Seeder and Wheel Hoe

Price $\$ 7.00$

No. 32 As a Seeder only. Price $\$ 5.00$

No. 33 as a Wheel only. $\quad$ Price $\$ 3.00$

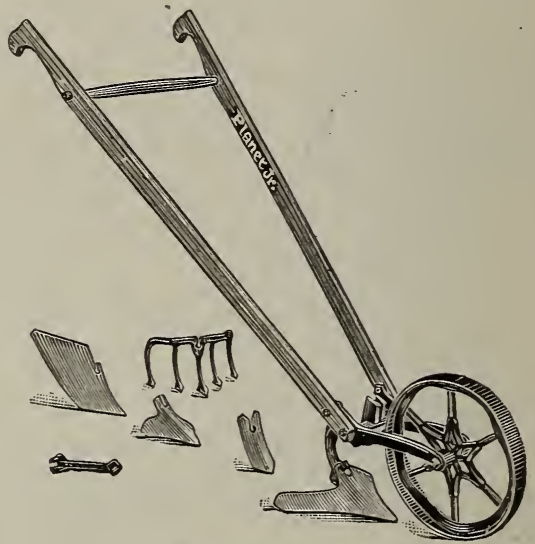

No. 104. Horse Hoe \& Cultivator

Equiempnt: five 3 in. Steels, 1 pair 6 in. turning shovels one 7 in shovel steel and lever wheel. Price $\$ 7.00$.

\section{DOUBLE HOPPER WHEELBARROW SEEDER.}

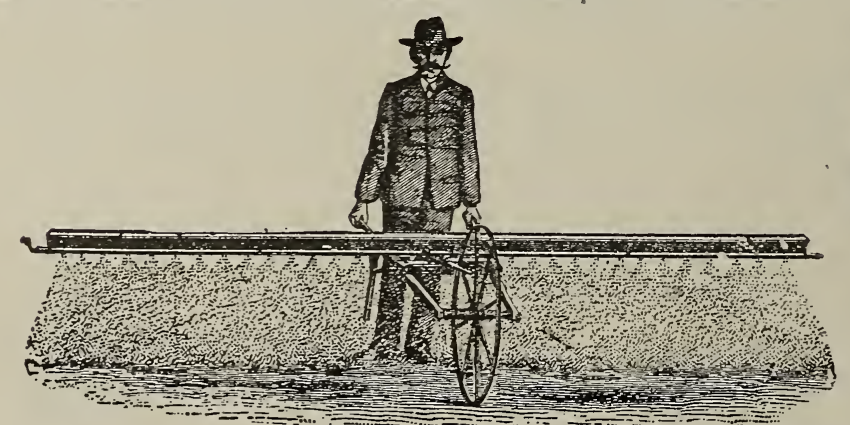

This seeder will sow grass seeds as well as heavy seeds of all kinds. It can be regulated to sow any quantity per acre the whole length (I4 feet) of the hopper and it does not clog up. Full directions with each seeder. Price \$II.00.
CAHOON'S BROADCAST SEED SOWER

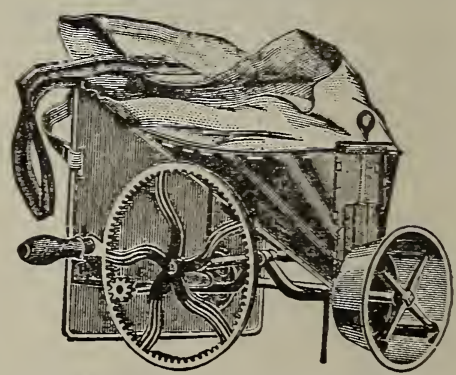

This machine will sow Wheat, Rye, Oats, Barley, Hemp, imothy, Clover, Millet and Hungarian Seed, throwing from eight to twenty feet on each side of the operator. $\$ 3.50$. 


\section{COLDWELL'S LAWN MOWERS.}

\section{IMPROVED EXCELSIOR MOWER.}

This mower is made to meet the demand for a machine that will more perfectly cut borders. verges, etc., and yet retain all the other features necessary in a mower for general work.

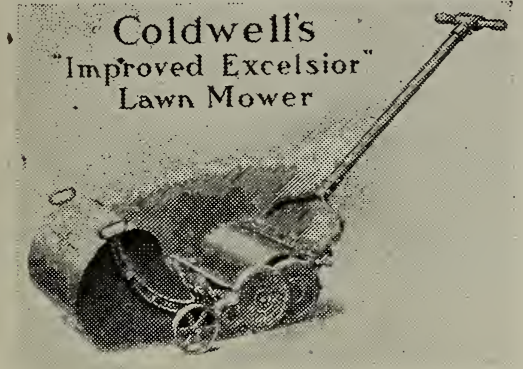

Net Price, 12 inches, 4 blades. . $\$ 11.00 ; 6$ blades. $\$ 11.50$

Net Price, 14 inches, 4 blades.. 12.50; 6 blades.. 13.00

Net Price, 16 inches, 4 blades.. 13.50; 6 blades.. 14.00

Net Price, 18 inches, 4 blades.. 15.00; 6 blades.. 16.00

\section{CHAIN ROLLER GOLF MOWER.}

Net Price, 12 inches, 4 blades. . $\$ 10.50 ; 6$ blades. . $\$ 11.50$

Net Price, 14 inches, 4 blades.. 12.00; 6 blades.. 13.00

Net Price, 16 inches, 4 blades.. 13.00; 6 blades.. 14.00

Net Price, 18 inches, 4 blades. . 15.00; 6 blades. . 16.00

\section{IMPERIAL HIGH WHEEL MOWER.}

The Imperial is one of our best Mowers. It can be sharpened in a few minutes without removing any of its parts. We positively guarantee this Mower to give entire satisfaction.

Net Price, 14 inches, 4 blades....\$ $9.00 ; 5$ blades....\$ 9.50

Net Price, 16 inches. 4 blades... . 10.00; 5 blades... . 10.00

Net Price, 18 inches, 4 blades. . . 11.00; 5 blades.... 11.50

Net Price, 20 inches, 4 blades.... 13.00; 5 blades.... 13.50

\section{“THE RAJAH” BALL-BEARING LAWN MOWER.}

The "Rajah" is the best Ball-Bearing Mower on the market. I has 10-inch drive wheels; five blades in the revolving cutter, which is of large diameter, thus enabling it to cut high grass. The adjustment of this machine is accomplished by means of a single screw conveniently located in the end of revolving cutter. This one screw does it all.

Net Price, 14 inches..........\$ 9.00

Net Price, 16 inches............ 10.00

Net Price, 18 inches..........\$11.00

Net Price, 20 inches............ 12.00

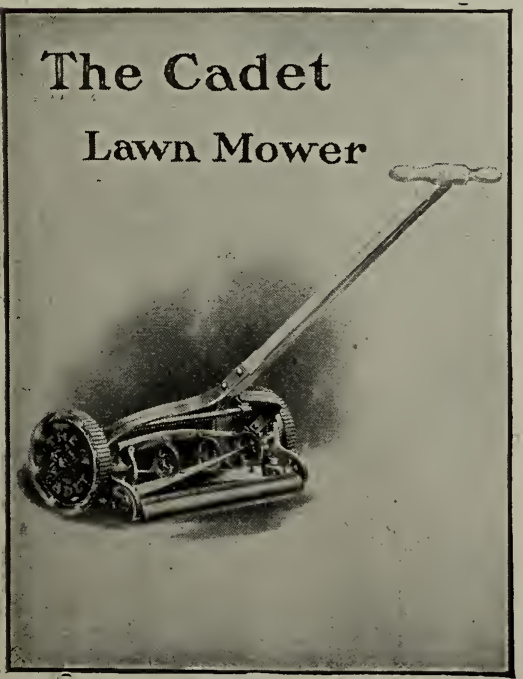

"THE REGAL" BALL-BEARING LAWN MOWER.

The drive wheels of the "Regal" are locked fast to the opposite ends of a steel shaft which is supported near its ends by all bearings. The ball bearings are fitted with adjustable cones, by means of which the wheels can always be made to run true, no matter how much the machine is worn.

Net Prices: 14 inches, $\$ 10.50 ; 16$ inches, $\$ 11.50$ 18 inches, $\$ 12.50 ; 20$ inches, $\$ 13.50$.

\section{GRASS CATCHERS.}

Net Prices:

12 inches, $\$ 1.50 ; 14$ inches, $\$ 1.60 ; 16$ inches, $\$ 1.85$; 18 inches, $\$ 2.00 ; 20$ inches, $\$ 2.15$.

\section{THE “CADET” LAWN MOWER.}

This mower is made by the Coldwell Lawn Mower Co. for the benefit of those who want a cheap mower and those who have but a little grass to cut. It is a very strong and durable machine, and will be found far superior to the mower usually sold in "department stores" at the same prices.

Prices, Net: 12 in., $\$ 3.50 ; 14$ in., $\$ 3.75 ; 16$ in., $\$ 4.00$ 


\section{TOWNSEND'S LAWN MOWERS. \\ THE "TOWNSEND" HORSE LAWN MOWER.}

The most perfectly constructed Horse Lawn Mower on the market. Triple rolls with triple pawls in each roll. Unlike other mowers, the motion of the blades is maintained even when turning sharp corners. The height of cut and motion of knives is under perfect control of the driver from his seat, and the large rolls (15 inches in diameter) insure great power and ease of movement.

Pony Mower, 25-inch cut...... Net, $\$ 50.00$

Horse Mower, 30 -inch cut........Net, 68.00

Horse Mower, 35-inch cut...... Net, $\$ 80.00$

Horse Mower, 38-inch cut........ Net, 90.00

\section{TOWNSEND'S TRIPLEX HORSE LAWN MOWER.}

The Triplex Mower consists of three Mowers yoked together, two abreast in front, and one in the rear, thus cutting a swath 86 inches wide.

One man and one horse, with a Triplex, will cut more grass in a day than with three ordinary Horse Mowers. Ask for Catalogue with full particulars. Price $\$ 250.00$ net. F. O. B. Orange, N. J.

\section{"VICTORY" BALL-BEARING LAWN MOWER.}

This mower is fitted with Ball-Bearings. The gear is entirely closed, so that no dirt or cut grass can find its way into the pinions and clog them. The cutter bar is easily removed for sharpening without disturbing the frame. The knives cut the instant the mower is moved. 14 Net Prices:

16 inches.......... $11.00 \quad 22$ inches.......... 14.00

18 inches.................... 12.0015 .00

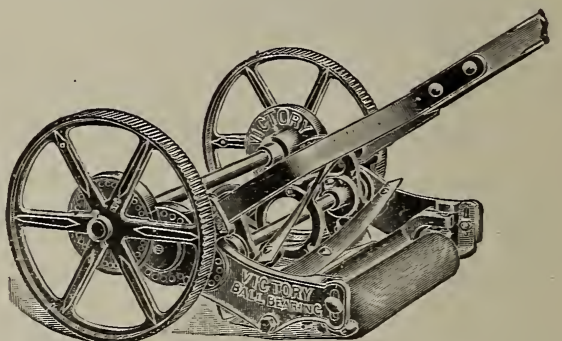

" ORANGE'” BALL-BEARING MOWER.

This is a good all-around mower; 10-inch wheels; four blades 2 gear drive.

12 inches.. Net $\$ 8.00 \quad 16$ inches.. Net $\$ 10.0020$ inches.. Net $\$ 12.00$

14 inches.. Net 9.0018 inches.. Net 11.0022 inches.. Net 13.00

TOWNSEND'S GOLF WONDER MOWER.

Especially designed for cutting Putting Greens and fine Lawns. Runs very easy. due to high speed, has gear drive and six blade knife reel. 16 in. $\$ 18.00 ; 18$ in. $\$ 20.00 ; 20$ in. $\$ 22.00$. Grass Catcher $\$ 3.00$.

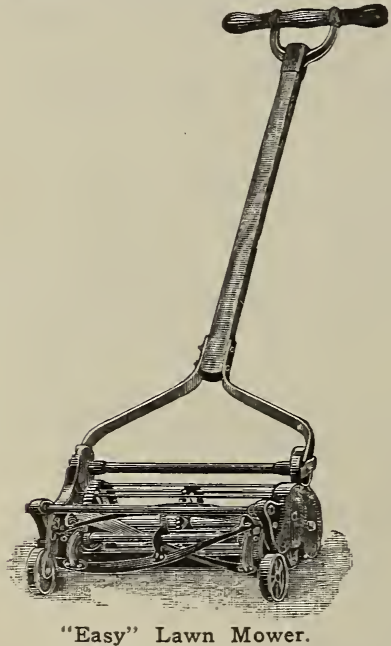

\section{PENNSYLVANIA LAWN MOWERS.}

Low wheel, 8-inch diameter.

12 inches, 3 blades......\$10.00 16 inches, 4 blades..... $\$ 12.00$

14 inches, 4 blades....... $11.00 \quad 18$ incehs, 4 blades...... 13.00

High wheel, $101 / 2$-inch diameter.

15 inches, 4 blades...... $\$ 15.00 \quad 19$ inches, 4 blades..... $\$ 17.00$

17 inches, 4 blades...... $16.00 \quad 21$ inches, 4 blades...... 18.00

\section{“EASY" BORDER LAWN MOWER.}

The only Mower made that will cut Borders, Mounds, Terraces, close to Walls and Fences, and all kinds of uneven surfaces with the same ease and efficiency as the smoothest lawn.

It has a steel open roller, four spiral blades, self adjusting ball bearings with detachable handle.

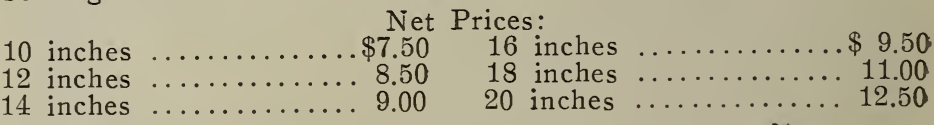

THE “CLIPPER” MOWER.

The cut shows a perspective view of the "Clipper" Mower. In the first place you will observe the cutter bar is directly in front of the wheels. The wheels travel over ground where the grass is cut, never rolling down the standing grass with the wheels, as other Lawn Mowers do. 'The small gauge wheels at the side are to gauge the height you wish to cut the grass.

Net Prices: 15 inches, $\$ 8.00 ; 18$ inches, $\$ 8.50 ; 24$ inches, $\$ 9.00$

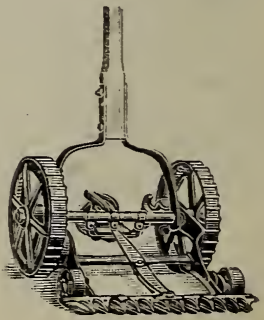




\section{COLDWELL'S COMBINATION ROLLER AND IMOTOR LAWN MOVER}

This machine is designed for use on small estates, tennis grounds, etc. It cuts a swarth 40 inches wide, is equipped with a 2 horse power motor, capable of propelling the mower through almost any height of lawn grass and up grades as steep as $25 \%$. It is also equipped with Coldwell's patented demountable cutting unit. This device is an extra cutter composed of the knives and parts to carry them, which can be removed from the machine in a few moments and replaced by the other unit. It is also equipped with a new patented device for raising the knives when crossing gravel walks, roads, etc., thus protecting them from injury. Clutches are provided to throw the traction rollers, as well as the revolving cutters in and out of gear.

Price, including Extra 'Cutter Unit, Style F, \$475.00.

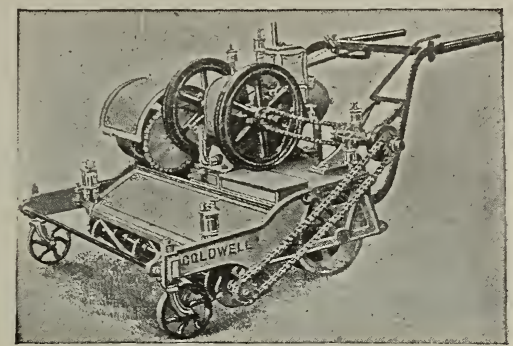

\section{F. O. B. Factory.}

\section{THE COLDWELL MOTOR LAWN MOWER.}

Weight, 2,000 pounds. Equipped with 2-cylinder, 4-cycle, latest improved automobile motor Consumes three-fourths of a gallon of gasolene per hour; cuts 40 -inch swath. Guaranteed to negotiate 25 per cent. grades Cutting part can be lifted from the ground by means of a single lever. $\quad$ Style D, $\$ 1300.00$. Net F. O. B. Factory, Newburgh, N. Y.

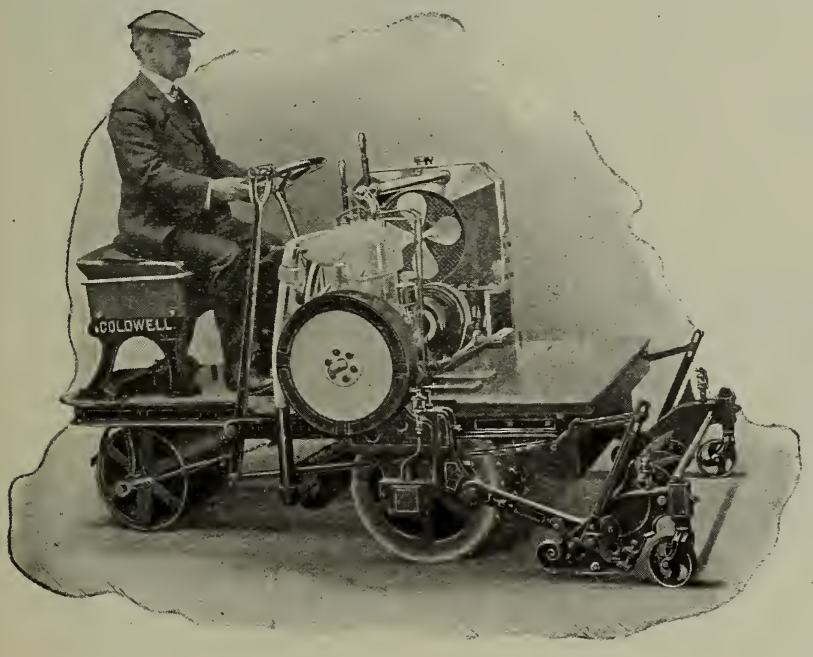

\section{COLDWELL'S DEMOUNTABLE HORSE LAWN MOWER.}

The Demountable Cutter Unit Horse Mower is constructed upon an entirely new principle and is a wide departure from anything of the kind ever made. The cutter section, which is the vital part of a lawn mower, is made into a unit and is independent and removable from the main frame of the mower. This unit consists of a simple frame containing the revolving cutter, the bottom or stationary knife and parts necessary for adjusting the same to each other. It is attached to the main frame of the mower by four locking screws and can be attached or removed in less than a minute.

This unit, being the cutter section of the mower, is the only part necessary to send in to the factory for sharpening or adjusting.

Net Prices: 30 inches, $\$ 100.00$; 35 inches, $\$ 125$; 40 inches, $\$ 150.000$.

These prices include an extra cutting unit.

\section{COLDWELL'S IMPROVED}

\section{HORSE LAWN IMOWER.}

It has side draft attachment to enable the horse to walk on the cut only. We secure evenness of cut by an adjustment which raises or lowers the two sides at the same time by means of a simple lever movement; the same lever serves the purpose of raising the knifes from the ground when driving over gravel walks or roads.

Net Prices:

30. inches, 4 blades.......\$ 65.00

30 inches, 6 blades........ 71.00

35 inches, 4 blades........ 80.00

35 inches, 6 blades........ 86.00

40 inches, 4 blades........ 95.00

40 inches, 6 blades....... 101.00

\section{" UTICA" LAWN TRIMIMER.}

'Cuts every blade of grass left by a lawn mower close to fences, trees, flower beds, etc. Knives keen edged with a 5-inch cut. Can be used with one hand and does better work in one third the time it would

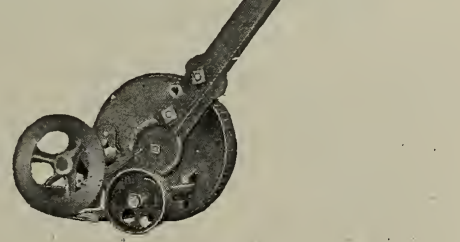

take with shears or grass hooks Price, $\$ 3.50$. 


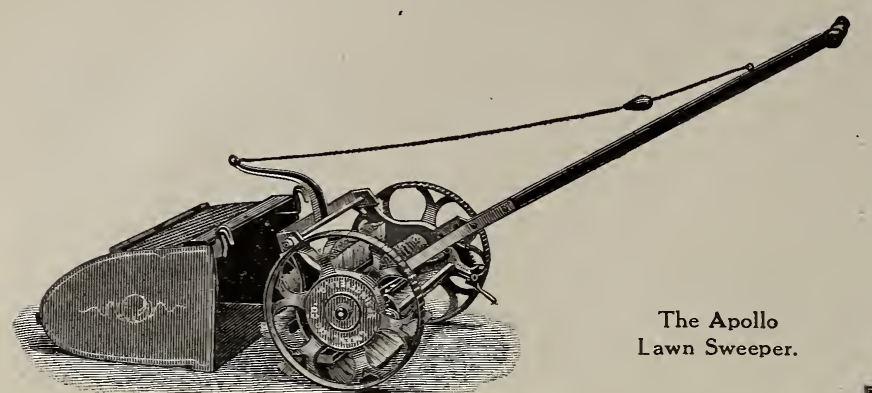

PENNSYLVANIA GEIM LAWN CLEANER.

A revolving fan with metal teeth creates an air current which carries in to the canvas baskets all leaves, dead grass, stone, etc., that the rake encounters. It straightens up crab grass and other running weeds so that they may be cut by lawn mower. It combines strength and durability with light construction. 24 inches wide. Price, $\$ 17.00$.

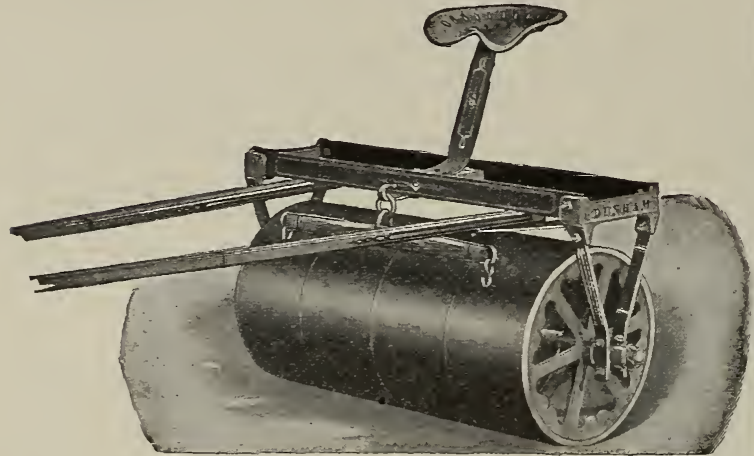

\section{GOLD MEDAL HORSE LAWN AND GOLF GROUND ROLLERS.}

All steel frame and brackets, axle lathe turned heavy machine steel. Rollers smooth face, aluminum finished and outer edges rounded.

\begin{tabular}{lcccrr} 
No. & Sects. & Diam. & Width & \multicolumn{1}{c}{$\begin{array}{c}\text { Weight } \\
\text { lbs. }\end{array}$} & \multicolumn{1}{c}{ Price } \\
440. & 3 & 24 in. & 30 in. & 650 & $\$ 43.00$ \\
441. & 4 & 24 in. & 40 in. & 800 & 52.00 \\
442. & 5 & 24 in. & 50 in. & 950 & 61.00 \\
443. & 3 & 28 in. & 30 in. & 800 & 52.00 \\
444. & 4 & 28 in. & 400 in. & 1000 & 64.00 \\
445. & 5 & 28 in. & 50 in. & 1200 & 76.00
\end{tabular}

\section{GOLD MEDAL ROLLER BEARING LAWN ROLLER.}

These Rollers are smooth on face and rounded on outer edge to avoid cutting the lawn. Roller Bearings make them $40 \%$ easier to operate than the old style Roller. Write for descriptive circular.

No. 402

No. 404

No. 407

No. 409 .

No. 411 .

Diameter

15 inches

20 inches

20 inches

24 inches

24 inches

24 inches

\section{Length}

24 inches in 3 sections 20 inches in 2 sections 24 inches in 3 sections 20 inches in 2 sections 24 inches in 3 sections 30 inches in 3 sections

$\begin{array}{cr}\text { Weight } & \text { Price } \\ 200 \text { lbs. } & \$ 11.00 \\ 250 \text { lbs. } & 13.50 \\ 300 \text { lbs. } & 16.00 \\ 400 \text { lbs. } & 20.50 \\ 450 \text { lbs. } & 23.00 \\ 500 \text { lbs. } & 25.50\end{array}$

$450 \mathrm{lbs}$.

25.50

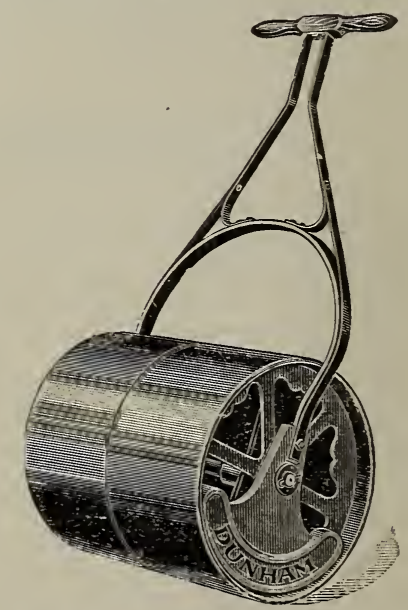

WATER BALLAST ROLLER FOR LAWNS.

With a Water Ballast Roller, one can secure any weight desired, by siply removing a cap and filling with as much water or sand as may be required.

The plug in the drum is coated with a non-rusting compound, so the plug is easily removed with the wrench that is furnished with all rlolers. When filled with sand they weigh $50 \%$ more than with water.

The machine consists of a revolving brush which throws the grass box, which, when full. is ared by merely pulling a leaves, twigs, and by setting it low it is excellent for taking Price, 24 in. $\$ 14.00 ; 28$ in. $\$ 15.00$ Special Golf Green Sweeper 28 in. $\$ 18.00$.

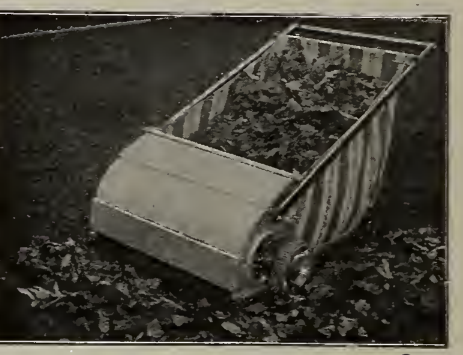

Gem Lawn Cleaner.

No. HW 2. Diam., 14 in.; length, 20 in.; sec., 1; weight empty, 120 lbs.; weight filled, 260 lbs. $\$ 10.00$ No. HW 4. Diam., 18 in.; length, 24 in.; sec., 1; weight empty, 135 lbs.; weight filled, 360 lbs. 12.00 No. HW 6. Diam., 24 in.; length, 24 in.; sec., 1; weight empty, 185 lbs.; weight filled, 560 lbs. 15.50 No. HW12. Diam., 24 in.; length, 32 in.; sec., 2; weight empty, 230 lbs.; weight filled, 710 lbs. 21.50 


\section{LAWN SPRINKLERS.}

CALIFORNIA SPRINKLER.

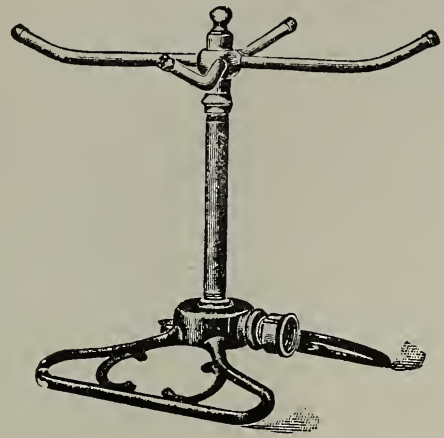

This is the most popular sprinkler on the market. It has four brass arms and is mounted on a sled, so that it can be easily dragged over the lawn without turning off the water. Price, $\$ 1.50$ each.

\section{NEW COIMET.}

Combines the greatest possible capacity in a Lawn Sprinkler with the utmost adjustability and simplicity.

The elbows may be set in any direction and when adjusted will cover a space from 50 to 75 feet in diameter. Each, $\$ 4.00$.

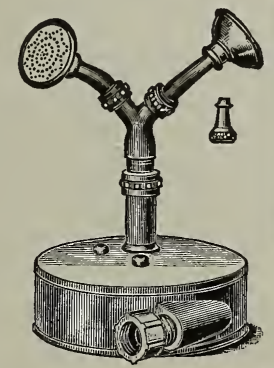

\section{BRASS FOUNTAIN SPRINKLER.}

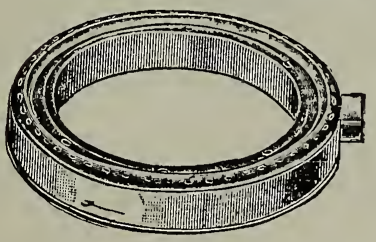

Very simple in construction.

Cannot rust or get out of order.

Will not injure the lawn Requires o n $1 \mathrm{y}$ ordinary pressure of water. Price, $75 \mathrm{cts}$. each.

\section{“'C. B. G." SPRINKLER}

The C. B. Sprinkler is built on the principle of the tangential spray. Simple in construction and canot get out of order. Each, 30 cents.

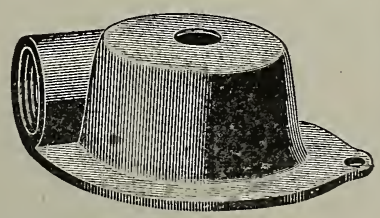

\section{PENNSYLVANIA RAINIMAKER.}

This Sprinkler will cover an area of 300 to 500 square yards with a 40 pound pressure of water and $3 / 4$ in hose.

It works on a turbine principle which turns the wheel carrying it around about eight times to the minute.

For Golf Clubs, Parks and large Estates it is very efficient.

Mounted on sled base. Each \$22.50.

\section{TUXEDO SPRINKLER.}

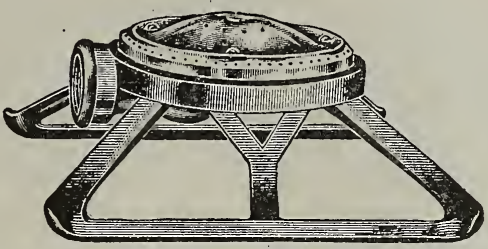

The Tuxedo Sprinkler has a 'brass top, as shown in the cut. firmly screwed down on to an iron sled, the brass of which is $7 \frac{1}{4}$ by $7 \frac{1}{4}$ inches. It throws the water in a copious spray, well distributed. Price, 50 cents each.

\section{HOTCHKISS No. 65.}

An elegant combination sprinkler, has large oval spray cover in addition to the three revolving arms. Very attractive and satisfactory. Price, $\$ 2.00$ each.

\section{LAWN SHOWER. •}

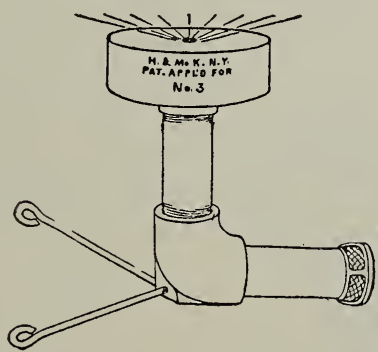

Will throw an even gentle spray over 25 feet in diameter at a water pressure of about 40 pounds, the nozzle may be directly connected to hose for washing sidewalks. Suggested for concrete mixing and general fire protection. It makes an attractive fountain display.

Holder and Nozzle complete. Price, \$2.00.

\section{"WATER WITCH."}

This sprinkler works more satisfactory with a low pressure of water than any other.

With spur to stick in the ground, 75 cents. each; with stand, $\$ 1.25$ each.

\section{IMASHALL'S IMPROVED LAWN SPRINKLER.}

This is a revolwing sprinkler with four or eight arms, standing 48 inches high. It can also be supplied with a wire basket and ball, which is very effective when in use.

4 arm sprinkler ............................... $\$ 40$

8 arm sprinkler ............................. 5.00 $4 \mathrm{arm}$ sprinkler with basket and ball. each, 7.00 8 arm sprinkler with basket and ball. each, 8.00 


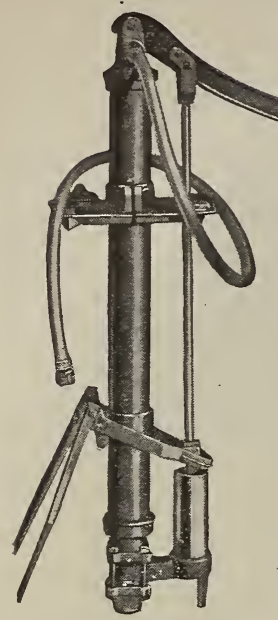

PRIZE BARREL SPRAYER.

This No. 9 needs no further recommendation than it received when at the National Horticultural Contests-it took first prize over six other pumps.

Adjustable plates permit mounting on end or side of either large or small barrels without extra parts or any change whatever.

Submerged brass cylinder $2 \frac{1}{2}$ inches in diameter. Brass valves cage and seat. Special fabric plunger. Air chamber $2 \frac{3}{4}$ inch wrought iron 32 inches long. Double paddle agitator. Brass strainer on intake pipe.

Price, No. 9 . with 5 feet hose and "KANT-KLOG" nozzle .....\$13.50 With two leads of hose, 5 feet each, two galvanized 5 foot pipes and

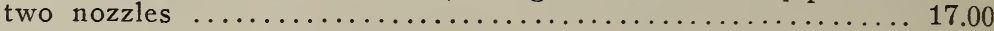

\section{No. 4 ROCHESTER BARREL SPRAYER.}

This Barrel Sprayer can be mounted on either end or side of an ordinary barrel. The churn dash agitator attached to piston thoroughly mixes the solution at every stroke.

Price, No. 4, with $5 \mathrm{ft}$. hose, $5 \mathrm{ft}$. extension pipe and one "KANTKLOG" nozzle ........................... 9.50

\section{"POMONA" BARREL SPRAY PUIMP.}

Very Powerful and Large Capacity-All Working Parts Bronze. The best Orchard Barrel Sprayer. It is unusually powerful and of large capacity, fully capable of supplying four leads of those and eight nozzles. These is nothing about the Sprayer to get out of order, and with ordinary care it will last a lifetime. Pump with Agitator and Hose Coupling.............\$15.00 Outfit C. Pump with Agitator, one lead $15 \mathrm{ft}$., Discharge...

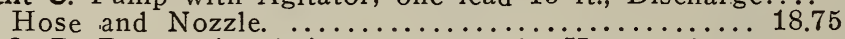

Outfit D. Pump with Agitator, two leads, Hose and two

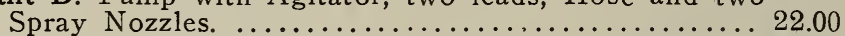

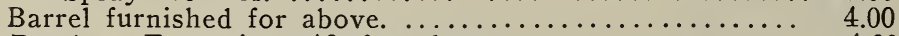

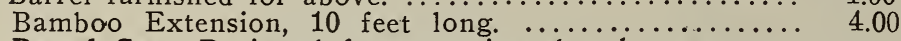

Barrel Cart. Designed for mounting the above sprayers.

Iron wheels with wide tires. With barrel for pump.. 16.00

Without barrel ........................ 12.00

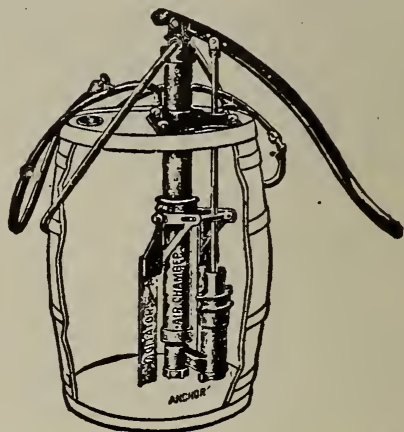

"POMUNA" BARREL SPRAY PUMP

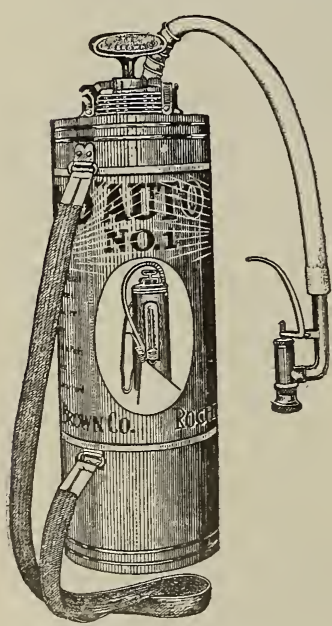

Auto Spray No. 40 C. Compressed air, heavy brass tank, capacity 12 gallons, 8 feet hose, 8 foot extension pipe and "Vermorel" nozzle. Mounted on 20inch wheel truck. A very complete spraying outfit. Frice.

20.00 cattle dip and cattle fly oils. 1 for small work.

Extension Pipe, Brass, $2 \mathrm{ft}$.

\section{AUTO-SPRAY PUMPS.}

No other style of sprayer will do such a variety of work, and do it so 'well. We recommend it for trees, shrubs, and vines, greenhouses, poultry houses, hospitals, and stables for disinfectants, for sheep and

It may be used where any buckets or knapsack sprayer can be used, and with much more satisfaction. Even those who have commercial orchards and large power sprayers need the "Auto Spray" No.

No. 1. A. Brass Tank, with Stop-Cock. .............. \$6.75

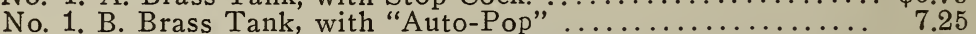

No. 1. C. Galvanized Tank, with Stop-Cock ............ 4.50

No. D. Galvanized Tank, with "Auto-Pop" $\ldots \ldots \ldots \ldots \ldots \ldots \ldots . \quad 5.00$

"Auto-Pop" Nozzle ......1.25

length, each. ...........50

Brass Strainer ........... 1.00

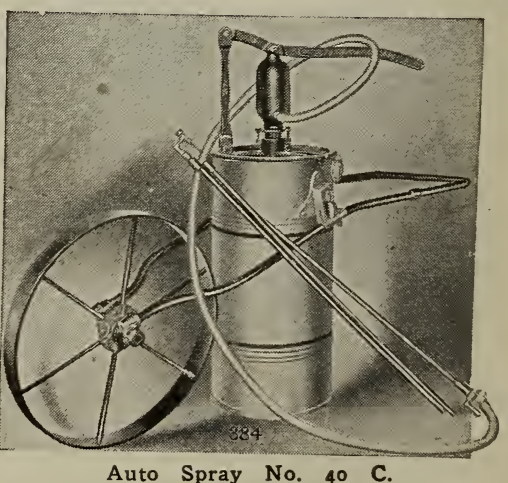




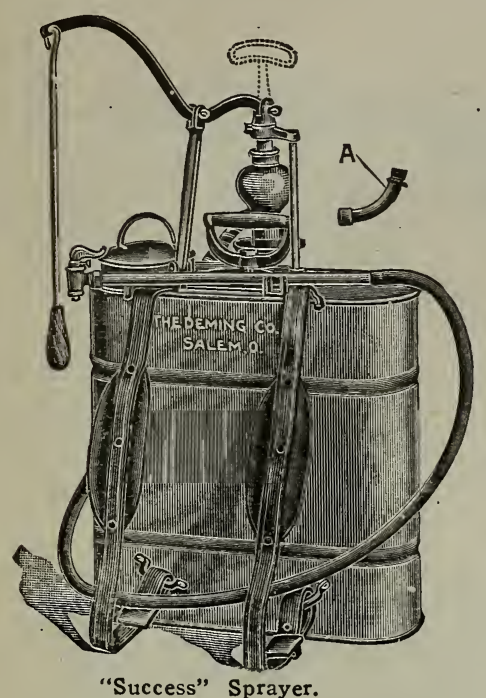

“KANT-KLOG” SPRAYER.

The Sprayer body is made of heavy polished brass or galvanized steel as desired. Both top and bottom are dome shaped; joined to body. under heavy pressure, making a complete double seam.

Each sprayer is fitted with 'KANT-KLOG' nozzle for making two round and one flat spray, two solid streams, thumb pressure Spring Hose-Cock, carrier strap and safety valve.

Galvanized Steel Body.... \$5.50

Polished Brass Body.....7.75

Brass Extension Rods, 3 ft.,

each $\ldots . \ldots \ldots \ldots \ldots . .50$

"SUCESS" SPRAYER.

This Sprayer is undoubtedly the best and most improved on the market. The tank holds 5 gallons and is made of copper thoroughout.

Pump is fitted with bronze valves and mechanical agitator. The attachment $\mathrm{A}$ is used for underspraying. Price ..................\$15.00

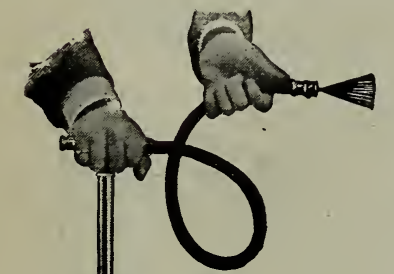

\section{BRASS BUCKET SPRAYERS.}

This Spray Pump is especially designed for spraying in gardens and greenhouses. The pump is double-acting in effect, has gutta percha ball valves. Foot piece is malleable iron. The pump end of discharge hose is 'wire wound.

Price.............\$5.00

\section{JUNIOR No. 5 SPRAY PUMP.}

This pump requires no fastening of any kind. All the operator need do is to press the plunger down. It rises itself by a brass spring. 'Can be used in a pail, tank, or barrel. All parts except handle and hose are solid brass. Complete with hose and nozzles as shown-in cut.

Price............ \$3.50

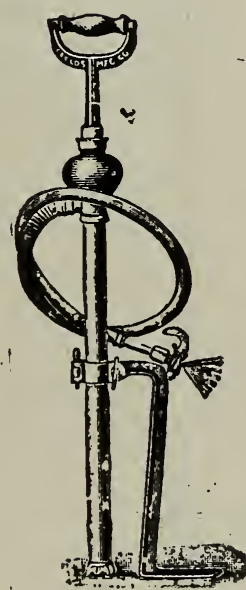

Bucket Pump.

Junior No. 5 Pump.

\section{COMPRESSED AIR SPRAYERS.}

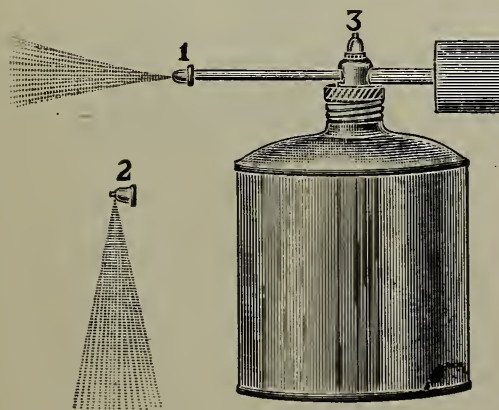

- Straight nos. zle. 2-Universal 1-Shows univer. sal nozzle as at. tached to holder for safe keeping when not in use. To use the universal nozzle it is substituted for the straight nozzle No. I on the end of the tube.

These Patent Sprayers are universally conceded to be the best ever made. They give a continuous spray, reduce the liquid to a fine mist-like vapor and throw it with great force, so that it is driven into the smallest cracks and crevices. By means of the universal nozzle the spray can be thrown on the under side of the leaves of plants and shrubs, and other difficult places inaccessible with the ordinary sprayers.

No. 1. Galvanized Reservoir ........\$1.00 No. 2. Brass Pump and Reservoir........\$2.00 


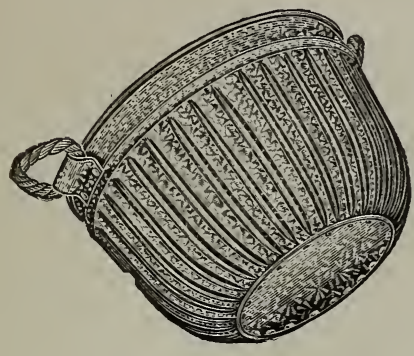

\section{GARDENERS BASKETS.}

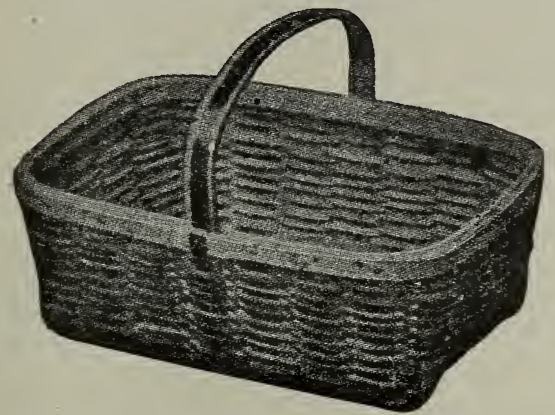

Made with splint and bamboo bound with metal straps. Very strong and durable.

No. 1 size 19 in. $x 11$ in. $x 7$ in. Each $\$ 1.10$

No. 2 size 21 in. $x 12$ in. $x 7$ in. Each 1.25

No. 3 size 25 in. $x 14$ in. $x 8$ in. Each

No. 4 size 27 in. $x 16$ in. $x 9$ in. Each

1.50

1.75

2.00

\section{THE HOPPEN GRINDSTONE.}

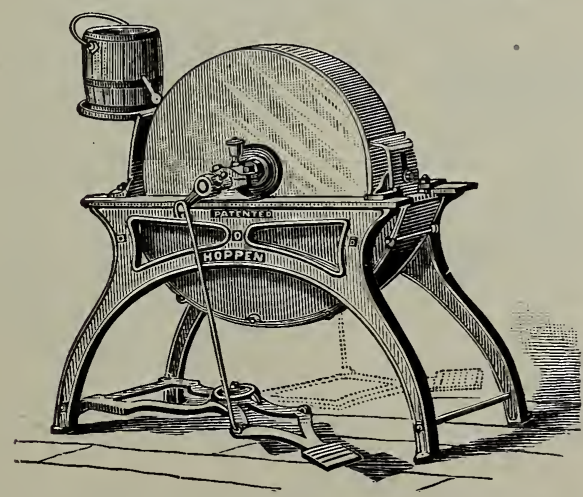

The frame is all iron and is very rigid. Every private estate should have one of these Grindstones on hand.

No. 0. Stone $24 \times 2 \frac{1}{2}$ in., complete ... $\$ 19.00$ No. 1. Stone $24 \times 3$ in., complete .... 20.00 No. 2. Stone $27 \times 3 \frac{1}{2}$ in., complete .... 34.00

\section{GALVANIZED BASKETS.}

This basket will give longer and better use than any other

Useful for vegeta'bles, rubbish and all kinds of garden or Prices:

$\$ 1.50$ each

1.75 each

2.25 each

\begin{tabular}{|c|c|c|}
\hline \multicolumn{3}{|c|}{\begin{tabular}{l}
\multicolumn{1}{c}{ Made especially for } \\
Climbing Roses and \\
Vines. Heavy iron, \\
painted dark green; \\
very ornamental.
\end{tabular}} \\
\hline 27 & $2 \mathrm{ft} . \quad 7 \mathrm{ft}$. & $\$ 6.50$ \\
\hline 28 & $2 \mathrm{ft} . \quad 8 \mathrm{ft}$. & \\
\hline 29 & $2 \mathrm{ft} . \quad 9 \mathrm{ft}$. & 7.5 \\
\hline 210 & $2 \mathrm{ft} .10 \mathrm{ft}$. & 8.00 \\
\hline 37 & $3 \mathrm{ft} . \quad 7 \mathrm{ft}$. & 7.0 \\
\hline 38 & $3 \mathrm{ft} . \quad 8 \mathrm{ft}$. & 7.50 \\
\hline 39 & $3 \mathrm{ft} . \quad 9 \mathrm{ft}$. & \\
\hline 310 & $3 \mathrm{ft} .10 \mathrm{ft}$. & 8.5 \\
\hline 48 & $4 \mathrm{ft} . \quad 8 \mathrm{ft}$. & 8.00 \\
\hline 49 & $4 \mathrm{ft} . \quad 9 \mathrm{ft}$. & 8.50 \\
\hline 410 & $4 \mathrm{ft} .10 \mathrm{ft}$. & \\
\hline
\end{tabular}

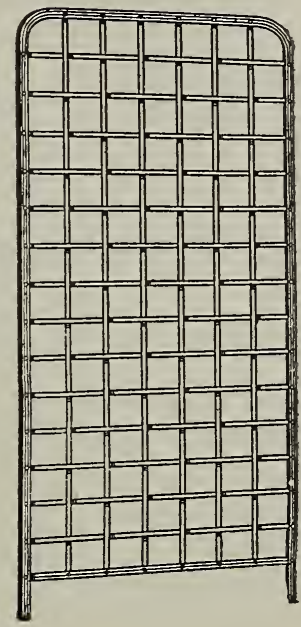

\section{GARDEN ARCH.}

Made with heavy iron, painted dark green. Size: $8 \mathrm{ft}$. high, $5 \mathrm{ft}$. wide, $3 \frac{1 / 2}{\mathrm{ft}}$. deep. Price $\$ 15.00$.

\section{GRASS SOD TAMPERS.}

Useful for tamping down grass sod and uneven spots on Lawns. Tennis Courts and Golf Grounds. Made of iron. with heavy wooden handle.

\begin{tabular}{|c|c|c|}
\hline \multicolumn{3}{|c|}{ Square Pattern } \\
\hline$z$ & Weight & Each \\
\hline & 12 lbs. & $\$ 1.0$ \\
\hline & 17 lbs. & 1.2 \\
\hline
\end{tabular}

\section{Round Pattern.}

Size Weight

5 in. 15 lbs.

6 in. 20 lbs.

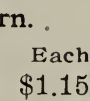

1.35

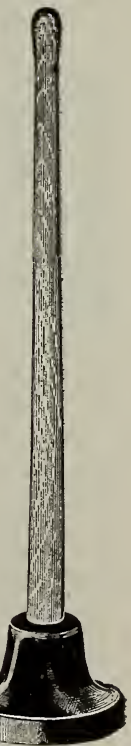




\section{F A R M O G E R M. \\ HIGH-BRED NITROGEN FIXING BACTERIA.}

All the Nitrates You Need for $\$ 2.00$ Per Acre. Reduce Your Fertilizer Bill $75 \%$.

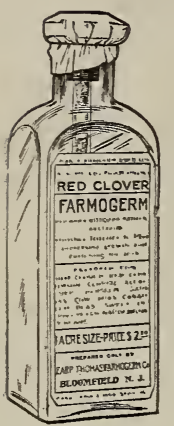

The use of Farmogerm on the seeds of Peas. Beans, Clovers, Alfalfa, and all other legumes mears an earlier and bigger crop and a large amount of Nitrates added to the soil to benefit future crops of other kinds. Ready to use simply by moistening the seeds before planting.

Raise the biggest and best crop of peas, beans, sweet peas, clovers, alfalfa or vetches you ever had.

Improve your land by the use of Farmogerm High-Bred Bacteria which add nitrogen to the soil for future crops.

Prepared for; Alfalfa, Canadian Filed Peas, Garden Beans, Cow Peas..

Clover, Soy Beans, Garden Peas, Vetch.

In garden sizes, $25 \mathrm{c}$. and $50 \mathrm{c}$. each. Acre sizes, $\$ 2.00$ per acre size $\$ 6.50$.

In ordering state what legume you wish to plant.

It is impossible to explain this subject fully on a single page of our catalogue Write for special circular.

\section{FERGUSON'S NITROGEN BACTERIA THE MODERN WAY TO}

\section{INCREASE CROPS AND RESTORE SOIL FERTILITY.}

The United States Department of Agriculture the Federal Reserve Board, the State Departments and Colleges all advise "Diversify crops, grow legumes, get nitrogen into the soil." The way to do this is to treat the seed with Ferguson's Nitrogen Bacteria at the time of planting. Costs little, does a great deal.

Ferguson's Nitrogen Bacteria is of value on every kind of legume-including all clovers, alfalfa, peas, beans, vetch, etc. The bacteria draws nitrogen from the air and deposits it on the plant roots in the form of nitrates, available for use. It makes the plant grow larger and yield more and it improves the soil. Ferguson's bacteria is in liquid form and the same bottle can be applied to any form of legume.

Garden or quarter acre size.......... $\$ 0.50$

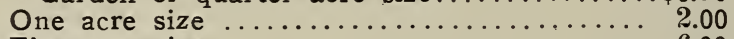

Five acre size .............................. 6.00

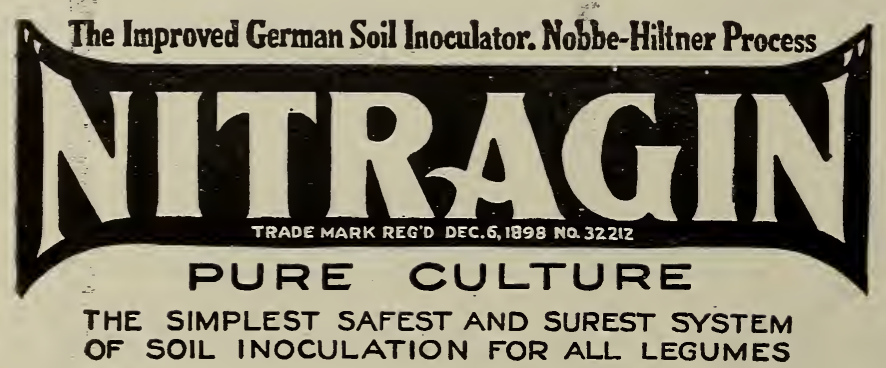

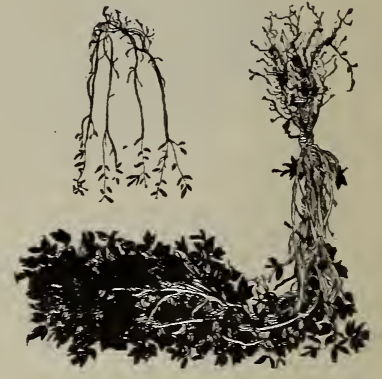

ALFALFA PLANTS

Those on the left were in. oculated with Ferguson's Nitro. gen-Fixing Bacteria. Those on the right were not inoculated. Notice nodules on the inoculat. ed plant.

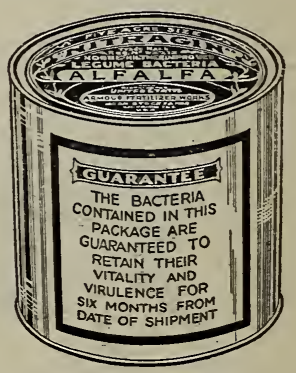

Remember each legume requires its own particular kind of bacteria. A special strain of "NITRAGIN" Pure Culture is prepared for each legume. In ordering be sure to name crop desired.

Soil inoculation by "NITRAGIN" Pure Culture simoly means seed safety and crop insurance. It it not expense, but an investment which will yield twenty-fold returns. No mystery about it. Simply millions of strong healthy germs, guaranteed for six months. You legumes must have these germs to draw nitrogen from the air. Easy to apply - a boy can do it. Just add water and mix with seed-let dry-plant as usual.

Prices, per can: Garden size, $\$ 1.00$; acre size, $\$ 2.00 ; 5$-acre size, $\$ 9.00$

Express extra. Parcel post, 10 cents extra per acre extra. 


\section{F E R T I L I Z E R S}

BASIC SLAG.

A soil sweetening Phosphate containing half its weight of Lime. Useful for sour soils and Grass plots. 5 lbs., 25 cts.; 100 lbs., $\$ 2.25$.

BONE MEAL. Bowker's Pure Bone Dust.

This bone meal is made from the best quality of bone and finely pulverized. 5 1bs., 30 c., 10 lbs., 50c.; 50 lbs., $\$ 1.75$; 100 lbs., $\$ 3.00 ; 200$ lbs., $\$ 5.50$; ton. $\$ 45.00$.

\section{BONE, CRUSHED.}

A coarse grade, well adapted for grape vine, rose borders. 100 lbs., $\$ 4.00$; ton, $\$ 60.00$.

\section{BLOOD AND BONE.}

It is of value for garden crops, fruit trees, grape vines, etc. For garden crops, drill in 300 to 500 lbs. per acre. 100 lbs., $\$ 2.50 ; 200$ lbs., $\$ 4.50$; ton, $\$ 45.00$.

\section{BONARBOR.}

This plant food has a 'wonderful effect on plant life. It is good for flowering plants of all kinds, vegetable, fruits and shade trees, lawn, etc. $1 / 2$ lb. pkg., 25 c.; 1 lb. pkg., 40c.; 5 lbs., pkg., $\$ 1.75$.

\section{CLAY'S FERTILIZER.}

This is one of the best manures for all horticultural purposes, either in greenhouse or garden. It is proluctive and lasting. $28 \mathrm{lbs}$., $\$ 2.25 ; 56$ lb. bag, $\$ 4.00 ; 112$ lb. bag, $\$ 7.00$.

\section{COW MANURE}

Per ton $\$ 2.50$ f. o. b. Bushwick, L. I.

\section{DRIED BLOOD.}

For top dressing, mixing with the soil and applying in liquid form, it is one of the best and sâfest nitrogenous fertilizers. 100 lbs., $\$ 5.00$.

HIGH GRADE CHEMICAL FERTILIZER.

A crop producing, well balanced fertilizer for general garden use. $1 \mathrm{lb}$. tin, $25 \mathrm{cts}$; $5 \mathrm{lb}$. tin, 70 cts.; 50 lb. bag, $\$ 3.50 ; 100$ lb. bag, $\$ 5.00$.

\section{HORSE MANURE.}

Well rotted, dried and ground. Per 100 lbs. $\$ 2.00$. Per ton. $\$ 33.00$ f. o . b. Monmouth Junction, N. J.

\section{H U M U S.}

Valuable for all garden purposes, including Lawns and Greenhouse Plants. 4 lb. can, 40 cts. bag, $\$ 1.50$; ton, $\$ 15.00$.

\section{LAND PLASTER OR GYPSUM.}

An excellent addition to land for such crops as require lime and sulphates, particulary turnips, potatoes, grasses, etc. 100 lbs., $\$ 1.50$; ton, $\$ 15.00$.

\section{LIME, AGRICULTURAL.}

Useful for sour land and alfalfa. $100 \mathrm{lbs}$., $\$ 1.00$; ton, $\$ 15.00$.

LIMESTONE, GROUND.

Per ton, $\$ 5.00$ f. o. b. factory, bags extra.

\section{MURIATE OF POTASH.}

A high grade fertilizer, and one of the best for use, and general stimulator. Market Prices.

\section{NITRATE OF SODA.}

It is valuable for grain, corn, beets, potatoes, grasses, peas, beans, clover, etc. Being extremely soluble, it should not be applied until the plants are above ground. 1 lb., 15 cts., 5 lbs., 50 c., 10 lbs., 90 c., 50 lbs., $\$ 3.50 ; 100$ lbs., $\$ 5.00$.

\section{PERUVIAN GUANO.}

A high grade fertilizer for all garden crops and garden purposes. $1 \cdot 1 \mathrm{~b} ., 30$ cts.; 5 lbs., $\$ 1.00$; 50 lbs., $\$ 4.50 ; 100$ lbs., $\$ 7.50$.

\section{PHOSPHATE.}

Solua'ble. $14 \%$. Market prices.

\section{PULVERIZED SHEEP MANURE.}

A rich, pure and natural manure. Excellent as a top dressing for lawns, and mixing with the soil for greenhouse plants-one part manure and six part soil. $5 \mathrm{lb}$. package, $25 \mathrm{c}$; $10 \mathrm{lbs}$. 50 c.; 50 lbs., $\$ 1.25$; 10 ibs., $\$ 2.00$; ton, $\$ 35.00$.

\section{SALT, AGRICULTURAL.}

Used for top dressing asparagus beds, etc. Should be used in the Spring. 100 lbs., $\$ 1.50$; 200 lbs., $\$ 3.00$.

\section{STABLE MANURE.}

Well rotted, ready for use. Carloads. Per ton \$2.10. f. o. b. Bushwick, L. I.

\section{SOOT, IMPORTED SCOTCH.}

A fertilizer for stimulating growth and giving a rich, dark foliage; also an excellent remedy aginst slugs, grubs and cutworms when mixed in the surface of the soil. Bag of $100 \mathrm{lbs} ., \$ 4.50$.

\section{THOMPSON'S CHRYSANTHEMUM MANURE.}

A special top dressing of unusual merit. 28 lbs., $\$ 4.50$; 56 lbs., $\$ 7.50 ; 112$ lbs., $\$ 15.00$.

\section{THOMPSON'S VINE AND PLANT MANURE.}

A well known English fertilizer. 56 . 1bs $\$ 4.00 ; 112$ lbs., $\$ 7.00$.

\section{WOOD ASHES, UNLEACHED.}

For lawns, gardens and fruits, Hardwood ashes are unequaled. 100 lbs., $\$ 1.50$; ton, $\$ 22.00$.

\section{SPECIAL TRUCK FERTILIZER.}

For all kinds of Vegetables. Analysis 4-87\%. Market prices.

\section{GENERAL TRUCK FERTILIZER.}

For Potatoes and Vegetables. Analysis 2-7 -7\%. Market Prices.

CORN AND CEREAL FERTILIZER.

Analysis 2-6-3\%. Market Prices.

Owing to conditions in Europe, prices of Fertilizers are subject to market prices. 


\section{N S E C T I C I D ES}

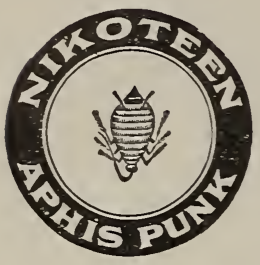

convenient way of applying an insecticide ever yet devised.

Per case 1 Doz. Airtight Containers,

I Doz. Sheets each, $\$ 6.50$ I Doz. Sheets in Airtight Package, 60 cents.

APHINE. This liquid insecticide will kill plant lice of every species. Gill, 25 c.; $1 / 2$ pint, $40 c$.; pint, 65 c.; quart, $\$ 1.00$; gallon, $\$ 2.50$.

ANT DESTROYER. A non-poisonous powder Will destroy or drive away black ants. Box, 10c.; 1/4 lb., 2 5̃c.; $1 / 2$ lb., 40c., lb., 7 óc.

ARSENATE OF LEAD. For spraying all kinds of trees. Kills the Rose bugs and Elm beetle. Dilute $1 \mathrm{lb}$. to 20 gals. water. Per lb.,

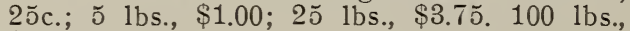
$\$ 12.00$.

ARSITE. A liquid poison for potato bugs. Most concentrated poison made, $1 / 2$ pint makes 50 gallons. So adhesive that rains will not wash it off, thereby saving time and material. Must be used with Bordeaux Mixture or water to which some freshly slaked lime has been first added. Very economical. $1 / 2$ pint, 35̃c.; pint, 65 .

BORDO-LEAD. A mixture of Bordeaux and Arsenate of Lead. Two sprays in one, Insecti cide and Fungicide. 1 lb., 25 cts.; 5 lbs., $\$ 1.00$; 25 lbs., $\$ 1.50$.

BORDEAUX MIXTURE. A reliable remedy for the prevention of fungus and fungoid diseases.

Liquid, qt., 35̃c.; gal., $\$ 1.00 ; 5$ gals. $\$ 4.500$.

Dry form, 1 lb. box, 20c.; 5 lbs., 90c.

BOROWAX. A complete protection against borers, if properly applied to peach, plum, apple, pear and quince trees. Qt. 35 cts. gal. $\$ 1.00,6$ gals. $\$ 5.00$.

BUG DEATH. Is extensively used for cabbage and tomato worms, potato and cucumber bugs. 1 lb., 15c.; 3 lb., 35̆c.; 5 lbs., 50c.; $12 \frac{1 / 2}{2}$ lbs., \$1.00; 100 lbs., $\$ 7.7$ गे

CALITE. A positive destroyer of all leaf-eating insects attacking fruit, shade trees, etc. Ready-mixed for use with plain water, Lime Sulphur Solution etc. So adhesive that rains will not wash it off. Most efficient and convenient insecticide for all garden and truck work. 1 pint makes 50 gallons. Pint, $30 \mathrm{cts}$.

CATTLE COMFORT. Protects cattle, dogs, etc., from flies and other insects. Qt., $450 \mathrm{c}$; gal., \$1.2 ̃.

COPPER SOLUTION. For Mildew, Pear and Apple Scab, rust on Carnations and Violets. Gal., \$1.50.

CUT. WORM KILLER. This is a coarse powder for sprinkling near the plants to be protected. It is harmless to birds or chickens. One pound is sufficient for 175 plants or 100 feet of drill. 1 lb., 25̌c.; 5 lbs., $\$ 1.00 ; 25$ lbs.,

FIR TREE OIL SOAP. Useful on greenhouse and garden plants, killing red spiders, mealy bugs, aphis, etc., $1 / 2$ lb. tin, $25 \mathrm{c}$.; 2 lbs., $75 \mathrm{c}$.

Y KNOCKER. Protects all animals from flies. Quart, 35̆c.; 1/2 gal., 60c.; gal., $\$ 1.00$.

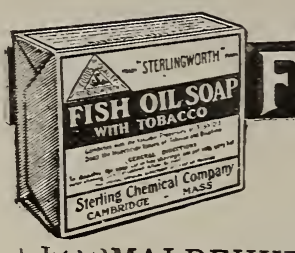

FURMALDEHYDE. Potato Scab, Rosette in Lettuce, Onion Smut and fungus in soil. For Potatoes use 1 pound to 30 gallons of water and soak the tubers about $1 \frac{1}{2}$ hours before planting. Per lb., 3こ̃c.

FUNGINE. An infallible remedy for mildew and other fungus diseases. Pint, $50 \mathrm{c}$.; quart, 7 ว̌c.; gallon, $\$ 2.00$.

GISHURST COMPOUND. An English preparation for greenfly, scale, mealy bug, red spider, etc. $1 \mathrm{lb}$. box, 50 cts.

GRAPE DUST. For the prevention of mildew on roses, grapes, gooseberries, etc. $5 \mathrm{lb}$. pkg., 3 ว̆c.; 100 lb. keg, $\$ 6.00$.

HELLEBORE POWDER. For rose slugs currant worms, etc. Dust on with gun or bellows while the foliage is moist. $1 / 4 \mathrm{lb}$., 10c.; 1/2 1b., 20c.; 1 1b., 35c.; 5 1b., \$1.60.

IMP SPRAY SOAP. Mix with 12 parts of water for spraying. Gal., \$1.65.

KEROSENE EMULSION. The best insecticide for general use on all plants, indoors, or out. Qt., 30c.; gal., \$1.00; 5 gal., \$3.50.

LEMON OIL. For destroying mealy bugs, scale thrip, red spider, etc. $1 / 2$ pt.,, 2 oc.; 1 pt., 40c.; qt., 75.; 1/2 gal., $\$ 1.25$; 1 gal., $\$ 2.00$.

LIME SULPHUR SOLUTION. For spraying fruit trees. Gal., 75 c.; 5 gal., $\$ 2.50$.

NICO FUME LIQUID. For spraying or fumigating. Does not stain or injure the blooms, 1 lb., $\$ 1.50$; 4 lbs., $\$ 5.50 ; 8$ lbs., $\$ 10.50$.

NICO FUME PAPER. Extra strong tobacco paper for burning. 24 sheets, 85 cts.; 144 sheets, $\$ 4.00 ; 288$ sheets, $\$ 7.50$.

NICOTICIDE. Fumigating compound. A certain destroyer of all greenhouse bugs. One pint sufficient for 32,000 cubic feet. Pint, $\$ 2.00$; qt., $\$ 4.00 ; 1$ gal., $\$ 1$ õ.00.

Fumigators for above. $60 \mathrm{c}$. each.

NIKOTEEN. 30\% strength. A thorough exterminator of mealy bug, thrip. lice and all insects affecting plant life. $1 \frac{3 / 4}{0}$ oz., $40 \mathrm{c}$.; 1 lb., $\$ 1.50 ; 8$ lb. tins, $\$ 10.00$.

NIKOTIANA. A $12 \%$ Nicotine solution proper ly diluted. For spraying and fumigating. Qt., $\$ 1.50$; gal., $\$ 4.50$.

PARIS GREEN. For potato bugs, etc 1/4 lb., 10c.,; 1/2 1b., 20c.; 1 lb., 40 c.

SCALINE. A scalicide, insecticide and fungicide combined. Qt.. 7 óc.; gal., $\$ 1.50 ; 5$ gals., $\$ 6.25$; 10 gals., $\$ 10.00$; bbl. (50 gals.), $\$ 37.50$. 


\section{INSECTICIDES--Continued.}

SCALECIDE. For San Jose scale and spraying all kinds of trees. 1 gal. can, $\$ 1.00$; 5 gals., $\$ 3.50 ; 10$ gals., $\$ 6.50 ; 50$ gals., $\$ 25.00$.

SLUG SHOT. Destroys all insects injurious to house and garden plants, vegetables and fruits of all kinds. $1 \mathrm{lb}$. cartons, $15 \mathrm{c}$; $51 \mathrm{~b}$. pkg., 35c.; 10 lbs., 60 c.; keg of 125 lbs., $\$ 7.50$.

SLUG SHOT DUSTER. Each, 35 cts.

SULPHUR, Powdered. A staple preventive for mildew on grapes, roses, etc. Lb., 10c.; 10 lbs., 65c.; 25 lbs., and over, 6c. per lb.

SULTAR INSECTICIDE. A valuable disinfect ant and insecticide. Useful for spraying chicken houses. dog kennels, etc. Per gal., $\$ 3.00$.

TREE TANGLEFOOT. A sticky substance applied directly to the bark. To protect trees against climbing insect pests. One application remains stickly, fully exposed to weather, three months. One pound will make a band 7 to 8 feet long. 1 lb. can, 30 cts.; 3 lbs., $85 \mathrm{c}$.; 10 lbs., $\$ 2.65 ; 20$ lbs., $\$ 4.80$.

\section{WEED KILLERS.}
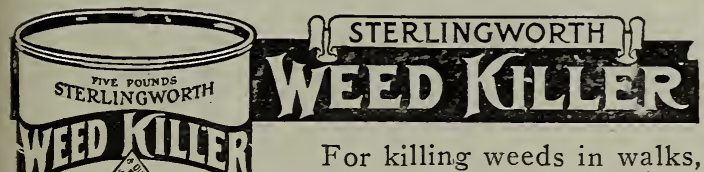
drives and tennis courts where no vegetation is wanted. In powder form, to be dissolved in water. 1 lb. makes 15 gallons, sufficient for 50 square yards. 1 lb: pkg., 50c.; 5 lb. pkg., $\$ 2.00$.

HERBICIDE. A liquid preparation for the killing of weeds of every kind on roadways, paths, gutters, tennis-courts. May be applied by means of sprinkling can or the large street sprinkling wagon. $1 / 2$ gal. makes 10 gals. liquid, 80 cts.; 1 gal., $\$ 1.50$; 5 gals., $\$ 5.50 ; 10$ gals. $\$ 10.00 ; 25$ gals., $\$ 21.50$.

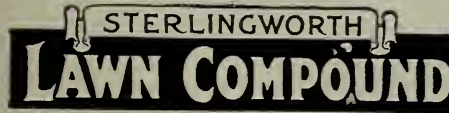

Kills weeds in Lawns without killing the Grass, and makes the Lawn green and velvety.

It is a non-poisonous dry powder which adhers to the broad flat leaves of weeds and

does not stick to the grass because of its upright growth and smooth surface. The ingredients in combination with the sun's rays burn out the weeds. It is easily applied by sprinkling over the weedy lawn. One pound will dress 100 to 200 square feet, depending upon the lawns condition.

$5 \mathrm{lb}$. cans, 60 cts.; $50 \mathrm{lb}$. kegs, $\$ 4.00 ; 100 \mathrm{lb}$. kegs, $\$ 7.50$.
TOBACCO DUST. Destroys rose lice, cabbage and turnip fleas, etc. Lb., 10c.; 5 lbs., 35c.; 10 lbs., 60c.; 100 lbs., $\$ 3.50$.

TOBACCO DUST FUMIGATING. Used for burning in place of stems. 10 lbs., 60c.; 50 lbs., $\$ 2.00 ; 100$ lbs., $\$ 3.50$.

TOBACCO STEMS FOR FÜMIGATING. Clean and free from rubbish. In bales of 100 lbs., $\$ 1.75$ each; 300 lbs., $\$ 4.50$.

VERMINE. For all soil vermine, such as cut. eel, or wire worms, slugs, root lice and ants $1 / 2$ pt., 40 c.; 1 pt., 6 ธ̌c.; qt., $\$ 1.00 ; 1$ gal., $\$ 3.00$

WHALE-OIL SOAP. See Fish Oil Soap.

WILSON'S PLANT OIL. For killing scales on palms and other plants. Gal., $\$ 2.00$.

WORM ERADICATOR. "Radix" for destroying worms in flower pots, lawns, tennis courts, etc. Dry form, $1 \mathrm{lb}$. box $50 \mathrm{cts}$. Liquid form, 1 gal., $\$ 2.00$; 10 gals., $\$ 1.75$ per gal.

WORM ERADICATOR. Rhead's Electric. For destroying worms in lawns, pots. etc. One gallon makes 150 gallons solution. Gal., $\$ 4.00$

X. L. ALL LIQUID INSECTICIDE. For spraying. Harmless to very delicate plants; kills all insect pests. Qt., $\$ 1.00 ; 1$ gal., $\$ 3.50$.

\section{Sticky Tree Cord. \\ Trees banded, with} Stickly Tree Cord are not unsightly. It is far the easiest, most effective and most economical method. No injury is sustained by the tree because little material comes out of the cord and it is non-poisonous. Rough barked trees such as Poplar, Gum, etc. should have a channel two inches wide cut into the bark to give a fairly smooth surface for the cord. No caterpillar, slug, worm or other insect can cross it nor go underneath it if properly applied. It is easy to remove in the fall. leaving very little trace.

Per tube containing about 30 feet of cord. $25 \mathrm{cts}$.

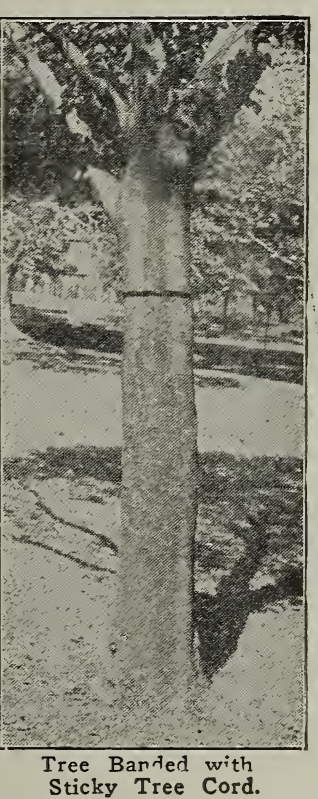

\section{TREE WOOD PAINT.}

Tree Wound Paint when applied is an insurance against decay after pruning trees.

It is an ideal material required in all tree surgery operations, antiseptic and penetrating, forming a lasting, water-proof coating which does not injure the growth or healing of the wound. Price, gal. can, $\$ 1.50 ; 5$ gal. can, $\$ 6.50$. 
THE “VELVETLAWN' SEEDER.

An excellent New Machine'for Seeding Old or New Lawns.

Puts Seeds in old sod or new ground securely. Covers and rolls same.

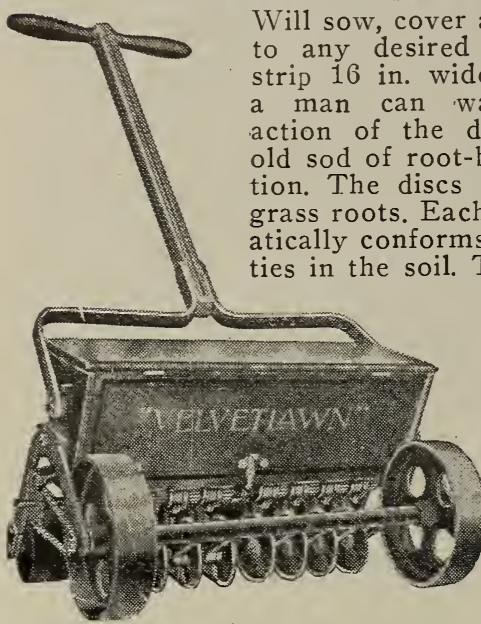

Will sow, cover and roll seed to any desired depth in a strip 16 in. wide, as fast as a man can walk. Cutting discs relieves root-bound condition. The discs cultivate the grass roots. Each disc automatically conforms to in equali. ties in the soil. The operator c a n d rill any amount of $\mathrm{s}$ e e d lesired. The "Velvet awn" Grass Seeder puts the seed in the ground, not on top. Birds, wind and rain will have no ill effect when the seed is drilled into the soil.

The discs do not tear the soil, they cut it. All the seed being planted at an even depth in the soil, the plants must all come up at the same time, and make uniform krowth.

Price, F. O. B. New York, $\$ 18.00$.

\section{SIMPLEX WATERPROOF PLANT}

\section{LABELS.}
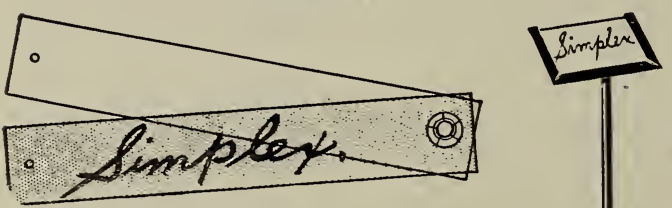

The writing is protected by the transparent cover.

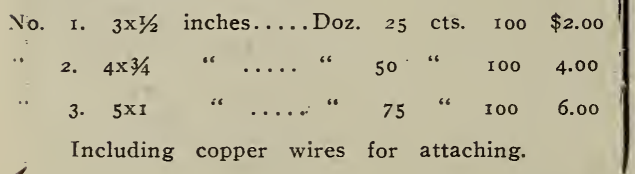

\section{SIMPLEX GARDEN LABEL.}

This label is used for marking plants in borders etc. The rod is 18 inches long and the card for writing on is $1 \frac{1 / 2}{2}$ by $2 \frac{3}{4}$ inches which is made from celluloid with a transparent cover. Per doz., $\$ 2.00$; per $100, \$ 15.00$.
THE ROHO RAKE.

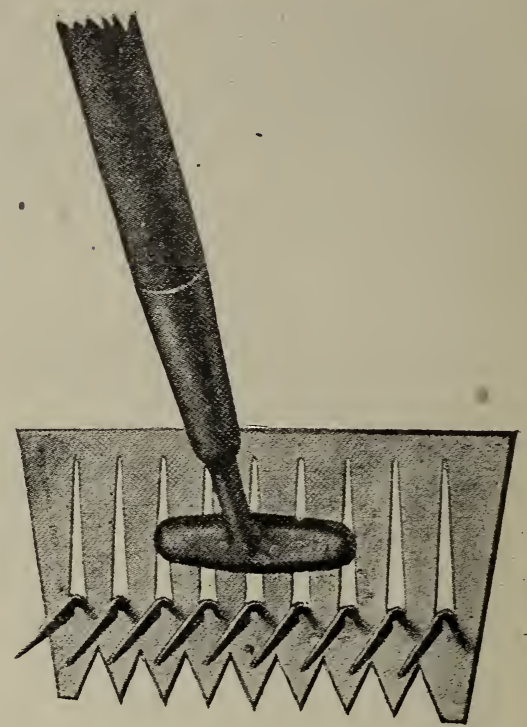

A valuable garden tool for cleaning weeds from Walks, Drives, Tennis Courts etc. It can be used as a draw hoe, or scuffle hoe and also. as a rake. Light and easy to handle, made with unbreakable steel. Each $\$ 1.00$.

\section{THE ALL-PROOF LABEL.}

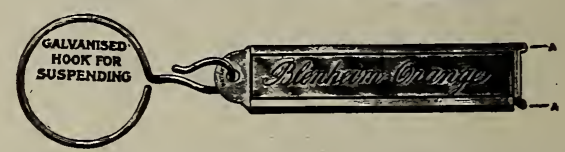

Made with zinc, having a white enameled surface for the name which is covered with a glass slide.

No. 1. for hanging $3 \frac{1}{2}$ in. long ... $\$ 0.60 \$ 6.00$

No. 2. For pots or borders, 6 in. long .60 .6 .00

No. 3 . For pots or torders, 8 in. long. $70 \cdot 7.00$

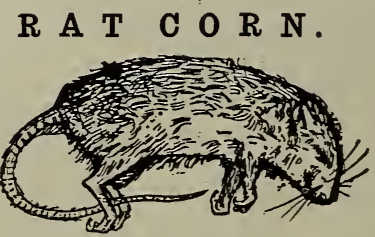

A safe and sure exterminator of Rats and Mice. This is not a poison and can be used without fear when other animals are around. No smell from the dead rats is detected, as the bodies dry up after death.

Full directions with each package.

Sizes, 25 cts., $50 \mathrm{cts}$. and $\$ 1.00$. 


\section{PLANTING TABLE FOR VICINITY OF NEW YORK}

\begin{tabular}{|c|c|c|c|c|}
\hline MARCH & APRIL & MAY & JUNE & JULY \\
\hline IN HOTBED & IN HOTBED & IN GARDEN & IN GARDEN & IN GARDEN \\
\hline $\begin{array}{l}\text { Beans } \\
\text { Beets } \\
\text { Early Cabbage } \\
\text { Carrot } \\
\text { Cauliflower } \\
\text { Celery } \\
\text { Egg-Plant } \\
\text { Kohlrabi } \\
\text { Lettuce } \\
\text { Parsley } \\
\text { Pepper } \\
\text { Radish } \\
\text { Tomato } \\
\text { IN GARDEN } \\
\text { Beets } \\
\text { Carrot } \\
\text { Leek } \\
\text { Onion } \\
\text { Peas } \\
\text { Potatoes } \\
\text { Radish } \\
\text { Spinach } \\
\text { Turnip } \\
\end{array}$ & $\begin{array}{l}\text { Cucumber } \\
\text { Egg-Plant } \\
\text { Melon } \\
\text { Pepper } \\
\text { Tomato } \\
\text { IN GARDEN } \\
\text { Asparagus } \\
\text { Beets } \\
\text { Eary Cabbage } \\
\text { Carrot } \\
\text { Cauliflower } \\
\text { Celery } \\
\text { Kohlrabi } \\
\text { Lettuce } \\
\text { Onion } \\
\text { Parsley } \\
\text { Parsnip } \\
\text { Peas } \\
\text { Potatoes } \\
\text { Radish } \\
\text { Spinach } \\
\text { Turnip } \\
\end{array}$ & $\begin{array}{l}\text { Artichoke } \\
\text { Asparagus } \\
\text { Beans, Bush } \\
\text { Beans, Running } \\
\text { Beets } \\
\text { Carrot } \\
\text { Cauliflower } \\
\text { Celery } \\
\text { Sweet Corn } \\
\text { Cucumber } \\
\text { Kohlrabi } \\
\text { Leek } \\
\text { Lettuce } \\
\text { Melon } \\
\text { Onion } \\
\text { Parsley } \\
\text { Peas } \\
\text { Radish } \\
\text { Salsify } \\
\text { Spinach } \\
\text { Turnip } \\
\text { Herbs }\end{array}$ & $\begin{array}{l}\text { Beans, all sorts } \\
\text { Beets } \\
\text { Broccoli } \\
\text { Brussels Sprouts } \\
\text { Late Cabbage } \\
\text { Carrot } \\
\text { Cauliflower } \\
\text { Sweet Corn } \\
\text { Cucumber } \\
\text { Endive } \\
\text { Kale } \\
\text { Kohlrabi } \\
\text { Lettuce } \\
\text { Melon } \\
\text { Nasturtium } \\
\text { Okra } \\
\text { Peas } \\
\text { Potatoes } \\
\text { Punpkin } \\
\text { Radish } \\
\text { Salsify } \\
\text { Spinach } \\
\text { Squash } \\
\text { Herbs } \\
\end{array}$ & $\begin{array}{l}\text { Beans } \\
\text { Beets } \\
\text { Carrot } \\
\text { Sweet Corn } \\
\text { Corn Salad } \\
\text { Cress } \\
\text { Cucumber } \\
\text { Endive } \\
\text { Kale } \\
\text { Kohlrabi } \\
\text { Lettuce } \\
\text { Okra } \\
\text { Early Peas } \\
\text { Pumpkin } \\
\text { Radish } \\
\text { Spinach } \\
\text { Squash } \\
\text { Turnip } \\
\text { Ruta-Baga }\end{array}$ \\
\hline \multicolumn{3}{|c|}{ AUGUST IN GARDEN } & \multicolumn{2}{|c|}{ SEPTEMBER } \\
\hline $\begin{array}{l}\text { Beans, Bush } \\
\text { Corn Salad } \\
\text { Endive }\end{array}$ & $\begin{array}{l}\text { Welsh Onion } \\
\text { Lettuce } \\
\text { Early Peas }\end{array}$ & $\begin{array}{l}\text { Radish } \\
\text { Spinach } \\
\text { Turnip }\end{array}$ & $\begin{array}{l}\text { Corn } \\
\text { Salad } \\
\text { Lettuce }\end{array}$ & $\begin{array}{l}\text { Radish } \\
\text { Spinach } \\
\text { Turnip }\end{array}$ \\
\hline
\end{tabular}

\section{N D X}

Page

Achimenes ........... 12

Agapanthus $\ldots \ldots \ldots \ldots \ldots$. 63

Amaryllis .............. 63

Aquatic Plants .......... 60

Arches .............. 91

Bamboo Canes............. 70

Baskets ............ 91

Bean Poles .............. 77

Bedding Plants ......... 61

Begonias ...........6. $61-63$

Bird Houses ........ 77

Bird Seeds ............. 30

Bone Mills .......... 79

Books $\ldots \ldots \ldots \ldots \ldots \ldots, 12$

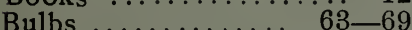

Cannas $\ldots \ldots \ldots \ldots \ldots \ldots \ldots .6 .64$

Caladiums $\ldots \ldots \ldots \ldots \ldots, 63$

Callas .................. 63

Carnations $\ldots \ldots \ldots$ 10, 61

Cinnamon Vine ........ 64

Chrysanthemums .... 10, 58

Clovers ............. 36

Cold Storage Bulbs ...... 11

Corn, Field ........... 32

Corn Planter .......... 79

Cultivators $\ldots . . . \cdots \cdots$

Dahlias .... 9,64 64-65-66

Daylight Cleaner ..... 80

Farmogerm ............. 92

Farm Seeds …....... 32

Ferns $\ldots \ldots \ldots \ldots \ldots \ldots \ldots .62$

Fern Balls $\ldots \ldots \ldots \ldots \ldots, 60$

Fertilizers $\ldots \ldots \ldots \ldots \ldots \ldots$. 93

Fertilizers Sower ........ 78
Flower Guards ...... Page 79

Flower Pots ............ 70

Flowers Seeds .... 37-57

Fumigating Materials 94

Gladiolus ..... 12, 67-68

Gloxinias $\ldots \ldots \ldots \ldots \ldots, 68$

Glass Cleaner .......... 80

Gloriosa $\ldots \ldots \ldots \ldots \ldots, 66$

Grasses .............. $34-36$

Greenhouse Plants .... 61

Grindstones $\ldots \ldots \ldots \ldots .91$

Harrows $\ldots \ldots \ldots \ldots \ldots, 78$

Hedge Trimmer ...... 79

Herbs ........... 30 -31

Horse Boots ........... 83

Hose .............. 72, 80

Hurdles .............. 90

Hyacinths $\ldots \ldots \ldots \ldots \ldots, 68$

Insecticides ........ 94

Ismene ............... 68

Lawn Grass ......... 34-36

Lawn Mowers 83-84-85

Lawn Rollers ........ 86

Lawn Seeder .......... 82

Lawn Sweepers ......... 86

Lawn Sprinklers ..... 87

Lawn Trimmer ....... 85

Lily Bulbs ....... 11, 68

Lily of the Valley... 11, 69

Madera Vine ........ 70

Montbretias ........... 69

Mills, Grinding ........ 79

Nitragin ............... 92

Novelties .........1-11
Page

Oxalis $\ldots \ldots \ldots \ldots \ldots .79$

Palms $\ldots \ldots \ldots \ldots \ldots \ldots, 62$

Paeonies ............ 69

Planet Jr. Tools ... $81-82$

Plows .............. 78

Potatoes .............. 26

Post Hole Digger ... 79

Refuse Burner ........ 80

Rollers ............. 86

Roses ............... 11, 59

Rat Corn ............. 95

Rose Trellis ........ 76,91

Rustic Work ........... 77

Seeders $\ldots . . \ldots \ldots \ldots \ldots .6 \%$

Shading .............. 80

Sod Tampers ........... 91

Spray Pumps...88-89-90

Siweet Peas ....... 55-56

Stakes ............... 73

Tigridias $\ldots \ldots \ldots \ldots \ldots, 69$

Tools ........... 70-76

Tomato Supports ..... 79

Trellis ......... 90-91

Truck and Barrel .... 78

Tubs ............... 80

Tuberoses ........... 69

Vegeta'ble Plants ...... 31

Vegetable Seeds ... 13-30

Violets .............. 61

Watering Pots ........ 76

Weather Vanes ........ 96

Wéed Killers ....... 76, 95

Weeders ............. 76

Zephyranthes ....... 69 
